\title{
ANÁLISE ESTRUTURAL DE LAJES FORMADAS POR ELEMENTOS PRÉ-MOLDADOS TIPO VIGOTA COM ARMAÇÃO TRELIÇADA
}

\section{Eng. Alonso Droppa Júnior}

Dissertação apresentada à Escola de Engenharia de São Carlos da Universidade de São Paulo, como parte dos requisitos para a obtenção do título de Mestre em Engenharia de Estruturas.

ORIENTADOR: Mounir Khalil El Debs

São Carlos

1999 
Class. TESE-EESC

Gutt.

2949

Tombo 0125199

$5 / / S 1034483$

Ficha catalográfica preparada pela Seção de Tratamento da Informação do Serviço de Biblioteca - EESC/USP

D786a

Droppa Júnior, Alonso

Análise estrutural de lajes formadas por elementos pré-moldados tipo vigota com armação treliçada /

Alonso Droppa Júnior. -- São Carlos, 1999.

Dissertação (Mestrado) -- Escola de Engenharia de São Carlos-Universidade de São Paulo, 1999.

Área: Engenharia de Estruturas.

Orientador: Prof. Dr. Mounir Khalil El Debs.

1. Laje pré-moldada. 2. Laje pré-moldada

treliçada. 3. Concreto armado. 4. Analogia da grelha. 5. Comportamento não-linear. I. Título. 
Dissertação defendida e aprovada em 26-03-1999 pela Comissão Julgadora:

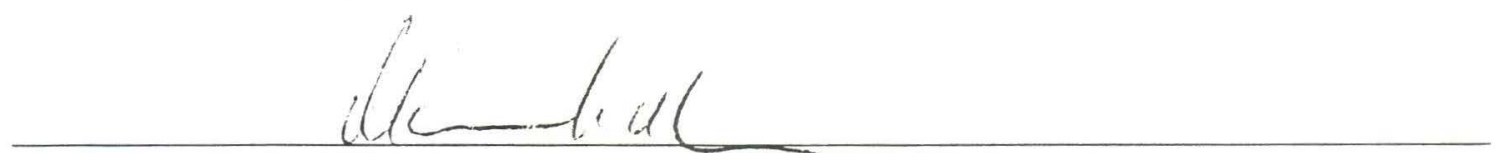

Prof. Associado MOUNIR KHALIL EL DEBS (Orientador)

(Escola de Engenharia de São Carlos - Universidade de São Paulo)

Haicen todert det $\angle$. Prof. Doutor MARCIO ROBERTO SILVA CORRÊA

(Escola de Engenharia de São Carlos - Universidade de São Paulo)

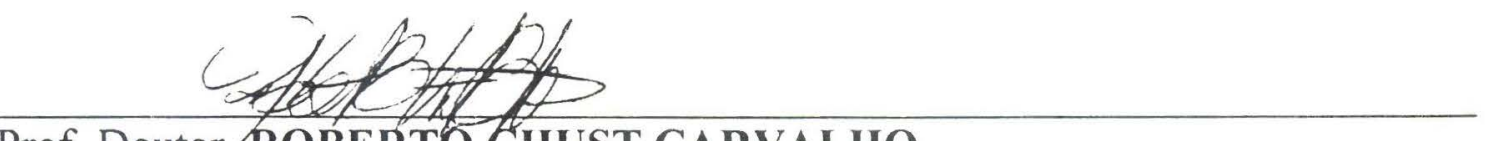

\section{Prof. Doutor ROBERTÓ CHUST CARVALHO}

(Universidáde Federal de São Carlos - UFSCar)

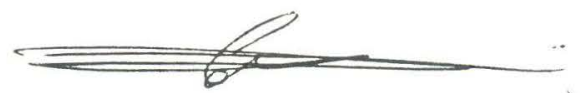

Prof. Titular CARLITO CALIL JUNIOR

Coordenador da Área de Engenharia de Estruturas

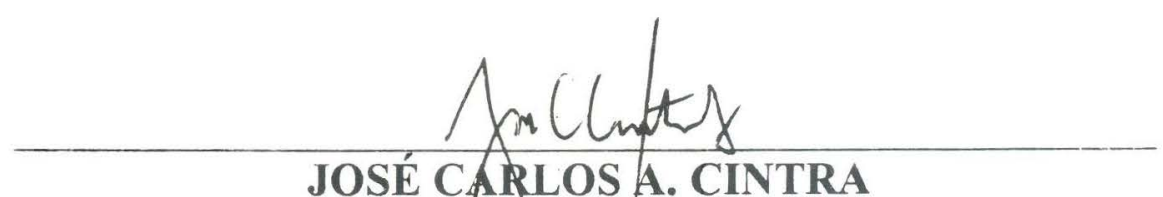

Presidente da Comişão de Pós-Graduação da EESC 
Ao meu pai Alonso Droppa e à minha mãe Emília Sales Carrio Droppa 


\section{AGRADECIMENTOS}

A DEUS, pela sua constante presença.

À minha família que sempre colaborou e acreditou na realização de meus projetos.

Ao prof. Dr. Mounir Khalil El Debs pela sua dedicação, compreensão, respeito, coerência e amizade.

Aos amigos, em especial, Adriano, Joel, Carlos Humberto, Rubens, Francisco Régis, pela convivência neste período.

Aos professores Toshiaki Takeya, Libânio Miranda Pinheiro e Roberto Chust de Carvalho, pelas valiosas contribuições.

A lajes SALEMA, por ter autorizado o uso dos valores experimentais de um ensaio de laje pré-moldada.

Ao Instituto Brasileiro de Tela Soldada, por ter autorizado o uso dos valores experimentais de ensaios em painéis contínuos de laje.

Aos professores do Departamento de Engenharia de Estruturas da Escola de Engenharia de São Carlos.

Aos funcionários do Departamento de Engenharia de Estruturas da Escola de Engenharia de São Carlos, especialmente, Nadir Minatel e Eliana Bertin, pela dedicação e amizade.

Ao CNPq, pelo apoio financeiro concedido. 


\section{SUMÁRIO}

LISTA DE FIGURAS ....................................................................

LISTA DE TABELAS ................................................................. vii

RESUMO

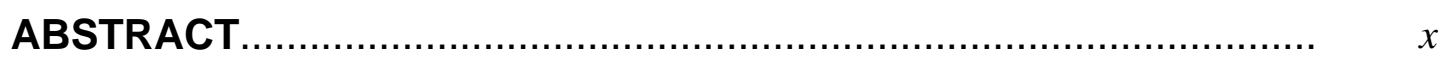

CAPÍTULO 1 INTRODUÇÃO

1.1 CONSIDERAÇÕES INICIAIS.............................................. 1

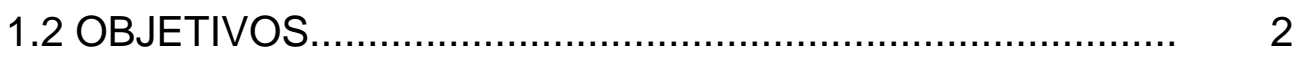

1.3 JUSTIFICATIVAS........................................................ 3

1.4 APRESENTAÇÃO DO TRABALHO ……………….......... 4

CAPÍTULO 2 LAJES FORMADAS POR VIGOTAS PRÉ-MOLDADAS TRELIÇADAS

2.1 CONSIDERAÇÕES INICIAIS............................................ 6

2.2 BREVE HISTÓRICO.......................................................... 7

2.3 LAJES FORMADAS POR VIGOTAS PRÉ-MOLDADAS....... 8

2.4 LAJES FORMADAS POR VIGOTAS PRÉ-MOLDADAS TRELIÇADAS.............................................................. 13

2.5 ANÁLISE ESTRUTURAL E DIMENSIONAMENTO............... 16

\section{CAPÍTULO 3 MÉTODOS E TÉCNICAS}

3.1 CONSIDERAÇÕES INICIAIS............................................ 25

3.2 ANALOGIA DE GRELHA............................................... 26

3.2.1 FUNDAMENTOS GERAIS....................................... 26

3.2.2 PARÂMETROS RELATIVOS À RIGIDEZ À TORÇÃO. $\quad 27$

3.2.3 DISCRETIZAÇÃO DA LAJE PRÉ-MOLDADA............. 31

3.3 CONSIDERAÇÃO DA NÃO-LINEARIDADE........................ 34 
3.4 PROCEDIMENTOS EMPREGADOS PARA CONSIDERAR A NÃO LINEARIDADE...................................................... 38

3.5 PARTICULARIDADES DO PROCEDIMENTO..................... 51

3.5.1 CONTINUIDADE...................................................... 51

3.5.2 CONTRIBUIÇÃO DA CAPA DE CONCRETO............ 53

CAPÍTULO 4 AVALIAÇÃO DO PROCEDIMENTO EMPREGADO PARA A ANÁLISE NÃO-LINEAR

4.1 CONSIDERAÇÕES INICIAIS.............................................. 54

4.2 VIGAS BI-APOIADAS.................................................. 55

4.2.1 DESCRIÇÃO DOS ENSAIOS................................... 55

4.2.2.MODELO ADOTADO E COMPARAÇÕES COM VALORES EXPERIMENTAIS............................... 58

4.2.3 ANÁLISE DOS RESULTADOS................................... 68

4.3 PAINÉIS DE LAJES CONTÍNUAS..................................... 69

4.3.1 DESCRIÇÃO DOS MODELOS ANALISADOS............ 69

4.3.2 MODELO ADOTADO E COMPARAÇÕES COM VALORES EXPERIMENTAIS................................ 73

4.3.3 ANÁLISE DOS RESULTADOS.................................... 77

CAPÍTULO 5 ANÁLISE EXPERIMENTAL DE UMA LAJE PRÉMOLDADA BIDIRECIONAL

5.1 CONSIDERAÇÕES INICIAIS........................................... 78

5.2 ESTRUTURA ANALISADA............................................. 79

5.3 MODELOS ADOTADOS..................................................... 84

5.4 COMPARAÇÃO DE VALORES TEÓRICOS COM

EXPERIMENTAIS ................................................... 86

5.5 ANÁLISE DOS RESULTADOS ........................................ 90

CAPÍTULO 6 SIMULAÇÕES NUMÉRICAS DE SITUAÇÕES REPRESENTATIVAS

6.1 CONSIDERAÇÕES INICIAIS............................................ 92

6.2 MODELOS E ARRANJOS ESTRUTURAIS.......................... 93 
6.3 ANÁLISE TEÓRICA DAS LAJES UNIDIRECIONAIS

MEDIANTE EMPREGO DO MODELO DE GRELHA........... 99

6.3.1 VIGA SIMPLESMENTE APOIADA........................... 99

6.3.2 VIGA CONTÍNUA..................................................... 102

6.3.3 ANÁLISE DOS RESULTADOS................................. 106

6.4 ANÁLISE TEÓRICA DAS LAJES UNIDIRECIONAIS E

BIDIRECIONAIS MEDIANTE O EMPREGO DO MODELO

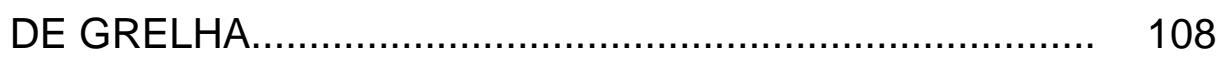

6.4.1 GRELHA ISOLADA............................................ 108

6.4.2 GRELHA ISOLADA COM A CONSIDERAÇÃO DAS VIGAS DE EXTREMIDADE.................................... 122

6.4.3 GRELHA CONTÍNUA ............................................ 128

6.4.4 ANÁLISE DOS RESULTADOS................................. 137

CAPÍTULO 7 - CONSIDERAÇÕES FINAIS E CONCLUSÕES............. 143

ANEXOS

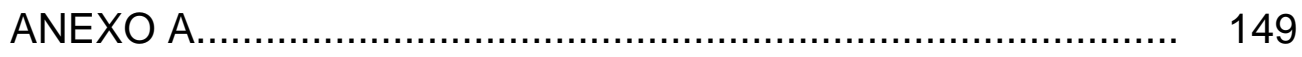

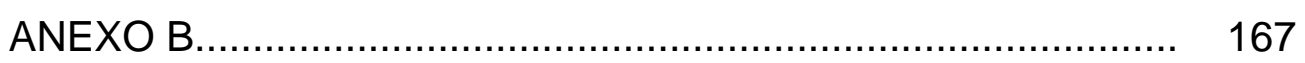

\section{BIBLIOGRAFIA}

REFERÊNCIAS BIBLIOGRÁFICAS........................................ 174

BIBLIOGRAFIA COMPLEMENTAR....................................... 176 


\section{LISTA DE FIGURAS}

Figura 2.1 Sistema Coignet (SEGURADO, 1947) ${ }^{2}$............................. 8

Figura 2.2 Laje formada por vigotas pré-moldadas (BORGES, 1997).. 9

Figura 2.3 Vigotas pré-moldadas disponíveis no mercado brasileiro.... 11

Figura 2.4 Seção da vigota com armadura em forma de treliça e perspectiva da armadura treliçada...................................... 14

Figura 2.5 Laje pré-moldada nervurada, painel maciço e painel c/ enchimento............................................................ 15

Figura 2.6 Dimensões principais - seção da laje treliçada.................... 16

Figura 2.7 Largura da mesa de compressão....................................... 20

Figura 2.8 Dimensionamento da nervura - mesa comprimida e tracionada.................................................................... 24

Figura 3.1 Laje e grelha equivalente. Fonte HAMBLY (1991).............. 26

Figura 3.2 Área de influência para determinação do carregamento em um nó genérico (i)..................................................... 27

Figura 3.3 Seção transversal homogênea retangular.................................... 29

Figura 3.4 Seção I - Cálculo do momento de inércia à torção, segundo LEONHARDT (1979).

Figura 3.5 Seção I - Cálculo do momento de inércia à torção, segundo BARES (1966).

Figura 3.6 Esquema de um painel de laje apoiado em vigas................... 31

Figura 3.7 Seção da nervura que contém a vigota pré-moldada........ 32

Figura 3.8 Localização das barras da grelha na direção longitudinal às vigotas (dimensões em $\mathrm{cm}$ )

Figura 3.9 Localização das barras da grelha na direção transversal às vigotas (dimensões em $\mathrm{cm}$ )......................................... 33

Figura 3.10 Malha da grelha.......................................................... 33

Figura 3.11 Momento fletor $x$ curvatura segundo o CEB-90 (1991)..... 36

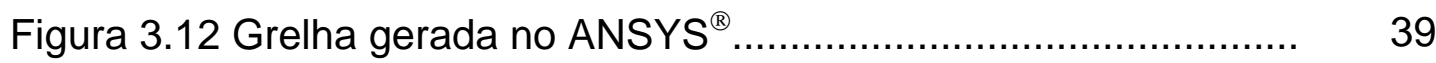


Figura 3.13 Viga bi-apoiada discretizada em 5 elementos.................... 41

Figura 3.14 Diagrama tensão $x$ deformação - concreto e aço.............. $\quad 45$

Figura 3.15 Momento de inércia - estádio I e II.................................. 46

Figura 3.16 Variação da rigidez à flexão........................................... 46

Figura 3.17 Variação da rigidez à torção........................................... 48

Figura 3.18 Diagrama genérico de carga $x$ deslocamento................... $\quad 49$

Figura 3.19 Fluxograma da análise não-linear................................... 50

Figura 3.20 Diagrama de momento fletor para lajes simplesmente apoiadas e lajes contínuas............................................. 51

Figura 3.21 Dimensionamento da nervura - mesa comprimida e Tracionada.............................................................. 52

Figura 3.22 Análise não-linear - momento fletor positivo e negativo.... $\quad 52$

Figura 3.23 Contribuição da capa de concreto na direção transversal.. 53

Figura 4.1 Esquema de ensaio da viga "I" e instrumentação dimensões em $\mathrm{cm}$...

Figura 4.2 Seção transversal da viga "I" e instrumentação dimensões em $\mathrm{cm}$.

Figura 4.3 Esquema do ensaio das vigas com seção retangular.. 57

Figura 4.4 Seção transversal das vigas - dimensões em cm............... 58

Figura 4.5 Divisão da viga "I" em elementos...................................... 59

Figura 4.6 Determinação da curvatura média....................................... 61

Figura 4.7 Força aplicada x curvatura - viga A.1 …......................... 64

Figura 4.8 Rigidez x força aplicada - viga A.1................................... 64

Figura 4.9 Força aplicada $x$ deslocamento - viga A.1 ....................... 64

Figura 4.10 Força aplicada x curvatura - viga A.2........................... 65

Figura 4.11 Rigidez x força aplicada - viga A.2............................... $\quad 65$

Figura 4.12 Força aplicada $x$ deslocamento - viga A.2..................... 65

Figura 4.13 Força aplicada $x$ deslocamento - viga B.1

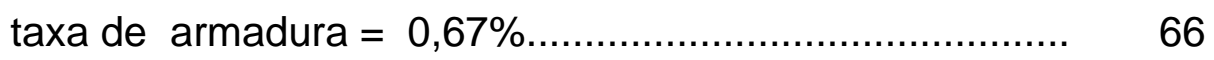

Figura 4.14 Força aplicada $x$ deslocamento - viga B.2 taxa de armadura $=1,11 \%$. 
Figura 4.15 Força aplicada $x$ deslocamento - viga B.3

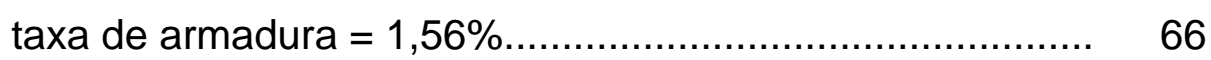

Figura 4.16 Força aplicada x curvatura - vigas B.1, B.2 e B.3.............. 67

Figura 4.17 Diagrama Rigidez x força aplicada - vigas B.1, B.2 e B.3... 67

Figura 4.18 Planta de forma da placa - dimensões em $\mathrm{cm}$.................... $\quad 70$

Figura 4.19 Armação dos painéis com telas soldadas........................... $\quad 70$

Figura 4.20 Esquema do ensaio - dimensões em cm........................... 71

Figura 4.21 Força aplicada $x$ deslocamento - série 1.......................... $\quad 74$

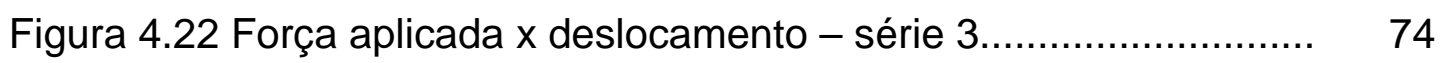

Figura 4.23 Força aplicada $x$ deslocamento - série 5 .......................... $\quad 75$

Figura 4.24 Força aplicada $x$ deslocamento - série 7......................... 75

Figura 4.25 Força aplicada $x$ deslocamento - série 9......................... $\quad 75$

Figura 4.26 Força aplicada $x$ deslocamento - série 11........................ 76

Figura 4.27 Força aplicada $x$ momento fletor máximo - série 5 - $\beta_{b}=0,4 . \quad 76$

Figura 4.28 Rigidez x força aplicada - série $5-\beta_{b}=0,4 \ldots \ldots \ldots \ldots \ldots \ldots \ldots \ldots . . \quad 76$

Figura 5.1 Perspectiva da laje - FRANCA (1997)................................ $\quad 79$

Figura 5.2 Vista da laje antes da concretagem................................... 81

Figura 5.3 Vista geral do protótipo e do suporte de madeira utilizado para o carregamento com água........................................ 81

Figura 5.4 Laje com o carregamento máximo........................................ 82

Figura 5.5 Posicionamento dos defletômetros....................................... 82

Figura 5.6 Localização das nervuras (dimensões em cm)...................... 83

Figura 5.7 Seções transversais das nervuras (dimensões em $\mathrm{cm}$ )......... 83

Figura 5.8 Malha da grelha........................................................ $\quad 85$

Figura 5.9 Diagrama de Sobrecarga $x$ deslocamento............................ 87

Figura 5.11 Diagrama de momento fletor para a sobrecarga de $6,0 \mathrm{kN} / \mathrm{m}^{2}$.

Figura 5.11 Diagrama rigidez à flexão $x$ carregamento da seção transversal da nervura longitudinal mais solicitada ao momento fletor. 
Figura 6.1 Seção transversal das nervuras longitudinais e da vigota

Pré-moldada - dimensões em cm.

Figura 6.2 Seção transversal das barras transversais - dimensões

em $\mathrm{cm}$

Figura 6.3 Formato das lajes em planta.

Figura 6.4 Carregamento $\mathrm{x}$ deslocamento - nervura simplesmente apoiada $-\mathrm{h}=12 \mathrm{~cm}$

Figura 6.5 Carregamento $\mathrm{x}$ deslocamento - nervura simplesmente apoiada $-\mathrm{h}=20 \mathrm{~cm}$.

Figura 6.6 Diagrama de momento fletor determinado em regime elástico linear e diagramas obtidos com a redução do momento fletor negativo.

Figura 6.7 Carregamento x deslocamento -nevura contínua - $\mathrm{h}=12 \mathrm{e}$ $20 \mathrm{~cm}$.

Figura 6.8 Variação do máximo momento fletor negativo laje $\mathrm{h}=12 \mathrm{~cm}$ - análise não-linear.

Figura 6.9 Variação do máximo momento fletor negativo laje $\mathrm{h}=20 \mathrm{~cm}$ - análise não-linear. 105

Figura 6.10 Grelha e os elementos constituintes - laje nervurada unidirecional. 108

Figura 6.11 Diagrama de momento fletor $-\mathrm{h}=12 \mathrm{~cm}$. 109

Figura 6.12 Diagrama de Momento Fletor $-\mathrm{h}=20 \mathrm{~cm}$. 109

Figura 6.13 Variação do máximo momento fletor na nervura longitudinal em função da rigidez da nervura transversal $-\mathrm{h}=12 \mathrm{~cm}$.

Figura 6.14 Variação do máximo momento fletor na nervura longitudinal em função da rigidez da nervura transversal $-\mathrm{h}=20 \mathrm{~cm}$.

Figura 6.15 Diagrama de momento fletor- inércia à flexão transversal igual a $0 \%$ da inércia à flexão longitudinal.

Figura 6.16 Diagrama de momento fletor- inércia à flexão transversal igual a $10 \%$ da inércia à flexão longitudinal. 
Figura 6.17 Diagrama de momento fletor- inércia à flexão transversal igual a $50 \%$ da inércia à flexão longitudinal.

Figura 6.18 Diagrama de momento fletor- inércia à flexão transversal igual a $100 \%$ da inércia à flexão longitudinal.

Figura 6.19 Contribuição da capa de concreto na direção transversal.... 114

Figura 6.20 Nervuras transversais "nervura de travamento"

da laje unidirecional.

Figura 6.21 Carregamento x máximo momento fletor $-\mathrm{h}=12 \mathrm{~cm}$. 118

Figura 6.22 Carregamento x máximo momento fletor $-\mathrm{h}=20 \mathrm{~cm}$. 118

Figura 6.23 Carregamento $x$ deslocamento $-\mathrm{h}=12 \mathrm{~cm} \quad(6,0 \mathrm{~m} \times 6,0 \mathrm{~m})$..

Figura 6.24 Carregamento $x$ deslocamento $-\mathrm{h}=12 \mathrm{~cm} \quad(12,0 \mathrm{~m} \times 6,0 \mathrm{~m}) 119$

Figura 6.25 Carregamento $x$ deslocamento $-\mathrm{h}=20 \mathrm{~cm} \quad(6,0 \mathrm{~m} \times 6,0 \mathrm{~m}) . . \quad 120$

Figura 6.26 Carregamento $x$ deslocamento - $\mathrm{h}=20 \mathrm{~cm}(12,0 \mathrm{~m} \times 6,0 \mathrm{~m}) \quad 120$

Figura 6.27 Reação de apoio das nervuras longitudinais

$(6 \mathrm{~m} \times 6 \mathrm{~m}$ e $12 \mathrm{~m} \times 6 \mathrm{~m})$.

Figura 6.28 Grelha com vigas de extremidade. 122

Figura 6.29 Momento fletor negativo. 123

Figura 6.30 Carregamento x máximo momento fletor negativo laje unidirecional $-\mathrm{h}=12 \mathrm{~cm}$. 125

Figura 6.31 Carregamento x máximo momento fletor negativo laje unidirecional - $\mathrm{h}=20 \mathrm{~cm}$. 126

Figura 6.32 Carregamento $x$ deslocamento laje unidirecional $-\mathrm{h}=12 \mathrm{~cm}$ 126

Figura 6.33 Carregamento $x$ deslocamento laje bidirecional $-\mathrm{h}=12 \mathrm{~cm}$ 127

Figura 6.34 Carregamento $x$ deslocamento laje unidirecional $-\mathrm{h}=20 \mathrm{~cm}$ 127

Figura 6.35 Carregamento $x$ deslocamento laje bidirecional $-\mathrm{h}=20 \mathrm{~cm}$ 128

Figura 6.36 Grelha contínua. 129

Figura 6.37 Diagrama de momento fletor - grelha contínua unidirecional. 130

Figura 6.38 Diagrama de momento fletor - laje unidirecional - $h=12 \mathrm{~cm} \quad 130$

Figura 6.39 Diagrama de momento fletor - laje unidirecional $-\mathrm{h}=20 \mathrm{~cm} \quad 131$

Figura 6.40 Variação do máximo momento fletor negativo - $\mathrm{h}=12 \mathrm{~cm}$.. 132

Figura 6.41 Variação do máximo momento fletor negativo - $\mathrm{h}=20 \mathrm{~cm}$.. 132 
Figura 6.42 Carregamento $x$ deslocamento -grelha contínua - $\mathrm{h}=12 \mathrm{~cm} \quad 133$

Figura 6.43 Carregamento $x$ deslocamento -grelha contínua - $\mathrm{h}=20 \mathrm{~cm} \quad 134$

Figura 6.44 Laje unidirecional contínua - disposição das vigotas pré-moldadas em direções opostas................................ 134

Figura 6.45 Diagrama de momento fletor - grelha contínua - h = $12 \mathrm{~cm} 135$

Figura 6.46 Diagrama de momento fletor - grelha contínua $-\mathrm{h}=20 \mathrm{~cm} \quad 135$

Figura A.1 Diagrama tensão-deformação do concreto....................... 150

Figura A.2 Diagrama tensão-deformação do aço classe A................... 151

Figura A.3 Diagrama tensão-deformação do aço classe B................... 151

Figura A.4 Escoamento ou plastificação - seção retangular................... 152

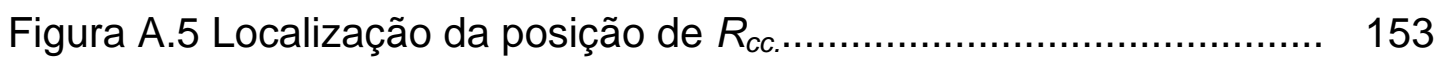

Figura A.6 Escoamento ou plastificação - seção "T".......................... 154

Figura A.7 Determinação da resultante do concreto para seção “T”...... 154

Figura A.8 Sub-domínio 2a..................................................... 159

Figura A.9 Sub-domínio 2b...................................................... 161

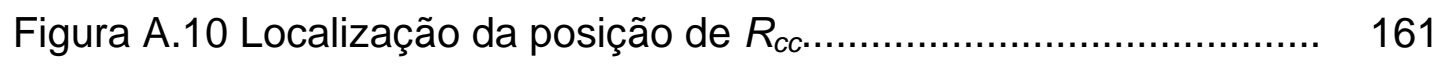

Figura A.11 Localização da posição de $R_{c c f \ldots \ldots \ldots \ldots \ldots \ldots \ldots \ldots \ldots \ldots \ldots \ldots \ldots . . . \ldots \ldots \ldots} 162$

Figura A.12 Domínio 3............................................................. 163

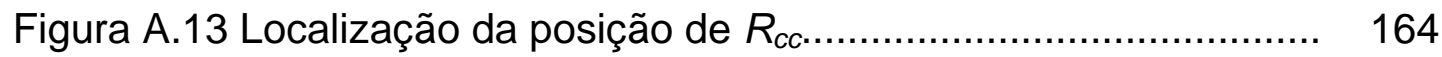

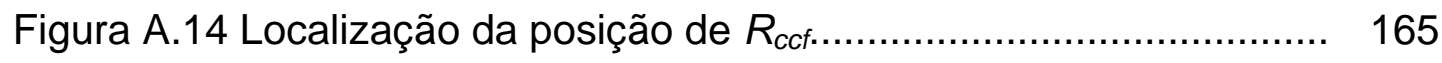

Figura A.15 Domínio 4............................................................ 165

Figura B.1 Seção transversal da viga e da nervura........................... 168

Figura B.2 Diagrama tensão x deformação do concreto e do aço.......... 168

Figura B.3 Taxa de armadura x rigidez à flexão viga com aço CA-50.................................................. 170

Figura B.4 Taxa de armadura x rigidez à flexão nervura com aço C-60. 


\section{LISTA DE TABELAS}

Tabela 2.1 Tipos mais usuais de treliças............................................ 13

Tabela 4.1 Características geométricas e mecânicas - viga "I"............. 60

Tabela 4.2 Características geométricas e mecânicas - viga retangular $\quad 63$

Tabela 4.3 Numeração das séries e variáveis envolvidas.................... $\quad 72$

Tabela 4.4 Características geométricas e mecânicas dos elementos submetidos ao momento fletor positivo............................. $\quad 72$

Tabela 4.5 Características geométricas e mecânicas dos elementos submetidos ao momento fletor negativo............................ $\quad 73$

Tabela 5.1 Valores das características geométricas e mecânicas........ 84

Tabela 5.2 Valores de máximo momento fletor - peso próprio +

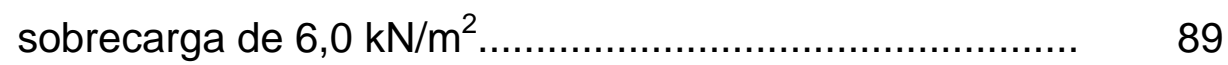

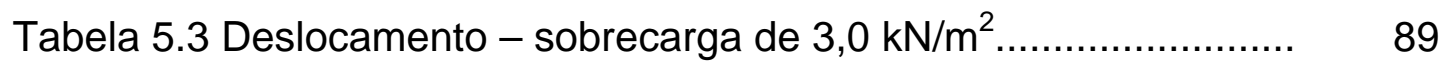

Tabela 6.1 Modelos e arranjos estruturais......................................... 93

Tabela 6.2 Peso próprio e carregamento total $\left(\mathrm{kN} / \mathrm{m}^{2}\right) \ldots \ldots \ldots \ldots \ldots \ldots \ldots \ldots . . . . . . . . . . \quad 97$

Tabela 6.3 Máximo momento fletor e área de aço............................... $\quad 99$

Tabela 6.4 Características geométricas e mecânicas das nervuras..... 100

Tabela 6.5 Características geométricas e mecânicas da nervura Contínua.................................................................. 103

Tabela 6.6 Relação entre o momento fletor negativo (análise linear) e momento fletor negativo (análise não-linear)................. 105

Tabela 6.7 Nervura transversal - momento fletor e dimensionamento.. $\quad 115$

Tabela 6.8 Máximo momento fletor e área de aço da laje bidirecional.. 116

Tabela 6.9 Momento fletor calculado segundo BARES, e comparação com valores obtidos pela grelha bidirecional..................... 116

Tabela 6.10 Momento fletor utilizado para o dimensionamento e o obtido pela análise não linear - nervura longitudinal $\mathrm{h}=12 \mathrm{~cm}$. 
Tabela 6.11 Momento fletor utilizado para o dimensionamento e o obtido pela análise não linear - nervura longitudinal.......

Tabela 6.12 Reação de apoio das nervuras longitudinais - Parcela (\%) do carregamento.

Tabela 6.13 Máximo momento fletor negativo nas nervuras da laje (kN.cm)

Tabela 6.14 Dimensionamento das nervuras submetidas ao momento fletor negativo.

Tabela 6.15 Relação do momento negativo obtido pela análise não linear pelo momento negativo considerado para o dimensionamento da seção.

Tabela 6.16 Flecha nas lajes com altura igual a $12 \mathrm{~cm}$ 136

Tabela 6.17 Flecha nas lajes com altura igual a $12 \mathrm{~cm}$

Tabela B.1 Características geométricas e mecânicas da viga retangular.

Tabela B.2 Características geométricas e mecânicas da nervura 


\section{RESUMO}

DROPPA, Jr. A. (1999). Análise estrutural de lajes formadas por elementos pré-moldados tipo vigota com armação treliçada. São Carlos. Dissertação (mestrado) - Escola de Engenharia de São Carlos, Universidade de São Paulo.

Neste trabalho é enfocada a análise estrutural de lajes pré-moldadas formadas por vigotas treliçadas. Esta análise foi realizada mediante o modelo de grelha, considerando a não-linearidade do concreto armado utilizando-se a relação momento x curvatura e carregamento incremental.

O modelo da não-linearidade do concreto armado foi avaliado com resultados experimentais de vigas bi-apoiadas e painéis de laje contínua. $\mathrm{O}$ trabalho inclui uma análise teórico-experimental de uma laje pré-moldada bidirecional isolada e simulações numéricas de casos representativos de arranjos estruturais das lajes treliçadas.

As principais conclusões do trabalho foram: a) o modelo de grelha é bastante adequado para a análise de lajes nervuradas pré-moldadas; b) os resultados da análise teórico-experimental da laje pré-moldada indicam que os deslocamentos foram fortemente influenciados pela rigidez à torção e c) a redistribuição de momentos fletores nas lajes contínuas é relativamente pequena.

Palavras chave: Laje pré-moldada, laje pré-moldada treliçada, concreto armado, analogia de grelha, comportamento não-linear. 


\section{ABSTRACT}

DROPPA, Jr. A. (1999). Structural analysis of slabs made by precast elements type lattice joist. São Carlos. Dissertation (master's degree) Escola de Engenharia de São Carlos, Universidade de São Paulo.

This work aims the structural analysis in precast slabs made by lattice joist. The scheme was carried out by using the grillage model considering the non-linear of the reinforced concrete through the relationship moment $x$ curvature and incremental loads. The non-linear model of the reinforced concrete was appraised with experimental of simply supported beams and panels of continuos slabs.

The work includes a theoretical-experimental analysis of a isolated bidirectional precast slabs and numeric simulations of representative cases of structural arrangements of the slabs witch lattice joist.

The main conclusions of the work were: a) the grillage model is quite appropriate for precast ribbed slabs; b) the results of theoretical-experimental analysis of the precast slabs point out the relevance the torsional in the deflections and $\mathrm{c}$ ) the bending moments redistribution in the continuous slabs are quite small.

Key words: Precast slabs, precast slabs witch lattice joist, reinforced concrete, grillage model, non-linear behavior. 


\section{INTRODUÇÃO}

\subsection{CONSIDERAÇÕES INICIAIS}

A concepção estrutural de pavimentos com grandes vãos é uma tendência atual, sendo que em muitos casos são dispostas paredes de alvenaria sob a laje.

Com a utilização de lajes maciças nesses pavimentos observa-se que estas lajes atingem espessuras muito grandes, tornando a estrutura antieconômica, pois uma grande parte de sua capacidade estrutural é para combater as solicitações devidas ao peso próprio.

Uma solução é o emprego da laje nervurada, sendo um sistema estrutural que permite vãos maiores e um alívio do peso próprio. $O$ grande problema deste sistema é relacionado com as fôrmas, ou seja, necessita-se de maior volume de mão-de-obra para a confecção e montagem das fôrmas e escoramentos, e também o custo dos materiais.

Com a execução de lajes nervuradas a partir de vigotas prémoldadas, elementos de enchimento e concreto moldado no local, reduz-se ou elimina-se a necessidade de fôrmas e escoramentos.

Estas lajes foram disseminadas por inúmeras pequenas empresas produtoras, muito até informais. Algumas empresas pecam pela falta de qualidade e responsabilidade, muitas vezes comprometendo até a 
segurança, aparecendo problemas estruturais devidos a grandes deformações, fissurações e até mesmo o risco de desabamento.

Entretanto, surgiram novas técnicas e materiais constituintes para as lajes pré-moldadas. Empresas do setor desenvolveram e implementaram novos sistemas do uso destas lajes. É o caso dos sistemas de lajes com vigotas de concreto protendido e as lajes formadas pelas vigotas com armação em forma de treliça (vigotas treliçadas), que asseguram uma alternativa de grande competitividade às construções.

De acordo com os dados da Abilaje (Associação Brasileira da Indústria de Lajes) - Fonte: LAJES DO FUTURO (1998) ${ }^{\mathbf{1}}$, em 1990 as lajes formadas por vigotas treliçadas detinham uma participação no mercado de apenas 5\%, em 1998 saltou para 40\%. Acompanhando esse crescimento, observa-se a necessidade de ampliação do conhecimento técnico sobre essas lajes, em especial com relação às deformações, que podem inviabilizar as suas condições de serviço.

\subsection{OBJETIVOS}

\section{Objetivo geral}

Contribuir para uma melhor avaliação do comportamento das lajes nervuradas formadas por vigotas pré-moldadas com armadura treliçada

\footnotetext{
${ }^{1}$ A referência bibliográfica é indicada em negrito, sendo apresentado o autor, nome do artigo ou norma, seguido pela data de publicação, neste caso tem-se o nome do artigo: LAJES DO FUTURO (1998).
} 


\section{Objetivos específicos}

a) Realizar estudos teóricos mediante simulações em programas de computador, sendo o estudo dirigido a painéis de laje unidirecionais e bidirecionais;

b) Propor recomendações para a análise deste tipo de laje.

\subsection{JUSTIFICATIVAS}

Nos edifícios, as lajes são responsáveis por elevada parcela do consumo de concreto. Torna-se oportuno o estudo dos critérios de escolha dos tipos de laje a serem empregados nos edifícios, tendo em vista a obtenção de soluções tecnicamente corretas e econômicas.

As lajes pré-moldadas estão sendo amplamente utilizadas nas edificações. Em contrapartida, há poucas informações técnicas a respeito do comportamento dessas lajes, como por exemplo: a distribuição do carregamento da laje nas vigas (reações de apoio ), a estimativa segura ou mais realista da flecha, o comportamento da continuidade entre painéis, as fissuras que ocorrem próximas aos apoios e na direção longitudinal acompanhando a interface da vigota e o elemento de enchimento. Estas incertezas justificam o desenvolvimento de estudos objetivando um melhor entendimento do seu comportamento estrutural.

Durante a análise e/ou dimensionamento de pavimentos, tem-se 0 cálculo dos esforços atuantes nos elementos (lajes, vigas, pilares). Sendo fundamental para a determinação e disposição das armaduras e também o controle da fissuração. Geralmente a análise é realizada pelo procedimento tradicional, calculando-se as lajes como elementos independentes e, depois, efetuando-se o cálculo das vigas e dos pilares. 
A utilização destas análises conduz a resultados muito simplificados, uma vez que compromete a interação entre a rigidez dos diversos elementos estruturais.

Com a evolução e melhor acessibilidade aos programas estruturais para micro-computadores, o cálculo de pavimentos utilizando métodos numéricos tornou-se indispensável, sendo os mais conhecidos: método dos elementos finitos, da analogia de grelha e das diferenças finitas. Estes métodos conduzem a melhores resultados devido à maior interação entre os elementos estruturais do pavimento. Nestes métodos, torna-se possível o estudo do comportamento não-linear dos elementos constituintes da estrutura.

O estudo deste crescente sistema construtivo de pavimentos com elementos pré-moldados, torna-se aliado às evoluções computacionais. No que diz respeito aos processamentos numéricos da estrutura e também à facilidade de lançamento dos dados de geometria e carregamento da estrutura e análise dos resultados através da inovação dos pré e pósprocessadores.

\subsection{APRESENTAÇÃO DO TRABALHO}

Esta dissertação é dividida em 7 capítulos. Apresenta-se a seguir, sucintamente o conteúdo dos capítulos:

No capitulo 2, apresentam-se informações da bibliografia pesquisada,. sendo referentes às características gerais das lajes pré-moldadas, enfatizando as lajes pré-moldadas com vigotas treliçadas;

No capítulo 3, mostra-se a metodologia utilizada para 0 desenvolvimento das análises teóricas;

No capítulo 4, são apresentadas comparações teórico-experimentais em elementos unidirecionais de modo a avaliar o procedimento teórico adotado; 
No capítulo 5, apresenta-se a análise teórico-experimental em uma laje bidirecional;

No capítulo 6, desenvolvem-se análises teóricas em lajes prémoldadas, considerando-se vários arranjos estruturais;

No capítulo 7, são apresentadas as conclusões e comentadas as sugestões para o desenvolvimento de futuras pesquisas. 


\section{LAJES FORMADAS POR VIGOTAS PRÉ-MOLDADAS TRELIÇADAS}

\subsection{CONSIDERAÇÕES INICIAIS}

A grande vantagem da utilização das lajes pré-moldadas é a redução da quantidade de fôrmas, em relação à laje maciça ou à laje nervurada moldada no local. E aliada a suas características geométricas, há redução do volume de concreto e armadura, se comparado às lajes maciças.

Estes fatores propiciam maior economia de materiais e tempo de execução, sendo, por isso, um sistema que está sendo cada vez mais empregado.

Com o aumento da demanda dessas lajes, novos tipos de laje prémoldada foram desenvolvidos, como por exemplo as lajes nervuradas prémoldadas formadas por vigotas com armação em forma de treliça, comumente chamadas de laje treliçada.

Neste capítulo apresentam-se as lajes pré-moldadas, enfatizando as características das lajes treliçadas e critérios para a análise estrutural e o dimensionamento. 


\subsection{BREVE HISTÓRICO}

A arte de projetar e construir sempre foi e será um desafio ao homem. Um dos maiores desafios na história das construções era o de vencer vãos e suportar cargas.

De início, utilizavam-se os materiais naturais como a madeira e a pedra. As pedras eram cortadas e adaptadas a seus apoios e a madeira era limitada às suas dimensões naturais.

Os arcos de pedra foram uma evolução importante. Muito utilizados durante o Império Romano, permitiam vencer maiores vãos, tornando os espaços internos ficaram mais amplos. A técnica dos arcos apresentava as características peculiares de desenvolverem somente esforços de compressão.

A construção de arcos e abóbadas, com alvenaria de cerâmica e argamassa de cal foi difundida até meados do século XIX.

Surge na França, na segunda metade do século XIX por François Coignet (1812-1895) um trabalho sobre o cimento armado (primeira atribuição dada ao concreto-armado), com destaque para as lajes nervuradas e armadas com barras de aço com seção transversal circular (figura 2.1).

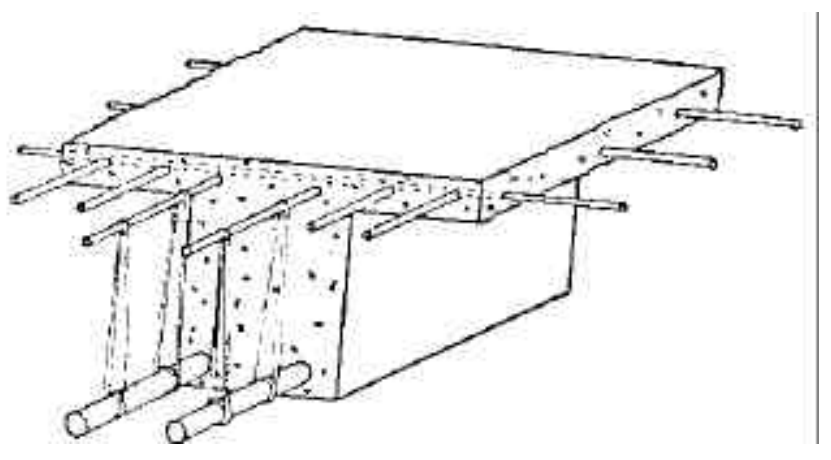

Fig.2.1 - Sistema Coignet (SEGURADO, 1947) ${ }^{2}$

2 (SEGURADO, J. E. S. , 1947). Cimento armado. Portugal. Aillaud apud BORGES (1997). 
Baseado neste sistema francês, os alemães começam a desenvolver o sistema de lajes pré-moldadas, formadas por vigotas pré-moldadas de concreto armado, blocos de alvenaria como elementos de enchimento e pela capa de argamassa formada por cimento e areia.

De acordo com BORGES (1997), é provável que os precursores da aplicação das lajes pré-moldadas no Brasil, tenham sido as indústrias de pré-moldados do Rio de Janeiro na década de 40.

Segundo MUNIZ (1991), o sistema de lajes treliçadas surgiu e teve larga utilização a partir da Segunda Guerra Mundial. Foi criado para superar algumas deficiências que as lajes pré-moldadas convencionais apresentavam, e em muito contribuiu para solucionar o problema da reconstrução dos países destruídos pela guerra, e a grave crise habitacional conseqüente. Hoje estas lajes respondem pela maior fatia entre as opções de pavimentos, sobretudo em obras na Itália e na Espanha.

A partir da década de 60, começou-se a produzir em escala industrial na Europa armaduras pré-fabricadas soldadas por eletrofusão para utilização na indústria da construção civil. Nos dias de hoje, estas armaduras são bastante utilizadas em todo o mundo, tendo a função tanto de armadura de distribuição como a de resistente a esforços solicitantes. Como exemplo, pode-se citar a tela soldada e a armadura treliçada.

No Brasil, as lajes treliçadas já são utilizadas há cerca de 25 anos, mas sua difusão e seu crescimento se deram no início da década de 90. Hoje, muitas fábricas de lajes oferecem as mais variadas opções de executar a laje treliçada, podendo ser lajes nervuradas unidirecionais ou bidirecionais.

\subsection{LAJES FORMADAS POR VIGOTAS PRÉ-MOLDADAS}

As lajes pré-moldadas são aquelas que possuem a seção resistente composta pela parte pré-moldada e, se houver, pelo concreto moldado no local. 
As lajes formadas por vigotas pré-moldadas (figura 2.2), em função de sua geometria, é considerada uma laje nervurada, e apesar do grande volume de concreto moldado no local, são caracterizadas como lajes prémoldadas, portanto, laje pré-moldada nervurada. Este sistema mantém a vantagem principal dos pré-moldados, que é a redução da quantidade de fôrmas e escoramentos se comparados a um sistema convencional. Neste trabalho, o estudo é dirigido às lajes nervuradas formadas por vigotas prémoldadas, que a partir de agora, são designadas apenas por lajes prémoldadas.

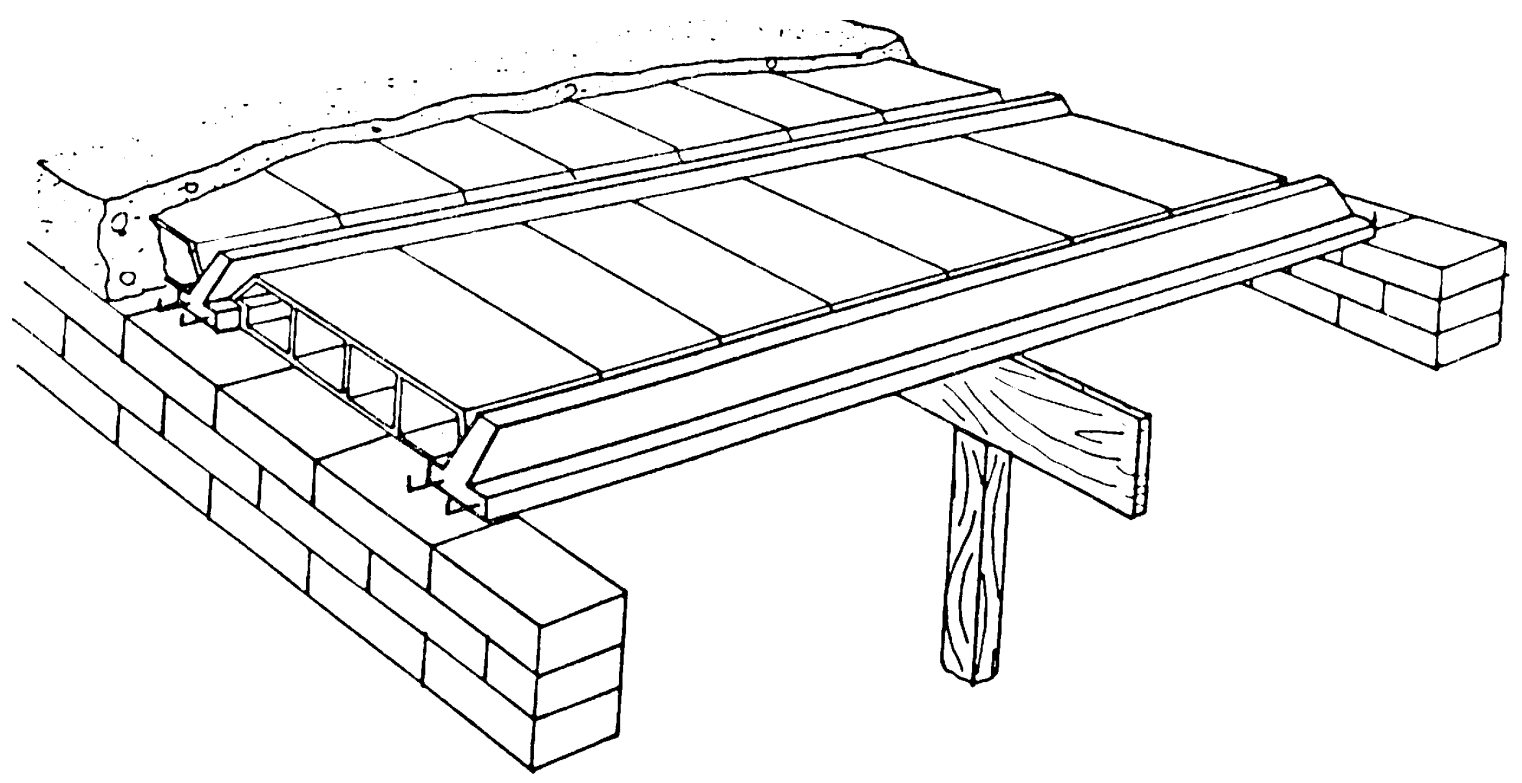

Fig.2.2 Laje formada por vigotas pré-moldadas (BORGES, 1997)

As lajes pré-moldadas são executadas em praticamente todas as cidades brasileiras, pois é possível fabricá-las quase que artesanalmente. Além destas pequenas fábricas, há também algumas de porte, que dominam este mercado nos grandes centros, sendo grandes e médias empresas dirigidas por engenheiros com especialização nessa área, ou pelo menos, orientadas por fabricantes e distribuidores.

Além da aplicação destas lajes em obras residenciais, em edificações de poucos pavimentos, deve-se destacar, no entanto, que recentemente 
estes tipos de laje têm avançado rumo aos edifícios de mais pavimentos, substituindo até mesmo as lajes maciças dos edifícios.

As vigotas pré-moldadas devem ser capazes de suportar seu peso próprio e as cargas de construção, vencendo os vãos delimitados pelas linhas de apoio do cimbramento. Presentemente, no mercado brasileiro (figura 2.3), estão disponíveis três tipos de vigotas:

1- vigotas de concreto armado comum, não protendido, com seção transversal com a forma aproximada de um $\mathrm{T}$ invertido, com armadura passiva totalmente envolvida pelo concreto;

2- vigotas de concreto protendido, com seção transversal com a forma aproximada de um $\mathrm{T}$ invertido, com armadura de protensão prétracionada e totalmente envolvida pelo concreto;

3- vigotas treliçadas, formadas por uma armadura treliçada de aço e por uma placa de concreto envolvendo as barras inferiores da treliça que irão compor a armadura da face tracionada da laje.

As vigotas são fabricadas no tamanho desejado do projeto, sendo normalmente usadas para vencer vãos de até 5 metros no caso das lajes de concreto armado comumente chamada de Volterrana e da ordem de 10 metros ou mais nas lajes protendidas e treliçadas. Sem dúvida, com a utilização das lajes protendidas e treliçadas consegue-se vencer grandes vãos, mas deve-se, portanto, ser feita uma análise criteriosa em casos de considerações de vãos muito grandes, principalmente no que diz respeito à deformação da laje e o efeito da força cortante que é grande.

As vigotas pré-moldadas de concreto armado são executadas em fôrmas metálicas, em pequenas unidades de produção, com instalações físicas simples. As vigotas de concreto protendido são executadas em pistas de protensão em fôrmas fixas ou com fôrmas deslizantes, de forma similar ao das lajes alveolares.

A base retangular pré-moldada de concreto da vigota treliçada é moldada em fôrma metálica, em espessuras de 2 a $3 \mathrm{~cm}$, empregando-se 
concreto com agregado miúdo, denominado de microconcreto - concreto cujo agregrado de diâmetro máximo é a brita zero e rico em pasta de cimento, para se evitar a necessidade de vibração.

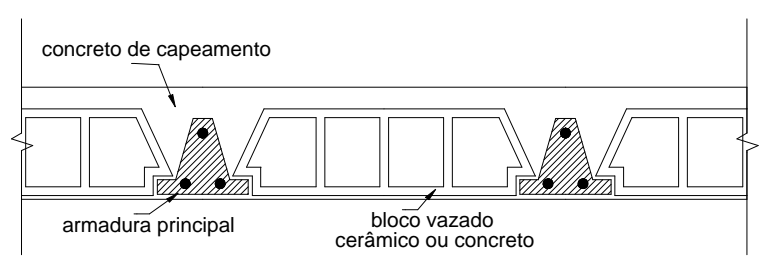

vigota de concreto armado comum

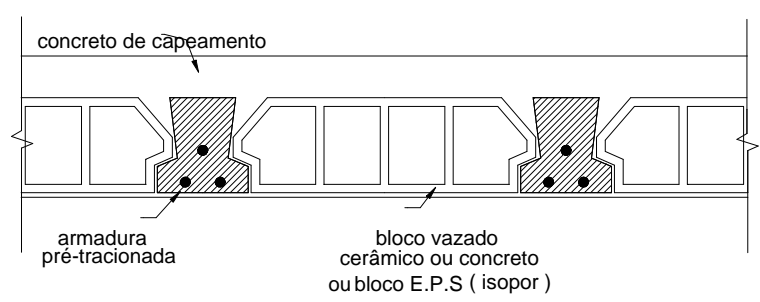

vigota de concreto armado protendido

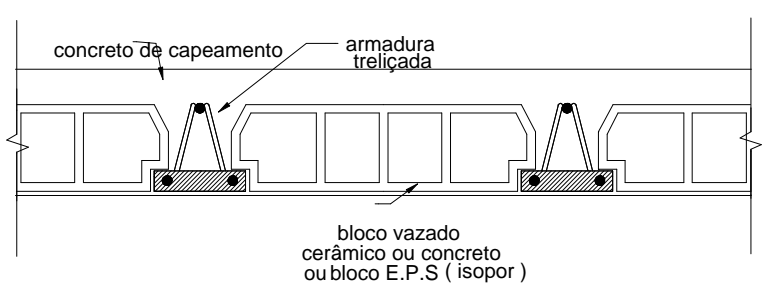

vigota com armadura treliçada

Fig.2.3 Vigotas pré-moldadas disponíveis no mercado brasileiro

$\mathrm{Na}$ montagem ou execução da laje, as vigotas são dispostas espaçadamente, colocados entre elas elementos leves de enchimento. Sendo normalmente utilizados blocos vazados de concreto ou material cerâmico, ou ainda blocos de poliestireno expandido (EPS). A utilização de elementos de material leve está ligada à idéia de substituir parte do concreto da região tracionada das lajes, bem como servir de sustentação à camada de concreto fresco que é aplicada sobre os painéis das lajes pré-fabricadas. 
As principais vantagens das lajes pré-moldadas são:

- economizar fôrmas e escoramentos na obra, podendo até prescindir totalmente deles;

- possibilitar maior rapidez de execução;

- economizar mão-de-obra no local;

- diminuir o peso (carga permanente) da estrutura.

E as principais desvantagens:

- em geral não possui um comportamento monolítico com o restante da estrutura, o que pode ser inconveniente sob o ponto de vista do contraventamento da edificação (exceção feita às vigotas com armadura em treliça);

- as vigotas de concreto armado e as vigotas protendidas são, às vezes, muito pesadas para manuseio, exigindo equipamentos para transporte e montagem no local.

No Brasil não há normas, recomendações ou especificações técnicas que regulamentem a execução de lajes com a utilização de elementos prémoldados na sua composição estrutural.

No presente momento está sendo confeccionada a Norma para a Laje Pré-Fabricada, em estudo no CB-02 - Comitê Brasileiro de Construção Civil (NBR/PROJETO 02:107.01-001, versão 30/06/97).

Nesta norma serão fixadas as condições exigíveis para o recebimento e utilização de componentes de lajes pré-fabricadas (vigas, elementos de enchimento e demais complementos adicionados na obra) a serem empregados nas edificações. Nesta norma estão sendo contempladas as lajes com vigotas de concreto armado e de concreto protendido de seção $T$ invertido e as vigotas com armação em forma de treliça. Estão previstos mais 3 textos: armaduras treliçadas, lajes alveolares e pré-lajes. 
A norma espanhola EF- $96^{3}$ é uma norma recente que trata das lajes pré-moldadas unidirecionais, sendo abordadas as características de cálculo e disposições construtivas.

\subsection{LAJES FORMADAS POR VIGOTAS PRÉ-MOLDADAS TRELIÇADAS}

As lajes treliçadas podem ser tratadas como estruturas monolíticas, devido à grande solidarização da armadura com o concreto moldado no local. A princípio, estas lajes têm o mesmo funcionamento estrutural de uma laje projetada da forma convencional, sendo que os elementos pré-moldados têm, no caso, função de racionalização na execução, proporcionando à obra rapidez e economia.

A armadura treliçada é uma estrutura formada por sistema de eletrofusão, de modo a formar duas treliças unidas pelo vértice. As diagonais proporcionam rigidez ao conjunto e excelentes condições de transporte e manuseio.

Em geral os comprimentos são padronizados de 8,10 e $12 \mathrm{~m}$ e com altura variando de 80 a $250 \mathrm{~mm}$. A armação treliçada (TR) pode ser classificada mediante um código, correspondendo a bitola da armadura do banzo superior (BS), das diagonais (D) e do banzo inferior (BI).

Tabela 2.1 Tipos usuais de treliças

\begin{tabular}{|c|c|c|c|c|}
\hline Código & Altura & \multicolumn{3}{|c|}{ diâmetro $(\mathrm{mm})$} \\
\cline { 3 - 5 } TR(H)(BS)(D)(BI) & $\mathrm{H}(\mathrm{cm})$ & $\mathrm{BS}$ & $\mathrm{D}$ & $\mathrm{BI}$ \\
\hline TR 08634 & 8 & 6 & 3,4 & 4,2 \\
\hline TR 12645 & 12 & 6 & 4,2 & 5 \\
\hline TR 16746 & 16 & 7 & 4,2 & 6 \\
\hline TR 20756 & 20 & 7 & 5 & 6 \\
\hline TR 25856 & 25 & 8 & 5 & 6 \\
\hline
\end{tabular}

\footnotetext{
${ }^{3}$ EF-96 Indicado na bibliografia: ESPANHA. Ministério de Fomento (1997).
} 
As armaduras podem ser classificadas mediante outros códigos, sendo característico de cada empresa que as fabricam.

Sob encomenda, as vigotas treliçadas (figura 2.4) podem ser fabricadas com diferentes quantidades de aço, sendo denominados de armadura adicional que é introduzida na base de concreto pré-moldado da vigota treliçada, com valores especificados pelo projetista. A armadura adicional pode ser composta do mesmo tipo de aço utilizado na treliça, fios de aço CA-60, ou ainda de barras de aço CA-50. Geralmente, até a bitola de 6,0 mm usam-se o CA-60 e a partir daí o CA-50.

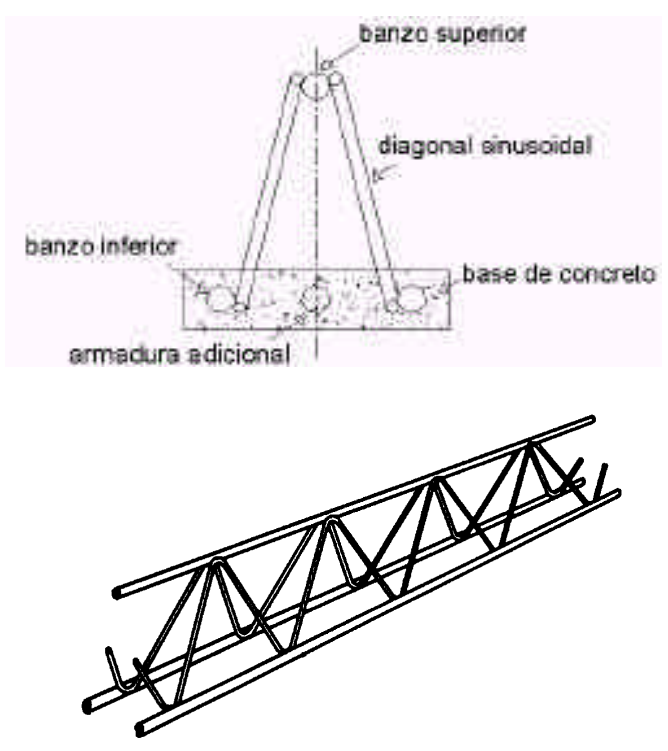

Fig.2.4 Seção da vigota com armadura em forma de treliça e perspectiva da armadura treliçada

A solidarização entre o concreto moldado no local ou chamado de concreto de capeamento e a vigota é favorecida pelas diagonais da treliça.

As principais vantagens do uso deste sistema com relação às demais lajes pré-fabricadas são:

- É de fácil manuseio no transporte horizontal e vertical, pois possui baixo peso próprio ( $\cong 0,1 \mathrm{kN} / \mathrm{m}$ ); 
- Redução dos escoramentos, proporcionando redução de mão-de-obra e materiais;

- Reduz a possibilidade do aparecimento de fissuras pela condição que oferece de grande aderência entre as vigotas e o concreto do capeamento;

- Facilita a colocação de nervuras moldadas no local na direção perpendicular às vigotas;

- Oferece uma maior resistência ao cisalhamento devido à presença das diagonais que exercem a função de estribos.

Além das lajes nervuradas, comumente chamadas de lajes treliçadas, podem-se obter outros arranjos estruturais, denominados de painéis treliçados, como pode ser visto na figura $\mathbf{2 . 5}$.

Como variáveis de projeto tem-se a sobrecarga, o valor do intereixo, que é função da dimensão do elemento de enchimento e da base de concreto da vigota, o tipo do elemento de enchimento, a altura da treliça e a condição estática da laje. Pode-se arbitrar a altura total da laje a ser usada fixados o vão e o valor da sobrecarga, sendo valores obtidos nos manuais de dimensionamento produzidos pelos próprios fabricantes dessas lajes.

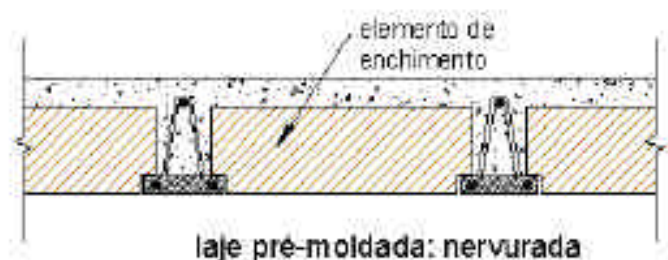

laje pre-moidada: nervurada

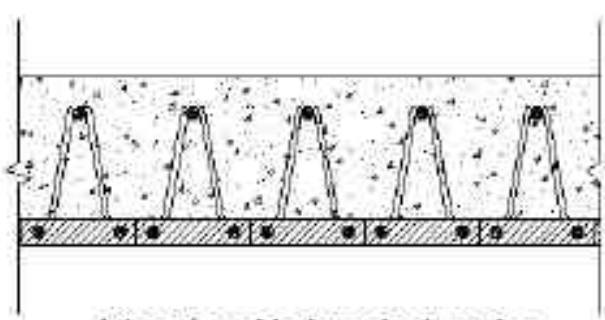

laje pré-moldada: painel maciço

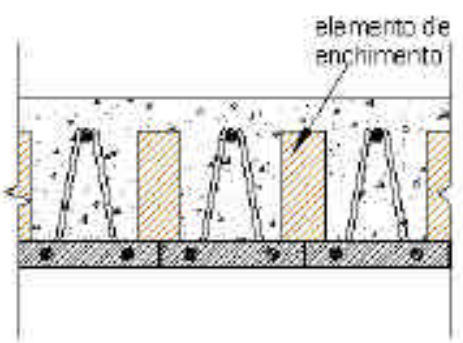

laje pre-moldada: painel c/ enchimento

Fig.2.5 Laje pré-moldada nervurada, painel maciço e painel c/ enchimento 
Os parâmetros principais que definem a laje são os seguintes:

a) Vão a ser vencido;

b) Sobrecarga (carga/área);

c) Cargas lineares ou pontuais (ex: paredes de alvenaria);

d) Altura total da laje $(h)$;

e) Espessura da capa de concreto $\left(h_{f}\right)$;

f) Resistência característica de compressão do concreto $\left(f_{c k}\right)$;

g) Intereixo de nervuras (intereixo);

h) Espessura das nervuras $\left(b_{w}\right)$;

i) Tipo de material de enchimento;

j) Altura e armadura da treliça $\left(h_{T}\right)$;
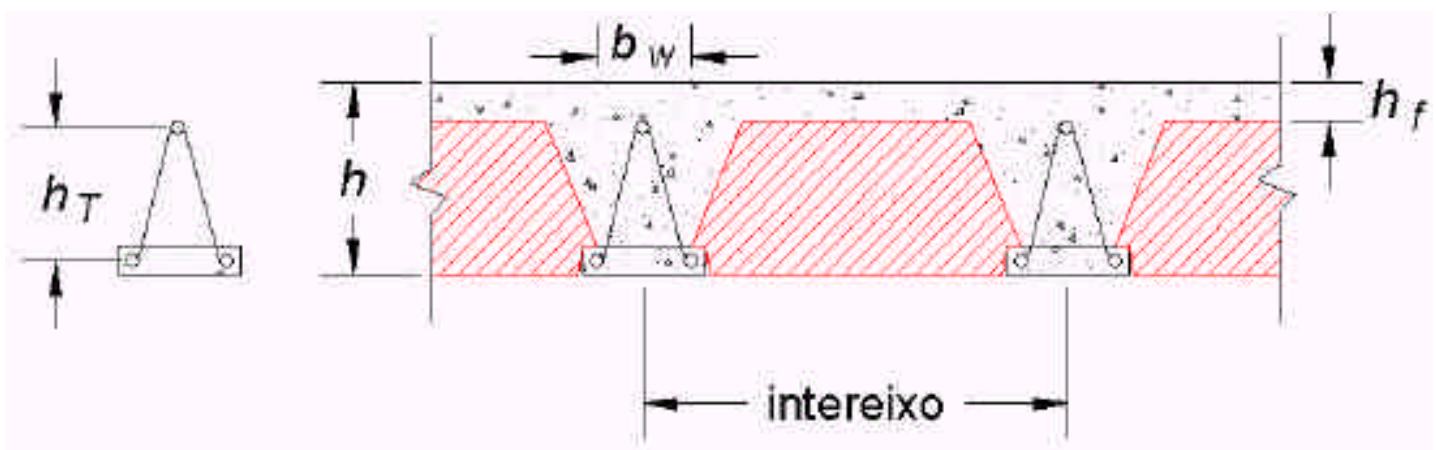

Fig.2.6 Dimensões principais - seção da laje treliçada

\subsection{ANÁLISE ESTRUTURAL E DIMENSIONAMENTO}

As lajes treliçadas podem ser classificadas como lajes unidirecionais ou bidirecionais. A laje pré-moldada unidirecional possui as nervuras (vigota e concreto moldado no local) dispostas em uma única direção. Mesmo em situações em que se adotam nervuras de travamento, estas são classificadas como lajes unidirecionais.

A laje pré-moldada bidirecional possui nervuras resistentes em duas direções ortogonais entre si. É formada por nervuras principais em uma 
direção (vigota e concreto moldado no local), e por nervuras transversais na outra direção. Ressalta-se que as lajes pré-moldadas bidirecionais ficam melhor executadas com o uso da vigota treliçada, pois estas permitem a passagem ou colocação de armadura na direção transversal.

A laje pré-moldada, como já comentado, é considerada como uma laje nervurada. A laje nervurada pode ser vista como uma alternativa da laje maciça, com a qual procura-se eliminar o concreto abaixo da linha neutra, criando-se vazios e podendo, assim, aumentar a altura da laje sem o aumento do consumo de concreto. Estas lajes têm sua resistência à tração concentrada apenas nas nervuras, entre as quais, eventualmente, podem ser colocados materiais não estruturais, de modo a tornar plana a superfície inferior da peça.

As lajes nervuradas, de um modo geral, são usadas para vencer grandes vãos, sendo usual que em edifícios de andares múltiplos elas sejam empregadas com vãos variando de 6 a 12 m, podendo inclusive atingir vãos maiores.

Forma-se, assim, um sistema estrutural altamente eficiente, constituído por um conjunto de nervuras dispostas em uma ou duas direções, com espaçamentos regulares entre si.

A NBR-6118 (1982) impõe algumas restrições para o cálculo das lajes nervuradas:

- os esforços solicitantes deverão ser calculados em regime elástico;

- a distância livre entre nervuras não deve superar $100 \mathrm{~cm}$;

- a resistência das nervuras ao cisalhamento deve ser verificada considerando-as como se fossem vigas isoladas, sempre que a distância entre elas ultrapassar $50 \mathrm{~cm}$;

- as nervuras deverão ser verificadas ao cisalhamento, como vigas, se a distância livre entre elas for superior a $50 \mathrm{~cm}$ e como laje em caso contrário;

- a espessura das nervuras não deve ser inferior a $4 \mathrm{~cm}$;

- a espessura da mesa de compressão não deve ser inferior a $4 \mathrm{~cm}$ ou a $1 / 5$ da distância livre entre as nervuras; 
- nas nervuras com espessura inferior a $8 \mathrm{~cm}$ não é permitido o emprego de armaduras de compressão no lado oposto à mesa;

- a resistência da mesa à flexão deverá ser verificada sempre que a distância livre entre as nervuras superar $50 \mathrm{~cm}$, ou quando o painel de laje tiver carga concentrada entre nervuras;

- o apoio das lajes deve ser feito ao longo de uma nervura;

- as lajes armadas em uma só direção devem ser providas de nervuras transversais de travamento sempre que haja cargas concentradas a distribuir, ou quando o vão teórico for superior a $4 \mathrm{~m}$, exigindo-se duas nervuras, no mínimo, se esse vão ultrapassar $6 \mathrm{~m}$;

Os esforços solicitantes nas lajes nervuradas bidirecionais podem ser calculados do mesmo modo que para as lajes maciças, desde que se observem as restrições impostas pela NBR-6118 (1982), vistas na página anterior. Para as lajes unidirecionais, considera-se como faixas de vigas isoladas, respeitando-se também as restrições impostas pela norma.

As lajes nervuradas de grandes dimensões em planta e as que são submetidas a significativas cargas concentradas ou distribuídas em linha devem ter seus esforços solicitantes determinados por processos que considerem de modo adequado as posições das cargas aplicadas, a localização e a rigidez das diferentes nervuras, bem como as verdadeiras condições de apoio das lajes, levando-se em conta as posições dos pilares e a deformabilidade das vigas de sustentação.

Através de análises estruturais em lajes com carregamento perpendicular ao seu plano, obtêm-se os esforços solicitantes: momento fletor, força cortante e, dependendo do processo utilizado, obtêm-se, também, o momento de torção. $O$ desconhecimento da capacidade das lajes nervuradas para absorver momentos de torção e também a não necessidade da sua consideração para o equilíbrio, faz com que se desprezem ou adotem valores muito pequenos da rigidez associada a esse esforço. 
Para a definição da seção transversal da nervura, de modo a obter os valores de rigidez à torção e à flexão, segue que:

Segundo a NBR-6118 (1982), item 3.2.2.2, para o dimensionamento ou cálculo da deformação, a parte da laje a considerar como elemento da viga $\left(b_{f}\right)$ será:

$$
b_{f}=b_{w}+2 \cdot b_{1} \quad \text { sendo, } \quad b_{1} \leq\left\{\begin{array}{l}
0,10 \cdot a \\
8 \cdot h_{f} \\
0,5 \cdot b_{2}
\end{array}\right.
$$

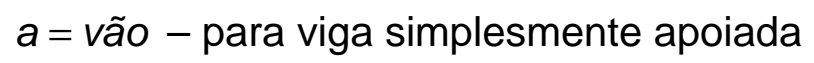

$a=3 / 4 . v a ̃ o-$ tramo c/ momento em uma só extremidade

$a=3 / 5 \cdot v a ̃ o-$ tramo $\mathrm{c} /$ momentos nas duas extremidades

$a=2 . v a ̃ o-p a r a ~ v i g a ~ e m ~ b a l a n c ̧ o$

Fazendo-se a analogia de que a capa de concreto moldado no local seja a laje e as nervuras sejam um conjunto de viga tem-se:

As abas colaborantes de comprimento $b_{1}$ (figura 2.7), não podem superar em 8 vezes a espessura da mesa, sendo, portanto $b_{f}=b_{w}+16 . h_{f}$. Utilizando-se os valores mínimos $b_{w}=4 \mathrm{~cm}$ e $h_{f}=4 \mathrm{~cm}$, resulta $b_{f}=68 \mathrm{~cm}$.

Deste modo, adotando-se um intereixo usual igual a $50 \mathrm{~cm}$, por exemplo, a largura da mesa de compressão $\left(b_{f}\right)$ a ser considerada para o dimensionamento será o próprio valor do intereixo.

As outras restrições: $b_{1} \leq\left\{\begin{array}{l}0,10 . a \\ 0,5 . b_{2}\end{array}\right.$, que dependem do valor da distância entre as faces das nervuras e do vão, em geral, serão satisfeitas com a escolha do intereixo igual a $50 \mathrm{~cm}$. 


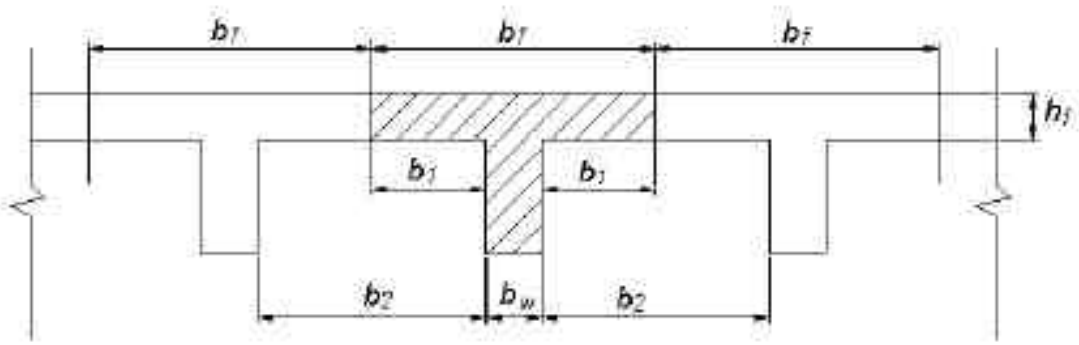

Fig.2.7 Largura da mesa de compressão

Segundo a NBR-6118 (1982), para o dimensionamento da estrutura ao Estado Limite Último, considera-se a majoração das ações igual a 1,4 e os coeficientes de minoração da resistência do concreto e do aço iguais a 1,4 e 1,15, respectivamente, considerando-se a atuação de todas as cargas permanentes e acidentais.

De acordo com a NBR-7197 (1989), para a verificação dos Estados Limites de Utilização, no que diz respeito a verificação de Estados Limites de deformações excessivas podem ser utilizadas as combinações freqüentes das ações:

$$
F_{d}=F_{g}+\Psi_{1} \cdot F_{q 1} \quad \text { sendo, }
$$

$\Psi_{1}$ - fator de utilização;

$F_{d}$ - Ações atuantes para a verificação do estado limite de deformações excessivas;

$F_{g}$ - Ações de caráter permanente (peso próprio da laje, alvenarias e revestimentos);

$F_{q 1}$ - Ações principais de caráter acidental (cargas variáveis, sobrecargas).

Fator de utilização, $\Psi_{1}$, a ser considerado:

$\Psi_{1}=0,3$ - Edifícios onde não haja predominância de pesos e 
equipamentos que permaneçam fixos por longos períodos de tempo, nem de elevadas concentrações de pessoas;

$\Psi_{1}=0,6$-Edifícios onde haja predominância de pesos de equipamentos que permaneçam fixos por longos períodos de tempo, e de elevadas concentrações de pessoas;

$\Psi_{1}=0,7$ - Bibliotecas, arquivos, oficinas e garagens.

As limitações dos deslocamentos máximos, denominados de flechas, medidos a partir do plano que passa pelos apoios são:

- $1 / 300$ do vão teórico, ou $1 / 150$ do comprimento do balanço, quando atuarem todas as cargas atuantes para a verificação do estado limite;

- $1 / 500$ do vão teórico, ou $1 / 250$ do comprimento do balanço, quando atuarem somente as cargas acidentais.

A verificação e/ou dimensionamento ao cisalhamento é realizada segundo o anexo da NBR-7197 (1989), que modifica a NBR-6118 (1982).

Em situações que haja necessidade de estribos, pode-se verificar a armadura já existente, (diagonais da armação treliçada) e geralmente esta já é suficiente para o combate ao cisalhamento. Porém, é indispensável que ela faça a ligação do banzo tracionado com o banzo comprimido da nervura, o que exige que a barra de aço do banzo superior da treliça fique alojada dentro da mesa de compressão.

O arranjo das armaduras das lajes é essencialmente definido em função dos esforços de flexão. Para o dimensionamento das lajes nervuradas submetidas ao momento fletor último ou de cálculo, utiliza-se a 
teoria de flexão normal simples de peças de concreto armado, com seção retangular ou seção "T", ou fazendo-se uma analogia com a laje maciça.

A partir daí, chega-se ao valor da armadura de tração que trabalhará na base de concreto (aço do banzo inferior da treliça e adicionais). Se a armadura necessária for maior que a armadura do banzo inferior da treliça, introduzem-se armaduras adicionais, podendo estas serem fios de aço CA60 ou barras de aço CA-50.

Havendo nervuras transversais, a disposição das armaduras nesta direção pode ser feita facilmente pelo emprego de barras isoladas que cruzam as treliças das nervuras principais, chamadas de nervuras longitudinais.

Informações complementares para o dimensionamento das lajes treliçadas:

\section{a) Armadura de distribuição}

Na capa de concreto da laje pré-moldada, é colocada uma armadura denominada armadura de distribuição.

A armadura de distribuição permite um melhor travamento da estrutura da laje. Combate também o cisalhamento entre abas e alma das vigotas. Esta armadura tem por objetivo promover um comportamento conjunto mais efetivo da laje com a estrutura; reduzir os efeitos da retração diferencial entre o concreto moldado no local e o concreto pré-moldado; reduzir a abertura de fissuras devida à retração e aos efeitos térmicos; propiciar melhor distribuição transversal de cargas localizadas e propiciar um comportamento mais efetivo de diafragma, na transferência de ações horizontais. 


\section{b) Fase transitória}

Durante a fase de montagem a estrutura fica submetida aos esforços de flexão provenientes do peso próprio das vigotas treliçadas, dos elementos de enchimento, do peso dos equipamentos, dos operários e finalmente do concreto de capeamento. Nesta fase há necessidade de cimbramento para suportar os esforços da fase de montagem e concretagem, cujas distâncias são variáveis em cada caso e deverão ser especificadas na planta de execução.

A situação mais desfavorável é a fase de colocação da capa de concreto no local. Para a situação em que a nervura está sobre dois apoios extremos e um apoio interno do cimbramento, os momentos fletores são bem distintos dos correspondentes na situação definitiva. Deve-se fazer um estudo prévio dos efeitos destes esforços, como por exemplo, a possibilidade de ocorrer a flambagem no banzo superior da treliça devido a um não dimensionamento correto do espaçamento do cimbramento.

\section{c) Nervura submetida ao momento fletor negativo:}

Em casos onde se tenham lajes unidirecionais contínuas, pode ser utilizado o modelo de viga contínua desde que se faça o dimensionamento da nervura ao momento fletor negativo. Para as lajes bidirecionais, do mesmo modo que para as laje unidirecionais, considera-se a continuidade entre as lajes, sendo recomendado que os esforços sejam determinados mediante métodos numéricos confiáveis, como por exemplo, através de modelos de grelha.

Em muitos casos, não é considerada a continuidade mediante a aplicação de modelos de cálculo, e sim, arbitrando-se momentos fletores sobre os apoios intermediários em função de um certo valor de armadura "negativa" considerada na nervura submetida ao momento fletor negativo. 
Deste modo, calculam-se as nervuras como se fossem bi-apoiadas, com momentos aplicados nas extremidades dos vãos com valores iguais aos momentos arbitrados.

Quando a nervura for submetida a um momento fletor negativo, com tração na sua face superior, o dimensionamento deve ser feito como se fosse uma seção retangular de largura igual à largura da alma $\left(b_{w}\right)$, desprezando-se totalmente a mesa, como pode ser visto na figura 2.8. Com isso torna-se necessária uma maior quantidade de armadura para absorver um mesmo momento, se comparado à seção submetida ao momento fletor positivo.

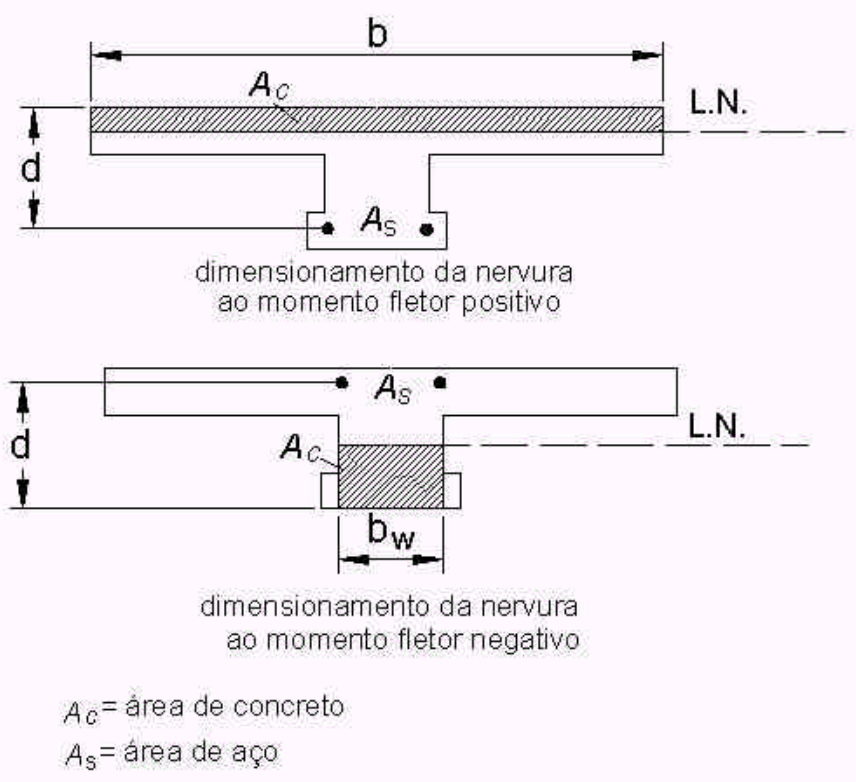

Fig.2.8 Dimensionamento da nervura - mesa comprimida e tracionada

Mesmo em painéis isolados de laje, sabe-se que há um semiengastamento dos elementos da laje nas vigas de extremidade ou cinta de amarração. Este semi-engastamento é função direta da rigidez à torção das vigas.

Mesmo que a laje tenha sido calculada como simplesmente apoiada, é recomendado, portanto, a adoção de uma armadura construtiva sobre o apoio de extremidade da laje, a fim de se reduzir ou até mesmo eliminar a fissuração da laje, próxima aos apoios. 


\section{MÉTODOS E TÉCNICAS}

\subsection{CONSIDERAÇÕES INICIAIS}

Apresentam-se neste capítulo os métodos e técnicas utilizados para as análises das lajes nervuradas formadas por vigotas pré-moldadas.

A analogia de grelha, a consideração da não-linearidade e os recursos computacionais disponíveis constituem nos métodos e técnicas utilizados para a realização das análises nas lajes pré-moldadas treliçadas. 


\subsection{ANALOGIA DE GRELHA}

\subsubsection{FUNDAMENTOS GERAIS}

A analogia da grelha consiste em representar uma laje ou mesmo um pavimento de um edifício através de uma grelha equivalente. A rigidez longitudinal da laje é concentrada nas barras longitudinais e a rigidez transversal é concentrada nas barras transversais (figura 3.1).

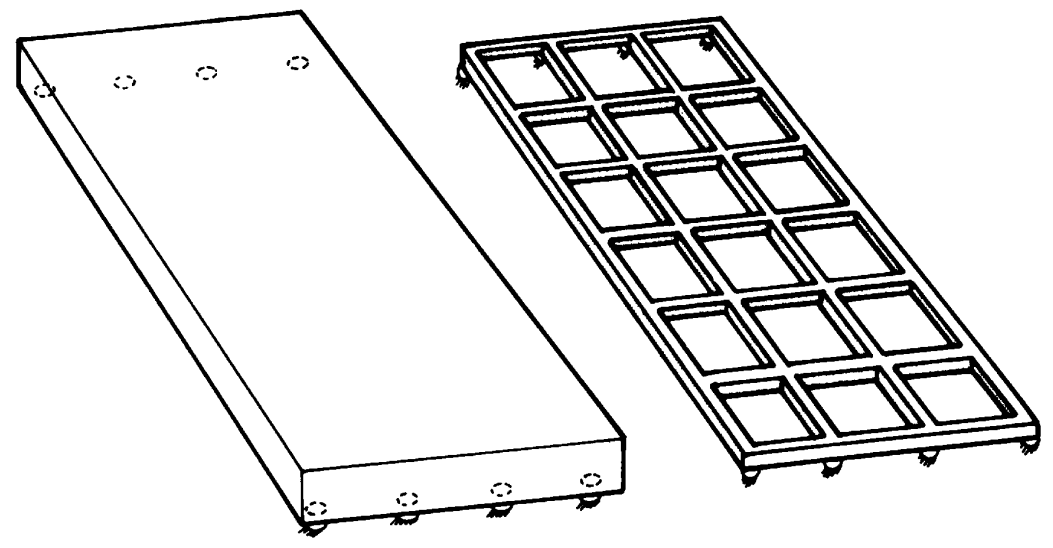

Fig.3.1 Laje e grelha equivalente. Fonte HAMBLY (1991)

Esta técnica, de fácil compressão, permite o uso de elementos lineares. A resolução da estrutura resulta num problema simples de análise matricial aplicada a uma grelha. Acrescenta-se que a analogia de grelha pode ser o modelo mais indicado para resolver algumas estruturas de lajes, como por exemplo, a lajes nervuradas, quando comparada com à teoria das lajes isótropas.

O uso da analogia de grelha permite considerar a rigidez das lajes vizinhas; as vigas podem ser consideradas como elementos deformáveis e também é possível fazer um modelo mais adequado na interação das lajes com as vigas. Outra vantagem é poder considerar facilmente nas lajes, cargas que não tenham distribuição uniforme, como por exemplo, cargas lineares e/ou pontuais.

$\mathrm{Na}$ discretização das lajes nervuradas pré-moldadas, em grelha, determina-se a malha de acordo com a localização das nervuras. Se ocorre 
uma laje armada em uma direção, a localização das barras nesta direção está definida, podendo-se variar o número de barras na direção perpendicular às nervuras. Agora se ocorre uma laje nervurada armada nas duas direções, a malha da grelha já estará definida para as duas direções.

O carregamento pode ser montado aplicando-se a força concentrada diretamente nos nós da grelha, em função das áreas de influência $\left(A_{i}\right)$ de cada respectivo nó (fig. 3.2).

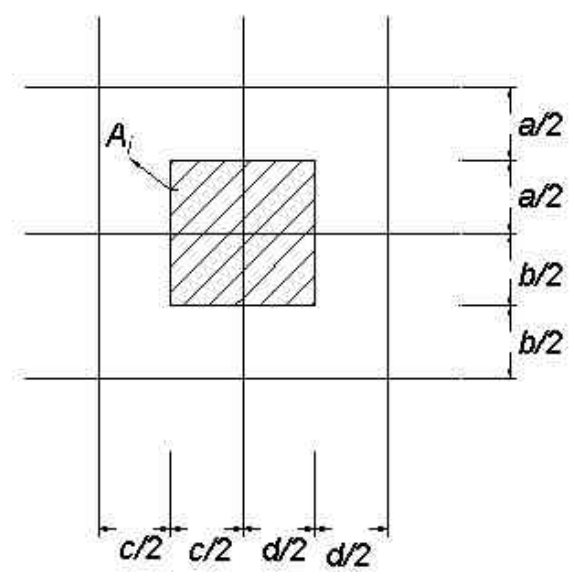

Fig.3.2 Área de influência para determinação do carregamento em um nó genérico (i)

\subsubsection{PARÂMETROS RELATIVOS À RIGIDEZ À TORÇÃO}

Em modelo de grelha, além dos esforços solicitantes de momento fletor e força cortante, surgem os esforços solicitantes de momento de torção, sendo este valor, função da rigidez ou capacidade à torção dos elementos. A rigidez à torção, do mesmo modo que a rigidez à flexão, constitui parâmetro de estudo em modelos de grelha.

Em uma estrutura, as tensões provocam, além de deformações na sua direção, deformações na direção transversal. O coeficiente de poisson (v) é a razão entre as deformações transversal e longitudinal e é variável 
com a resistência à compressão do concreto e com o nível de solicitação, adotando-se para os cálculos práticos o valor médio 0,2 conforme LEONHARDT (1981). A NBR-6118 (1982) sugere também este valor.

De posse do módulo de deformação longitudinal do concreto $\left(E_{c}\right)$, do coeficiente de Poisson e supondo-se o concreto não fissurado, o módulo de deformação transversal $(G)$ do concreto pode ser determinado, de acordo com a teoria da elasticidade pela expressão:

$$
G=\frac{E_{c}}{2(1+v)}
$$

Segundo LEONHARDT (1981), numa peça de concreto armado, mesmo no Estádio I, já se observa uma queda na rigidez à torção. Atribui-se esse efeito à presença de microfissuras existentes na peça. $O$ módulo de elasticidade transversal $G$ só pode ser utilizado no estádio I, para efeito de cisalhamento e de torção. No estádio II o módulo de elasticidade $E$ é o determinante, porque as deformações por cisalhamento e torção são calculadas através de modelos de treliça, nas quais as barras das treliças se deformam de acordo com suas rigidezes à deformação longitudinal.

Para que seja levado em conta o efeito da queda de rigidez à torção, devido à fissuração, TAKEYA et alii (1985) recomendam que seja adotado $G=0,15 E_{c}$.

O cálculo ou estimativa do momento de inércia à torção $\left(I_{T}\right)$ para seções transversais homogêneas retangulares (figura 3.3) é vista em LEONHARDT (1979), sendo dado pela expressão:

$$
I_{T}=\alpha \cdot b^{3} \cdot d \quad \text { sendo } \alpha \text { determinado por: }
$$

\begin{tabular}{|c|c|c|c|c|c|c|c|c|c|}
\hline $\mathrm{d} / \mathrm{b}$ & 1,0 & 1,5 & 2,0 & 3,0 & 4,0 & 6,0 & 8,0 & 10,0 & $\infty$ \\
\hline$\alpha$ & 0,141 & 0,196 & 0,229 & 0,263 & 0,281 & 0,299 & 0,307 & 0,313 & 0,333 \\
\hline
\end{tabular}




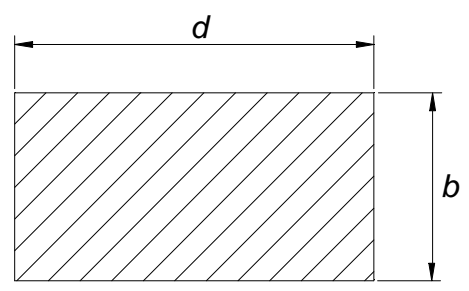

Fig.3.3 Seção transversal homogênea retangular

Para vigas com seção I ou $T$ (figura 3.4), de acordo com LEONHARDT (1979), divide-se a seção em retângulos, obtendo $I_{T}$ como a soma dos valores dos retângulos parciais. Admite-se, pois que cada retângulo parcial gira em torno do respectivo centro de cisalhamento. $\mathrm{Na}$ realidade, existe apenas um eixo de rotação global, que passa pelo centro de cisalhamento da seção total. No entanto o cálculo do $I_{T}$ por este método simplificado conduz a resultados satisfatórios.

$$
I_{T}=\sum I_{T i}=I_{T_{l}}+I_{T_{2}}+I_{T_{3}}+\ldots
$$
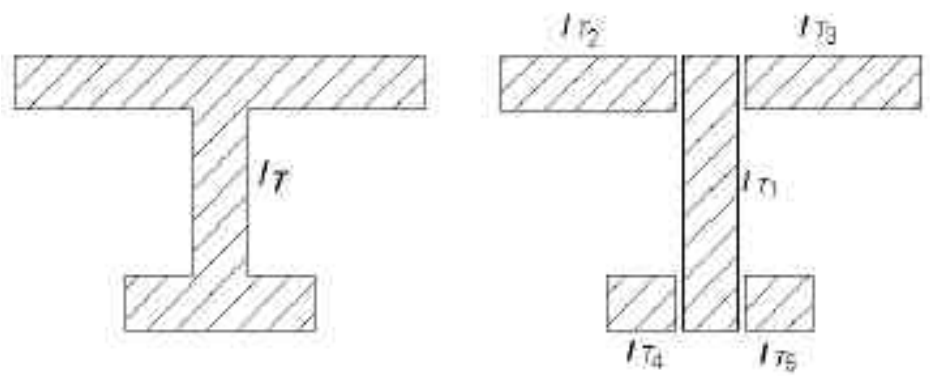

Fig.3.4 Seção I - Cálculo do momento de inércia à torção, segundo LEONHARDT (1979)

Outro modo de estimar o momento de inércia à torção das vigas I (figura 3.5) é, de acordo com a expressão sugerida por BARES, (1966):

$$
I_{T}=\frac{1}{3}\left[\left(h-h_{f 1}-h_{f 2}\right) \cdot b_{w}^{3}+0,5 \cdot\left(b_{f 1} \cdot h_{f 1}^{3}+b_{f 2} \cdot h_{f 2}^{3}\right)\right]
$$




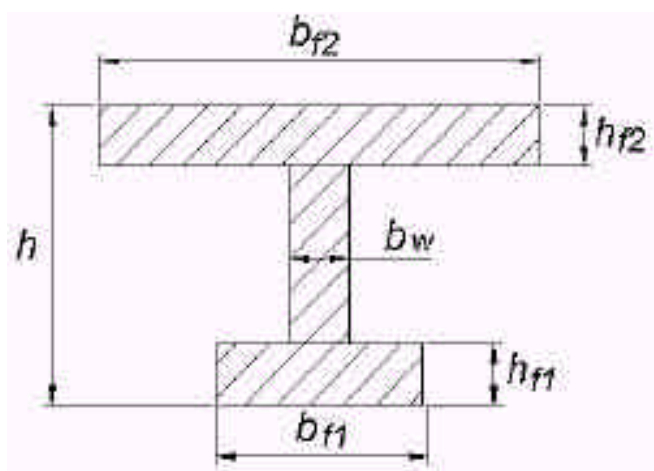

Fig.3.5 Seção I - Cálculo do momento de inércia à torção, segundo BARES (1966)

A rigidez à torção $\left(k_{T}\right)$, é função direta do módulo de deformação transversal $(G)$ e do momento de inércia à torção $\left(I_{T}\right)$, sendo:

$$
K_{T}=G \cdot I_{T}
$$

Segundo o COMITE EURO-INTERNATIONAL DU BETON (1991) pode-se estimar a rigidez à torção para o estádio I por:

$K_{\mathrm{I} T}=0,3 \cdot E_{C} \cdot I_{T}$ - coeficiente de rigidez à torção no estádio I

Agora, para o estádio II, o CEB-90 (1991) considera o valor:

$K_{\mathrm{II} T}=0,10 \cdot E_{C} \cdot I_{T}$ - coeficiente de rigidez à torção no estádio II

Para o caso de haver interação entre os esforços de flexão e torção, a formulação resulta em:

$K_{\text {II } T}=0,05 \cdot E_{C} \cdot I_{T}$ - coeficiente de rigidez à torção no estádio II

\footnotetext{
${ }^{4}$ COMITE EURO-INTERNATIONAL DU BETON (1991) - Indica-se a partir de agora como CEB-90 (1991).
} 


\subsubsection{DISCRETIZAÇÃO DA LAJE PRÉ-MOLDADA}

O painel ou pavimento constituído por laje nervurada pré-moldada é discretizado em uma grelha.

Em função do valor do intereixo (distância entre o centro de duas nervuras consecutivas), define-se a malha da grelha na direção paralela à nervura.

Para uma melhor apresentação, mostra-se a seguir, como exemplo, a discretização de um painel de laje unidirecional formado por vigotas prémoldadas e concreto moldado no local. As dimensões adotadas (figuras $\mathbf{3 . 6}$ e 3.7) são de acordo com manuais de dimensionamento produzidos por fabricantes deste tipo de laje. Neste exemplo utilizam-se os dados de LIMA (1983).

Seja o painel constituído de laje pré-moldada:

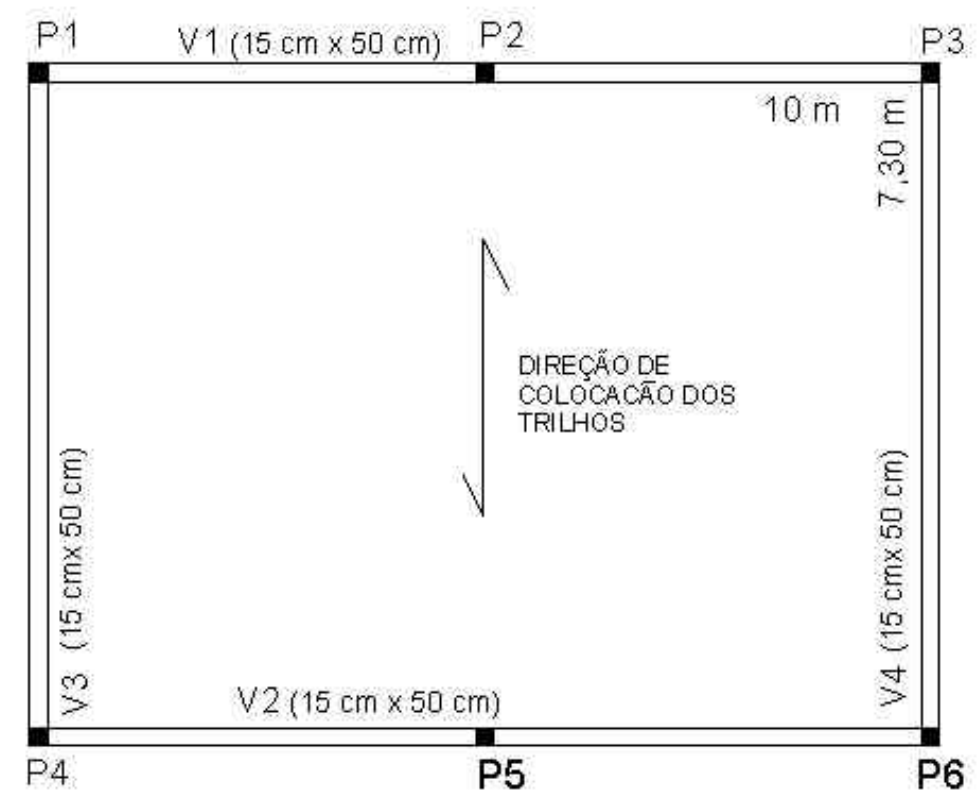

Fig.3.6 Esquema de um painel de laje apoiado em vigas 


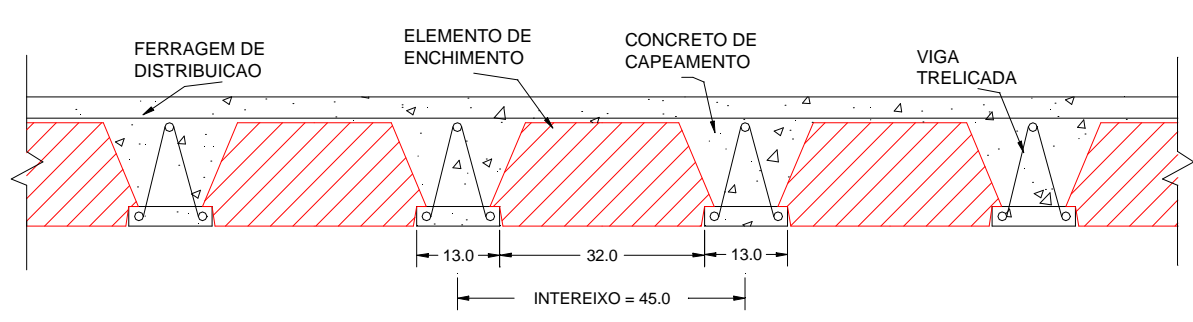

Fig.3.7 Seção da nervura que contém a vigota pré-moldada

Por se tratar de uma laje unidirecional, na direção transversal tem-se apenas a colaboração do concreto de capeamento. Para a discretização da grelha, considera-se, neste caso, o espaçamento entre as barras da grelha iguais tanto na direção longitudinal quanto na direção transversal às vigotas pré-moldadas, como pode ser visto nas figuras 3.8 e 3.9 .
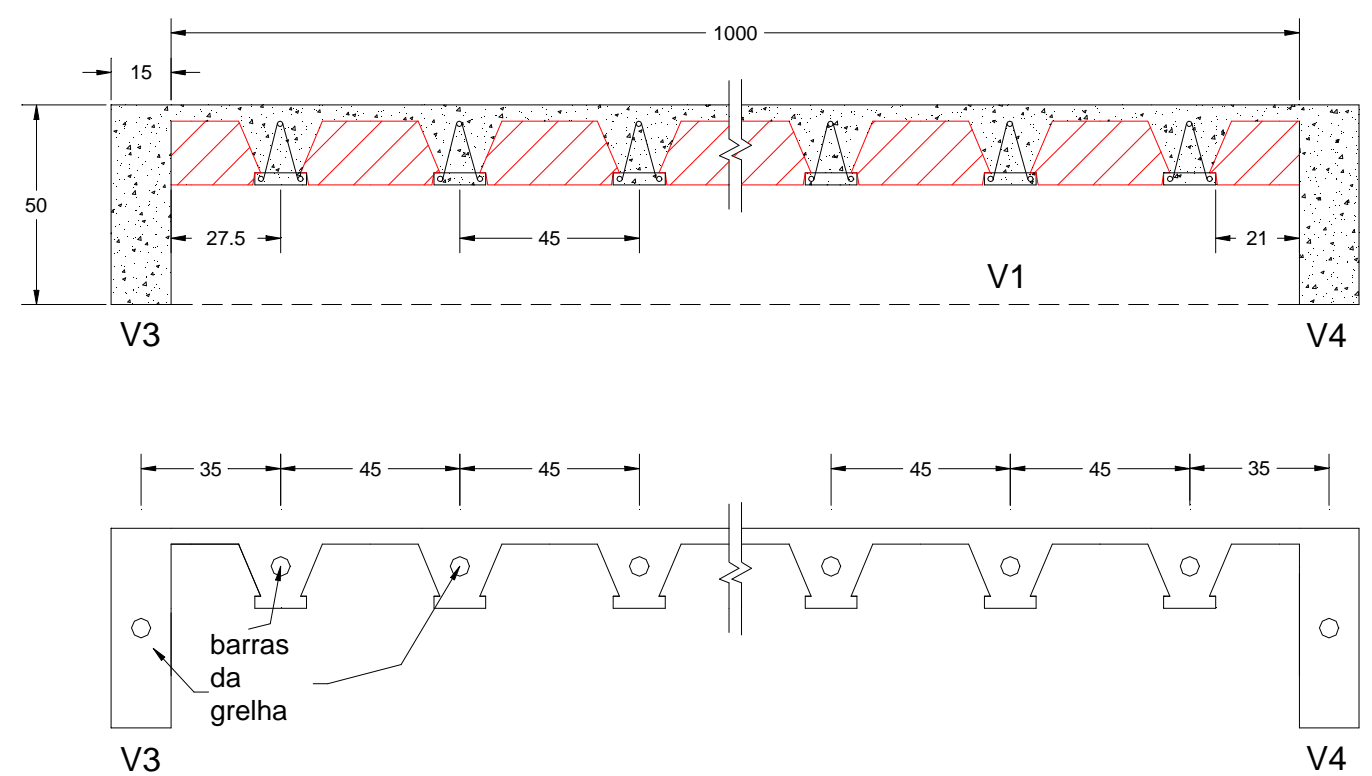

Fig.3.8 Localização das barras da grelha na direção longitudinal às vigotas (dimensões em $\mathrm{cm}$ ) 

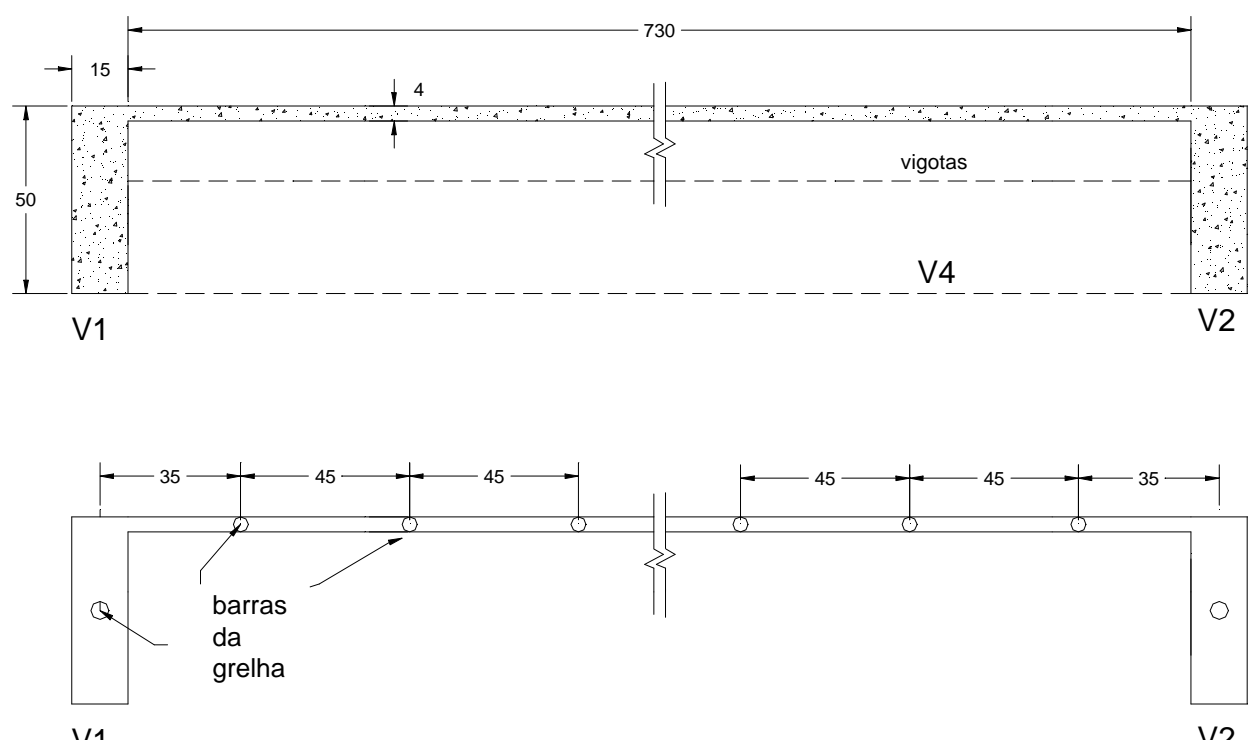

Fig.3.9 Localização das barras da grelha na direção transversal às vigotas (dimensões em $\mathrm{cm}$ )

O esquema da malha é indicado na figura 3.10. Nota-se, nesta grelha, que todos os pontos referentes às vigas de extremidade possuem apoios, restringindo-se o deslocamento vertical; esta hipótese pode ser adotada para apoio de laje sobre alvenaria portante, por exemplo.

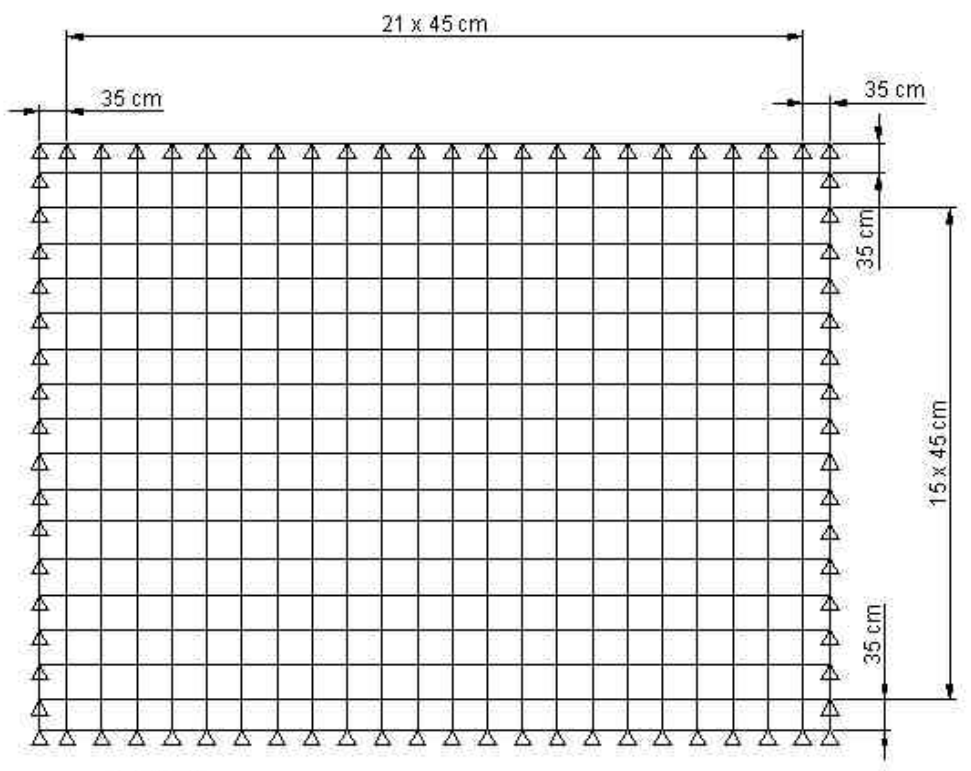

$\triangle$ apoio

Fig.3.10 Malha da grelha 


\subsection{CONSIDERAÇÃO DA NÃO-LINEARIDADE}

A avaliação dos deslocamentos e esforços solicitantes em uma estrutura torna-se mais confiável ou segura com uma devida estimativa dos parâmetros de rigidez do concreto armado. Isto se torna complexo pelo fato de que parte do elemento trabalha no Estádio I, parte no Estádio II e, dependendo do carregamento ou disposições geométricas, no Estádio III; além dos efeitos da retração e deformação lenta do concreto. Para isto temse desenvolvido modelos não-lineares.

Os modelos não-lineares podem ser formulados de várias maneiras. Quanto à discretização da seção transversal, existem modelos que a idealizam constituída por camadas superpostas. Quanto às teorias, podem ser citadas a teoria elastoplástica, a teoria do dano e a da fratura, dentre outras.

Neste trabalho apresenta-se um modelo não-linear, mediante a relação momento-curvatura do CEB-90 (1991), sendo função da fissuração do concreto e também das equações constitutivas dos materiais, aço e concreto. Apresenta-se também a formulação empírica proposta por BRANSON (1963).

\section{a) Relação momento x curvatura do CEB-90 (1991)}

Uma maneira possível de relacionar o momento atuante $(M)$ com a curvatura $(1 / r)$ é a partir do modelo que considera a flexão simples pura atuando em um trecho de peça em que a seção está contida. A partir do diagrama momento-curvatura define-se a rigidez média à flexão da seção.

$$
\begin{array}{ll}
\frac{M}{E_{c} I}=\frac{1}{r} \quad \text { sendo }, & E_{c} \text { - módulo de elasticidade do concreto } \\
\text { I - momento de inércia da seção considerada }
\end{array}
$$


De acordo com o CEB-90, o módulo de elasticidade $\left(E_{c}\right)$ pode sofrer uma redução $\left(E_{c s}\right)$ para levar-se em conta 0 início de plastificação do concreto, sendo:

$$
\begin{aligned}
& E_{c}=21500\left(\left(f_{c k}+8\right) / 10\right)^{\frac{1}{3}}(\mathrm{MPa}) \quad ; \quad E_{c s}=0,85 E_{c} \quad(\mathrm{MPa}) \\
& f_{c k} \text { - é o valor da resistência característica do concreto com } 28 \text { dias }
\end{aligned}
$$

Na figura 3.11 é representada a relação momento-curvatura de uma seção de concreto armado submetida à flexão simples. O CEB-90 considera que a curvatura média é influenciada pela fissuração antes da atuação do valor do momento de início de fissuração $\left(M_{r}\right)$, isto é, para o valor de $M_{r} \sqrt{\beta_{b}}$. Para um momento superior a este limite há uma sensível diminuição da rigidez à flexão, embora não exista, em princípio, sinal de escoamento do aço ou plastificação do concreto comprimido. Este trecho corresponde ao estádio II. Conforme o CEB-90 o valor do momento de fissuração $M_{r}$ pode ser determinado por:

$$
M_{r}=W_{1} f_{c t} \quad f_{c t m}=1,4\left(\frac{f_{c k}}{10}\right)^{\frac{2}{3}} \quad(\mathrm{MPa})
$$

$f_{c t m}$ - resistência média à tração axial do concreto;

$f_{c t}$ - resistência média à tração por flexão do concreto, sendo:

$W_{1}$ - módulo de resistência do estádio I, incluindo a armadura.

A NBR-7197 (1989) no seu anexo dispõe que a resistência à tração na flexão, quando da verificação do estado limite de formação de fissuras, deve ser considerada igual a 1,2 vezes o valor de sua resistência à tração axial, para vigas de seção T e 1,5 vezes o valor da resistência à tração axial para vigas com seção retangular. Portanto, na ausência de valores de 
resistência à tração na flexão, obtidos através de ensaios, consideram-se os valores iguais a:

$$
\begin{aligned}
& f_{c t}=1,2 . f_{c t m} \text { para vigas com seção "T"; } \\
& f_{c t}=1,5 . f_{c t m} \text { para vigas retangulares; }
\end{aligned}
$$

Um terceiro trecho da curva ocorre quando o aço tracionado escoa ou o concreto comprimido entra em estágio de plastificação; há uma variação sensível de rigidez no trecho. Nesta situação as deformações começam a ser grandes, pelo menos na região próxima a esta seção. Este trecho é limitado entre o valor do momento de escoamento $\left(M_{y}\right)$ e momento último ou de ruína $\left(M_{u}\right)$.

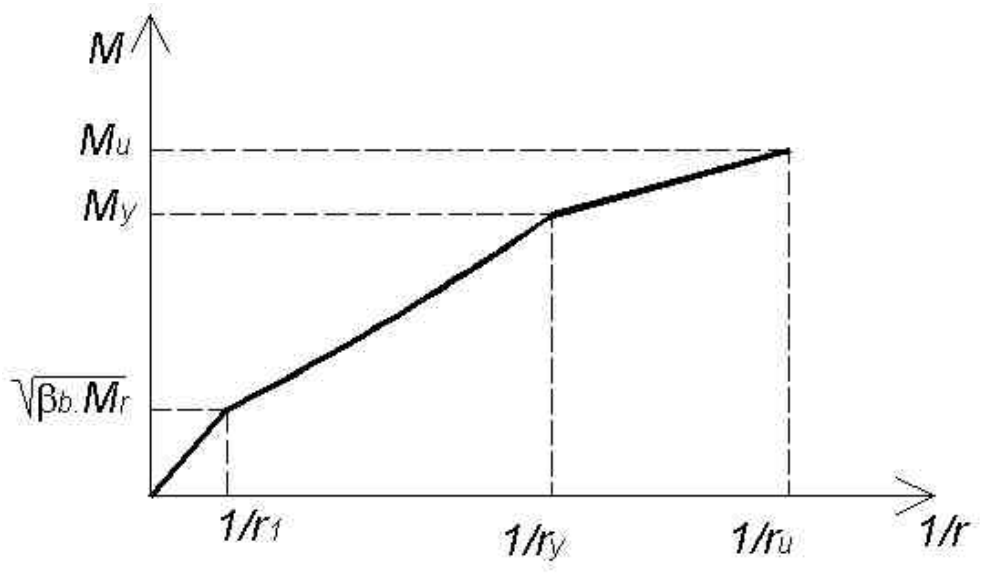

Fig.3.11 Momento fletor x curvatura segundo o CEB-90 (1991)

Estádio I - $M<M_{r} \sqrt{\beta_{b}}$ :

$\frac{1}{r}=\frac{1}{r_{1}}=\frac{M_{r} \sqrt{\beta_{b}}}{E_{c} I_{\mathrm{I}}} \quad$ sendo, $\quad \beta_{b}>\beta_{1} \beta_{2}$

Estádio II $-M_{r} \sqrt{\beta_{b}}<M<M_{y}$ :

$\frac{1}{r}=\frac{1}{r_{2}}-\frac{1}{r_{t s}} \quad$ sendo: $\quad \frac{1}{r_{t s}}=\left(\frac{1}{r_{2 r}}-\frac{1}{r_{1 r}}\right) \cdot \beta_{b} \cdot\left(\frac{M_{r}}{M}\right)$ 


$$
\begin{aligned}
& \frac{1}{r_{t s}} \quad \text { - rigidez do concreto à tração "tension stiffening" } \\
& \frac{1}{r_{2}}=\frac{M}{E_{c s} I_{\mathrm{II}}} \quad ; \quad \frac{1}{r_{2 r}}=\frac{M_{r}}{E_{c s} I_{\mathrm{II}}} \quad ; \quad \frac{1}{r_{1 r}}=\frac{M_{r}}{E_{c} I_{\mathrm{I}}}
\end{aligned}
$$

Para $M>M_{y}:$

$$
\frac{1}{r}=\frac{1}{r_{y}}-\left(\frac{1}{r_{2 r}}-\frac{1}{r_{1 r}}\right) \cdot \beta_{b} \cdot\left(\frac{M_{r}}{M_{y}}\right)+\frac{\left(M-M_{y}\right)}{2 K_{\mathrm{III}}} \quad \text { sendo, } \quad K_{\mathrm{III}}=\frac{M_{u}-M_{y}}{\frac{1}{r_{u}}-\frac{1}{r_{y}}}
$$

sendo:

$M$ - momento fletor atuante na seção ou trecho analisado;

$l_{\text {I }}$ - momento de inércia da seção no estádio I

$I_{\text {II }}$ - momento de inércia da seção no estádio II

$\beta_{b}$ - produto de coeficientes que levam em conta a aderência das barras de aço e a repetitividade dos carregamentos, sendo em função de:

$\beta_{1}=0,5$ para barras de má aderência e 1,0 caso contrário

$\beta_{2}=0,5$ para cargas repetitivas ou 0,8 para o primeiro carregamento

\section{b) Formulação de BRANSON (1963)}

A formulação de BRANSON foi desenvolvida para o cálculo ou estimativa de flechas em vigas. Caracteriza-se pela redução progressiva do momento de inércia médio ou equivalente $\left(\mathrm{I}_{e}\right)$ da seção entre os Estádios I e II puro, de acordo com o momento fletor atuante $(M)$, maior do que o momento relativo à fissuração da peça $\left(M_{r}\right)$.

Apresenta-se a função interpoladora proposta por BRANSON a seguir: 


$$
I_{e}=\left(\frac{M_{r}}{M}\right)^{3} I_{O}+\left[1-\left(\frac{M_{r}}{M}\right)\right]^{3} I_{\mathrm{I}} \leq I_{O} \quad \text { sendo: }
$$

$M_{r}$ Momento fletor de início de fissuração;

Io Momento de inércia da seção bruta não fissurada, podendo-se substituir pela seção homogeneizada tomando a relação do módulo de elasticidade do aço e do concreto;

$I_{I I} \quad$ Momento de inércia da seção fissurada ou momento de inércia do estádio II;

Salienta-se que a norma espanhola EF-96 (1997) recomenda esta formulação para o cálculo da flecha instantânea em lajes pré-moldadas unidirecionais. Deste modo, consideram-se as nervuras da laje como vigas isoladas.

$O$ valor da rigidez calculada mediante a relação momento $x$ curvatura segundo o CEB-90, refere-se a uma dada seção submetida ao momento fletor. Sendo portanto de fundamental importância a discretização ou divisão do modelo em vários elementos, com isso obtêm-se os valores de rigidez em várias localizações do modelo. O número de elementos a ser considerado irá depender do tipo de modelo em estudo e do bom senso de quem realiza a análise.

$\mathrm{Na}$ formulação de BRANSON, a inércia equivalente determinada em função do máximo momento fletor, é constante ao longo de todo elemento, não sendo, portanto, necessária a divisão do modelo em vários elementos.

\subsection{PROCEDIMENTOS EMPREGADOS PARA CONSIDERAR A NÃO-LINEARIDADE}

No início da dissertação, planejou-se fazer análises teóricas de lajes nervuradas formadas por vigotas pré-moldadas com armação em forma de 
treliça. Esta análise consiste na análise não-linear em modelos de grelha mediante o uso da relação momento x curvatura.

Como base do trabalho, tem-se a tese de doutorado do Prof. Roberto Chust Carvalho, sob o título Análise não-linear de pavimentos de concreto armado através da analogia de grelha, CARVALHO (1994).

Com a idéia geral do trabalho já concretizada, optou-se por fazer as análises mediante o emprego do programa ANSYS ${ }^{\circledR 5}$. Como primeiro passo, estudou-se detalhadamente os principais recursos deste programa ( préprocessador, o processamento ou análise estrutural e o pós-processador).

Utilizando este programa e com o modelo de grelha, analisou-se as lajes nervuradas em comportamento linear, sendo a principal vantagem, a facilidade de entrada rápida e modificação dos dados e a visualização dos resultados. Apresenta-se na figura $\mathbf{3 . 1 2}$ o desenho de uma grelha gerada no ANSYS $^{\circledR}$.

NNSYS

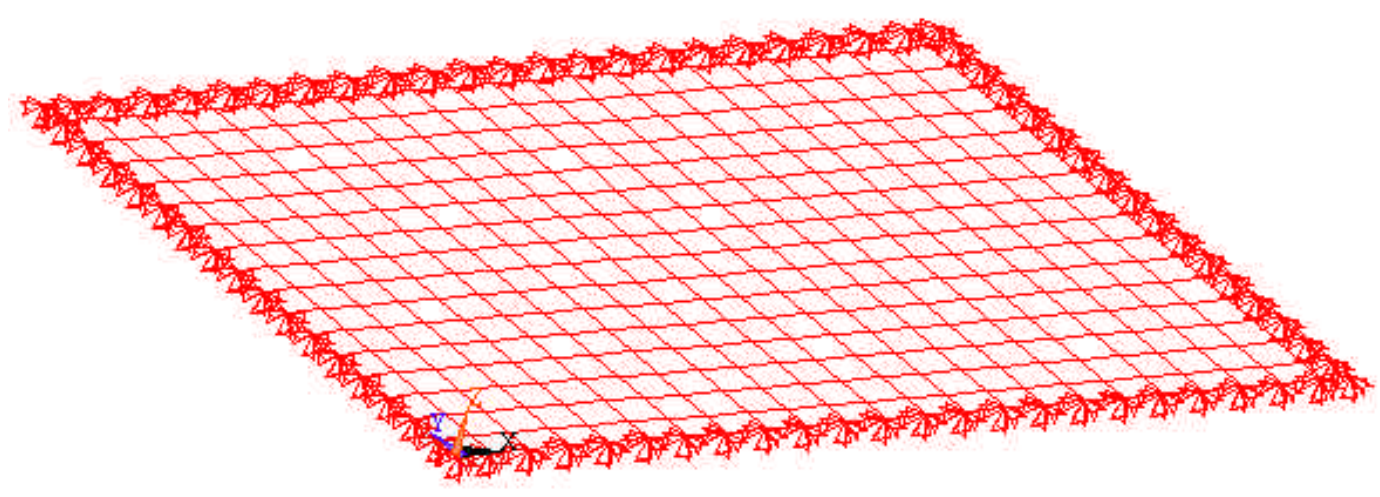

Fig.3.12 Grelha gerada no ANSYS ${ }^{\circledR}$

O elemento adotado para estas análises em vigas e/ou grelhas foi 0 elemento de barra BEAM4-3D Elastic Beam, que faz parte da biblioteca de

\footnotetext{
${ }^{5}$ ANSYS $^{\circledR}$ Analysis System - Release 5.4. (1997)
} 
elementos do ANSYS $^{\circledR}$. Sendo um elemento uniaxial com 6 graus de liberdade em cada nó, ou seja, translação e rotação nas três direções.

Mas, notou-se a possibilidade de realizar a análise não-linear da laje, de acordo com os próprios recursos do ANSYS ${ }^{\circledR}$, pois o mesmo possui em sua biblioteca, o elemento SOLID65 3-D Reinforced Concrete Solid, este elemento simula as características do concreto-armado, inclusive a perda de rigidez devida à fissuração.

Como parte de um trabalho paralelo, para uma posterior comparação com o modelo de grelha, estudou-se as características gerais deste elemento e também os meios da realização da análise não-linear mediante os critérios de convergência e de equilíbrio. Deste modo, a análise não é mais realizada segundo a analogia de grelha, pois a estrutura é modelada como um sólido com as dimensões iguais à estrutura real.

Esta análise não obteve o sucesso esperado, pois devido à grande complexidade da análise não-linear em sólidos e também dos critérios próprios de convergência do programa, optou-se por realizar a análise nãolinear somente com a analogia de grelha.

O processo ou técnica adotada para a realização da análise nãolinear, em modelo de grelha, tendo como base as equações momento $x$ curvatura, foi a do carregamento incremental.

De acordo com CARVALHO (1994) uma primeira vantagem de se considerar o carregamento incremental, está na possibilidade de trabalhar, em cada etapa, com a rigidez próxima da correta. Pode-se considerar que em cada etapa de carga há linearidade entre os esforços e deslocamentos, bastando para tanto considerar um certo número mínimo de etapas. $\mathrm{O}$ problema não linear passa a ser resolvido através de uma soma de parcelas lineares.

Uma técnica mais refinada a se empregar é a que admite para cada etapa de carga, um processo iterativo em que se procura corrigir o erro de haver sido considerada a estrutura linear para o incremento de carga. Deste modo, obtém-se o equilíbrio entre todas as forças externas e internas. 
Dentro das limitações do conhecimento para a programação no ANSYS ${ }^{\circledR}$, e do pouco tempo disponível, esta técnica não foi possível de ser empregada.

Para a realização da análise não-linear, utilizando o programa ANSYS $^{\circledR}$, implementou-se as equações de momento $x$ curvatura e 0 processo para o carregamento incremental. Esta implementação, que modifica o esquema habitual de processamento linear do programa é possível mediante a introdução de "macros" ou sub-rotinas.

A análise não-linear é realizada, após o dimensionamento dos elementos constituintes da grelha. Para o dimensionamento, consideram-se os esforços solicitantes obtidos mediante o emprego da análise linear.

$\mathrm{Na}$ estrutura em estudo (grelha, viga), os valores a se considerar dos esforços serão os obtidos no ponto central do elemento. Com isso, quanto maior for o número de elementos ou divisões em uma viga, por exemplo, melhor será a aproximação ao o diagrama real presente na estrutura. A seguir tem-se na figura 3.13, como exemplo, a determinação dos valores de momento fletor em uma viga bi-apoiada com carregamento distribuído e discretizada em 5 elementos:

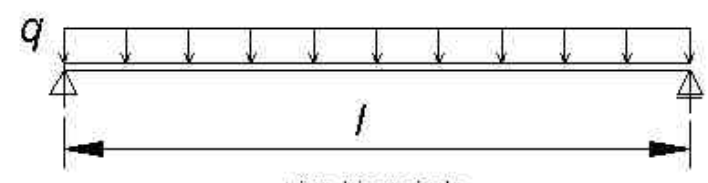

viga bi-apoiada

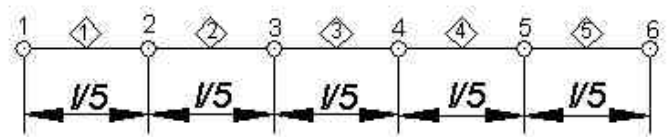

representaçẫo da viga acima

o - nó 'n'

(n) - elemento ' $n$ '
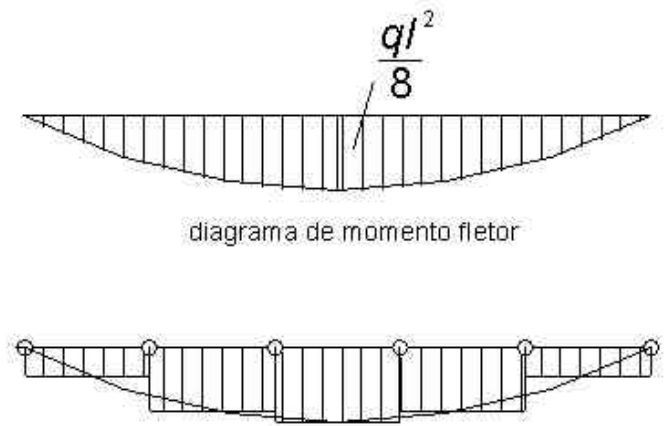

diagrama de momento fletor obtido em função do momento atuante na regiẫo central do elemento

Fig.3.13 Viga bi-apoiada discretizada em 5 elementos 


\section{a) Análise linear}

A análise linear da grelha é realizada, como comentado, mediante 0 uso do programa ANSYS $^{\circledR}$, sendo necessária a definição do carregamento da grelha (peso próprio + sobrecarga) e da rigidez das barras longitudinais e transversais.

Para a rigidez à flexão $\left(K_{f}\right)$ deve-se definir o valor do módulo de elasticidade longitudinal do concreto $\left(E_{c}\right)$ e do momento de inércia à flexão da seção de concreto $\left(I_{o}\right)$ :

$$
k_{f}=E_{c} \cdot I_{o}
$$

Nas análises de grelha geralmente desconsideram-se ou adotam-se valores reduzidos da rigidez à torção, pois esta rigidez, na maior parte dos casos, não é necessária ao equilíbrio estrutural e também há poucos estudos que indiquem o valor da rigidez a se considerar.

Considera-se, a princípio a rigidez à torção no estádio II (para o caso de interação entre os esforços de flexão e de torção), segundo o CEB-90 visto em 3.2.2 sendo expresso por:

$$
k_{\text {TII }}=0,05 \cdot E_{c} \cdot I_{T} K
$$

A análise linear na grelha, como em qualquer outro tipo de estrutura, permite avaliar os esforços solicitantes (momento fletor, momento torçor, cortante), reações de apoio, deformações de deslocamentos.

Os valores de esforços e deslocamentos, através do programa ANSYS $^{\circledR}$ são obtidos via processo dos deslocamentos. 


\section{b) Análise não-linear}

\section{b.1 Valores e a variação da rigidez à flexão}

Como apresentado em 3.3, a variação da rigidez à flexão no elemento se dá em função do valor do momento fletor atuante. Sendo o momento de fissuração $\left(M_{r}\right)$, o momento de escoamento do aço ou plastificação do concreto $\left(M_{y}\right)$ e o momento último $\left(M_{u}\right)$ valores limites que definem o estádio de comportamento do elemento.

Os valores dos momentos e curvaturas de escoamento do aço ou plastificação do concreto e também valores últimos são determinados de acordo com equações de equilíbrio, de compatibilidade e também das equações constitutivas do concreto e do aço. Estas equações são apresentadas no ANEXO A. Para facilitar a determinação destes valores, monta-se uma rotina de cálculo em linguagem FORTRAN ${ }^{6}$, nomeada de RIGIDEZ.

Para o dimensionamento de elementos de concreto armado, considera-se o diagrama tensão x deformação do aço e do concreto, de acordo com a NBR-6118 (1982). Nesta análise, pretende-se avaliar o comportamento da estrutura, e em casos onde não se tem os diagramas experimentais de comportamento do aço e do concreto, consideram-se os mesmos diagramas propostos para o dimensionamento. Mas, os valores de resistência indicados como valores característicos ou de cálculo, são substituídos por valores médios de resistência, como pode ser visto na figura 3.14 .

Segundo o diagrama tensão x deformação do concreto, o patamar de escoamento ocorre com a tensão correspondente à deformação igual a $2 \%$. Mas nota-se que com deformações menores já ocorre uma grande perda de rigidez devido à plastificação do concreto. Devido a isto, considera-se nas análises, para a determinação do momento de escoamento ou plastificação,

\footnotetext{
${ }^{6}$ FORTRAN - Microsoft Developer Studio - Fortran Powerstation 4.0 (1995)
} 
o valor de deformação do concreto igual a $2 \%$ e 1,5\%, para comparações.

Com o aço classe B ocorre o mesmo, é definido o escoamento do aço a tensão igual a $f_{y m}$, mas, como é visto no seu diagrama tensão $x$ deformação, a partir da tensão igual a $0,7 f_{y m}$ há perda de rigidez. Para este trabalho, considera-se a tensão de escoamento no aço tipo B um valor intermediário entre 0,7 e 1,0 $f_{y m}$. A princípio considera-se o valor médio 0,85 $f_{y m}$. O escoamento do aço tipo A, como é visto no seu diagrama é igual a $1,0 f_{y m}$.

O valor do momento de escoamento $\left(M_{Y}\right)$ calculado no início do patamar de escoamento é diferente do valor do momento de escoamento calculado no arbitrado início da plastificação ou perda de rigidez. Com a consideração de valores diferentes de momento de escoamento na formulação do CEB-90, os valores de deslocamento e curvatura, serão diferentes, sendo estes valores analisados no decorrer do trabalho, mediante a comparação de análises teórica e experimental.

Desta forma pretende-se considerar a queda de rigidez não somente a partir do escoamento, e sim a partir de um dado ponto da curva (tensão $x$ deformação) em que já ocorra uma grande perda de rigidez.

Ainda, para o uso do Modelo do CEB-90 (1991), necessita-se da determinação da rigidez à flexão $\left(k_{f}\right)$ para os estádios I e II.

Conforme visto em 3.3, considera-se o valor do módulo de elasticidade igual à $E_{c}$ e $E_{c s}$, para os estádios I e II, respectivamente.

Os valores de momento de inércia à flexão para o estádio I e estádio II puro são obtidos através da homogeneização da seção, de acordo com a razão entre os módulos de elasticidade do aço e do concreto $(\alpha)$.

$$
\alpha=\frac{E_{s}}{E_{c}}
$$




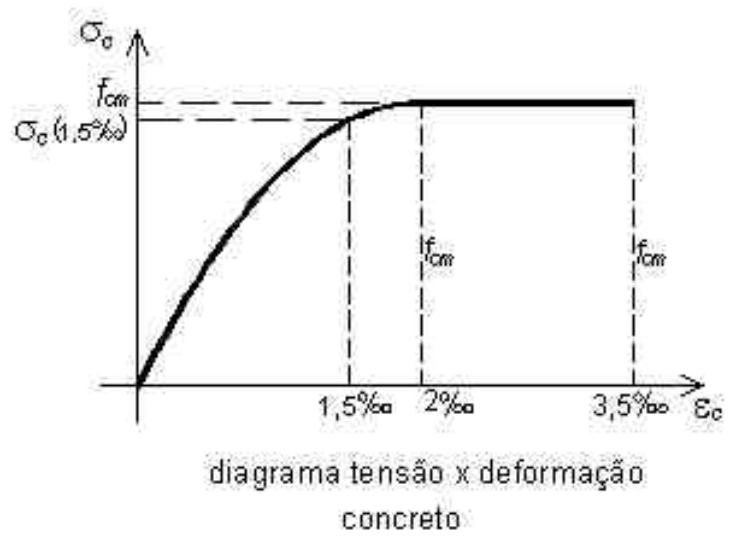

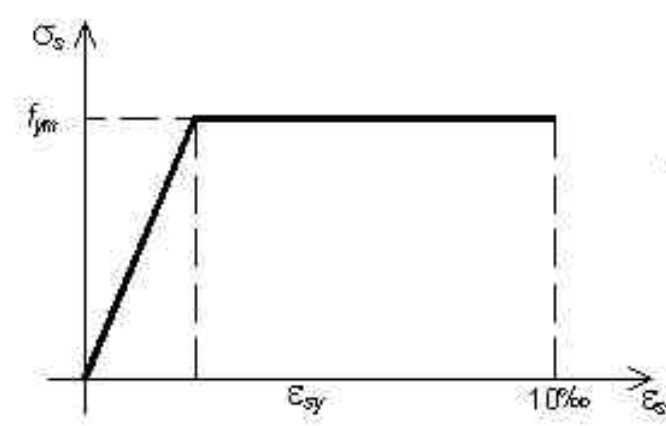

diagrama tensẫo $x$ deformaçẫo aço CA-50 A

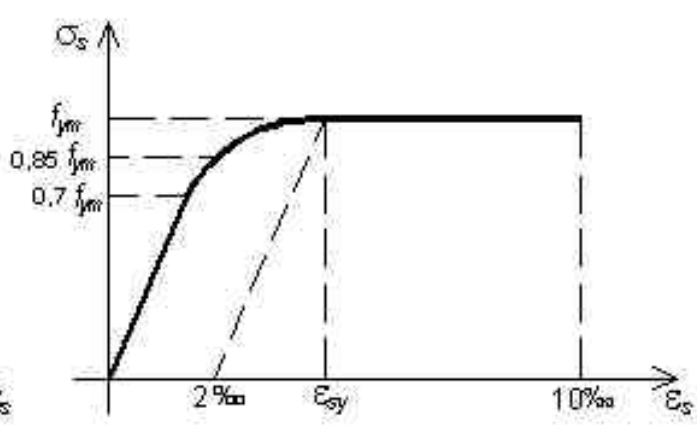

diagrama tensầo $\mathrm{x}$ de formaçẫo aço CA-60 B

Fig.3.14 Diagrama tensão $x$ deformação - concreto e aço

Sabe-se que para a determinação do momento de inércia à flexão para o estádio II puro, considera-se apenas a região comprimida de concreto, como pode ser visto na figura 3.15.

Apresenta-se na figura $\mathbf{3 . 1 6}$ a variação da rigidez à flexão em função do momento fletor atuante em um elemento para as equações do CEB-90 e da função proposta por BRANSON. O artifício considerado nas análises segundo BRANSON consiste em atribuir o valor do momento de inércia, calculado em função do maior momento fletor atuante, a todos os elementos, ou seja, todos os elementos possuem a mesma rigidez à flexão. 


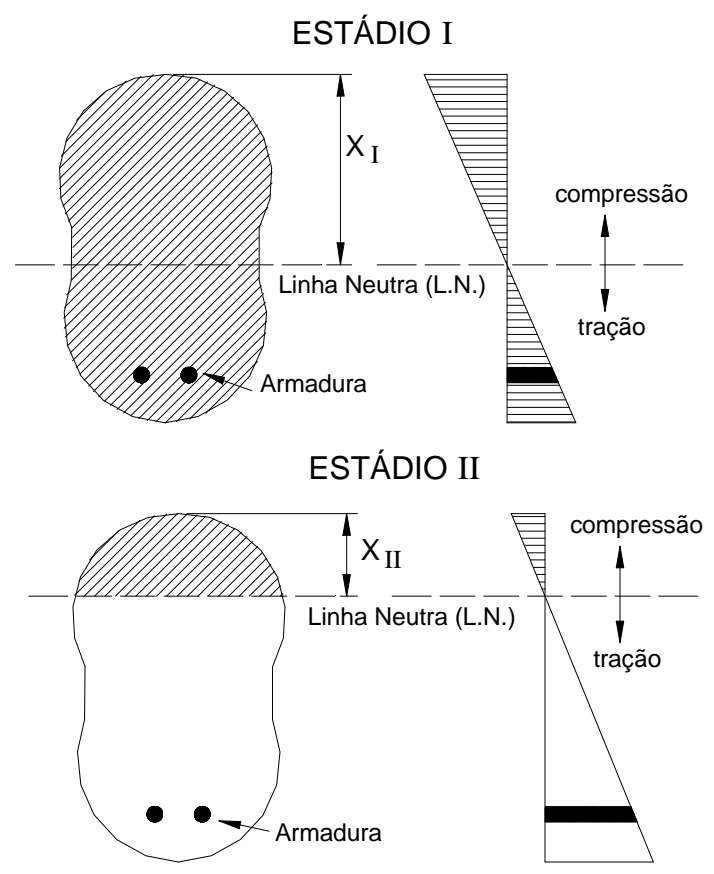

Fig.3.15 Momento de inércia - estádio I e II

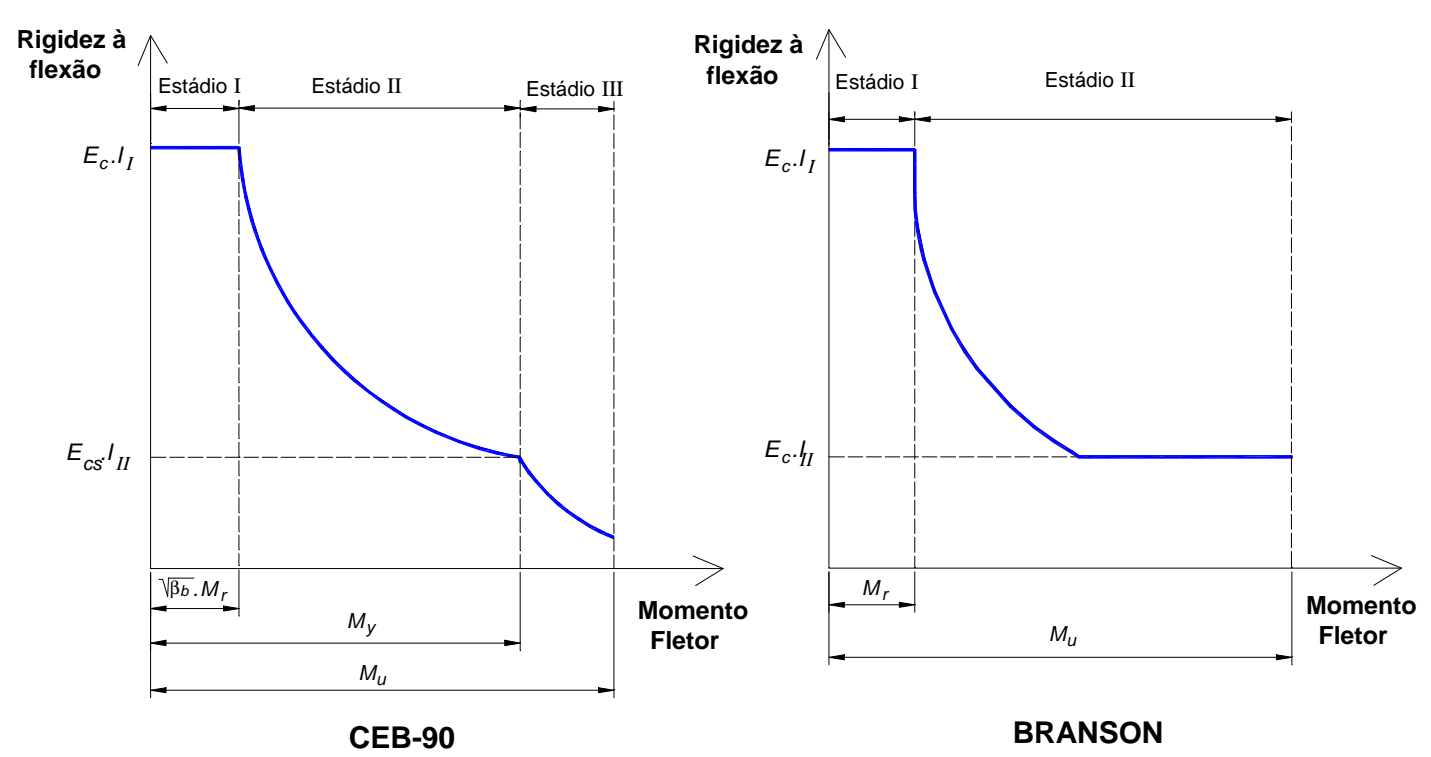

Fig.3.16 Variação da rigidez à flexão

Em função do valor da curvatura e do momento fletor em uma seção, pode-se calcular a rigidez à flexão. Lembrando que os valores de curvatura são calculados em função de equações de equilíbrio e de compatibilidade de 
deformações. Deste modo, o cálculo da rigidez não será função direta do módulo de elasticidade nem tampouco do momento de inércia.

Considerando-se o início do escoamento a partir do estádio II puro, pode-se determinar a rigidez à flexão no estádio II $\left(k_{f I I}\right)$ através dos valores de momento $\left(M_{y}\right)$ e curvatura de escoamento $\left(1 / r_{y}\right)$ :

Sendo, $\quad \frac{1}{r_{y}}=\frac{M_{y}}{E_{c s} I_{\mathrm{II}}} \quad$ tem-se $\quad E_{c s} I_{\mathrm{II}}=k_{f \mathrm{II}}=\frac{M_{y}}{\frac{1}{r_{y}}}$

Conclui-se, portanto, que a rigidez no estádio II pode ser calculada pela homogeneização da seção (função dos módulos de elasticidade dos materiais) ou de acordo com a curvatura (função das equações de equilíbrio, equações de compatibilidade e também das equações constitutivas do concreto e do aço). Apresenta-se no ANEXO B comparações de valores de rigidez à flexão para o estádio I e II segundo a homogeneização da seção e da relação momento $x$ curvatura.

\section{b.2 Rigidez à torção}

Nesta análise não-linear considera-se os valores de rigidez à torção no estádio I e II, conforme visto em 3.2.2.

$K_{T I}=0,3 . E_{c} \cdot I_{T}$ - coeficiente de rigidez à torção no estádio I

$K_{T \text { II }}=0,05 \cdot E_{c} \cdot I_{T}$ - coeficiente de rigidez à torção no estádio II

O estudo do comportamento de elementos submetidos à torção é feito aqui de forma dependente dos esforços de flexão. Pois como não se tem um estudo detalhado dos momentos torçores limitantes para a determinação do estádio em que se encontra o elemento, estes limites são, então, adotados em função dos momentos fletores. A maioria dos ensaios disponíveis na 
literatura está relacionada à torção simples e são adotados como aproximação para os casos de solicitação composta.

Para valores acima do momento de escoamento ou plastificação, não se tem indicação do valor da rigidez à torção, supondo ser um valor muito baixo, considera-se um valor próximo de zero.

Na figura 3.17 representa-se a variação da rigidez à torção em função do momento fletor atuante no elemento.

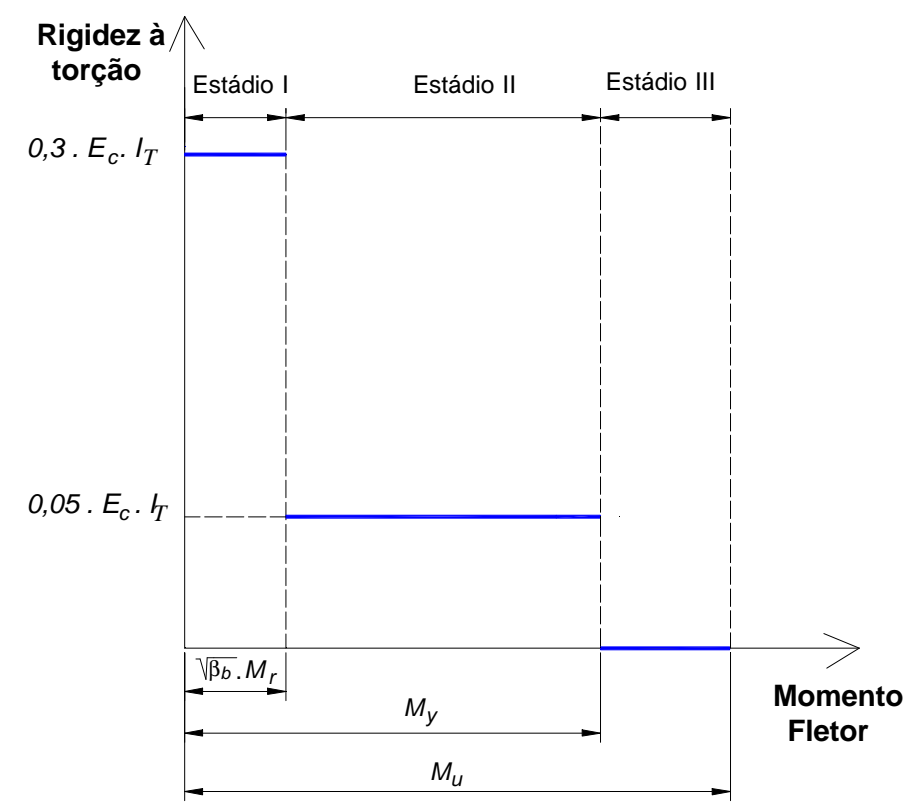

Fig.3.17 Variação da rigidez à torção

\section{b.3) Carregamento incremental}

A técnica adotada para considerar a não linearidade física é a do carregamento incremental. O carregamento em uma estrutura pode ser obtido pela soma de $n$ etapas ou incrementos de carga. Pode-se considerar que em cada etapa de carga, há linearidade entre esforços e deslocamentos, ou seja, o problema não linear passa, assim, a ser resolvido através da soma de parcelas lineares. 
A rigidez (à flexão ou à torção) de cada elemento em um dado incremento de carga será, portanto, função do valor do momento fletor decorrente da etapa anterior adicionada ao valor proveniente do incremento de carga. Com o novo valor da rigidez e das forças externas aplicadas na estrutura, calculam-se através de análise linear os esforços e deslocamentos.

A seguir, tem-se na figura 3.18, como exemplo, um diagrama de carga $\mathrm{x}$ deslocamento considerando a mudança de rigidez de um certo elemento. De acordo com esta figura, tem-se que com o incremento de carga 3 ocorre a mudança de rigidez, pois ultrapassa o ponto de início da fissuração.

Para o incremento 4 reduz-se mais ainda a rigidez, pois se tem um maior esforço solicitante.

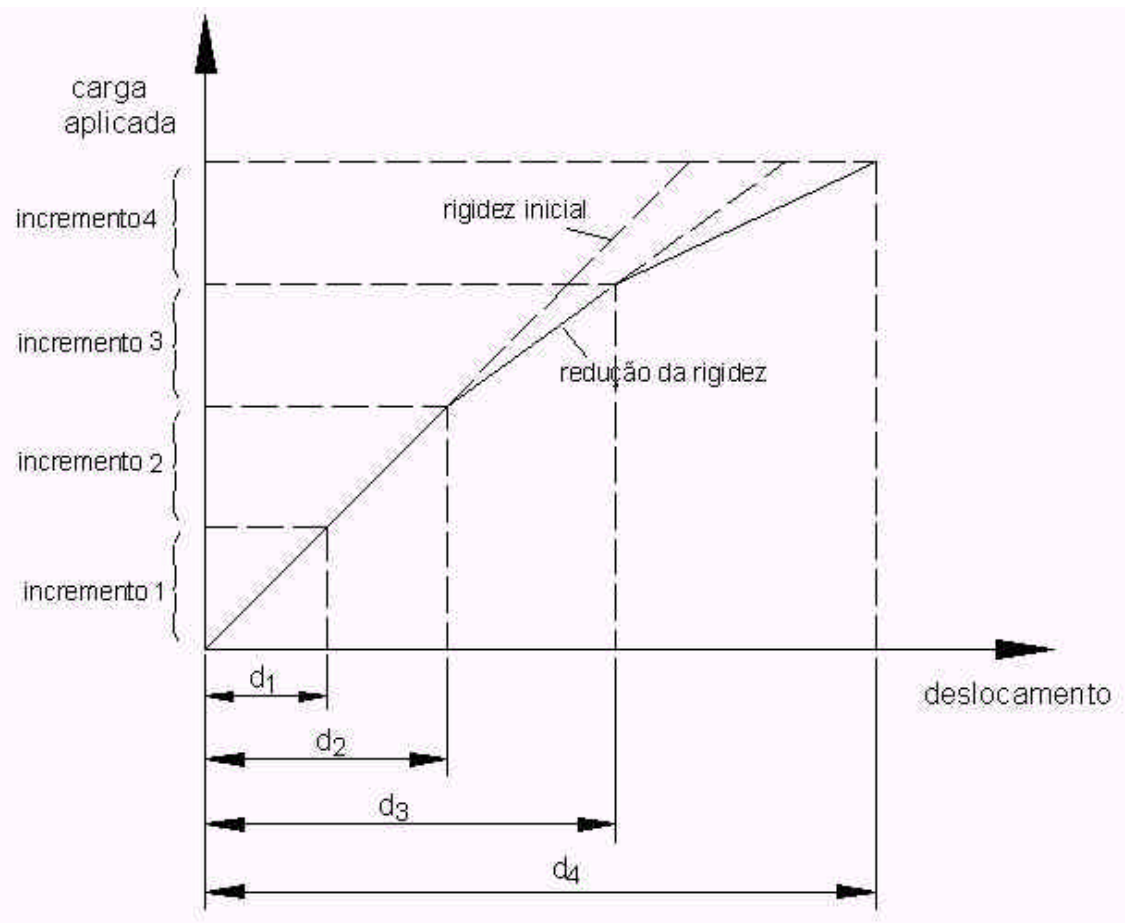

Fig.3.18 Diagrama genérico de carga $\mathrm{x}$ deslocamento 
Sintetizando o procedimento utilizado para a análise não-linear, temse:

- Determinação dos esforços mediante análise linear;

- Dimensionamento dos elementos;

- Cálculo das características geométricas e mecânicas dos elementos mediante o uso do programa RIGIDEZ, realizado em linguagem FORTRAN;

- Introdução dos valores obtidos como dados de entrada nos "macros" do ANSYS ${ }^{\circledR}$;

- Análise não-linear incremental;

- Saída e análise dos resultados.

$\mathrm{Na}$ figura a seguir, mostra-se um fluxograma do esquema de resolução adotado para a consideração da não-linearidade.

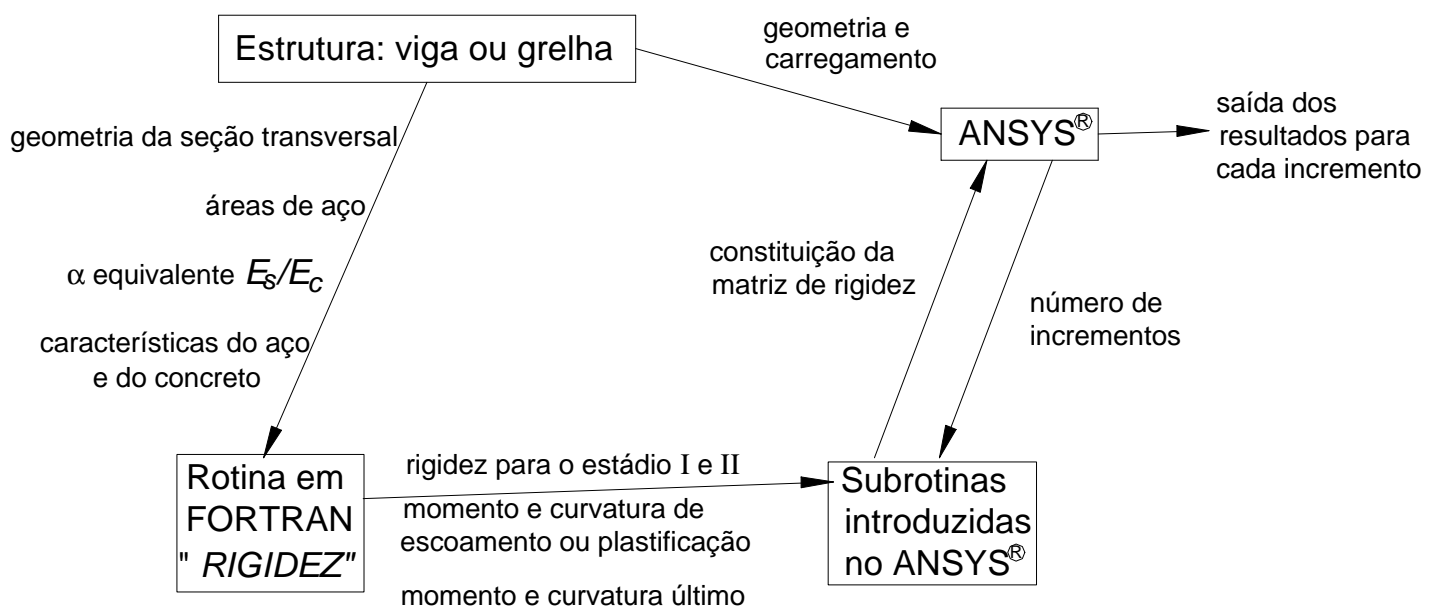

Fig.3.19 Fluxograma da análise não-linear 


\subsection{PARTICULARIDADES DO PROCEDIMENTO}

\subsubsection{CONTINUIDADE}

Entre lajes pré-moldadas adjacentes, como acontece com as lajes maciças, há a continuidade estrutural. Com isso há uma diminuição do momento fletor positivo e aparece o momento fletor negativo. Apresenta-se na figura 3.20 o diagrama de momento fletor sem a consideração da continuidade e com a consideração da continuidade.

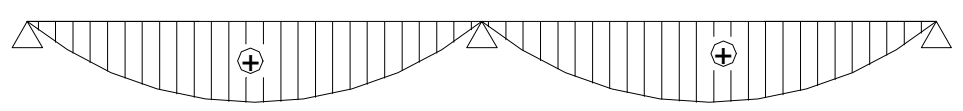

lajes simplesmente apoiadas

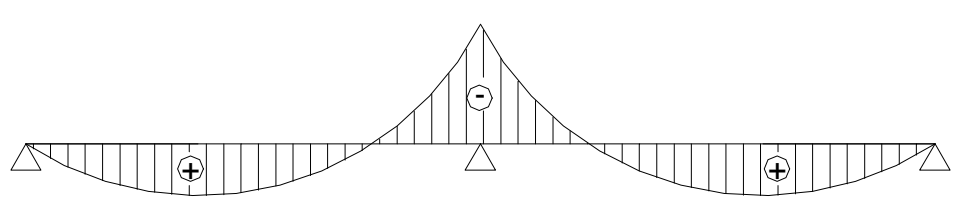

lajes contínuas

Fig.3.20 Diagrama de momento fletor para lajes simplesmente apoiadas e lajes contínuas

Atenção especial deve ser dada às lajes nervuradas contínuas. Nos apoios intermediários, onde atua 0 momento fletor negativo, a seção resistente é formada apenas pela alma das nervuras, com largura $b_{w}$ (figura 3.21). As quais funcionam, como vigas de seção retangular, pois, neste caso, em geral, toda a mesa está na zona tracionada.

Lembra-se que o momento fletor negativo não aparece somente nos casos de continuidade, mas também em situações em que se considera a rigidez à torção das vigas de extremidade. 


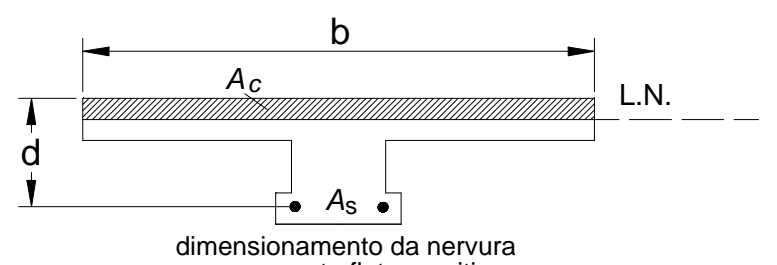

ao momento fletor positivo

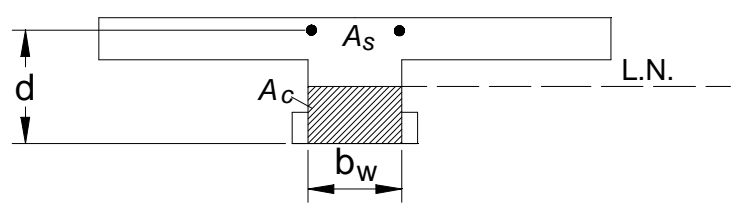

dimensionamento da nervura

ao momento fletor negativo

$A_{C}=$ área de concreto

$A_{\mathrm{S}}=$ área de aço

Fig.3.21 Dimensionamento da nervura - mesa comprimida e tracionada

A análise não linear com continuidade se dá do mesmo modo que para as lajes e vigas simplesmente apoiadas. A única diferença é a rigidez (à flexão e à torção). Neste caso tem-se uma matriz de rigidez dupla, ou seja, para cada incremento de carga, calcula-se a rigidez correspondente em função do valor absoluto (positivo ou negativo) do momento fletor atuante no elemento. Se o momento fletor for positivo, determina-se a rigidez em função da seção transversal dimensionada para resistir ao momento fletor positivo, caso contrário, determina-se a rigidez em função da seção transversal dimensionada ao momento fletor negativo, como pode ser visto na figura 3.22 .

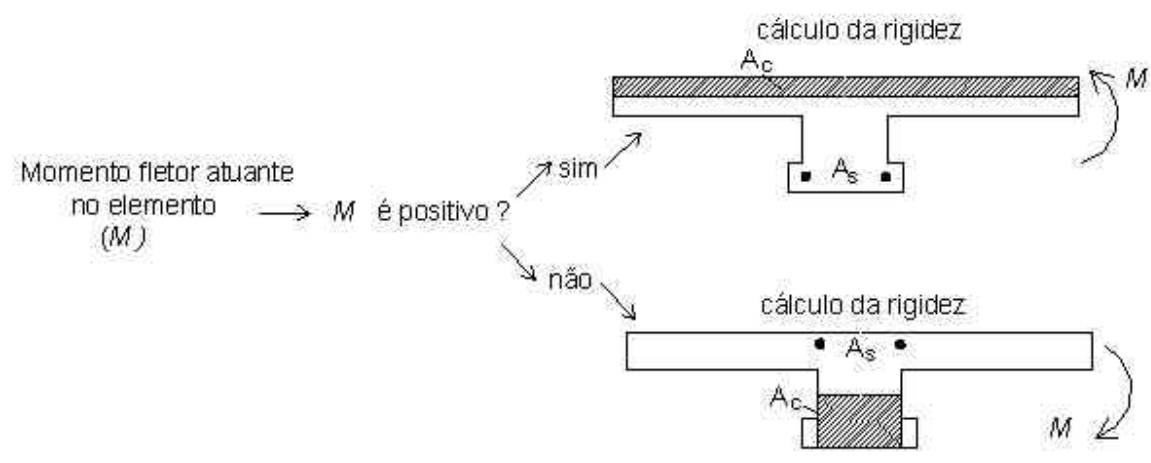

Fig.3.22 Análise não-linear - momento fletor positivo e negativo 


\subsubsection{CONTRIBUIÇÃO DA CAPA DE CONCRETO}

Nas lajes unidirecionais, considera-se a contribuição da capa de concreto na direção transversal (fig.3.23). $\mathrm{Na}$ análise linear considera-se a rigidez (à flexão e à torção) em função da sua geometria (altura da capa de concreto e largura da malha da grelha).

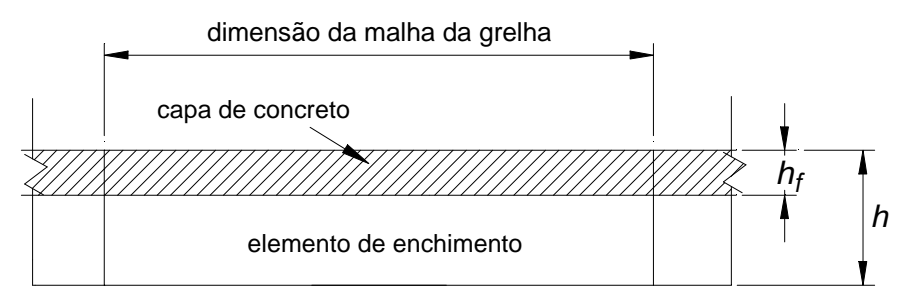

Fig.3.23 Contribuição da capa de concreto na direção transversal

Para a análise-não linear, considera-se a redução da rigidez a partir do início de fissuração da seção em questão.

A rigidez à torção a ser considerada quando se ultrapassa o início de fissuração será a rigidez do estádio II. Agora, para a rigidez à flexão, considera-se a inércia do estádio II igual a $1 / 3$ da inércia à flexão do estádio I. Esta simplificação é feita pelo fato de que nas análises não é considerado o efeito das armaduras de distribuição posicionadas no interior da capa de concreto. 


\section{AVALIAÇÃO DO PROCEDIMENTO EMPREGADO PARA A ANÁLISE NÃO-LINEAR}

\subsection{CONSIDERAÇÕES INICIAIS}

Com o intuito de comparar os valores experimentais com os valores dos modelos teóricos, descrevem-se algumas vigas e lajes de concreto armado ensaiadas no laboratório de estruturas da Escola de Engenharia de São Carlos - USP. Os ensaios apresentados não foram executados pelo autor desta dissertação.

Ressalta-se que nestas comparações teórico-experimental não há análises em lajes pré-moldadas, pois neste deseja-se apenas avaliar 0 modelo teórico apresentado no Capítulo 3.

O capítulo é dividido em duas partes, sendo:

a) análise experimental em vigas bi-apoiadas com seção transversal retangular e "I" ;

b) análise experimental em faixas de lajes contínuas. 


\subsection{VIGAS BI-APOIADAS}

Os ensaios foram feitos em vigas simplesmente apoiadas submetidas a cargas concentradas nos terços e com isso o terço central da viga fica submetido a um estado de flexão simples e pura.

Descreve-se a seguir o ensaio, resultados e comparações teóricas $x$ experimentais de dois tipos de vigas, sendo duas vigas com seção "I" e três com seção retangular. As vigas com seção "I" foram ensaiadas nas aulas de Análise Experimental de Estruturas - SET 816 do Departamento de Engenharia de Estruturas da Escola de Engenharia de São Carlos, e as vigas com seção retangular fazem parte da dissertação de mestrado de ÁLVARES (1993).

\subsubsection{DESCRIÇÃO DOS ENSAIOS}

\section{A) Vigas com seção "I"}

Nas figuras 4.1 e 4.2 mostram-se o esquema de ensaio, a seção transversal e a instrumentação utilizada.

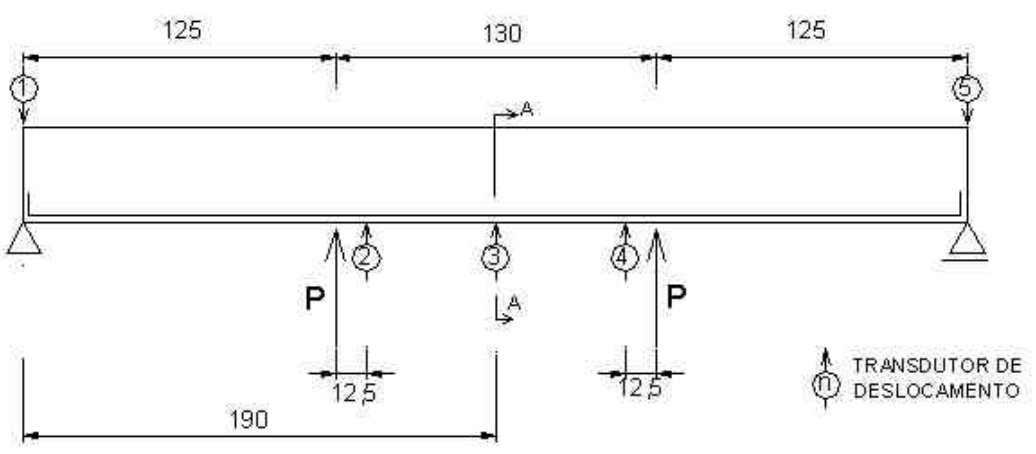

Fig.4.1 Esquema de ensaio da viga "I" e instrumentação (dimensões em cm) 

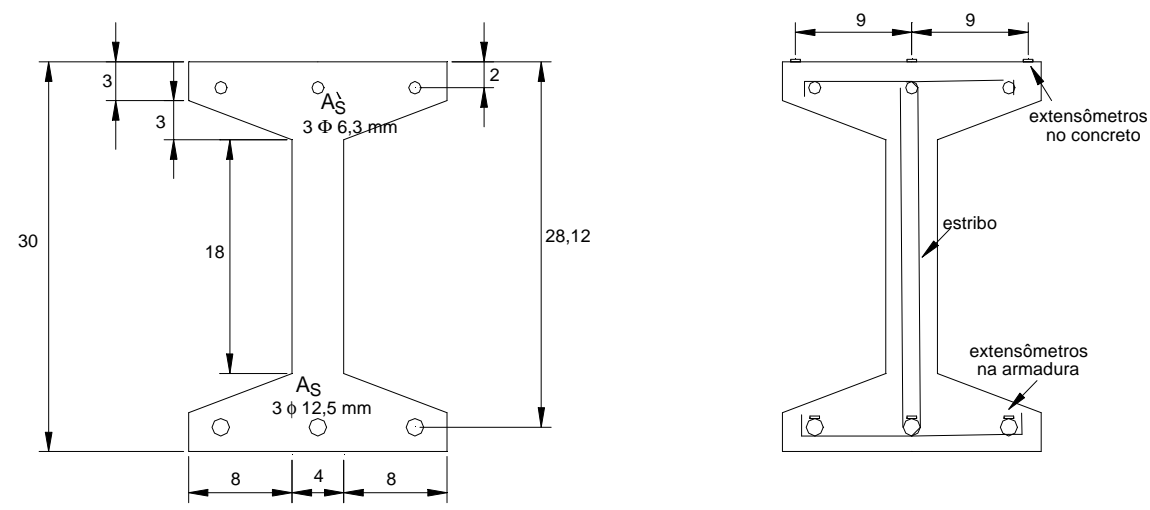

Fig.4.2 Seção transversal da viga "I" e instrumentação

(dimensões em cm)

As vigas com seção "I" possuem concreto com resistências distintas, pois não foram moldadas no mesmo dia. Divide-se, portanto estas vigas em série $A .1$ e série $A .2$.

\section{Série A.1}

Os valores da resistência à compressão e à tração do concreto foram obtidos de ensaios realizados em corpos de prova cilíndricos. Os valores médios obtidos para $f_{c m}$ e $f_{c t m}$ são, respectivamente 24,25 MPa e 2,44 MPa. O valor do módulo de elasticidade foi determinado em dois corpos-de-prova, mas devido a problemas de leitura, o valor considerado é apenas de um corpo-de-prova, sendo igual a $32 \mathrm{GPa}$ com $f_{c m}$ igual a 25,54 $\mathrm{MPa}$. O aço empregado é o CA-50 A.

\section{Série A.2}

Conforme a série anterior tem-se para $f_{c m}$ e $f_{c t m}$, respectivamente, 33,3 MPa e 2,6 MPa. Para este ensaio não foi medido o módulo de elasticidade e também se mediu somente o deslocamento no meio da viga, enquanto que na série A.1 mediu-se também os deslocamentos próximos aos pontos de aplicação da carga, como pode ser visto na figura 4.1. 


\section{B) Vigas com seção retangular}

Como pode ser visto em ÁLVARES (1993), tem-se 3 séries de 2 vigas cada, com a mesma seção transversal, variando-se apenas a taxa de armadura longitudinal junto à face inferior. Apresenta-se o esquema do ensaio na figura 4.3 e a seção transversal das séries na figura 4.4.

Os valores do módulo de elasticidade, resistência à compressão e a tração do concreto foram obtidos de ensaios realizados em corpos de prova cilíndricos de amostras do concreto utilizado nas vigas. Obteve-se o valor de $E_{c}$ igual a $29200 \mathrm{MPa}$. Para $f_{c m}$ e $f_{c t m}$ tem-se, respectivamente 24,0 e 2,68 MPa. O aço empregado é o CA-50 A.

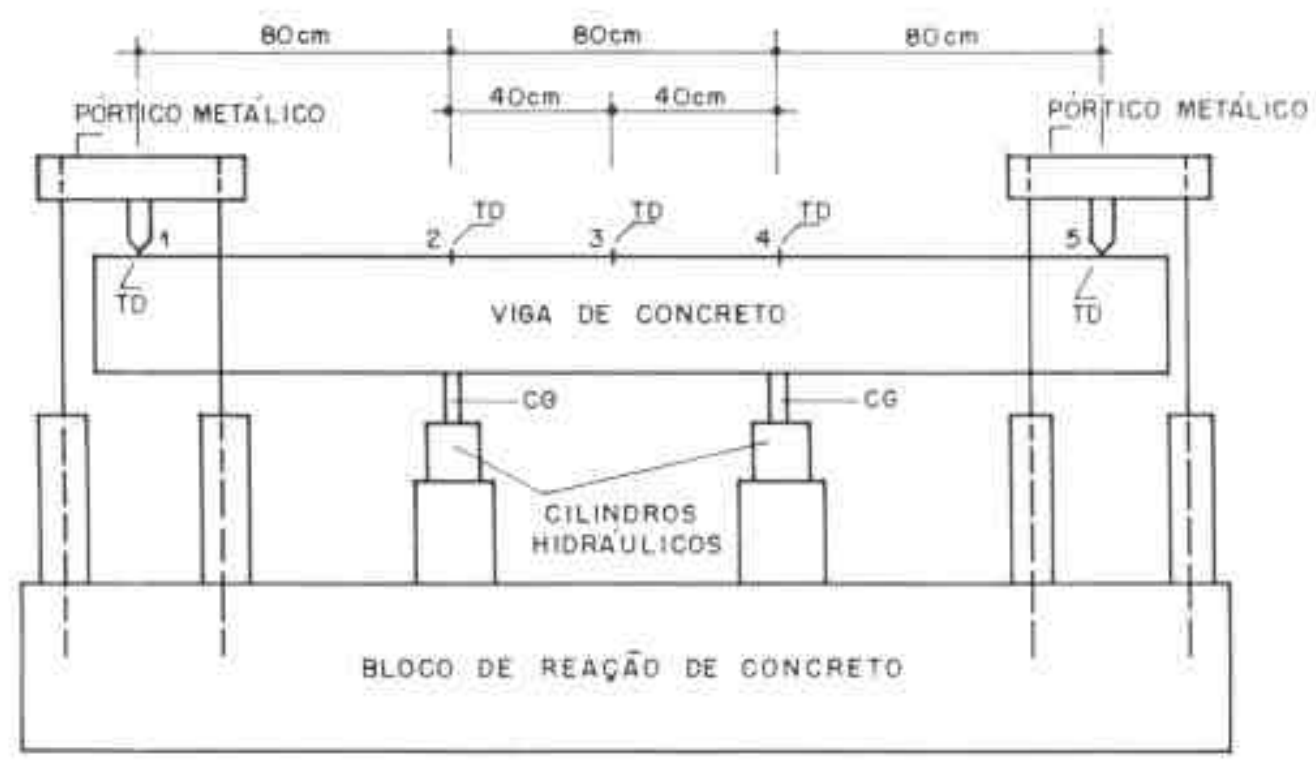

Fig.4.3 Esquema do ensaio das vigas com seção retangular 

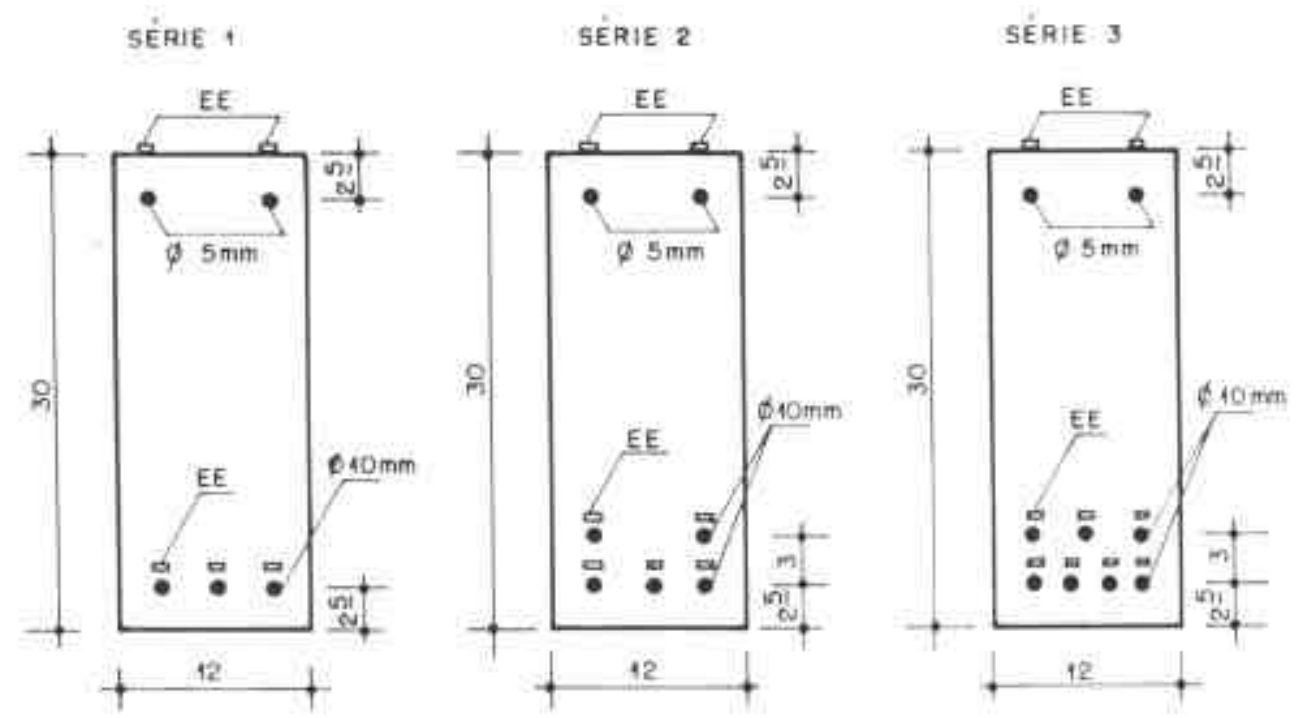

Fig.4.4 Seção transversal das vigas - dimensões em cm

\subsubsection{MODELO ADOTADO E COMPARAÇÕES COM VALORES EXPERIMENTAIS}

\section{A) Vigas com seção "I"}

Pelo fato de que somente na série A.1 determinou-se o módulo de elasticidade e em somente um corpo de prova obteve-se um valor satisfatório utiliza-se o valor do módulo de elasticidade obtido de acordo com o CEB-90 (1991):

$$
\begin{array}{lll}
\text { série A.1 }-E_{c}=28880 \mathrm{MPa} ; & E_{c S}=24550 \mathrm{MPa} \\
\text { série A.2 }-E_{c}=32100 \mathrm{MPa} ; & E_{c S}=27290 \mathrm{MPa}
\end{array}
$$

Adotam-se dois valores de deformação para considerar o início de plastificação do concreto $\left(\varepsilon_{c p}\right)$, sendo igual a $1,5 \%$ e $2 \%$. Mas devido às equações de equilíbrio, obtém-se o mesmo valor de momento e curvatura, 
pois ocorre o escoamento do aço. Para esta análise a variável $\beta_{b}$ é igual a 0,8 .

Utilizando-se o programa RIGIDEZ, desenvolvido em linguagem de programação FORTRAN, tem-se os valores das características geométricas e mecânicas na tabela 4.1 para as séries A.1 e A.2.

Define-se o número de incrementos e também o número de divisões ou elementos na viga, e de posse dos valores de rigidez, momentos e curvaturas, executa-se o programa ANSYS ${ }^{\circledR}$, juntamente com os "macros" aí introduzidos.

Adota-se o incremento da força aplicada igual a $1,0 \mathrm{kN}$, sendo 0 número de iterações função do momento último, pois, tratando-se de uma viga isostática a relação da força aplicada e momento atuante é linear.

O número de nós e elementos para esta análise são respectivamente 31 e 30 , sendo $13,0 \mathrm{~cm}$ o comprimento de cada elemento do terço central da viga e os demais elementos com $12,5 \mathrm{~cm}$ de comprimento.

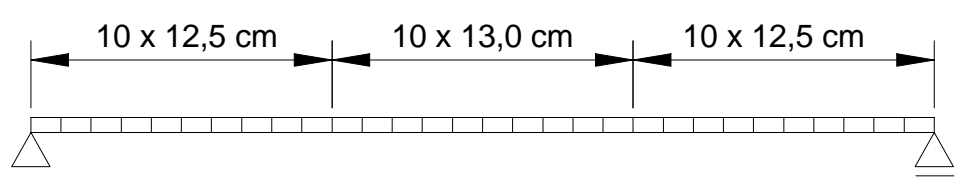

Fig.4.5 Divisão da viga "I" em elementos 
Tabela 4.1 Características geométricas e mecânicas - viga "I"

\begin{tabular}{|c|c|c|}
\hline série & A.1 & A.2 \\
\hline As & 3,80 & 3,80 \\
\hline As2 & 0,94 & 0,94 \\
\hline$X_{0}$ & 15 & 15 \\
\hline 10 & 32400 & 32400 \\
\hline$X_{I}$ & 15,81 & 15,71 \\
\hline$I_{I}$ & 37330 & 36724 \\
\hline$X_{I I}$ & 7,86 & 7,43 \\
\hline$I_{I I}$ & 14625 & 13326 \\
\hline$\overline{M r}$ & 770,2 & 802 \\
\hline Escoamento ou plastificação & ARMAD & ARMAD \\
\hline$M y$ & 4886,76 & 4927,97 \\
\hline $1 / r y$ & 0,00013 & 0,00012 \\
\hline$X_{y}$ & 9,62 & 7,99 \\
\hline Momento fletor último & DOM2B & DOM2A \\
\hline$M u$ & 4985,2 & 5042,1 \\
\hline $1 / r u$ & 0,00043 & 0,00042 \\
\hline$X_{u}$ & 4,98 & 4,18 \\
\hline RIGIDEZ (1) estádio II & 35903570 & 36367320 \\
\hline RIGIDEZ (2) estádio II & 37968073 & 41668184 \\
\hline Diferença \% & 5,44 & 12,72 \\
\hline
\end{tabular}

RIGIDEZ (1) estádio II - Obtida pela homogeneização da seção RIGIDEZ (2) estádio II - Obtida pela relação momento x curvatura

Sendo:

$A_{s}, A_{s 2}$ - Área da seção transversal da armadura $\left(\mathrm{cm}^{2}\right)$ comprimida e tracionada, respectivamente;

$X_{0}, X_{I}, X_{I I}$ - Posição da linha neutra $(\mathrm{cm})$ para a seção de concreto sem armadura, para o estádio I e para o estádio II, respectivamente;

$I_{0}, I_{I}, I_{I I}$ - Momento de inércia à flexão $\left(\mathrm{cm}^{4}\right)$ para a seção de concreto sem armadura, para o estádio I e para o estádio II;

$M_{u}, M_{y}, M_{u}$ - Momento fletor (kN.cm) de início de fissuração, de plastificação e último;

$1 / r_{y}, 1 / r_{u}$ - Curvatura $\left(\mathrm{cm}^{-1}\right)$ referente ao momento de plastificação e momento último.

Utiliza-se na análise, a rigidez à flexão para o estádio II, calculada pela relação momento x curvatura, sendo a RIGIDEZ (2) vista na tabela 4.1. 
Através dos resultados experimentais pode-se calcular o valor da curvatura no trecho em que o momento é constante (flexão pura). Calcula-se a curvatura por dois métodos:

\section{1) cálculo da curvatura média em função dos deslocamentos :}

Supõe-se que a viga entre os pontos 2 e 4 (figura 4.6), após deformarse tem sua elástica representada por um arco de círculo, assim a curvatura média fica dada por:

$$
\frac{1}{r}=\frac{2 f}{\left(\frac{b}{2}\right)^{2}+f^{2}} \quad \text { sendo, } \quad f=d_{3}-\left(\frac{d_{2}+d_{4}}{2}\right)
$$

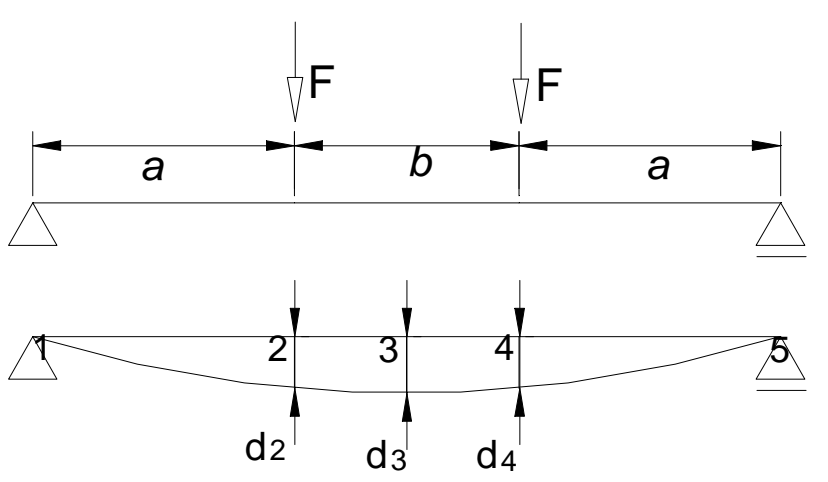

$d$ - deslocamento

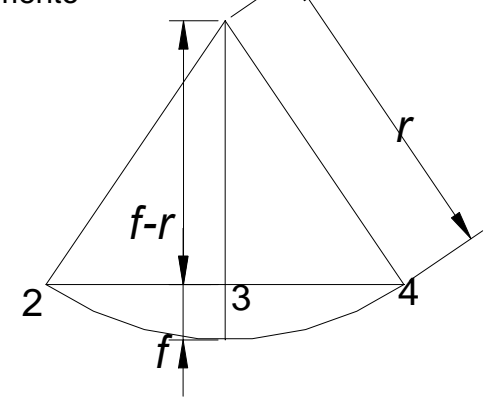

Fig.4.6 Determinação da curvatura média

2) cálculo da curvatura em função das deformações:

Para diferenciar da curvatura mencionada no item a), chamaremos esta apenas de curvatura. O cálculo desta por meio de resultados 
experimentais necessita dos valores de deformação do aço $\left(\varepsilon_{s}\right)$ e do concreto $\left(\varepsilon_{c}\right)$, sendo dado por:

$$
\frac{1}{r}=\frac{\left|\varepsilon_{c}\right|+\varepsilon_{s}}{d}
$$

De acordo com os valores experimentais de deformação no aço e concreto determina-se a curvatura experimental. Os valores teóricos da curvatura são obtidos em função das equações de curvatura do modelo do CEB-90 (1991).

\section{B) Vigas com seção retangular}

Série B. 1 , B.2 e B.3 $-E_{c}=29200 \mathrm{MPa} \quad ; \quad E_{c S}=24820 \mathrm{MPa}$

Adotam-se dois valores para considerar o início de plastificação do concreto $\left(\varepsilon_{c p}\right)$, sendo igual a $1,5 \%$ e $2 \%$.

Em função do centro de gravidade das armaduras tracionadas, calcula-se a altura útil ( $d$ ) obtendo:

série B. $1-A_{s}=2,4 \mathrm{~cm}^{2} ;$ taxa de armadura $=0,67 \% ; d=27,5 \mathrm{~cm}$ série B.2- $A_{s}=4,0 \mathrm{~cm}^{2} ;$ taxa de armadura $=1,11 \% ; \quad d=26,3 \mathrm{~cm}$ série B.3 - $A_{s}=5,6 \mathrm{~cm}^{2} ;$ taxa de armadura $=1,56 \% ; \quad d=26,2 \mathrm{~cm}$

Com o programa RIGIDEZ, tem-se para as séries B.1, B.2 e B.3 os valores das características geométricas e mecânicas na tabela 4.2.

Adota-se o incremento da força $F$ igual a $1,0 \mathrm{kN}$, o número de nós e elementos para esta análise são respectivamente 31 e 30 , sendo cada elemento com comprimento igual a $8,0 \mathrm{~cm}$.

Para a análise segundo o CEB-90, $\beta_{b}$ é igual a 0,8. 
Tabela 4.2 Características geométricas e mecânicas - viga retangular

\begin{tabular}{|c|c|c|c|c|c|}
\hline Série & B.1 & \multicolumn{2}{|c|}{ B.2 } & \multicolumn{2}{c|}{ B.3 } \\
\hline Deformação de plastif. do concr. (/1000) & 1,5 e 2,0 & 1,5 & 2 & 1,5 & 2 \\
\hline$A s$ & 2,4 & 4 & - & 5,6 & - \\
\hline$A s 2$ & 0,4 & 0,4 & - & 0,4 & - \\
\hline$X_{0}$ & 15 & 15 & - & 15 & - \\
\hline$I_{I}$ & 27000 & 27000 & - & 27000 & - \\
\hline$X_{I}$ & 15,41 & 15,64 & - & 15,9 & - \\
\hline$X_{I I}$ & 29649 & 30394 & - & 31420 & - \\
\hline$I_{I}$ & 7,46 & 8,97 & - & 10,21 & - \\
\hline$M r$ & 8661 & 11640 & - & 14714 & - \\
\hline My plastificação & 816,9 & 851,1 & - & 896 & - \\
\hline $1 / r y$ & $\mathrm{ARMAD}$ & $\mathrm{CONCR}$ & $\mathrm{ARMAD}$ & $\mathrm{CONCR}$ & $\mathrm{CONCR}$ \\
\hline$X y$ & 2935,34 & 4123,19 & 4481,04 & 4512,98 & 5505,53 \\
\hline Escoamento ou & 0,00013 & 0,00014 & 0,00015 & 0,00012 & 0,00016 \\
\hline Mu útimo & 8,73 & 10,71 & 10,87 & 12,09 & 12,57 \\
\hline$X_{u}$ & $\mathrm{DOM} 2 \mathrm{~B}$ & $\mathrm{DOM3}$ & - & $\mathrm{DOM} 3$ & - \\
\hline Momento fletor & 3050,2 & 4631,2 & - & 6079,9 & - \\
\hline RIGIDEZ (2) estádio II & 0,00045 & 0,00045 & - & 0,00031 & - \\
\hline Diferença \% & 5,28 & 7,73 & - & 11,15 & - \\
\hline & 21497420 & 28891040 & 28891040 & 36519580 & 36519580 \\
\hline & 23146619 & 29450593 & 29039816 & 36371603 & 34610542 \\
\hline & 7,12 & 1,9 & 0,51 & 0,41 & 5,52 \\
\hline
\end{tabular}

RIGIDEZ (1) estádio II - Obtida pela homogeneização da seção

RIGIDEZ (2) estádio II - Obtida pela relação momento x curvatura

Nas figuras a seguir (figura 4.7 a 4.12) mostram-se a variação dos valores da curvatura, da rigidez e deslocamento em função da força aplicada, para as séries A.1 e A.2, respectivamente.

Nas figuras 4.13 a 4.15, são vistos os valores de deslocamento, para as séries B.1 a B.3. Nas figuras 4.16 e 4.17, mostram-se a variação da curvatura e rigidez, respectivamente. 


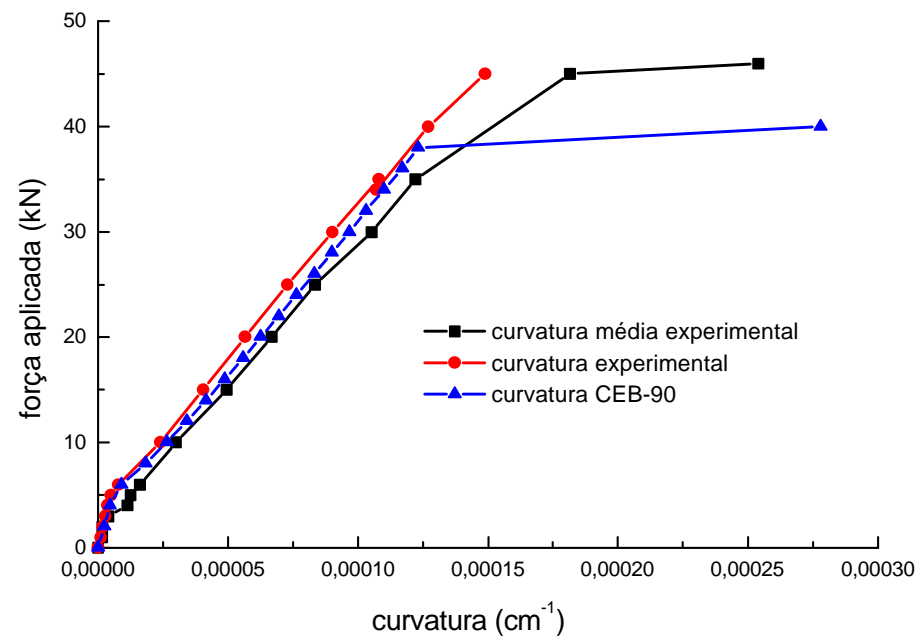

Fig.4.7 Força aplicada x curvatura - viga A.1

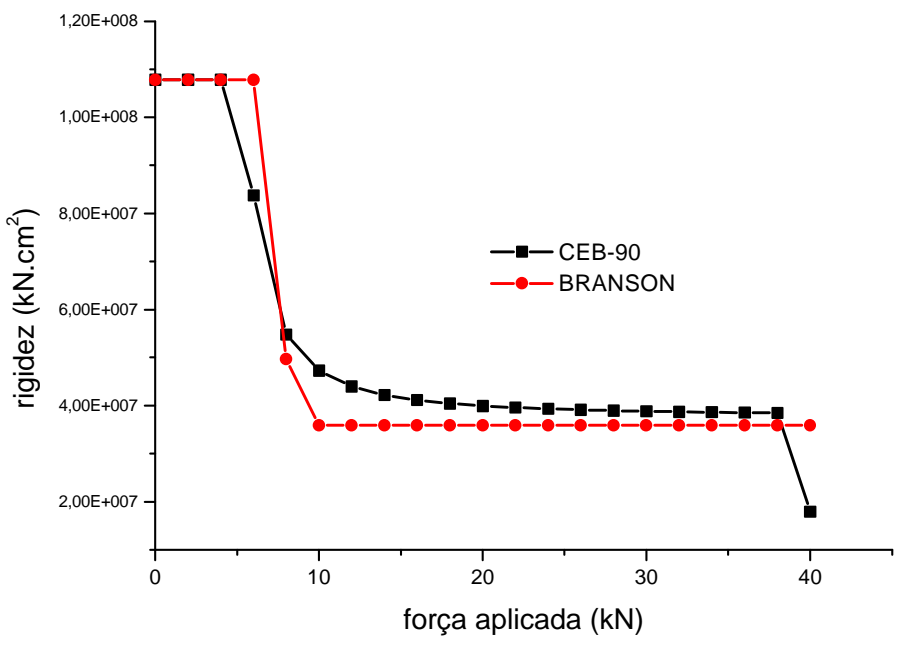

Fig.4.8 Rigidez x força aplicada - viga A.1

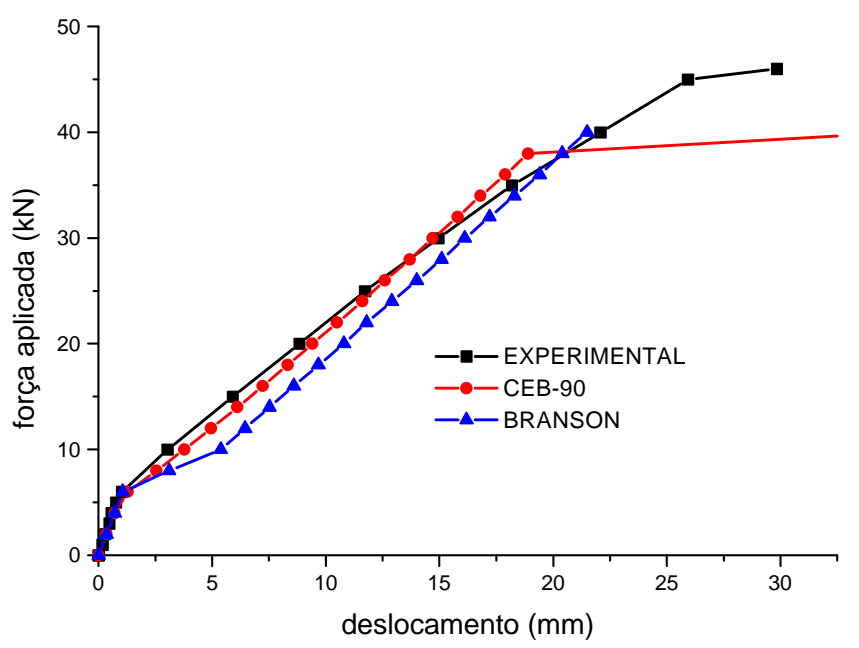

Fig.4.9 Força aplicada $x$ deslocamento - viga A.1 


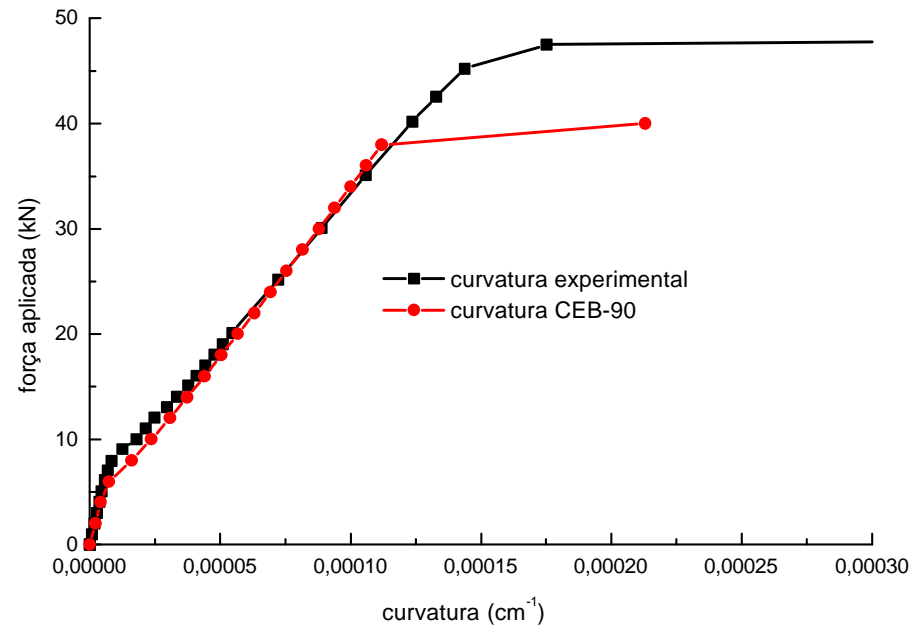

Fig.4.10 Força aplicada x curvatura - viga A.2

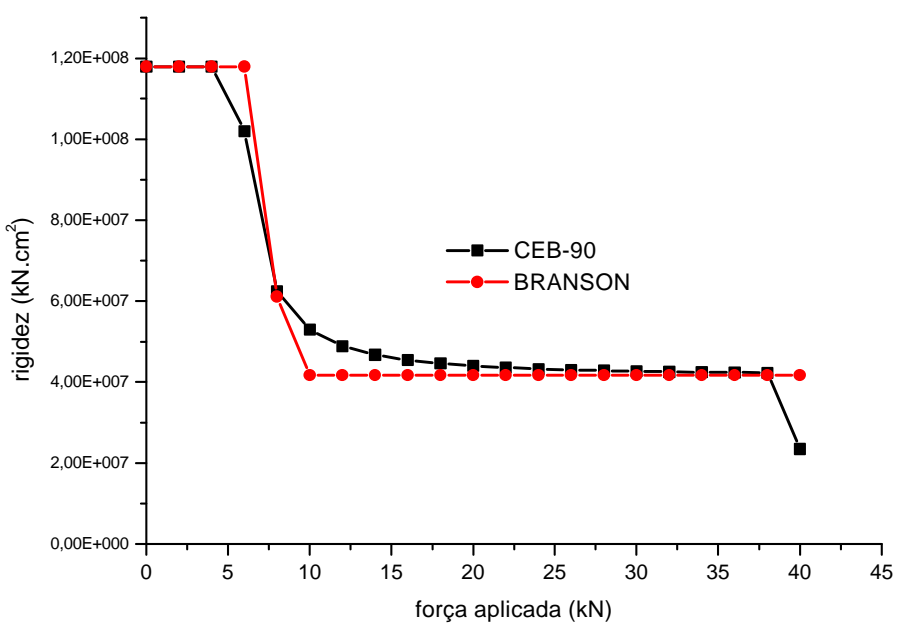

Fig.4.11 Rigidez x força aplicada - viga A.2

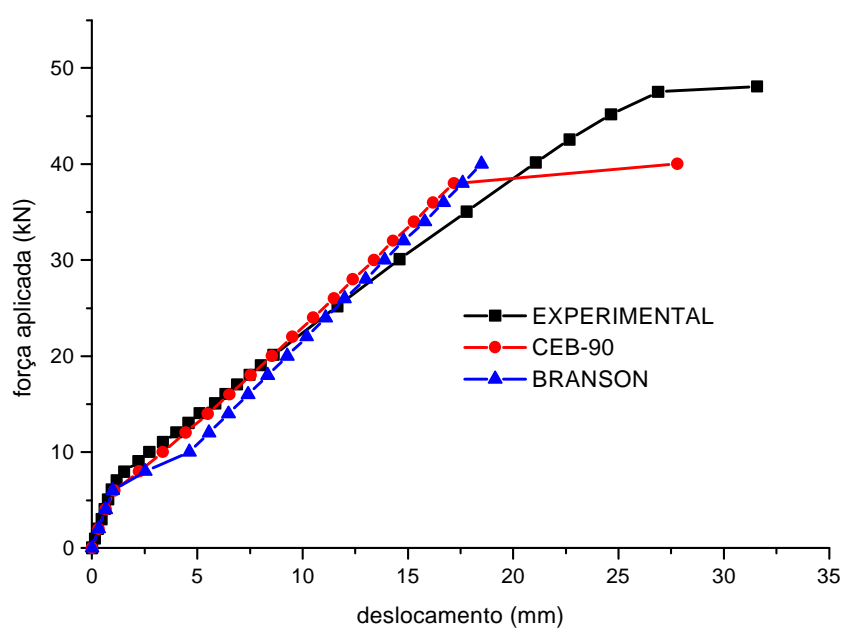

Fig.4.12 Força aplicada x deslocamento - viga A.2 


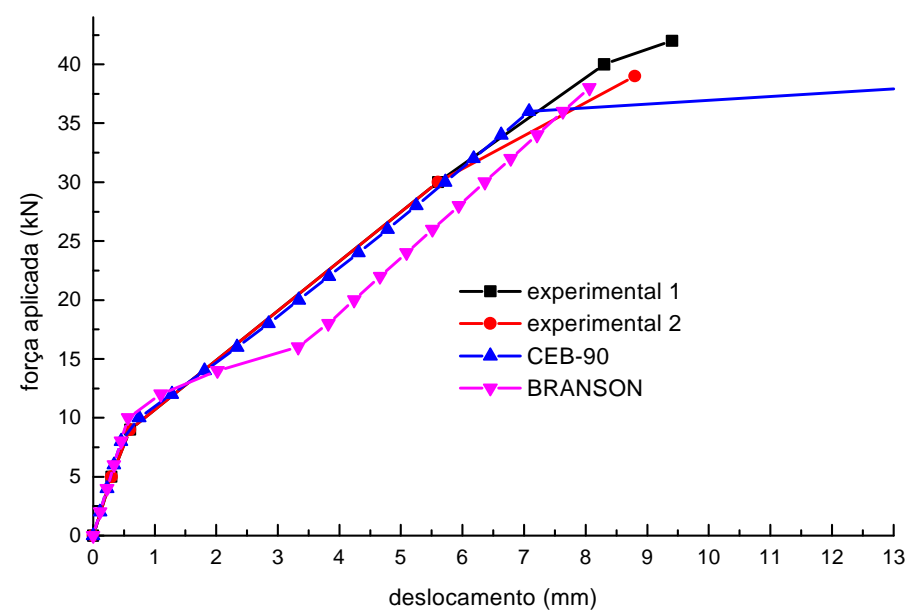

Fig.4.13 Força aplicada $\mathrm{x}$ deslocamento - viga B. 1 - taxa armadura $=0,67 \%$

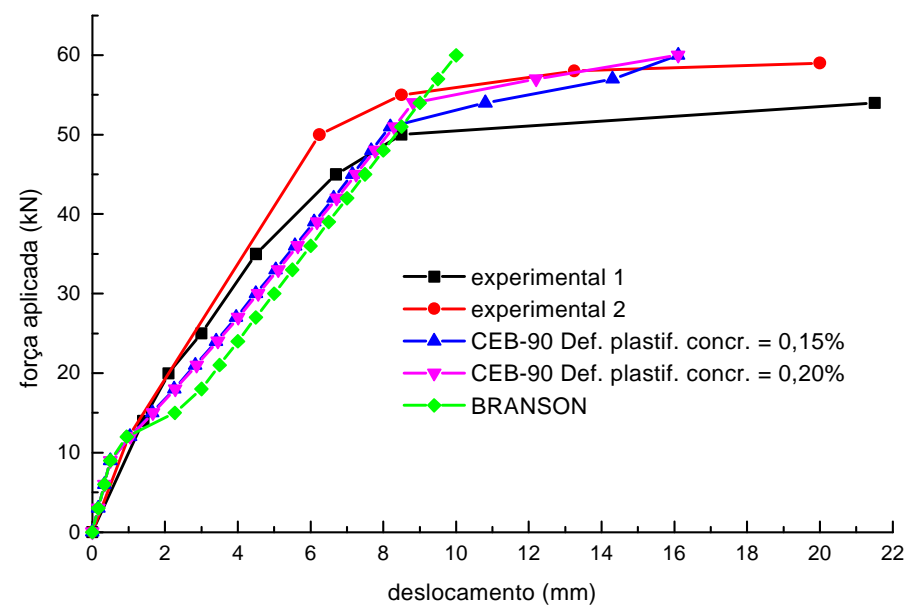

Fig.4.14 Força aplicada $\mathrm{x}$ deslocamento - viga B.2 - taxa armadura $=1,11 \%$

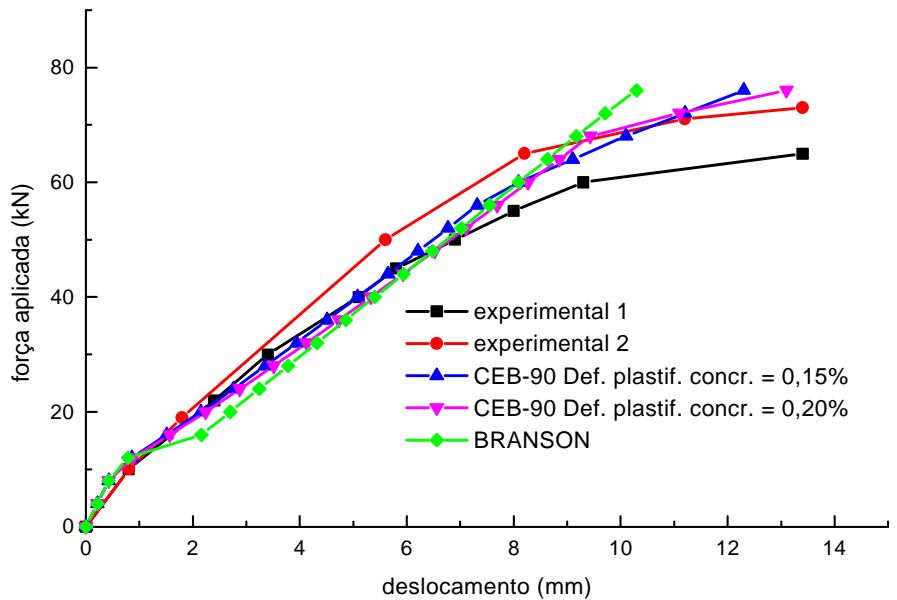

Fig.4.15 Força aplicada $x$ deslocamento - viga B. $3-$ taxa armadura $=1,56 \%$ 


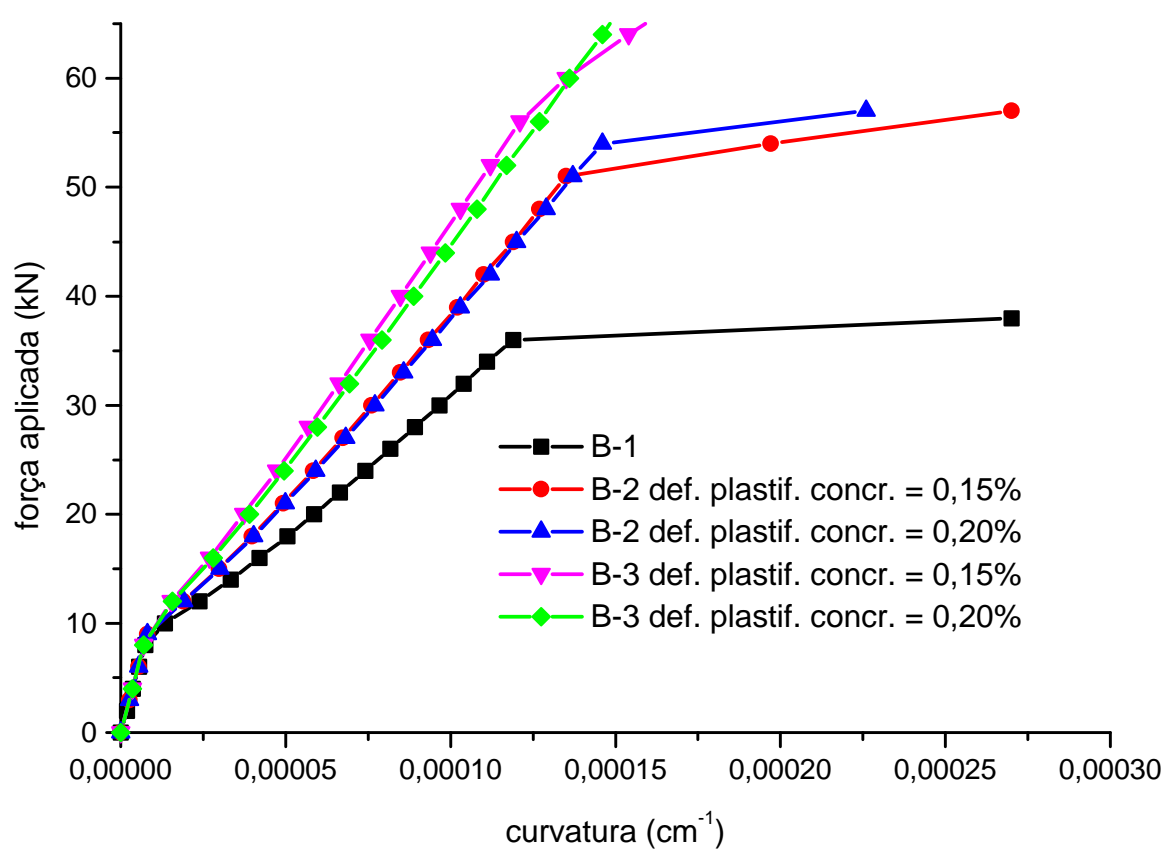

Fig.4.16 Força aplicada x curvatura - vigas B.1, B.2 e B.3

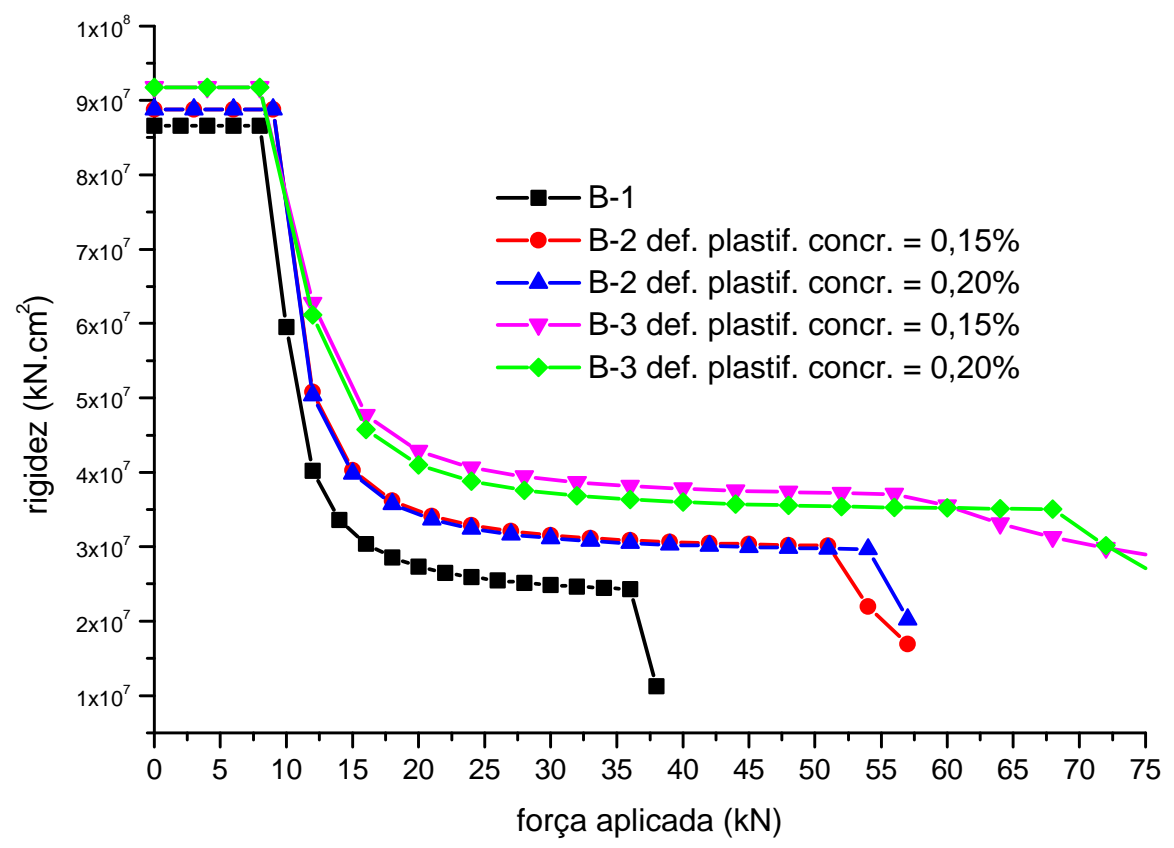

Fig.4.17 Diagrama rigidez x força aplicada - vigas B.1, B.2 e B.3 


\subsubsection{ANÁLISE DOS RESULTADOS}

De acordo com as figuras 4.7 e 4.10 , nota-se uma boa aproximação entre os valores da curvatura experimental com a curvatura teórica. A consideração da resistência média à tração por flexão igual a 1,2 e 1,5 vezes a resistência média à tração axial do concreto para as vigas com seção "I" e retangular, respectivamente foi satisfatória.

No que diz respeito aos valores de deslocamento das vigas, obtidos mediante as formulações do CEB-90 e BRANSON, tem-se uma boa aproximação com os valores experimentais. Sendo que os valores obtidos pelo CEB-90 são melhores, pois, representam melhor a curva experimental e também indicam o início da plastificação do concreto ou escoamento do aço.

Pode-se notar que os valores adotados da deformação do concreto, que caracterizam o início de plastificação, influem muito pouco no deslocamento, sendo que no decorrer do trabalho, será considerado o valor constante e igual a $1,5 \%$.

Nota-se no diagrama da figura 4.16 a relação força aplicada $x$ curvatura para as vigas retangulares. Para a viga B.3, onde se tem alta taxa de armadura, o trecho correspondente ao escoamento ou plastificação não fica bem definido, segundo o modelo teórico; caracterizando a ruptura frágil das peças superarmadas.

Um aspecto importante a ser ressaltado é que pela não realização do ensaio de resistência do aço utilizado, usou-se, nos cálculos, o valor de sua resistência característica, com isso subestima-se a resistência efetiva do aço nestas análises, ou seja:

$$
f_{y k}=500 M P a=f_{y m}
$$

Isto pode ser notado nos diagramas de força $x$ curvatura, onde se têm a discrepância de valores de início do escoamento do aço experimental e teórico. 


\subsection{PAINÉIS DE LAJES CONTÍNUAS}

Com a finalidade de analisar a continuidade entre dois painéis de laje, apresentam-se os resultados do estudo experimental realizado em lajes maciças de concreto, armadas com telas de aço soldada de diferentes áreas de seção transversal e comparações com valores teóricos.

Este ensaio realizado no Laboratório de Estruturas da Escola de Engenharia de São Carlos teve como principal objetivo analisar o problema da ancoragem de telas soldadas em lajes de concreto, atendendo à solicitação do IBTS - Instituto Brasileiro de Telas Soldadas.

\subsubsection{DESCRIÇÃO DOS MODELOS ANALISADOS}

Os modelos de laje analisados são constituídos de elementos de laje de dimensões 1,25 m x 3,12 m (figura 4.18), com dois vãos contínuos apoiados sobre três vigas numa direção e de bordas livres na direção perpendicular (comportamento estrutural unidirecional). As telas soldadas (figura 4.19) da armadura principal, classe CA-60, eram de três tipos:

a) tela superior

- EL138/92: fios de $\phi 4,2 \mathrm{~mm}$ - séries 1 a 4

- EL246/92: fios de $\phi 5,6 \mathrm{~mm}$ - séries 5 a 8

- EL503/131: fios de $\phi 8,0 \mathrm{~mm}$ - séries 9 a 12

b) tela inferior central

- L196: fios de $\phi 5,0 \mathrm{~mm}$ - séries 1 a 4

- L396: fios de $\phi 7,1 \mathrm{~mm}$ - séries 5 a 8

- L825: fios de $\phi 10,0 \mathrm{~mm}$ - séries 9 a 12

c) tela inferior borda

- ET138/69: fios de $\phi 4,2 \mathrm{~mm}$ - séries 1 a 12 


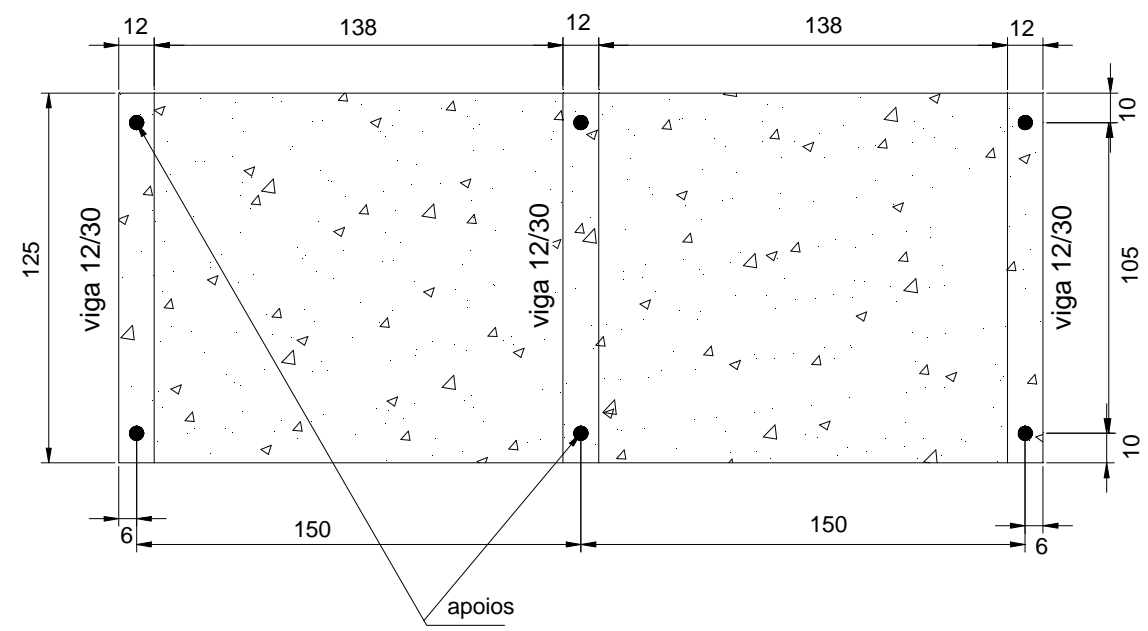

Fig.4.18 Planta de forma da placa - dimensões em cm
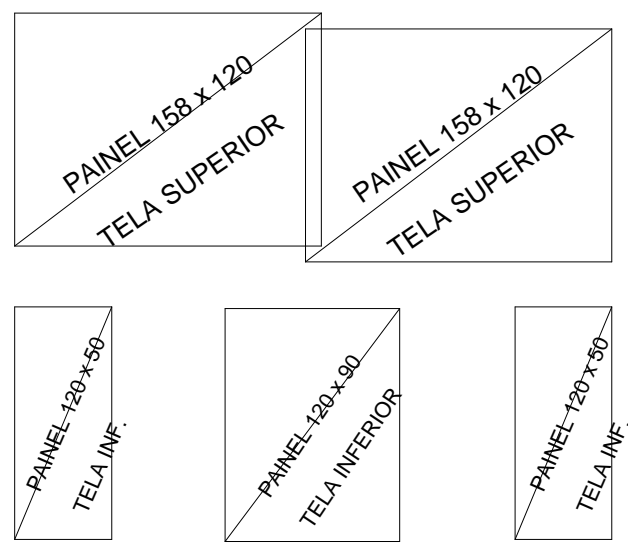

Fig.4.19 Armação dos painéis com telas soldadas

A espessura da laje das séries armadas com telas EL138/92 e EL246/92 era de $7 \mathrm{~cm}$, e a das séries armadas com a tela EL503/131 era de $8 \mathrm{~cm}$. Ao total foram ensaiadas 12 séries, sendo que as séries com numeração ímpar referem-se ao ensaio com carregamento centrado e as séries com numeração par foram ensaiadas com carregamento deslocado (figura 4.20). Neste trabalho, descrevem-se apenas as séries com carregamento centrado.

Neste trabalho analisam-se apenas os deslocamentos do vão central da laje, utilizando-se os valores obtidos pelos transdutores de deslocamentos. 


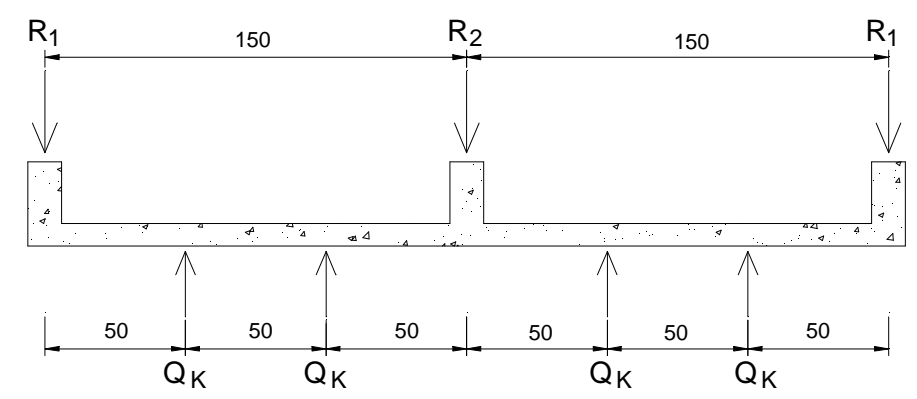

carregamento centrado - série 1,3,5,7,9 e 11

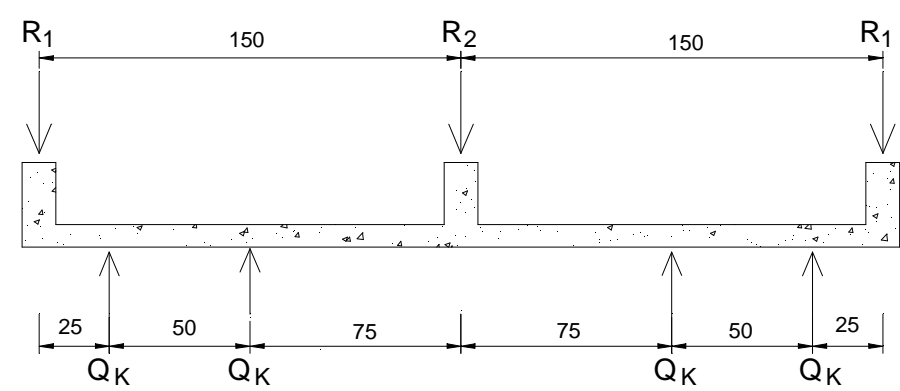

carregamento deslocado - série 2,4,6,8,10 e 12

$$
\begin{aligned}
\mathrm{Q}_{\mathrm{K}}= & \text { CARGA TOTAL DE ENSAIO (EM kN), APLICADA UNIFORMEMENTE NA } \\
& \text { LARGURA DO MODELO }(1,25 \mathrm{~m})(4 \mathrm{x}) \\
\mathrm{R}_{1}= & \text { REAÇÃO, EM kN, EM CADA APOIO EXTREMO }(4 \mathrm{x}) \\
\mathrm{R}_{2}= & \text { REAÇÃO, EM kN, EM CADA APOIO CENTRAL }(2 \mathrm{x})
\end{aligned}
$$

Fig.4.20 Esquema do ensaio - dimensões em cm

Determinou-se a resistência à compressão $\left(f_{c m}\right)$ e à tração do concreto $\left(f_{c t m}\right)$, aos 7 dias de idade, através de ensaios em corpos de prova à compressão axial e diametral, respectivamente.

A tensão de ruptura ou tensão última no aço $\left(f_{u}\right)$ foi obtida através de ensaios de tração uniaxial. Considera-se o valor da tensão de escoamento do aço igual a 0,85 $f_{u}$, e para o início de plastificação do concreto, com a deformação do mesmo igual a 1,5\% .

Os valores de módulo de elasticidade são calculados segundo 0 CEB-90 (1991).

Apresenta-se na tabela $\mathbf{4 . 3}$ a numeração das séries e os parâmetros envolvidos: 
Tabela 4.3 Numeração das séries e variáveis envolvidas.

\begin{tabular}{|c|c|c|c|c|c|c|c|c|}
\hline Série & $\begin{array}{c}\text { fios de } \\
\text { aço }\end{array}$ & $f_{c m, 7}$ & $f_{c t m, 7}$ & $E_{c}$ & $E_{c s}$ & $E_{s} / E_{c}$ & $f u(a c ̧ o)$ & $f y(a c ̧ o)$ \\
\hline 1 & liso & 1,95 & 0,19 & 2686 & 2283 & 7,8 & 72,4 & 61,5 \\
\hline 3 & corrugado & 2,11 & 0,21 & 2758 & 2344 & 7,6 & 72,4 & 61,5 \\
\hline 5 & liso & 2,2 & 0,23 & 2796 & 2377 & 7,5 & 83,3 & 70,8 \\
\hline 7 & corrugado & 2,86 & 0,26 & 3052 & 2594 & 6,9 & 83,3 & 70,8 \\
\hline 9 & liso & 1,94 & 0,21 & 2681 & 2279 & 7,8 & 77,7 & 66,1 \\
\hline 11 & corrugado & 1,68 & 0,17 & 2556 & 2173 & 8,2 & 77,7 & 66,1 \\
\hline
\end{tabular}

$f_{c m}, f_{c t m}, E_{c}, E_{c s}, f_{u}, f_{y}$ em $\mathrm{kN} / \mathrm{cm}^{2}$

Nas tabelas 4.4 e 4.5 apresentam-se as características geométricas e mecânicas dos elementos constituintes para cada série.

Tabela 4.4 Características geométricas e mecânicas dos elementos submetidos ao momento fletor positivo.

\begin{tabular}{|c|c|c|c|c|c|c|}
\hline Série & 1 & 3 & 5 & 7 & 9 & 11 \\
\hline$A s$ & 1,66 & 1,66 & 2,96 & 2,96 & 6,03 & 6,03 \\
\hline$A s 2$ & 0,00 & 0,00 & 0,00 & 0,00 & 0,00 & 0,00 \\
\hline$I_{I}$ & 3632 & 3630 & 3664 & 3656 & 5600 & 5615 \\
\hline$I_{I I}$ & 340 & 332 & 521 & 486 & 1325 & 1378 \\
\hline$M r$ & 298,2 & 329,4 & 366,2 & 412,5 & 452,6 & 368,0 \\
\hline Escoamento ou plastificação & ARMAD & ARMAD & ARMAD & ARMAD & CONCR & CONCR \\
\hline$M y$ & 551,24 & 553,41 & 1084,52 & 1099,40 & 1886,23 & 1729,17 \\
\hline $1 / r y$ & 0,00074 & 0,00073 & 0,00091 & 0,00088 & 0,00062 & 0,00058 \\
\hline Momento fletor último & DOM2A & DOM2A & DOM2B & DOM2B & DOM3 & DOM4 \\
\hline$M u$ & 660,8 & 662,0 & 1328,4 & 1393,9 & 2627,4 & 2509,4 \\
\hline $1 / r u$ & 0,00201 & 0,00199 & 0,00223 & 0,00215 & 0,00147 & 0,00130 \\
\hline RIGIDEZ (1) estádio II & 776192 & 778939 & 1238390 & 1259555 & 3018990 & 3071666 \\
\hline RIGIDEZ (2) estádio II & 747467 & 757346 & 1186790 & 1254782 & 3035580 & 2977637 \\
\hline DIFERENÇA \% & 3,70 & 2,77 & 4,17 & 0,38 & 0,55 & 3,16 \\
\hline
\end{tabular}


Tabela 4.5 Características geométricas e mecânicas dos elementos submetidos ao momento fletor negativo.

\begin{tabular}{|c|c|c|c|c|c|c|}
\hline Série & 1 & 3 & 5 & 7 & 9 & 11 \\
\hline$A s$ & 2,36 & 2,36 & 4,75 & 4,75 & 9,42 & 9,42 \\
\hline$A s 2$ & 1,66 & 1,66 & 2,96 & 2,96 & 6,03 & 6,03 \\
\hline$I_{I}$ & 3717 & 3713 & 3803 & 3782 & 6008 & 6048 \\
\hline$I_{I I} r$ & 461 & 451 & 740 & 692 & 1828 & 1900 \\
\hline$M r$ & 303,7 & 335,3 & 377,5 & 424,1 & 479,0 & 390,5 \\
\hline Escoamento ou plastificação & ARMAD & ARMAD & CONCR & CONCR & CONCR & CONCR \\
\hline$M y$ & 772,08 & 775,01 & 1446,84 & 1642,65 & 2424,37 & 2248,72 \\
\hline $1 / r y$ & 0,00077 & 0,00076 & 0,00079 & 0,00092 & 0,00058 & 0,00055 \\
\hline Momento fletor último & DOM2B & DOM2B & DOM3 & DOM2B & DOM4 & DOM4 \\
\hline$M u$ & 961,1 & 965,3 & 1956,7 & 1988,7 & 3866,4 & 3684,2 \\
\hline $1 / r u$ & 0,00210 & 0,00208 & 0,00193 & 0,00237 & 0,00132 & 0,00124 \\
\hline RIGIDEZ (1) estádio II & 1053290 & 1057657 & 1759946 & 1825643 & 4164903 & 4160969 \\
\hline RIGIDEZ (2) estádio II & 1000352 & 1014695 & 1789586 & 1798074 & 4211933 & 4089675 \\
\hline DIFERENÇA \% & 5,03 & 4,06 & 1,66 & 1,51 & 1,12 & 1,71 \\
\hline
\end{tabular}

RIGIDEZ (1) estádio II - Obtida pela homogeneização da seção

RIGIDEZ (2) estádio II - Obtida pela relação momento x curvatura

\subsubsection{MODELO ADOTADO E COMPARAÇÕES COM VALORES EXPERIMENTAIS}

As variáveis que se diferenciam em cada série são a área de aço e o tipo do fio utilizado (liso ou rugoso).

Nesta análise utiliza-se a relação momento x curvatura do CEB-90 e, para cada série, consideram-se dois valores para o parâmetro $\beta_{b}$ (produto de coeficientes que levam em conta a aderência das barras de aço e a repetitividade dos carregamentos). Para barras de má aderência $\beta_{b}$ é igual a 0,4 e para boa aderência igual a 0,8 .

O número de nós e elementos para esta análise são respectivamente 61 e 60 , sendo $5,0 \mathrm{~cm}$ o comprimento de cada elemento.

Apresenta-se nas figuras 4.21 a 4.26 , a relação força aplicada $x$ deslocamento no meio do vão dos painéis, para as séries submetidas ao carregamento centrado. 
Na figura 4.27 mostra-se, para a série $5 \operatorname{com} \beta_{b}$ igual a 0,4 , a variação do máximo momento fletor positivo e negativo em função da força aplicada e comparam-se com valores obtidos através de análise linear. Em todas as séries, os diagramas possuem a mesma característica, sendo por isto apresentados os valores de apenas uma série. Do mesmo modo, apresentase na figura $\mathbf{4 . 2 8}$ a variação da rigidez dos elementos submetidos ao máximo momento fletor positivo e negativo.

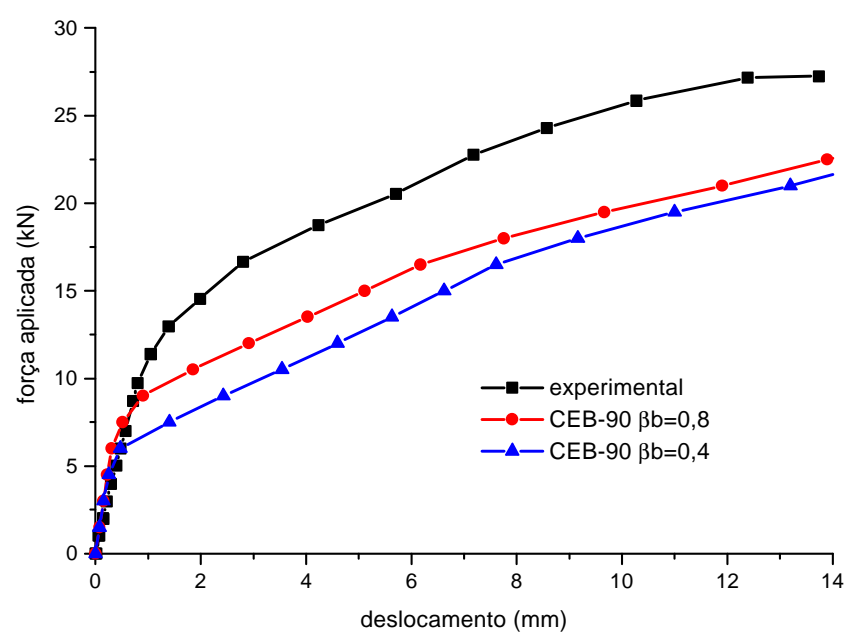

Fig.4.21 Força aplicada x deslocamento - série 1

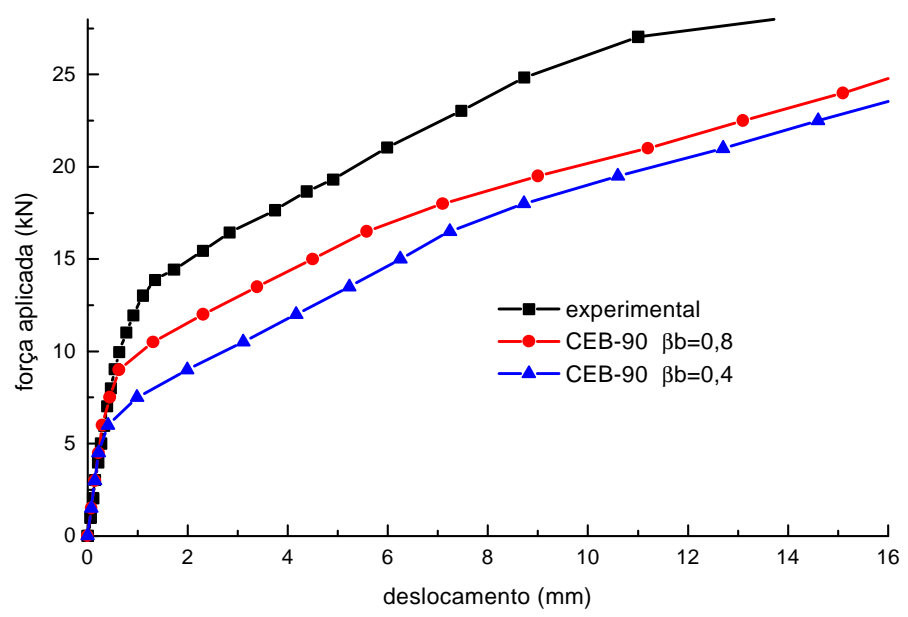

Fig.4.22 Força aplicada x deslocamento - série 3 


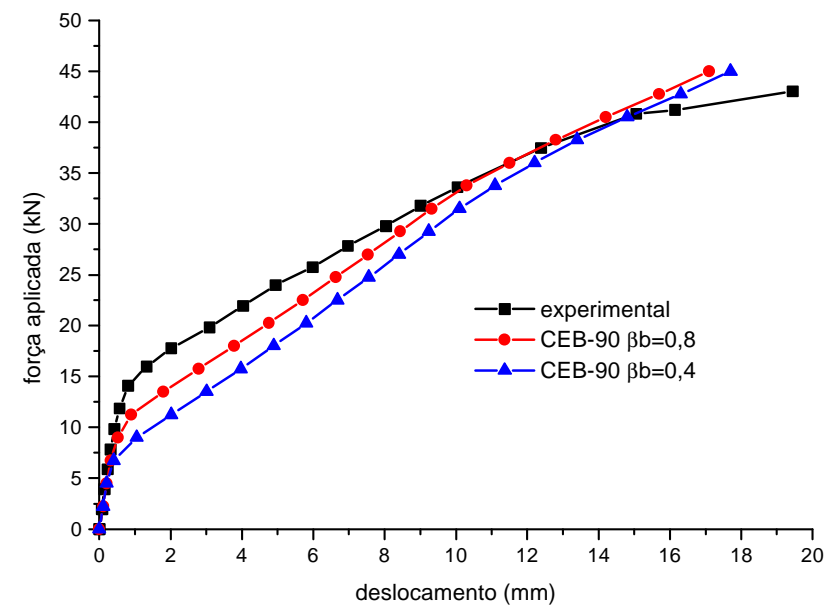

Fig.4.23 Força aplicada x deslocamento - série 5

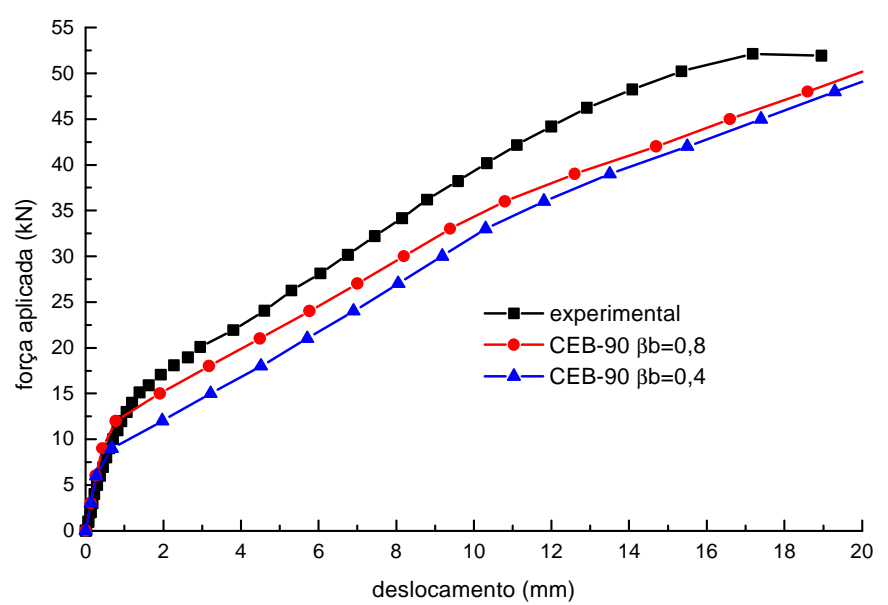

Fig.4.24 Força aplicada x deslocamento - série 7

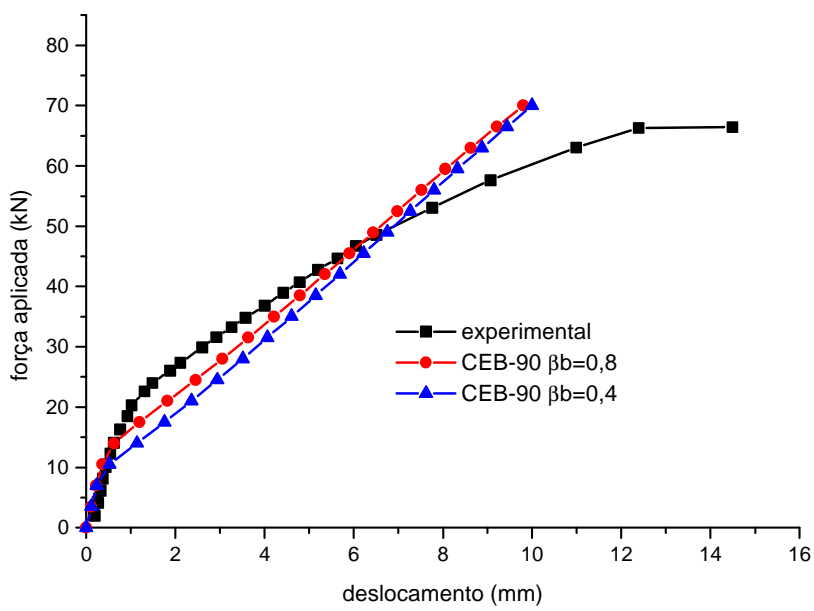

Fig.4.25 Força aplicada x deslocamento - série 9 


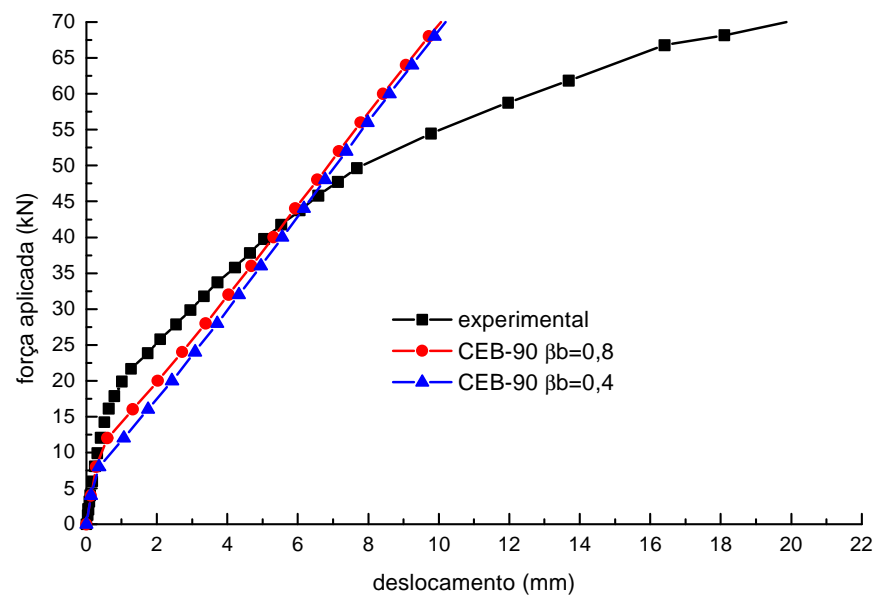

Fig.4.26 Força aplicada x deslocamento - série 11

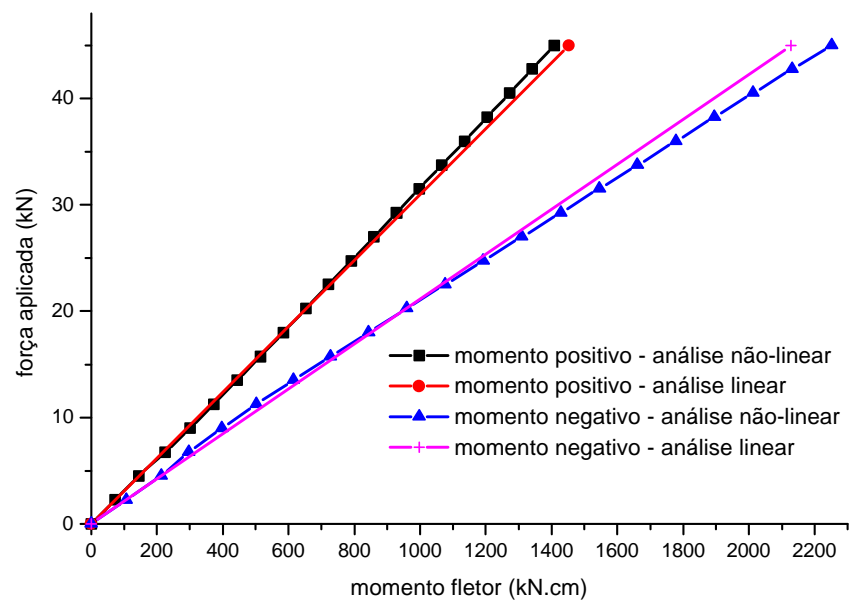

Fig.4.27 Força aplicada x momento fletor máximo - série 5 - $\beta_{\mathrm{b}}=0,4$

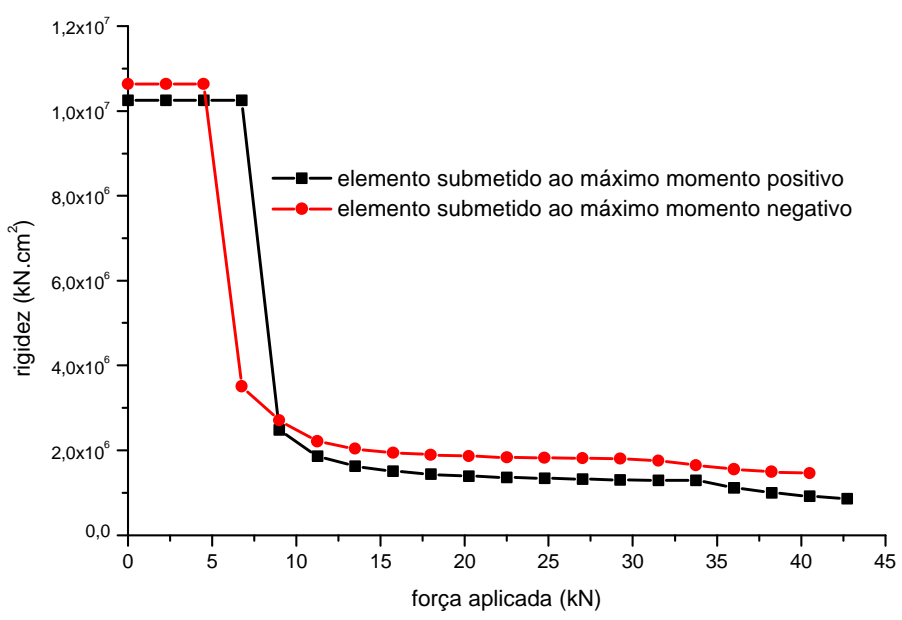

Fig.4.28 Rigidez x força aplicada - série $5-\beta_{b}=0,4$ 


\subsubsection{ANÁLISE DOS RESULTADOS}

Através dos diagramas de força aplicada $x$ deslocamento podemos notar que os valores teóricos de deslocamentos nas séries 1 e 3 foram maiores do que os valores experimentais. Isto ocorre devido à estimativa da resistência média à tração por flexão do concreto, que influi no valor de início de fissuração. A relação entre a resistência média à tração por flexão do concreto com a resistência média à tração, que neste caso foi considerada igual a 1,5 , deveria ser maior. Atribuindo isto pela pequena taxa de armadura, que influi na baixa retração do concreto. Considerando-se esta relação igual a 2, ocorre o deslocamento da curva teórica, obtendo-se uma grande aproximação com a curva experimental.

Nas séries 5 e 7, onde se tem uma maior taxa de armadura, há uma maior aproximação entre os valores teóricos e experimentais. Aumentandose a taxa de armadura (séries 9 e 11), tem-se uma boa resposta, mas notase pela elevada taxa de armadura que o modelo não consegue expressar o aumento de deslocamento devido ao escoamento ou plastificação.

Para todas as séries o valor de $\beta_{b}$ igual a 0,8 foi o mais satisfatório até mesmo para as séries em que se utilizou fios de aço liso.

$\mathrm{Na}$ figura 4.27 apresenta-se a variação do momento fletor positivo e negativo e nota-se que se aproxima de uma variação linear, ou seja, para este modelo adotado, não há grandes redistribuições de esforços ao longo do modelo em função da variação da rigidez calculada pelo modelo empregando a relação momento $x$ curvatura e carregamento incremental. Isto provavelmente acontece devido ao fato de que as variações de rigidez nos elementos ocorre quase que simultaneamente nos elementos submetidos ao máximo momento fletor positivo e negativo, como pode ser visto na figura 4.28 . 


\section{ANÁLISE EXPERIMENTAL DE UMA LAJE PRÉ-MOLDADA BIDIRECIONAL}

\subsection{CONSIDERAÇÕES INICIAIS}

Apresentam-se, neste capítulo, comparações entre os valores experimentais e teóricos de uma laje nervurada treliçada bidirecional.

$A$ análise teórica é realizada mediante $o$ uso das relações momento $x$ curvatura do CEB-90 (1991), do carregamento incremental e da analogia da grelha, sendo consideradas, portanto, a variação da rigidez à flexão e a rigidez à torção ao longo do carregamento da laje.

Os valores experimentais utilizados foram cedidos pela fábrica de lajes pré-moldada SALEMA, de São Bernardo do Campo. Este ensaio foi realizado pelo Departamento de Engenharia de Estruturas da Escola de Engenharia de São Carlos - USP, em uma prestação de serviços à fábrica SALEMA. 


\subsection{ESTRUTURA ANALISADA}

A laje bidirecional, executada nas dependências externas do Laboratório do Departamento de Estruturas, foi apoiada sobre alvenaria e com intereixo igual a $49 \mathrm{~cm}$. Em uma direção foram dispostas as vigotas treliçadas e entre elas enchimento de EPS, a nervura na outra direção se dá pelas cavidades formadas pelas abas do elemento de enchimento, conforme pode ser visto no esquema ilustrativo da figura 5.1.

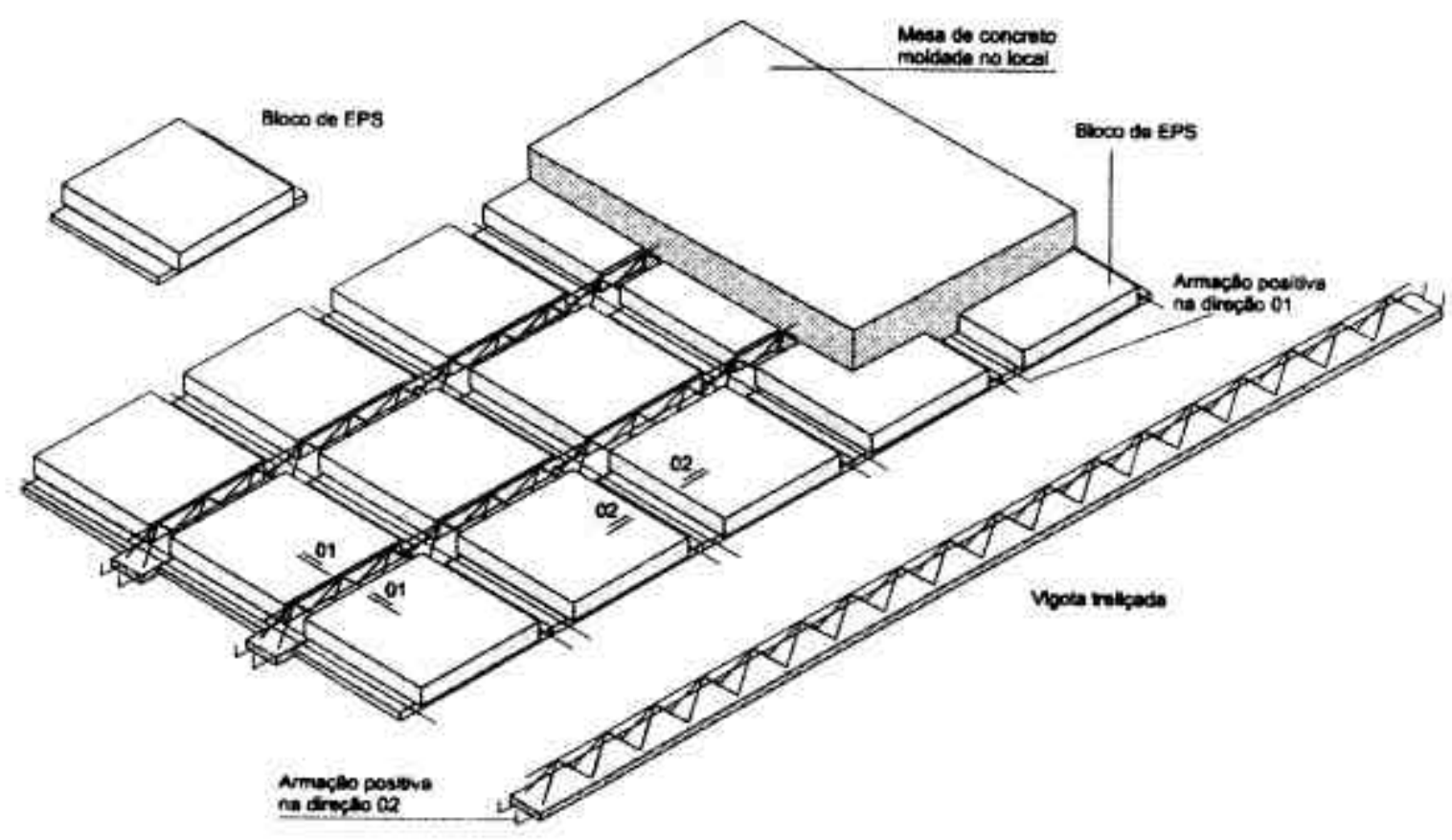

Fig.5.1 - Perspectiva da laje - FRANCA (1997)

Foram dispostas duas linhas de escora com aproximadamente 1 metro de distância entre elas. Como armadura construtiva, em cada direção foi colocada uma barra com diâmetro de 4,2 $\mathrm{mm}$ sobre cada EPS e também 2 barras (armação negativa) de diâmetro 4,2 mm sobre cada nervura, com comprimento de 1 metro, como pode ser visto na figura 5.2. Em função de sua geometria tem-se o peso próprio da laje igual a $1,60 \mathrm{kN} / \mathrm{m}^{2}$. 
O carregamento da estrutura foi feito com água. Por isso, foi montado um suporte de madeira (figura 5.3) e revestido com lona plástica para tornar possível o preenchimento com água (figura 5.4). Para o controle da altura d'água utilizou-se uma régua graduada de $5 \mathrm{em} 5 \mathrm{~cm}$, lembrando que $5 \mathrm{~cm}$ de altura correspondem a uma sobrecarga de $0,5 \mathrm{kN} / \mathrm{m}^{2}$.

Para a determinação do deslocamento do centro do vão, foram colocados 5 defletômetros na laje. Um foi posicionado no centro do vão e os outros 4 distribuídos em cada face para medir os deslocamentos próximos do apoio, como pode ser visto nas figuras 5.5 e 5.6 .

O ensaio consistiu na leitura dos defletômetros a cada $0,5 \mathrm{kN} / \mathrm{m}^{2}$ de carregamento. Em uma primeira etapa, a laje foi carregada até a sobrecarga de $3 \mathrm{kN} / \mathrm{m}^{2}$ (sobrecarga de projeto) e mantida durante 24 horas com este carregamento e depois foi feito o descarregamento. Em outra etapa a laje foi carregada até $6 \mathrm{kN} / \mathrm{m}^{2}$ com leituras durante o carregamento e descarregamento. Na figura 5.6 são reproduzidas as dimensões em planta da laje.

Observa-se na figura $\mathbf{5 . 7}$ as dimensões das seções transversais das nervuras. Na tabela 5.1, apresenta-se as características geométricas e mecânicas destas seções. A nervura longitudinal possui a armadura treliçada com fios de $4,2 \mathrm{~mm}$ no banzo inferior e a nervura transversal possui apenas um fio com diâmetro igual a $6,0 \mathrm{~mm}$.

Os valores da resistência média do concreto à compressão $f_{c m}$ e à tração $f_{c t m}$ são obtidos por ensaios de compressão axial e diametral em corpos de prova cilíndricos.

$$
\begin{array}{llrl}
f_{c m}=32 \mathrm{MPa} ; & f_{c t m}=3,1 \mathrm{MPa} & \text { (valores médios) } \\
E_{c}=31680 \mathrm{MPa} ; & E_{c s}=26930 \mathrm{MPa} & \text { (de acordo com o CEB90) }
\end{array}
$$




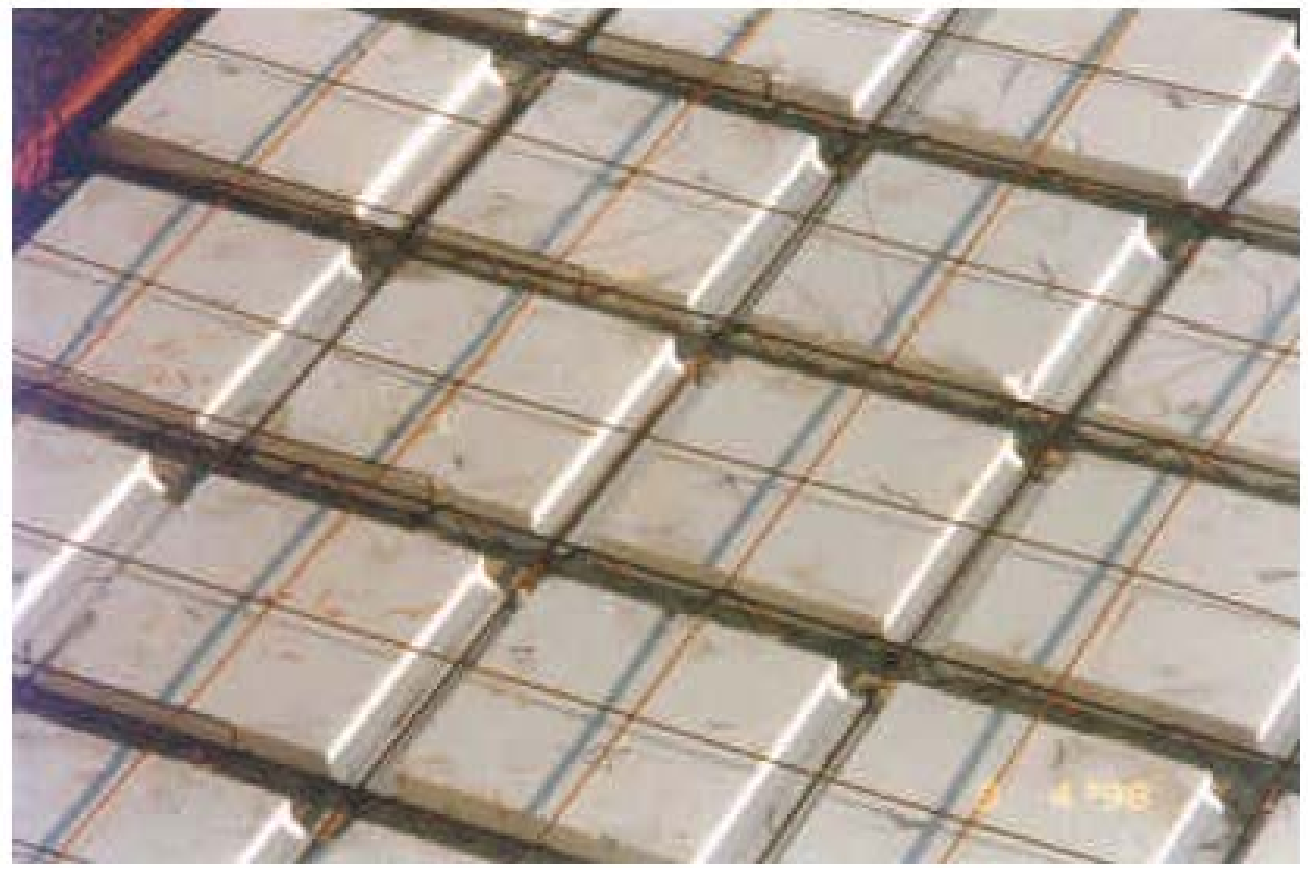

Fig.5.2 Vista da laje antes da concretagem

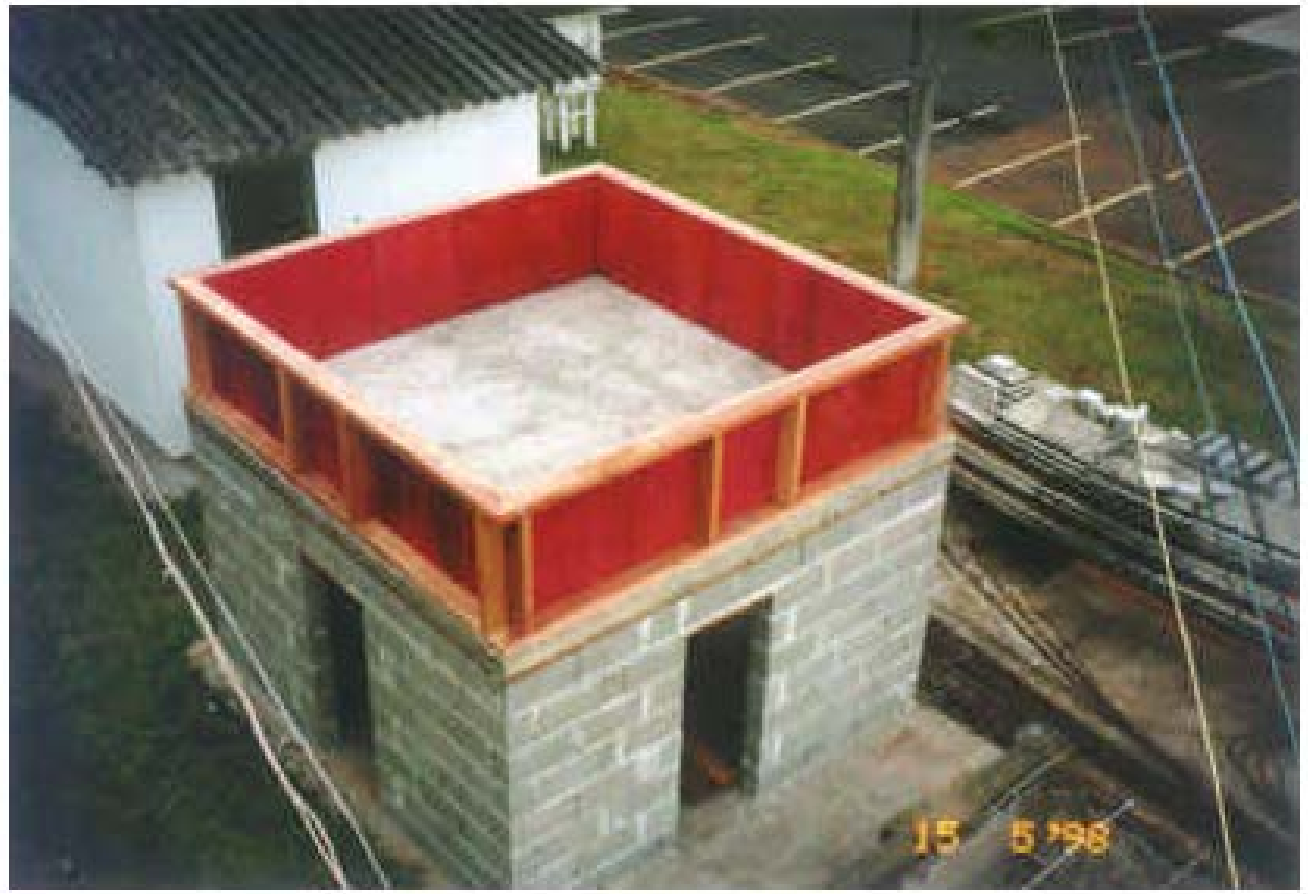

Fig.5.3 Vista geral do protótipo e do suporte de madeira utilizado para o carregamento com água 


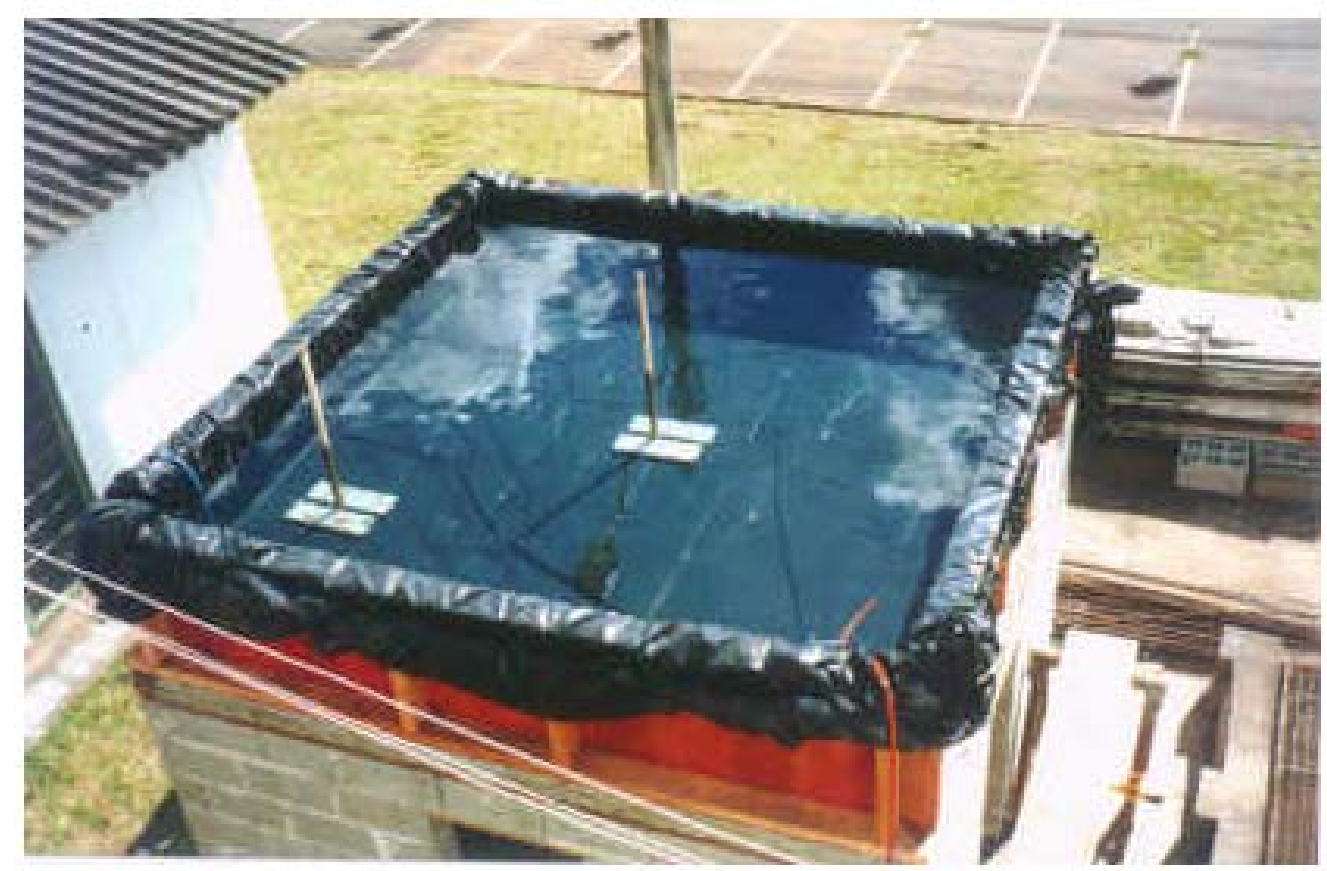

Fig.5.4 Laje com o carregamento máximo

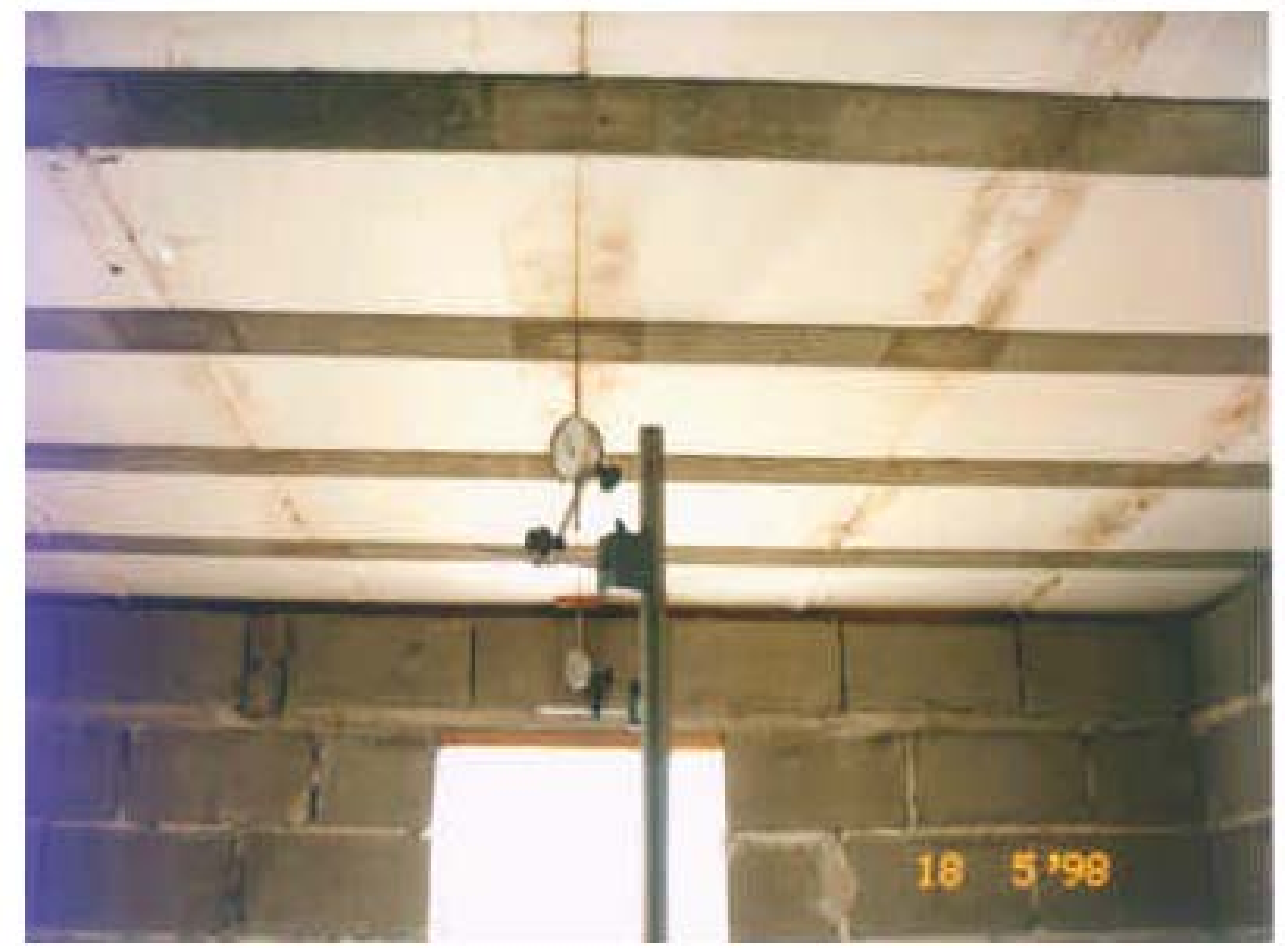

Fig.5.5 Posicionamento dos defletômetros 


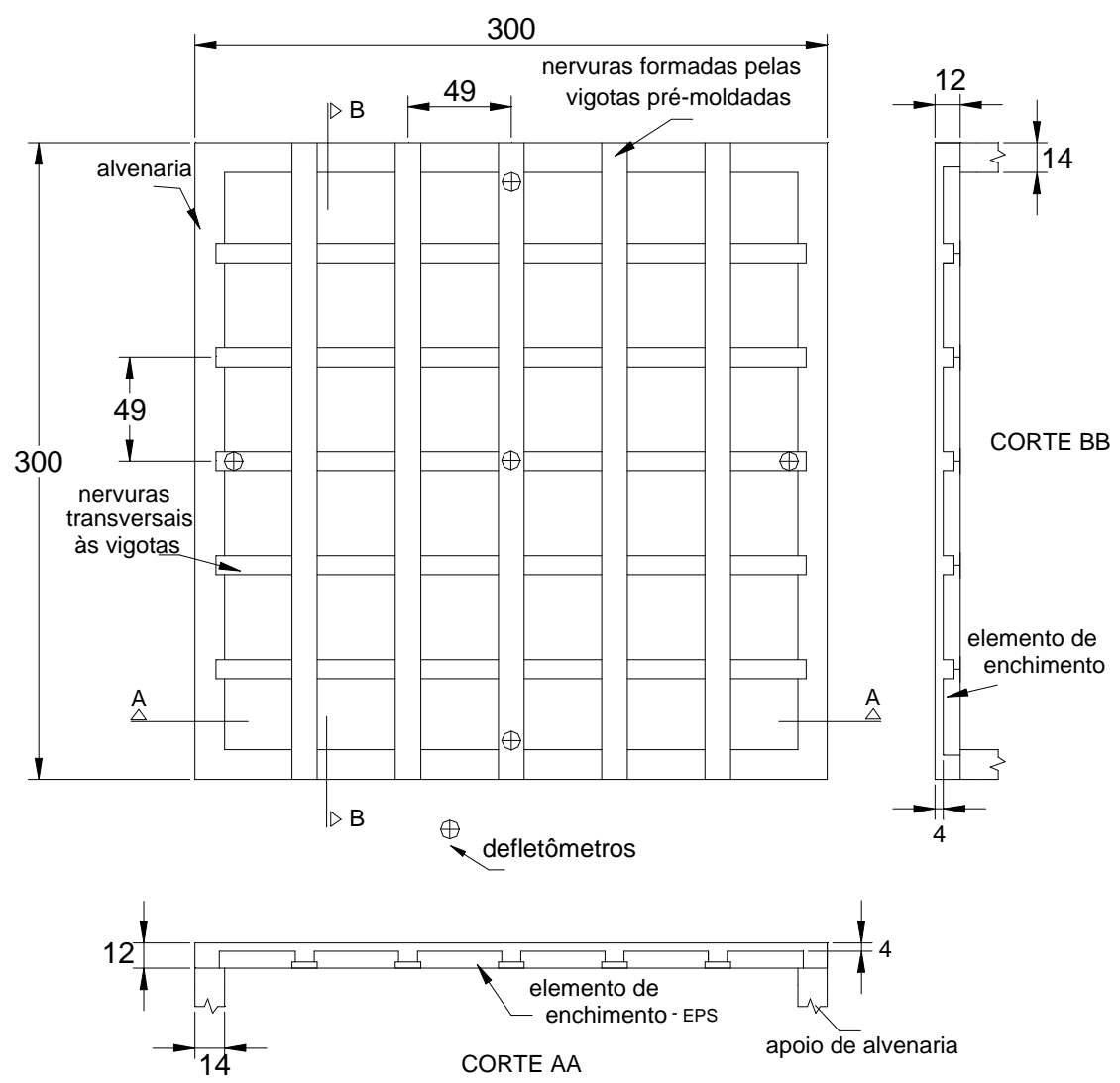

Fig.5.6 Localização das nervuras (dimensões em cm)

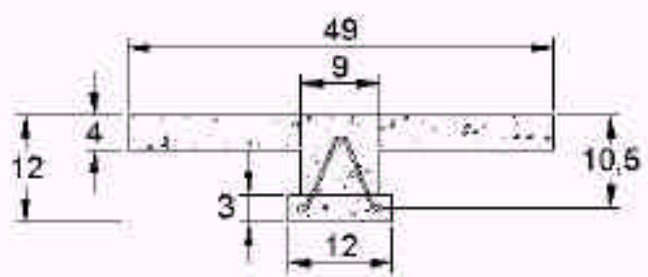

seçào transversal nervura formada pela vigota pré-moídada

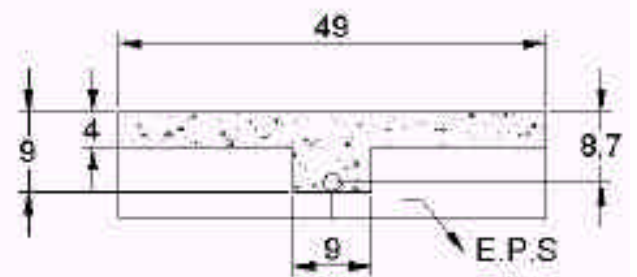

secảo transversal nervura transversal aे vigota premoldada

Fig.5.7 Seções transversais das nervuras (dimensões em cm)

Neste ensaio não foi determinada a tensão de ruptura ou tensão última no aço $\left(f_{u}\right)$ mediante ensaios de tração axial. Considera-se o valor característico $\left(f_{y k}\right)$ igual a $600 \mathrm{MPa}$.

Para o concreto, adota-se a deformação igual a 1,5\%o, referente ao início de plastificação. 
Tabela 5.1 Valores das características geométricas e mecânicas

\begin{tabular}{|c|c|c|}
\hline nervura & longitudinal & transversal \\
\hline$A s$ & 0,28 & 0,28 \\
\hline$I T$ & 2301 & 1667 \\
\hline$I o$ & 2961 & 1096 \\
\hline$I_{I}$ & 3031 & 1150 \\
\hline$I_{I I}$ & 182 & 124 \\
\hline$M r$ & 138,1 & 69,9 \\
\hline Escoamento ou plastificação & $\mathrm{ARMAD}$ & $\mathrm{ARMAD}$ \\
\hline$M y$ & 146,14 & 120,92 \\
\hline $1 / r y$ & 0,0003 & 0,00037 \\
\hline Momento fletor último & DOM2A & DOM2A \\
\hline$M u$ & 173,5 & 143,8 \\
\hline $1 / r u$ & 0,001 & 0,00121 \\
\hline RIGIDEZ (1) estádio II & 490451 & 333037 \\
\hline RIGIDEZ (2) estádio II & 484385 & 329464 \\
\hline DIFERENÇA \% & 1,25 & 1,08 \\
\hline
\end{tabular}

RIGIDEZ (1) estádio II - Obtida pela homogeneização da seção

RIGIDEZ (2) estádio II - Obtida pela relação momento x curvatura

\subsection{MODELOS ADOTADOS}

Os modelos adotados são grelhas, com espaçamentos entre as malhas iguais às distâncias entre as nervuras vistas na figura 5.5. Apresenta-se na figura $\mathbf{5 . 8}$ a grelha utilizada nos modelos.

Determinam-se os deslocamentos segundo O CEB-90, com carregamento incremental, e considera-se o valor para o parâmetro $\beta_{b}$ igual a 0,8 .

Pode ser visto na figura 5.6, as nervuras de borda, na qual a laje é apoiada. Para analisar a influência da rigidez à torção destas nervuras considera-se a seção da nervura de borda $(12 \mathrm{~cm} \times 14 \mathrm{~cm})$, com 0 valor do momento de inércia á torção $\left(I_{T}\right)$ calculado segundo LEONHARDT (1979), igual a $3854 \mathrm{~cm}^{4}$. Os deslocamentos das nervuras de extremidade são impedidos, pois estas foram moldadas sobre alvenaria. Conforme visto em 3.4, considera-se a variação da rigidez à torção nos elementos em função do momento fletor atuante. Como as nervuras de extremidade são 
apoiadas, fica-se sem parâmetros para variar a rigidez à torção em função apenas do momento fletor.

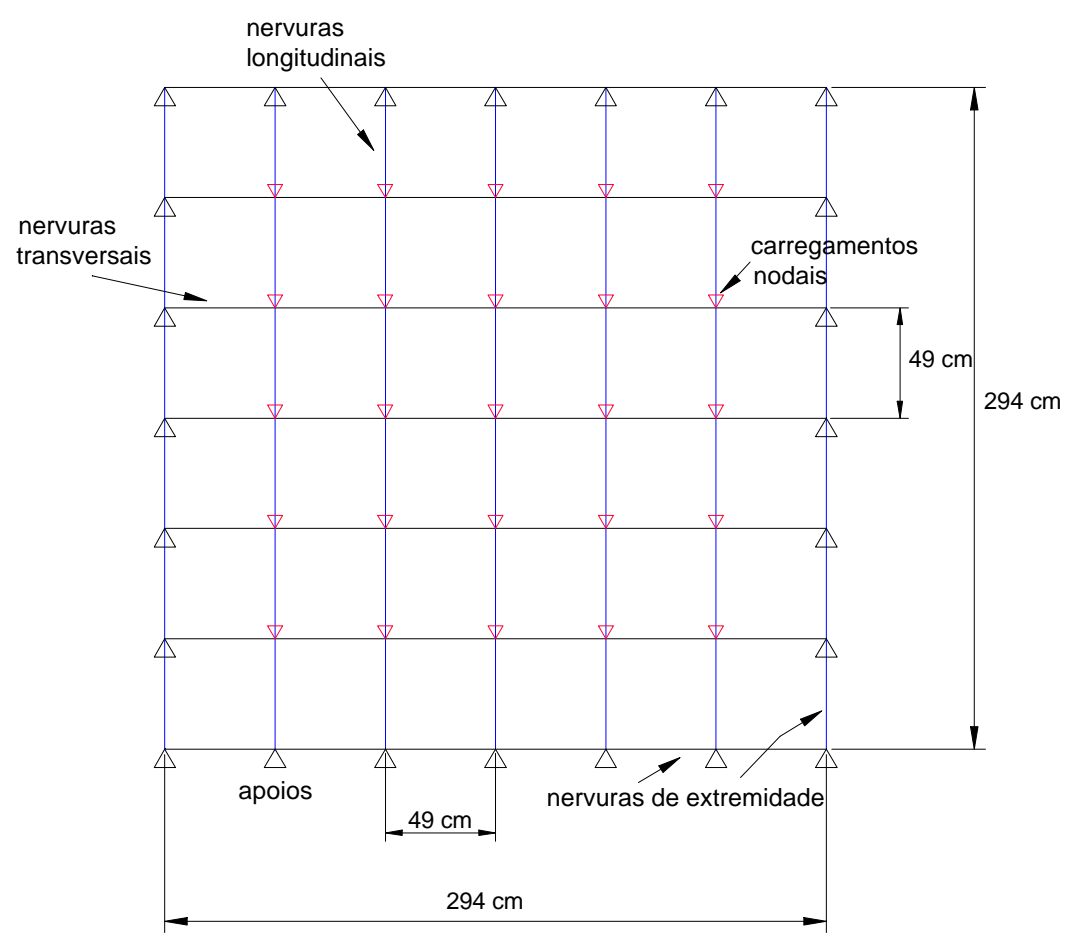

Fig.5.8 Malha da grelha

Adotam-se, portanto, três modelos ou casos teóricos para comparações com valores experimentais. Estes três modelos possuem variações de um para o outro apenas no parâmetro rigidez à torção.

Para o primeiro caso considera-se a rigidez à torção das nervuras da extremidade constante para o estádio I, os demais elementos (nervuras longitudinais e transversais) são valores variáveis, em função do momento fletor atuante. No segundo caso considera-se a rigidez à torção das nervuras da extremidade constante para o estádio II.

Para o terceiro caso considera-se a rigidez à torção de todos os elementos da laje constantes e iguais à rigidez do estádio II, variando-se apenas a rigidez à flexão em função do momento fletor. 
caso 1 - Rigidez à torção das vigas de extremidade constante estádio $\mathrm{I}=0,3 \cdot E_{c} \cdot I_{T}$

caso 2 - Rigidez à torção das vigas de extremidade constante estádio II $=0,05 . E_{c} . I_{T}$

caso 3 - Rigidez à torção constante a todos os elementos estádio II

Define-se o número de incrementos e o carregamento nodal na grelha em função do valor do peso próprio e sobrecarga:

$$
\begin{aligned}
& \text { peso próprio }=1,6 \mathrm{kN} / \mathrm{m}^{2} \\
& \text { peso próprio }+ \text { sobrecarga }\left(6,0 \mathrm{KN} / \mathrm{m}^{2}\right)=7,6 \mathrm{kN} / \mathrm{m}^{2}
\end{aligned}
$$

Adotando-se como referência o carregamento $7,6 \mathrm{kN} / \mathrm{m}^{2}$ e dividindo em 24 incrementos de carga tem-se $0,3167 \mathrm{kN} / \mathrm{m}^{2}$. Em termos de carregamento nodal tem-se $0,3167 \mathrm{kN} / \mathrm{m}^{2} \times 0,49 \mathrm{~m} \times 0,49 \mathrm{~m}=0,076032 \mathrm{kN}$.

Portanto: incremento 5 - peso próprio incremento 24 - peso próprio + sobrecarga $\left(6,0 \mathrm{kN} / \mathrm{m}^{2}\right)$

\subsection{COMPARAÇÃO DE VALORES TEÓRICOS COM EXPERIMENTAIS}

No ensaio não foi considerado o deslocamento devido ao peso próprio, e sim a partir da sobrecarga. De acordo com análises teóricas 0 deslocamento devido ao peso próprio é de aproximadamente $0,5 \mathrm{~mm}$. Conforme enunciado, a laje foi carregada até a sobrecarga de $3,0 \mathrm{kN} / \mathrm{m}^{2}$ e depois descarregada. No segundo ensaio carrega-se a laje até a sobrecarga de $6,0 \mathrm{kN} / \mathrm{m}^{2}$. A curva experimental até $3,0 \mathrm{kN} / \mathrm{m}^{2}$ tanto para o primeiro quanto para o segundo ensaio são idênticas. 
Apresentam-se, na figura $\mathbf{5 . 9}$ os valores teóricos e experimentais do deslocamento devido à atuação da sobrecarga. Os diagramas de momento fletor, na nervura que contém a vigota pré-moldada mais solicitada, para a sobrecarga igual a $6,0 \mathrm{kN} / \mathrm{m}^{2}$, segundo os três casos considerados, são vistos na figura $\mathbf{5 . 1 0}$.

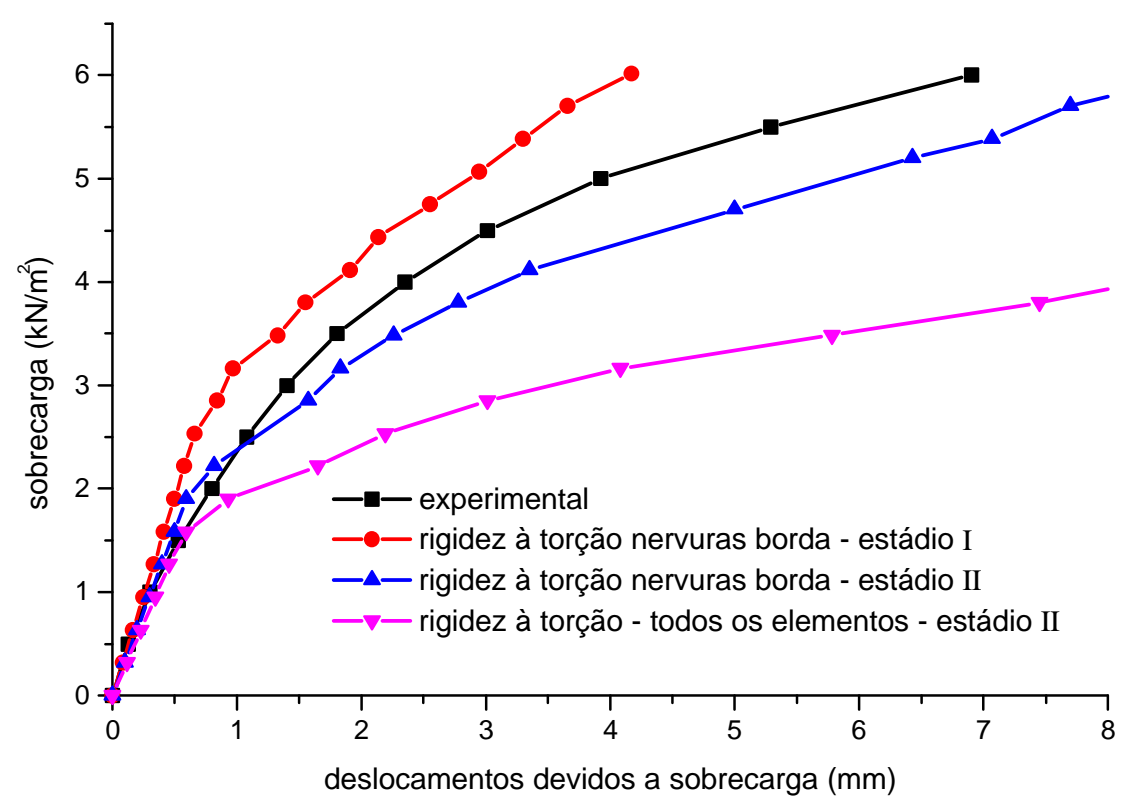

Fig.5.9 Diagrama de Sobrecarga $x$ deslocamento

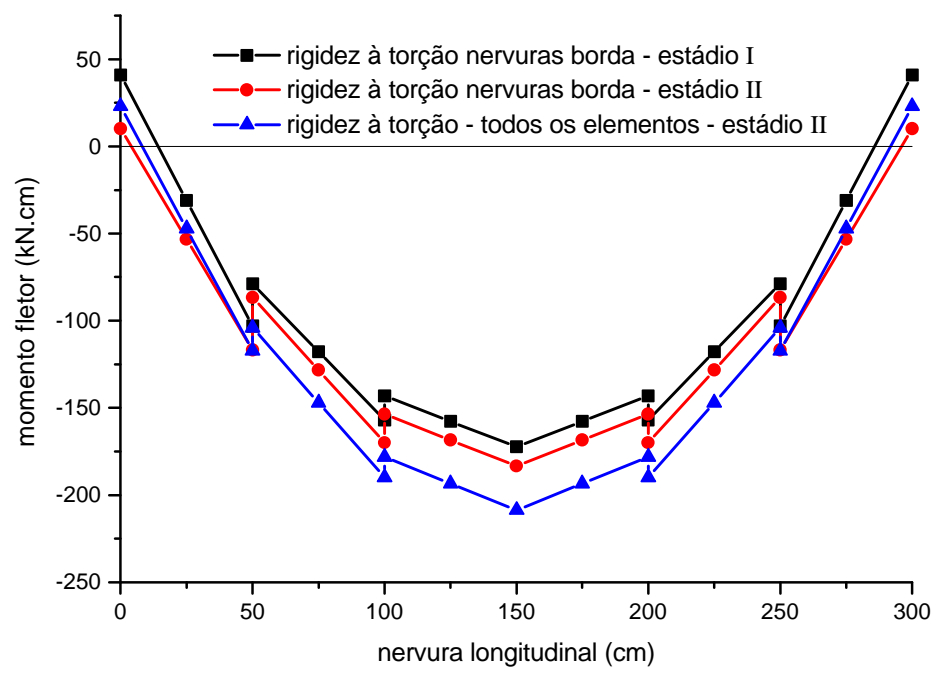

Fig.5.10 Diagrama de momento fletor para a sobrecarga de $6,0 \mathrm{kN} / \mathrm{m}^{2}$ 


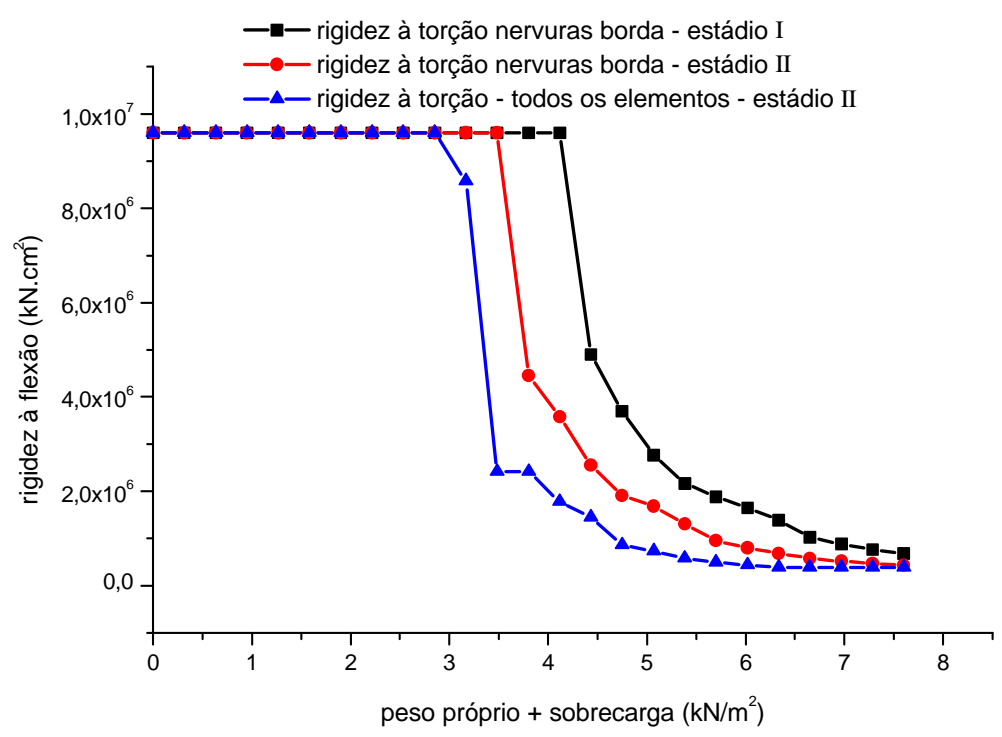

Fig.5.11 Diagrama rigidez à flexão $x$ carregamento da seção transversal da nervura longitudinal mais solicitada ao momento fletor

Como pode ser visto na figura 5.9, o valor experimental do deslocamento em serviço (sobrecarga de $3,0 \mathrm{kN} / \mathrm{m}^{2}$ ) é muito pequeno, sendo igual a $1,40 \mathrm{~mm}$.

O deslocamento ou flecha em lajes pode ser estimado segundo as tabelas BARES (1972). Os valores obtidos de deslocamento nestas tabelas são função da relação entre os vãos, da condição de apoio dos bordos da laje (apoiado, engastado ou livre), do valor do carregamento distribuído, da espessura da laje e do módulo de deformação longitudinal.

A espessura adotada para este cálculo é uma espessura equivalente, ou seja, calcula-se a espessura que fornece o mesmo valor de inércia à flexão das nervuras. Como se tem diferenças de inércia entre as nervuras, calculou-se a espessura para cada direção e determinou-se a média das espessuras, sendo igual a 7,6 cm . Segundo BARES (1972), obtém-se a flecha em serviço igual a $0,8 \mathrm{~mm}$. 
A seguir, apresenta-se na tabela 5.2, apenas para comparações, os valores de máximo momento fletor na nervura longitudinal, segundo os modelos de viga simplesmente apoiada, placa, grelha (análise linear e nãolinear). Na tabela $\mathbf{5 . 3}$ apresentam-se os deslocamentos para a sobrecarga igual a $3,0 \mathrm{kN} / \mathrm{m}^{2}$.

Tabela 5.2 Valores de máximo momento fletor - peso próprio + sobrecarga de $6,0 \mathrm{kN} / \mathrm{m}^{2}$

\begin{tabular}{|c|c|c|}
\hline $\begin{array}{c}\text { modelo } \\
\text { considerado }\end{array}$ & $\begin{array}{c}\text { máximo momento } \\
\text { nervura longitudinal }\end{array}$ & $\begin{array}{c}\text { fletor (kN.cm) } \\
\text { nervura transversal }\end{array}$ \\
\hline $\begin{array}{c}\text { viga simplesmente apoiada } \\
\text { análise não-linear }\end{array}$ & 402 & $*$ \\
\hline placa (BARES) & 278 & 83 \\
\hline $\begin{array}{c}\text { grelha - análise linear } \\
\text { rigidez à torção - estádio I }\end{array}$ & 233 & 110 \\
\hline $\begin{array}{c}\text { grelha - análise linear } \\
\text { rigidez à torção - estádio II }\end{array}$ & 316 & 87 \\
\hline $\begin{array}{c}\text { grelha - análise não-linear } \\
\text { rigidez à torção das vigas } \\
\text { de extremidade no estádio I }\end{array}$ & 170 & 100 \\
\hline $\begin{array}{c}\text { grelha - análise não-linear } \\
\text { rigidez à torção das vigas } \\
\text { de extremidade no estádio II }\end{array}$ & 183 & 125 \\
\hline $\begin{array}{c}\text { grelha - análise não-linear } \\
\text { rigidez à torção de todos os } \\
\text { elementos no estádio II }\end{array}$ & 206 & \\
\hline
\end{tabular}

Tabela 5.3 Deslocamento - sobrecarga de 3,0 kN/m²

\begin{tabular}{|c|c|}
\hline $\begin{array}{c}\text { modelo } \\
\text { considerado }\end{array}$ & $\begin{array}{c}\text { deslocamento } \\
\text { (mm) }\end{array}$ \\
\hline experimental & 1,4 \\
\hline $\begin{array}{c}\text { viga simplesmente apoiada } \\
\text { análise não-linear }\end{array}$ & 1,5 \\
\hline placa (BARES) & 0,8 \\
\hline $\begin{array}{c}\text { grelha - análise linear } \\
\text { rigidez à torção - estádio I }\end{array}$ & 0,8 \\
\hline $\begin{array}{c}\text { grelha - análise linear } \\
\text { rigidez à torção - estádio II }\end{array}$ & 1,1 \\
\hline $\begin{array}{c}\text { grelha - análise não-linear } \\
\text { rigidez à torção das vigas } \\
\text { de extremidade no estádio I }\end{array}$ & 0,9 \\
\hline $\begin{array}{c}\text { grelha - análise não-linear } \\
\text { rigidez à torção das vigas } \\
\text { de extremidade no estádio II }\end{array}$ & 1,7 \\
\hline $\begin{array}{c}\text { grelha - análise não-linear } \\
\text { rigidez à torção de todos os } \\
\text { elementos no estádio II }\end{array}$ & 3,6 \\
\hline
\end{tabular}




\subsection{ANÁLISE DOS RESULTADOS}

Como principal objetivo desta análise teórico-experimental, é a verificação dos valores de rigidez à torção, sugeridos pelo CEB-90.

Neste estudo teórico-experimental, verifica-se a grande influência da rigidez à torção no que diz respeito aos valores de deslocamentos. Com a redução da rigidez à torção, utilizando-se apenas a rigidez do estádio II, para todos os elementos, a diferença de deslocamento entre o valor teórico e experimental para a situação de serviço $\left(3,0 \mathrm{kN} / \mathrm{m}^{2}\right)$ é grande, cerca de $170 \%$.

No que diz respeito à consideração da rigidez das nervuras de extremidade, os resultados obtidos foram os esperados, pois a curva experimental é a curva intermediária entre as curvas teóricas calculadas com a rigidez à torção das nervuras da extremidade constantes para o estádio I e II. A princípio, pela falta de um estudo mais detalhado, pode-se considerar o valor constante da rigidez à torção do estádio II. Para a análise mais profunda da influência das nervuras ou vigas de extremidade, devem ser realizados ensaios experimentais das lajes apoiadas apenas em apoios simples e comparações com outros ensaios da mesma laje solidarizada em vigas de extremidade. Muitas variáveis são envolvidas neste caso: altura da laje, dimensões da viga de extremidade, altura da camada do concreto de capeamento, armadura "negativa" da laje na ligação laje-viga e outros.

A consideração da rigidez à torção nos elementos, como é de se esperar, contribui na modificação dos valores de momento fletor nas nervuras, como pode ser visto nos gráficos da figura $\mathbf{5 . 1 0}$.

De acordo com a tabela $\mathbf{5 . 2}$ observa-se a diferença entre os valores de momento fletor, segundo os modelos adotados. Sendo que há uma diferença expressiva, entre o valor do máximo momento fletor na nervura longitudinal obtido mediante a análise linear e não-linear, admitindo-se que ocorra a redistribuição dos esforços. 
Nota-se que os deslocamentos teóricos e experimentais são menores do que o limite imposto na NBR-6118 (1982) igual a 1/300 do vão da laje, pois se trata de um vão relativamente pequeno e atuação de apenas cargas distribuídas. Para vãos maiores e com carregamentos concentrados ou em linha (paredes), este limite pode ser atingido, causando fissurações nos elementos (laje, alvenaria) e também problemas de ordem estética.

Com a não consideração da rigidez à torção, desperdiça-se a capacidade resistente da laje, seja referente às verificações de deslocamentos ou esforços solicitantes.

O estudo mais detalhado destas lajes seja unidirecional ou bidirecional, através de análises teóricas e experimentais, permitirá avaliar o valor e a influência da rigidez à torção, no que diz respeito à distribuição de esforços e cálculo de deslocamentos. 


\section{SIMULAÇÕES NUMÉRICAS DE SITUACÕES REPRESENTATIVAS}

6

\subsection{CONSIDERAÇÕES INICIAIS}

Neste capítulo apresentam-se simulações numéricas de lajes nervuradas formadas por vigotas pré-moldadas, com alturas iguais a 12 e 20 $\mathrm{cm}$.

A análise consiste na determinação dos valores de momento fletor, reação de apoio e deslocamentos, sendo considerados os modelos de viga e de grelha.

No modelo de viga foram analisadas as vigas isoladas e vigas contínuas. No modelo de grelha foram analisadas as grelhas isoladas e as grelhas contínuas.

Analisa-se também a influência das vigas de sustentação das lajes (rigidez à torção e a deformabilidade).

Em termos de arranjos estruturais, analisa-se a influência da altura da laje, do formato em planta e do tipo (unidirecional ou bidirecional). 


\subsection{MODELOS E ARRANJOS ESTRUTURAIS}

Apresentam-se na tabela seguir, os modelos e arranjos estruturais analisados neste capítulo.

Tabela 6.1 Modelos e arranjos estruturais

\begin{tabular}{|c|c|c|c|}
\hline \multicolumn{2}{|l|}{ modelos } & arranjos estruturais & formato em planta \\
\hline \multirow{2}{*}{\multicolumn{2}{|c|}{$\begin{array}{l}\text { modelo } \\
\text { de viga }\end{array}$}} & viga simplesmente apoiada (viga contínua) & * \\
\hline & & viga contínua & * \\
\hline \multirow{14}{*}{$\begin{array}{c}\text { modelo } \\
\text { de } \\
\text { grelha }\end{array}$} & \multirow{8}{*}{$\begin{array}{l}\text { grelha } \\
\text { isolada }\end{array}$} & \multirow[t]{2}{*}{ laje unidirecional } & $6,0 \mathrm{~m} \times 6,0 \mathrm{~m}$ \\
\hline & & & $12,0 \mathrm{~m} \times 6,0 \mathrm{~m}$ \\
\hline & & \multirow[t]{2}{*}{ laje unidirecional c/ nerv. transversais } & $6,0 \mathrm{~m} \times 6,0 \mathrm{~m}$ \\
\hline & & & $12,0 \mathrm{~m} \times 6,0 \mathrm{~m}$ \\
\hline & & \multirow[t]{2}{*}{ laje bidirecional } & $6,0 \mathrm{~m} \times 6,0 \mathrm{~m}$ \\
\hline & & & $12,0 \mathrm{~m} \times 6,0 \mathrm{~m}$ \\
\hline & & $\begin{array}{l}\text { laje unidirecional considerando a rigidez } \\
\text { à torção das vigas de extremidade }\end{array}$ & $6,0 \mathrm{~m} \times 6,0 \mathrm{~m}$ \\
\hline & & $\begin{array}{l}\text { laje bidirecional considerando a rigidez } \\
\text { à torção das vigas de extremidade }\end{array}$ & $6,0 \mathrm{~m} \times 6,0 \mathrm{~m}$ \\
\hline & \multirow{6}{*}{$\begin{array}{l}\text { grelha } \\
\text { contínua }\end{array}$} & \multirow{2}{*}{$\begin{array}{l}\text { laje unidirecional continua com o } \\
\text { deslocamento da viga de apoio livre }\end{array}$} & $12,0 \mathrm{~m} \times 6,0 \mathrm{~m}$ \\
\hline & & & \\
\hline & & \multirow{2}{*}{$\begin{array}{c}\text { laje unidirecional continua com o } \\
\text { deslocamento da viga de apoio impedido }\end{array}$} & $12,0 \mathrm{~m} \times 6,0 \mathrm{~m}$ \\
\hline & & & \\
\hline & & \multirow{2}{*}{$\begin{array}{l}\text { laje unidirecional contínua com as nervuras } \\
\text { dispostas em direcões ortogonais }\end{array}$} & $12,0 \mathrm{~m} \times 6,0 \mathrm{~m}$ \\
\hline & & & \\
\hline
\end{tabular}

Obs: Nos arranjos estruturais apresentados, tem-se a altura da laje igual a 12 e $20 \mathrm{~cm}$.

Adotam-se, portanto, duas alturas de laje pré-moldada, 12 e $20 \mathrm{~cm}$, com intereixo igual a $50 \mathrm{~cm}$ e espessura da capa de concreto igual a $4 \mathrm{~cm}$. Considera-se o E.P.S. (isopor) como elemento de enchimento. Apresenta-se na figura 6.1 a seção transversal das nervuras longitudinais (nervura formada pela vigota pré-moldada e o concreto moldado no local) e as características geométricas das seções apresentadas. 

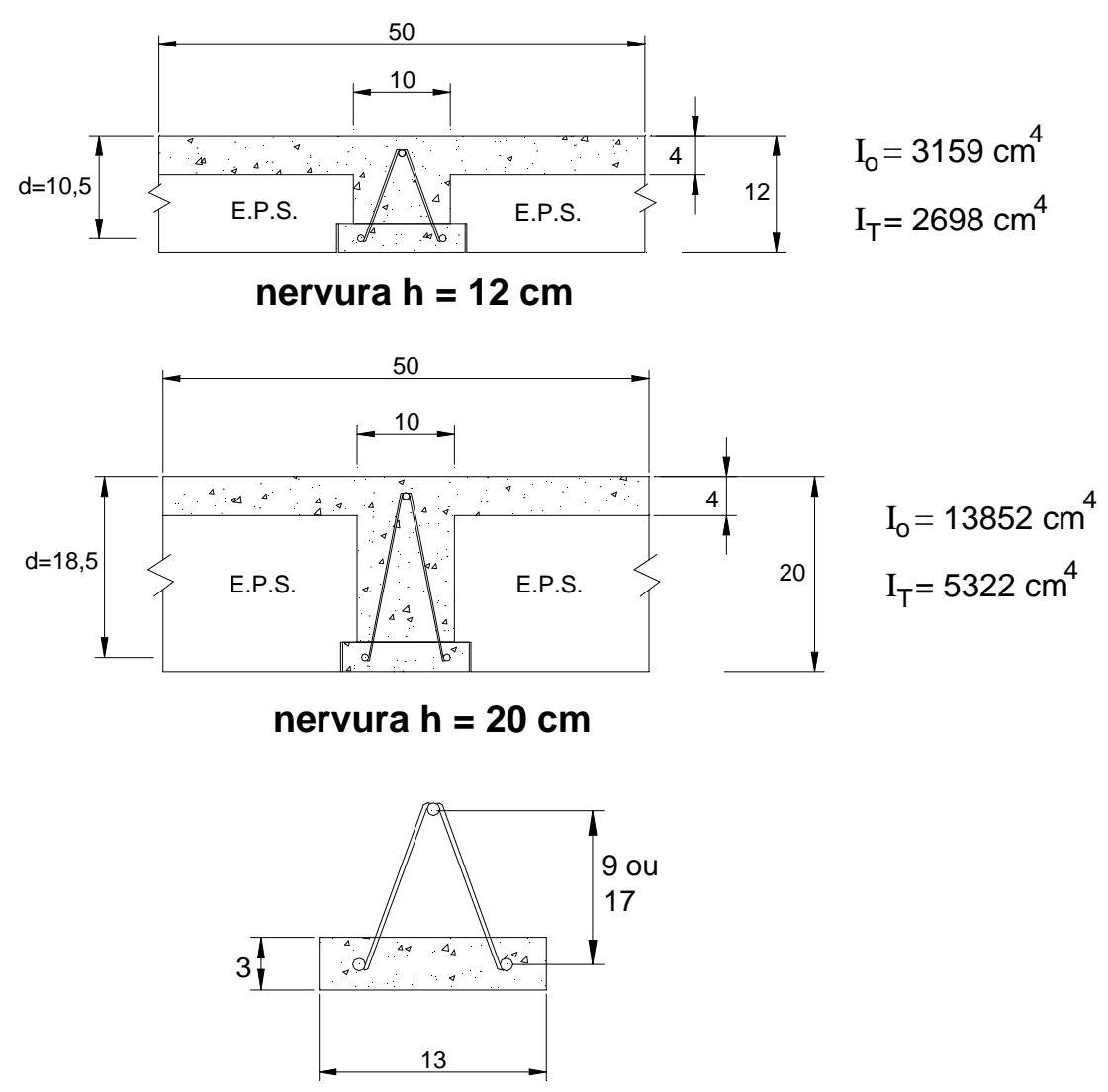

vigota pré-moldada

$I_{O}$ - Momento de inércia à flexão da seção de concreto;

$I_{T}$ - Momento de inércia à torção da seção de concreto.

Fig.6.1 Seção transversal das nervuras longitudinais e da vigota pré-moldada - dimensões em cm

Para os modelos de grelha necessita-se da caracterização dos elementos perpendiculares às nervuras longitudinais, chamados de elementos ou barras transversais da grelha, as seções consideradas são apresentadas na figura 6.2 , sendo para as lajes:

- Laje unidirecional;

- Laje unidirecional com nervuras transversais "nervuras de travamento";

- Laje bidirecional. 


\section{LAJE UNIDIRECIONAL}

contribuição da capa de concreto na direção transversal

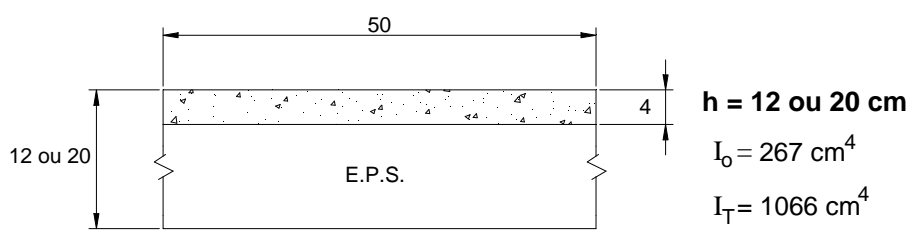

\section{LAJE UNIDIRECIONAL}

nervura transversal

"nervura de travamento"

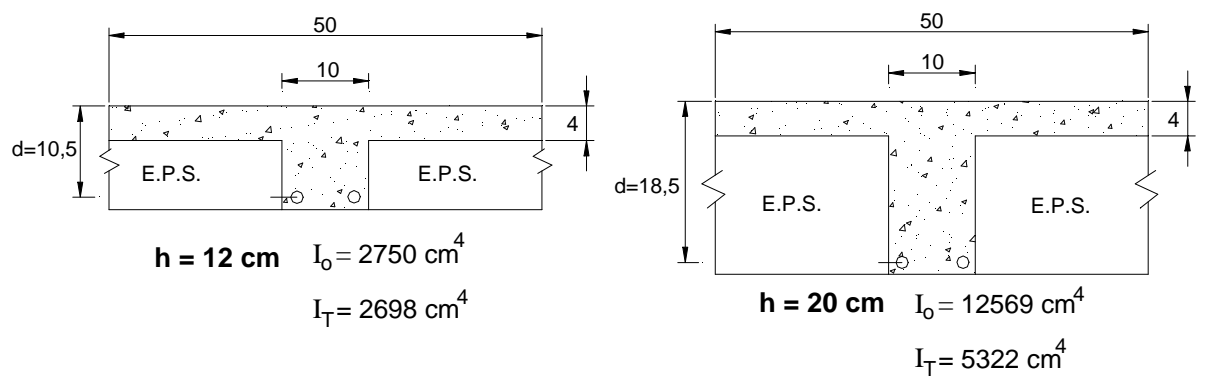

LAJE BIDIRECIONAL

$\mathrm{I}_{\mathrm{T}}=5322 \mathrm{~cm}^{4}$

nervuras transversais

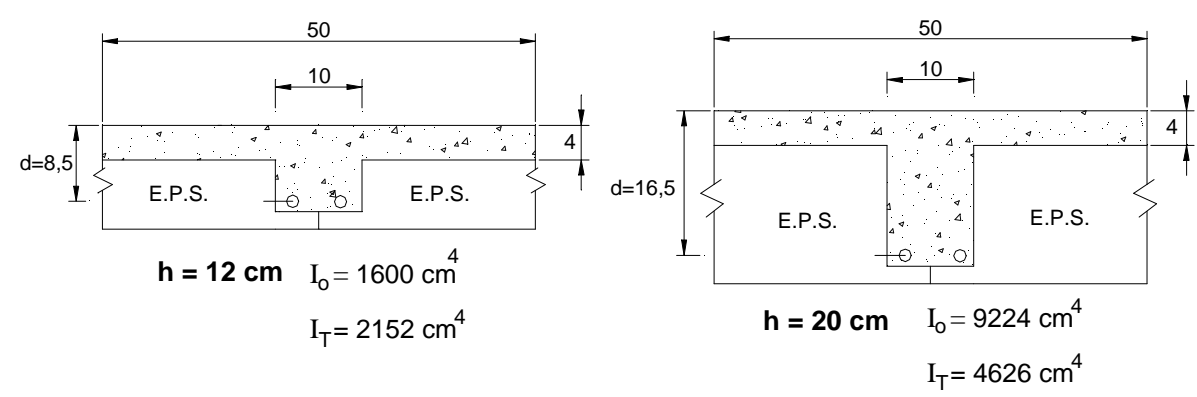

Fig.6.2 Seção transversal das barras transversais - dimensões em cm

Nas análises consideram-se quatro painéis de laje, um com formato quadrado e três retangulares, com o vão $(\ell)$ igual a 6,0 metros. Como pode ser visto na figura 6.3 . 

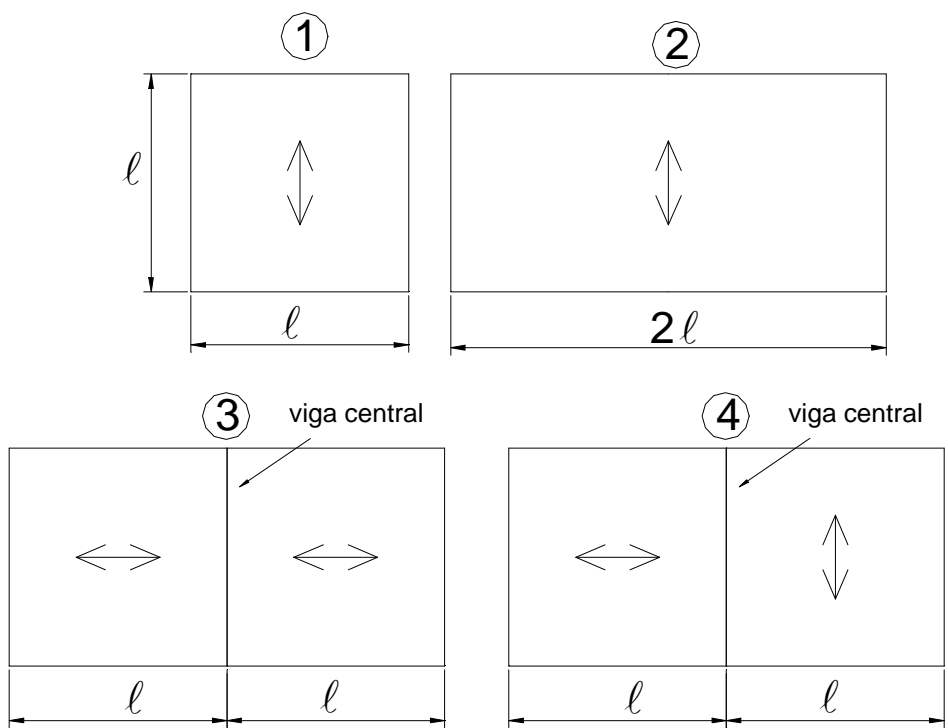

$<>$ sentido das vigotas pré-moldadas

Fig.6.3 Formato das lajes em planta

O primeiro e o segundo arranjos correspondem à laje isolada, o terceiro e o quarto são painéis contínuos.

Por ser uma análise teórica consideram-se os valores médios de resistência do concreto e do aço iguais aos valores característicos $(k)$ destes materiais. O concreto a ser considerado tanto para o moldado no local, quanto para o concreto da vigota pré-moldada será o concreto com resistência média à compressão $\left(f_{c m}\right)$ igual a $20 \mathrm{MPa}$. A armadura da laje será o aço com resistência média à tração $\left(f_{y m}\right)$ igual a 500 ou $600 \mathrm{MPa}$ (CA-50 ou CA-60) e para a armadura das vigas de sustentação da laje igual a $500 \mathrm{MPa}(\mathrm{CA}-50)$.

Segundo o CEB-90 (1991), determinam-se os parâmetros:

$$
E_{C}=27090 \mathrm{MPa} \quad ; \quad E_{C S}=23020 \mathrm{MPa} \quad ; f_{c t m}=2,2 \mathrm{MPa}
$$

Sendo: $E_{S}=210000 \mathrm{MPa} \quad$ tem-se, $\quad E_{S} / E_{C}=7,8$

Como já comentado nos capítulos anteriores, considera-se o início de plastificação do concreto com a deformação do mesmo igual a 1,5 \%o. 
Início de escoamento do aço CA-50 quando o mesmo estiver com a tensão igual a $f_{y m}$ e para o aço CA-60, tensão igual a $0,85 f_{y m}$.

Considera-se a sobrecarga igual a $2,0 \mathrm{kN} / \mathrm{m}^{2}$. O peso próprio é decorrente do peso próprio da laje (vigotas pré-moldadas, concreto moldado no local e elementos de enchimento) e do revestimento. Adota-se revestimento igual a $0,5 \mathrm{kN} / \mathrm{m}^{2}$.

Tabela 6.2 Peso próprio e carregamento total $\left(\mathrm{kN} / \mathrm{m}^{2}\right)$

\begin{tabular}{|c|c|c|c|c|}
\hline $\begin{array}{c}\text { altura da } \\
\text { laje }\end{array}$ & \multicolumn{2}{|c|}{ peso próprio da laje } & \multicolumn{2}{c|}{ carregamento total } \\
\cline { 2 - 5 } & unidirecional & bidirecional & unidirecional & bidirecional \\
\hline $\mathrm{h}=12 \mathrm{~cm}$ & 1,46 & 1,7 & 3,96 & 4,2 \\
\hline $\mathrm{h}=20 \mathrm{~cm}$ & 1,88 & 2,44 & 4,38 & 4,94 \\
\hline
\end{tabular}

Segundo a NBR 6118 (1982), o dimensionamento da estrutura é realizado em função dos esforços solicitantes de cálculo baseado no Estado Limite Último, sendo o coeficiente de majoração das ações igual a 1,4 e os coeficientes de minoração da resistência do concreto e do aço igual a 1,4 e 1,15 , respectivamente.

Para a verificação dos Estados Limites de Utilização, no que diz respeito à verificação de Estados Limites de deformações excessivas podem ser utilizadas as combinações freqüentes das ações:

$$
F_{d}=F_{g}+\Psi_{1} \cdot F_{q 1} \quad \text { com } \Psi_{1} \text { igual a } 0,3
$$

Para as lajes com altura $\mathrm{h}=12 \mathrm{~cm} \mathrm{e} \mathrm{h}=20 \mathrm{~cm}$ temos $F_{d}$ igual a:

a) laje unidirecional

$$
\begin{aligned}
& F_{d(\mathrm{~h}=12)}=1,96+0,3 \times 2=2,56 \mathrm{kN} / \mathrm{m}^{2} \\
& F_{d(\mathrm{~h}=20)}=2,38+0,3 \times 2=2,98 \mathrm{kN} / \mathrm{m}^{2}
\end{aligned}
$$


b) laje bidirecional

$$
\begin{aligned}
& F_{d(\mathrm{~h}=12)}=2,2+0,3 \times 2=2,80 \mathrm{kN} / \mathrm{m}^{2} \\
& F_{d(\mathrm{~h}=20)}=2,94+0,3 \times 2=3,54 \mathrm{kN} / \mathrm{m}^{2}
\end{aligned}
$$

A flecha, medida a partir do plano que passa pelos apoios para vãos sem balanço é de 1/300 do vão considerado. Para os arranjos considerados, tem-se que a flecha máxima em Estado Limite de Utilização será de 600/300 $=2 \mathrm{~cm}$.

Os arranjos adotados para as análises teóricas a seguir, são modelos de viga e de grelha:

a) VIGA

- Viga simplesmente apoiada;

- Viga contínua.

b) GRELHA

- Grelha isolada unidirecional;

- Grelha isolada unidirecional com nervuras transversais "nervuras de travamento";

- Grelha isolada bidirecional;

- Grelha isolada unidirecional e bidirecional com a consideração da rigidez à torção das vigas de extremidade.

- Grelha contínua unidirecional com e sem a consideração da deformabilidade das vigas de sustentação da laje. 


\subsection{ANÁLISE TEÓRICA DAS LAJES UNIDIRECIONAIS MEDIANTE EMPREGO DO MODELO DE VIGA}

\subsubsection{VIGA SIMPLESMENTE APOIADA}

Usualmente, as lajes pré-moldadas unidirecionais, são analisadas e dimensionadas considerando as nervuras como simplesmente apoiadas, sendo o carregamento dado em função do valor da carga (permanente + sobrecarga) por área e do intereixo da laje.

O dimensionamento é feito, então, em função do máximo momento fletor atuante na nervura. Apresenta-se na tabela a seguir o máximo momento fletor atuante na nervura e o dimensionamento dessas nervuras, para o vão de 6,0 metros, considerando o aço CA-50 e o aço CA-60.

Tabela 6.3 Máximo momento fletor e área de aço

\begin{tabular}{|c|c|c|c|c|}
\hline $\mathrm{h}$ & Momento Fletor & $\mathrm{x}$ & \multicolumn{2}{|c|}{ As (cm2) } \\
\cline { 4 - 5 }$(\mathrm{cm})$ & $(\mathrm{kN} . \mathrm{cm})$ & $(\mathrm{cm})$ & $\mathrm{CA}-50$ & $\mathrm{CA}-60$ \\
\hline 12 & 891 & 2,73 & 3,05 & 2,54 \\
\hline 20 & 985 & 1,59 & 1,78 & 1,48 \\
\hline
\end{tabular}

Para o dimensionamento, considerou-se o diagrama retangular de tensões. Nota-se que para as duas alturas a linha neutra $(x)$ está na mesa da seção ( $x<4,0 \mathrm{~cm}=$ altura da mesa de compressão).

Em função da geometria das seções e da área de aço, determinam-se as variáveis necessárias para a análise não-linear (tabela 6.4). Neste seguimento do trabalho, considera-se a inércia à flexão para o estádio II calculada através da homogeneização da seção. Os valores de rigidez à flexão para o estádio II, calculados pela relação momento curvatura, são próximos do calculado pela homogeneização da seção. Lembrando que os valores obtidos pela relação momento curvatura dependem dos valores arbitrados como início de plastificação dos elementos (aço ou concreto). 
Tabela 6.4 Características geométricas e mecânicas das nervuras

\begin{tabular}{|c|c|c|c|c|}
\hline Altura & \multicolumn{2}{|c|}{$\mathrm{h}=12 \mathrm{~cm}$} & $\mathrm{~h}=20 \mathrm{~cm}$ \\
\hline Classe de aço & $\mathrm{CA}-50 \mathrm{~A}$ & $\mathrm{CA}-60 \mathrm{~B}$ & $\mathrm{CA}-50 \mathrm{~A}$ & $\mathrm{CA}-60 \mathrm{~B}$ \\
\hline$A_{s}$ & 3,05 & 2,54 & 1,78 & 1,48 \\
\hline$I_{I}$ & 3997 & 3865 & 15473 & 15207 \\
\hline$I_{I I}$ & 1775 & 1528 & 3785 & 3210 \\
\hline$M r$ & 138,1 & 132,3 & 317,0 & 310,1 \\
\hline Escoamento ou plastificação & ARMAD & ARMAD & ARMAD & ARMAD \\
\hline$M y$ & 1421,01 & 1228,83 & 1539,87 & 1319,34 \\
\hline $1 / r y$ & 0,00033 & 0,00038 & 0,00016 & 0,00019 \\
\hline Momento fletor último & DOM2B & DOM2B & DOM2A & DOM2A \\
\hline$M u$ & 1477,2 & 1476,2 & 1586,8 & 1582,3 \\
\hline $1 / r u$ & 0,00119 & 0,00119 & 0,00060 & 0,00060 \\
\hline
\end{tabular}

$A_{s}$ - Área de aço $\left(\mathrm{cm}^{2}\right)$

$I_{I}, l_{I I}$ - Momento de inércia à flexão $\left(\mathrm{cm}^{4}\right)$ para o estádio I e para o estádio II;

$M_{r}, M_{y}, M_{u}$ - Momento fletor $(\mathrm{kN} . \mathrm{cm})$ de início de fissuração, de plastificação e último;

$1 / r_{y}, 1 / r_{u}$ - Curvatura $\left(\mathrm{cm}^{-1}\right)$ referente ao momento de plastificação e momento último.

Tem-se o carregamento distribuído igual a 2,0 e 2,2 kN/m, para as nervuras com altura 12 e $20 \mathrm{~cm}$, respectivamente. Dividem-se estes carregamentos em 15 incrementos e realiza-se a análise não-linear. Esta análise não termina no incremento número 15 , pois neste, tem-se apenas o valor do carregamento que gera o momento fletor característico $\left(M_{k}\right)$, a análise é finalizada quando atingir o momento último $\left(M_{u}\right)$. Divide-se a viga em 12 elementos, cada qual com $50 \mathrm{~cm}$ de comprimento.

Apresentam-se nos diagramas a seguir (figuras 6.4 e 6.5), os resultados da análise não-linear da nervura simplesmente apoiada segundo as formulações do CEB-90 (1991) e também segundo a formulação de BRANSON (1963). Têm-se como principais variáveis a serem comparadas a altura da viga e o tipo de aço, CA-50 A ou CA-60 B. 


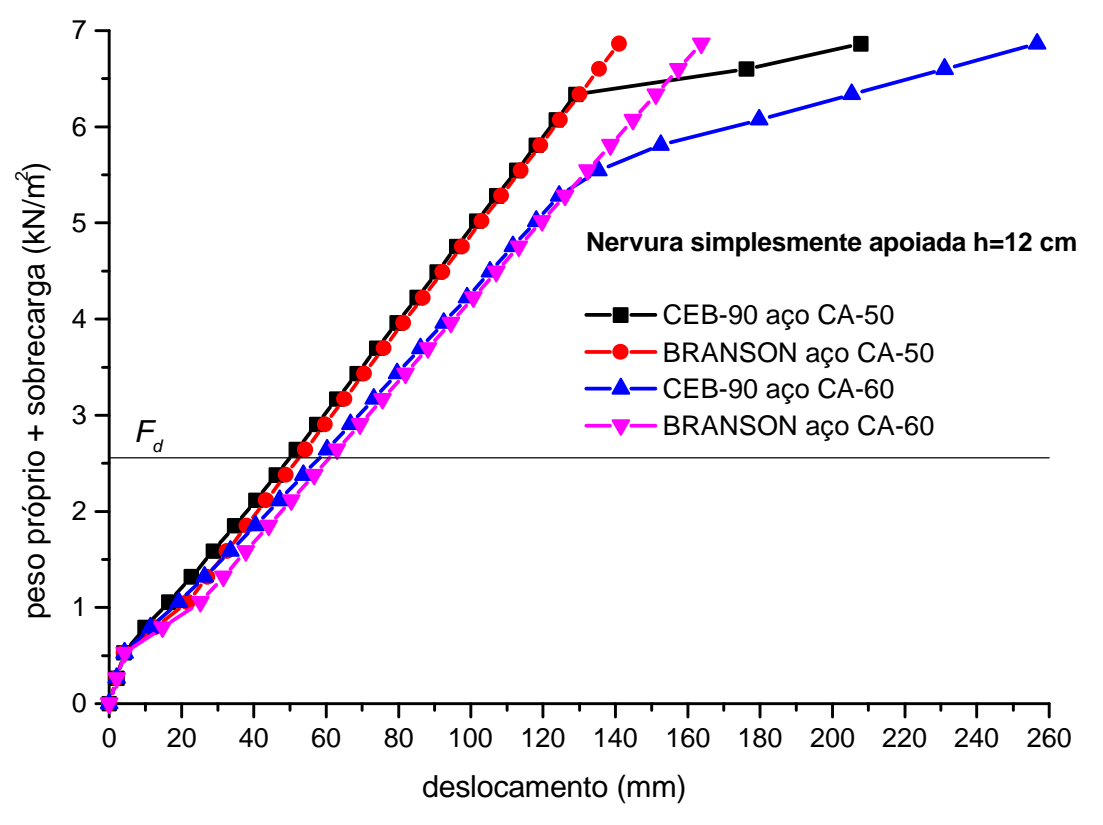

Fig.6.4 Carregamento $x$ deslocamento - nervura simplesmente apoiada $-\mathrm{h}=12 \mathrm{~cm}$

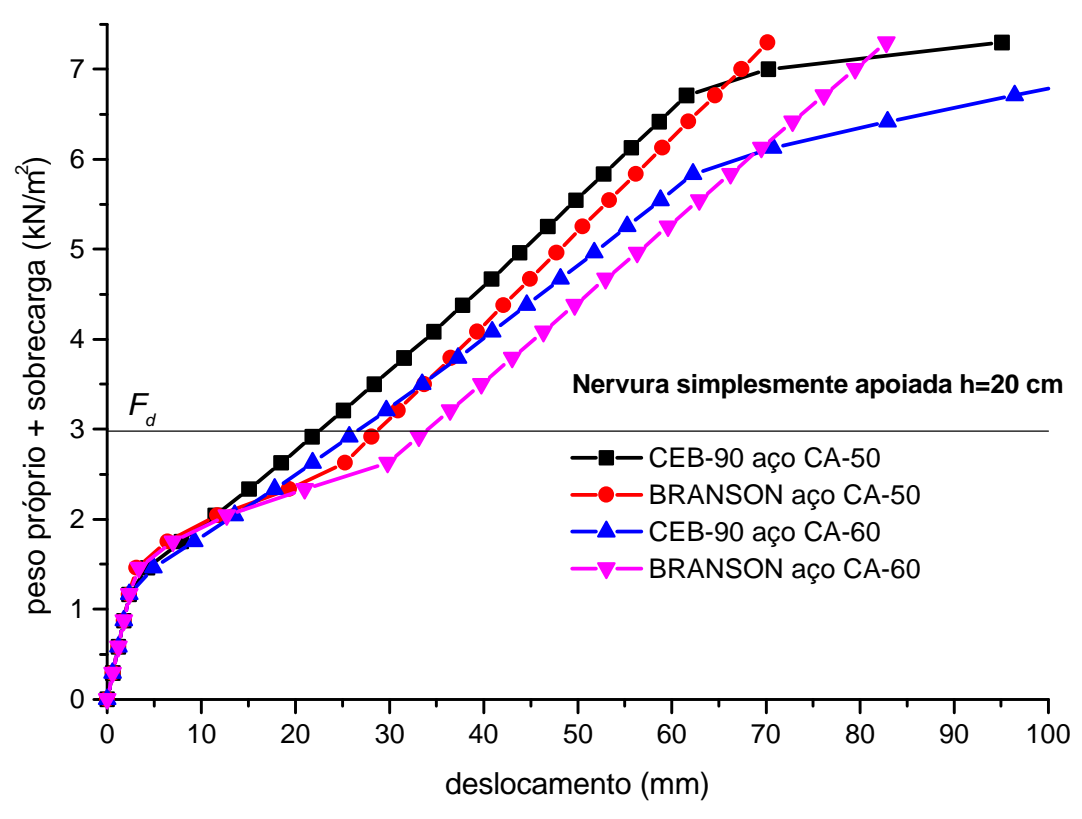

Fig.6.5 Carregamento $x$ deslocamento - nervura simplesmente apoiada $-\mathrm{h}=20 \mathrm{~cm}$ 


\subsubsection{VIGA CONTÍNUA}

Geralmente as lajes pré-moldadas são dimensionadas como painéis independentes, ou seja, não se considera a continuidade entre as lajes adjacentes.

Nesta análise deseja-se verificar esta continuidade e o valor da rigidez à flexão que ocorre em vigas "T" em função de o momento fletor ser positivo ou negativo, ou seja, para mesa comprimida e tracionada.

Considera-se, nesta análise, o momento fletor determinado em regime elástico linear em dois vãos consecutivos de 6,0 metros e fazem-se reduções do momento fletor negativo em 15 e $50 \%$. Para cada caso, dimensiona-se a armadura em função do máximo momento fletor positivo e negativo (figura 6.6) e faz-se a análise não-linear.

O dimensionamento da nervura sujeita a momentos positivos, faz-se considerando como uma viga "T", agora para os momentos negativos, considera-se somente a largura da alma da nervura " $b_{w}$ ", conforme pode ser visto em 3.5.1.

São apresentados na tabela 6.5 as características geométricas e mecânicas das seções transversais em função do momento fletor atuante e das suas alterações (redução do momento fletor negativo).

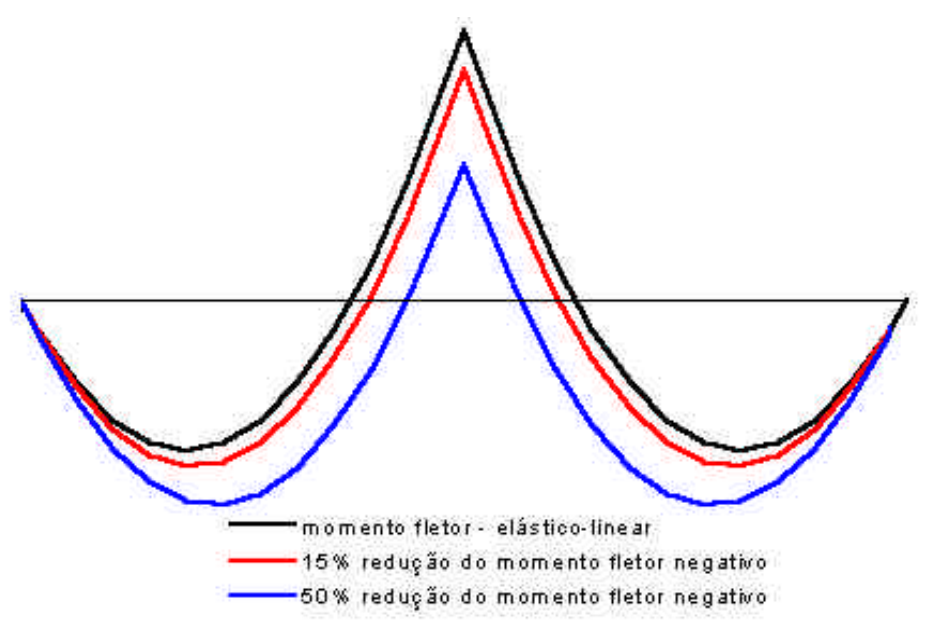

Fig.6.6 Diagrama de momento fletor determinado em regime elástico linear e diagramas obtidos com a redução do momento fletor negativo 
Tabela 6.5 Características geométricas e mecânicas da nervura contínua

\begin{tabular}{|c|c|c|c|c|}
\hline S/ redução mom. fletor negativo & \multicolumn{2}{|c|}{$\mathrm{h}=12(\mathrm{~cm})$} & \multicolumn{2}{c|}{$\mathrm{h}=20(\mathrm{~cm})$} \\
\hline Momento fletor & 501 & -891 & 554 & -985 \\
\hline$A s$ & 1,35 & 2,67 & 0,81 & 1,70 \\
\hline$A s 2$ & 0,00 & 2,21 & 0,00 & 0,22 \\
\hline$I_{I}$ & 3544 & 3907 & 14603 & 14371 \\
\hline$I_{I}$ & 893 & 1183 & 1853 & 2816 \\
\hline$M r$ & 118,8 & 252,1 & 294,6 & 572,5 \\
\hline Escoamento ou plastificação & ARMAD & CONCR & ARMAD & CONCR \\
\hline$M y$ & 672,42 & 899,57 & 732,99 & 1324,80 \\
\hline $1 / r y$ & 0,00035 & 0,00031 & 0,00018 & 0,00022 \\
\hline Momento fletor último & DOM2A & DOM3 & DOM2A & DOM3 \\
\hline$M u$ & 809,0 & 1435,3 & 876,0 & 1656,7 \\
\hline $1 / r u$ & 0,00110 & 0,00091 & 0,00058 & 0,00062 \\
\hline
\end{tabular}

\begin{tabular}{|c|c|c|c|c|}
\hline 15\% redução mom.fletor negativo & \multicolumn{2}{|c|}{$\mathrm{h}=12(\mathrm{~cm})$} & \multicolumn{2}{c|}{$\mathrm{h}=20(\mathrm{~cm})$} \\
\hline Momento fletor & 553 & -757 & 611 & -837 \\
\hline$A s$ & 1,51 & 2,40 & 0,91 & 1,50 \\
\hline$A s 2$ & 0,00 & 1,95 & 0,00 & 0,00 \\
\hline$I_{I}$ & 3588 & 3783 & 14694 & 14085 \\
\hline$I_{I I} r$ & 984 & 970 & 2063 & 2382 \\
\hline$M r$ & 120,6 & 243,6 & 296,9 & 562,6 \\
\hline Escoamento ou plastificação & ARMAD & CONCR & ARMAD & CONCR \\
\hline$M y$ & 749,18 & 773,66 & 821,28 & 1148,50 \\
\hline $1 / r y$ & 0,00035 & 0,00033 & 0,00018 & 0,00023 \\
\hline Momento fletor último & DOM2A & DOM3 & DOM2A & DOM3 \\
\hline$M u$ & 901,4 & 1222,1 & 982,1 & 1411,9 \\
\hline $1 / r u$ & 0,00111 & 0,00095 & 0,00059 & 0,00063 \\
\hline
\end{tabular}

\begin{tabular}{|c|c|c|c|c|}
\hline 50\% redução mom. fletor negativo & \multicolumn{2}{|c|}{$\mathrm{h}=12(\mathrm{~cm})$} & \multicolumn{2}{c|}{$\mathrm{h}=20(\mathrm{~cm})$} \\
\hline Momento fletor & 682 & -446 & 754 & -492 \\
\hline$A s$ & 1,89 & 1,42 & 1,12 & 0,81 \\
\hline$A s 2$ & 0,00 & 0,74 & 0,00 & 0,00 \\
\hline$I_{I}$ & 3692 & 3412 & 14884 & 13975 \\
\hline$I_{I I}$ & 1193 & 631 & 2495 & 1450 \\
\hline$M r$ & 124,9 & 226,9 & 301,8 & 553,1 \\
\hline Escoamento ou plastificação & ARMAD & CONCR & ARMAD & ARMAD \\
\hline$M y$ & 928,36 & 525,63 & 1005,95 & 674,47 \\
\hline $1 / r y$ & 0,00037 & 0,00036 & 0,00018 & 0,00022 \\
\hline Momento fletor último & DOM2A & DOM3 & DOM2A & DOM2B \\
\hline$M u$ & 1117,5 & 729,2 & 1204,9 & 811,0 \\
\hline $1 / r u$ & 0,00114 & 0,00103 & 0,00059 & 0,00069 \\
\hline
\end{tabular}

A análise não linear com continuidade é feita do mesmo modo que para as lajes e vigas simplesmente apoiadas, como foi enunciado em 3.5.1. Diferenciando-se apenas em que, durante a análise não-linear incremental, em um determinado elemento, se o momento fletor for positivo, determina-se 
a rigidez em função da seção transversal dimensionada para resistir ao momento fletor positivo, caso contrário, determina-se a rigidez em função da seção transversal dimensionada ao momento fletor negativo. Do mesmo modo que para as vigas simplesmente apoiadas, consideram-se os elementos com $50 \mathrm{~cm}$ de comprimento.

A seguir, apresenta-se na figura 6.7 o diagrama de carregamento $x$ deslocamento para as vigas contínuas. $\mathrm{O}$ último ponto de cada diagrama refere-se a atuação do carregamento que atinge o Estado Limite Último ou momento fletor último da seção de concreto armado. Para verificar se há redistribuição de esforços, mostra-se nas figuras 6.8 e 6.9 o diagrama com a variação do máximo valor de momento fletor negativo em função do carregamento.

Na tabela 6.6 mostra-se a relação ou razão entre o momento fletor negativo (análise linear) e momento fletor negativo último (análise nãolinear).

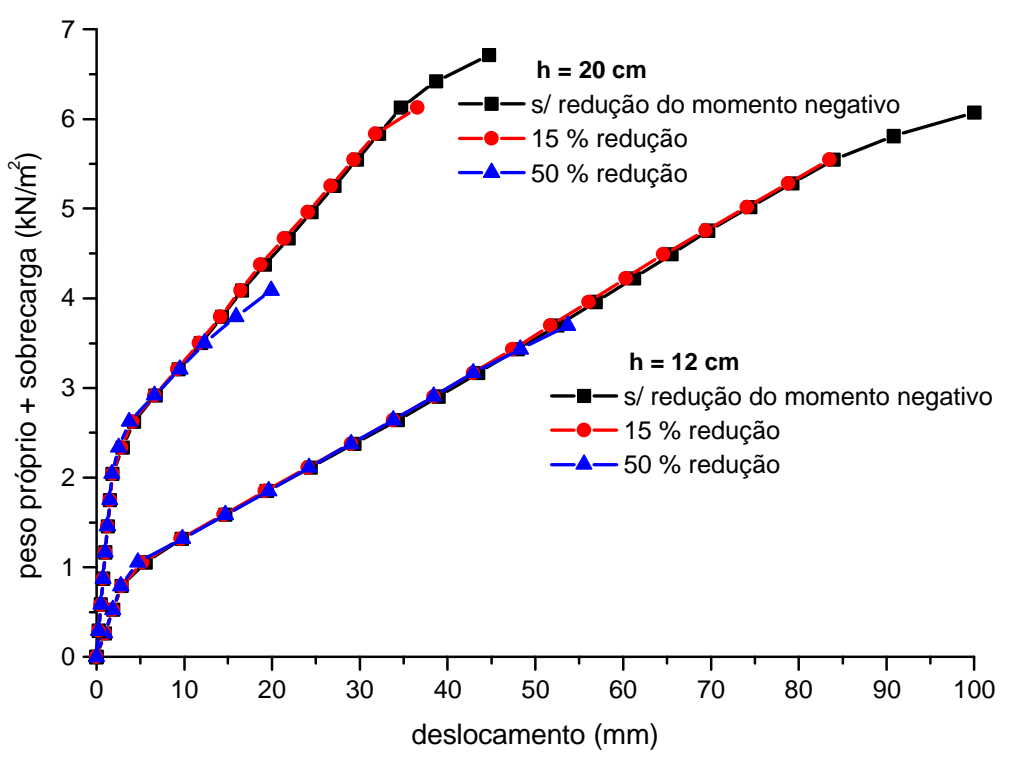

Fig.6.7 Carregamento x deslocamento -nevrura contínua - $\mathrm{h}=12$ e $20 \mathrm{~cm}$ 


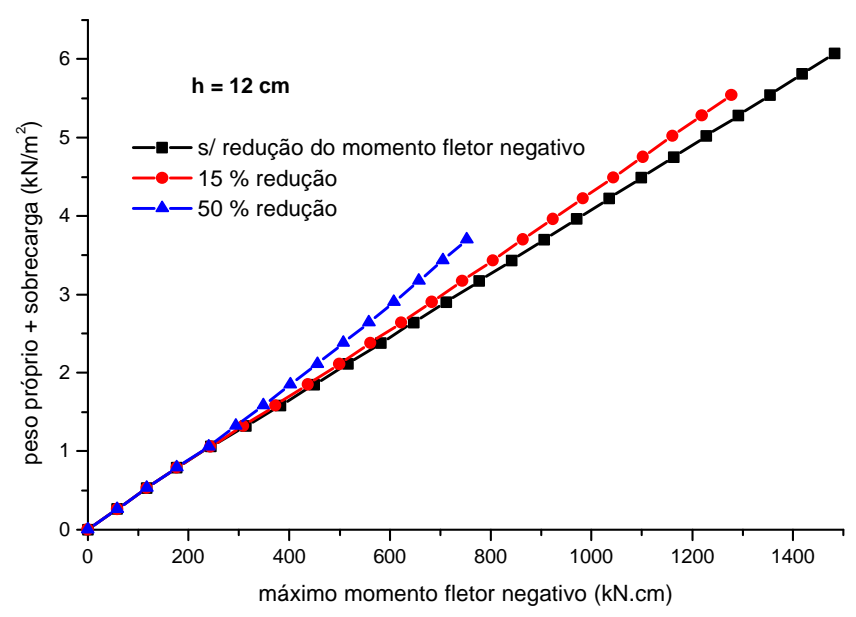

Fig.6.8 Variação do máximo momento fletor negativo laje $\mathrm{h}=12 \mathrm{~cm}$ - análise não-linear

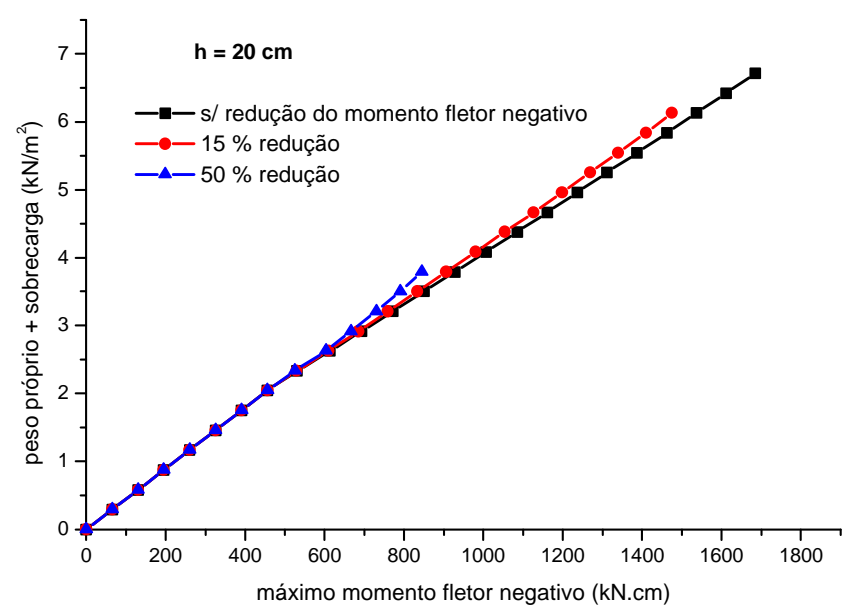

Fig.6.9 Variação do máximo momento fletor negativo laje $\mathrm{h}=20 \mathrm{~cm}$ - análise não-linear

Tabela 6.6 Relação do momento negativo obtido pela análise não linear pelo momento negativo considerado para o dimensionamento da seção.

\begin{tabular}{|c|c|c|c|}
\hline $\begin{array}{c}\text { altura da } \\
\text { laje }(\mathrm{cm})\end{array}$ & s/ redução & $15 \%$ redução & $50 \%$ redução \\
\cline { 2 - 4 } & MNL./ 1,0. ML & MNL./ 0,85. ML & MNL./ 0,5. ML \\
\hline $\mathrm{h}=12$ & 1,08 & 1,20 & 1,80 \\
\hline $\mathrm{h}=20$ & 1,12 & 1,26 & 1,98 \\
\hline
\end{tabular}

MNL - Momento fletor negativo (análise não-linear)

$\mathrm{ML}$ - Momento fletor negativo (análise linear) 


\subsubsection{ANÁLISE DOS RESULTADOS}

A análise teórica da laje pré-moldada apresentada neste item é referente aos modelos de viga. Nestes modelos têm-se como parâmetros principais o momento fletor e a rigidez à flexão.

$\mathrm{Na}$ primeira análise há a nervura simplesmente apoiada, dimensionada com o aço CA-50 e CA-60, pois em muitos casos, os dois tipos de classe de armadura trabalham conjuntamente. Utilizando-se a classe CA-60 o maior deslocamento, em serviço, é cerca de $17 \%$ maior do que com o aço CA-50.

Para a laje $\mathrm{h}=12 \mathrm{~cm}$, os valores de deslocamentos calculados pelos modelos do CEB-90 e de BRANSON foram próximos. Agora para $h=20 \mathrm{~cm}$, há sensíveis diferenças de valores como pode ser visto na figura 6.5.

Para a viga ou nervura contínua, o dimensionamento da nervura em função dos valores de momento fletor obtidos, seja pela redução do momento negativo ( $15 \%$ e $50 \%$, por exemplo) obtido através da análise linear com inércia constante, ou por imposições de valores. Nota-se (tabela 6.6) que há grandes discrepâncias entre os valores de momento fletor utilizado para o dimensionamento e os valores obtidos com análise nãolinear.

Até mesmo na análise sem a redução do momento negativo, há discrepâncias entre os valores de momento fletor. Isto ocorre pelo fato de que a rigidez da seção submetida ao momento negativo é maior do que a da seção submetida ao momento positivo, há um maior momento fletor negativo, do que o calculado pela análise linear com inércia constante.

Com o dimensionamento da seção em função de valores de momento fletor reduzidos ou arbitrados, ocorre também a redução do momento negativo calculado pela análise não-linear, mas não na mesma intensidade da redução imposta no dimensionamento. Pois do mesmo modo que ocorre a redução da rigidez à flexão nos elementos devido à atuação do momento fletor negativo, ocorre também a redução da rigidez devido à atuação do momento fletor positivo e com isso, há uma pouca redistribuição 
de esforços, chegando-se a valores próximos dos obtidos através da análise elástica linear.

Nas figuras 6.8 e 6.9 pode-se notar a pequena variação do máximo valor do momento fletor negativo, através da análise não-linear (carregamento incremental). Na tabela 6.6 nota-se que mesmo com o dimensionamento da seção em $85 \%$ do momento negativo tem-se através da análise não-linear, valores acima de 100\% do momento negativo da análise linear. Com a redução em $50 \%$ do momento fletor negativo, ocorrem reduções de apenas 10 e $1 \%$ do momento fletor negativo para as lajes com altura 12 e $20 \mathrm{~cm}$ respectivamente.

À medida que se arbitra um valor do momento negativo menor do que o calculado através da análise linear com inércia constante, aumentam as diferenças entre o valor do momento fletor utilizado para o dimensionamento da seção com o valor provável do momento fletor presente na estrutura.

Um fato a ressaltar é que, com imposições de momento fletor negativo menor do que o calculado pela análise linear, o dimensionamento irá apresentar uma seção com menor valor de resistência ao momento fletor último, ocorrendo, segundo o modelo adotado, o estado limite último com pequenos carregamentos, como pode ser visto na figura 6.7.

Outro fato a ressaltar é que neste dimensionamento da nervura submetida ao momento fletor negativo, considera-se a resistência à compressão do concreto moldado no local e o concreto da vigota. Com isso, admite-se que exista perfeita aderência entre os concretos e que também a resistência entre eles seja próxima. 


\subsection{ANÁLISE TEÓRICA DAS LAJES UNIDIRECIONAIS E BIDIRECIONAIS MEDIANTE O EMPREGO DO MODELO DE GRELHA}

\subsubsection{GRELHA ISOLADA}

$\mathrm{Na}$ análise segundo modelos de grelha, além da influência da rigidez à flexão dos elementos constituintes, há também a influência da rigidez à torção.

O desconhecimento da capacidade das lajes nervuradas para absorver momentos de torção e também a não necessidade da sua consideração para o equilíbrio da grelha, faz com que se desprezem ou adotem valores muito baixos dessa rigidez.

A seguir apresentam-se as variações de momento fletor que ocorrem ao se considerar ou não a rigidez à torção das nervuras longitudinais e transversais em uma laje unidirecional, representada pela grelha com as seções transversais indicadas na figura 6.10.

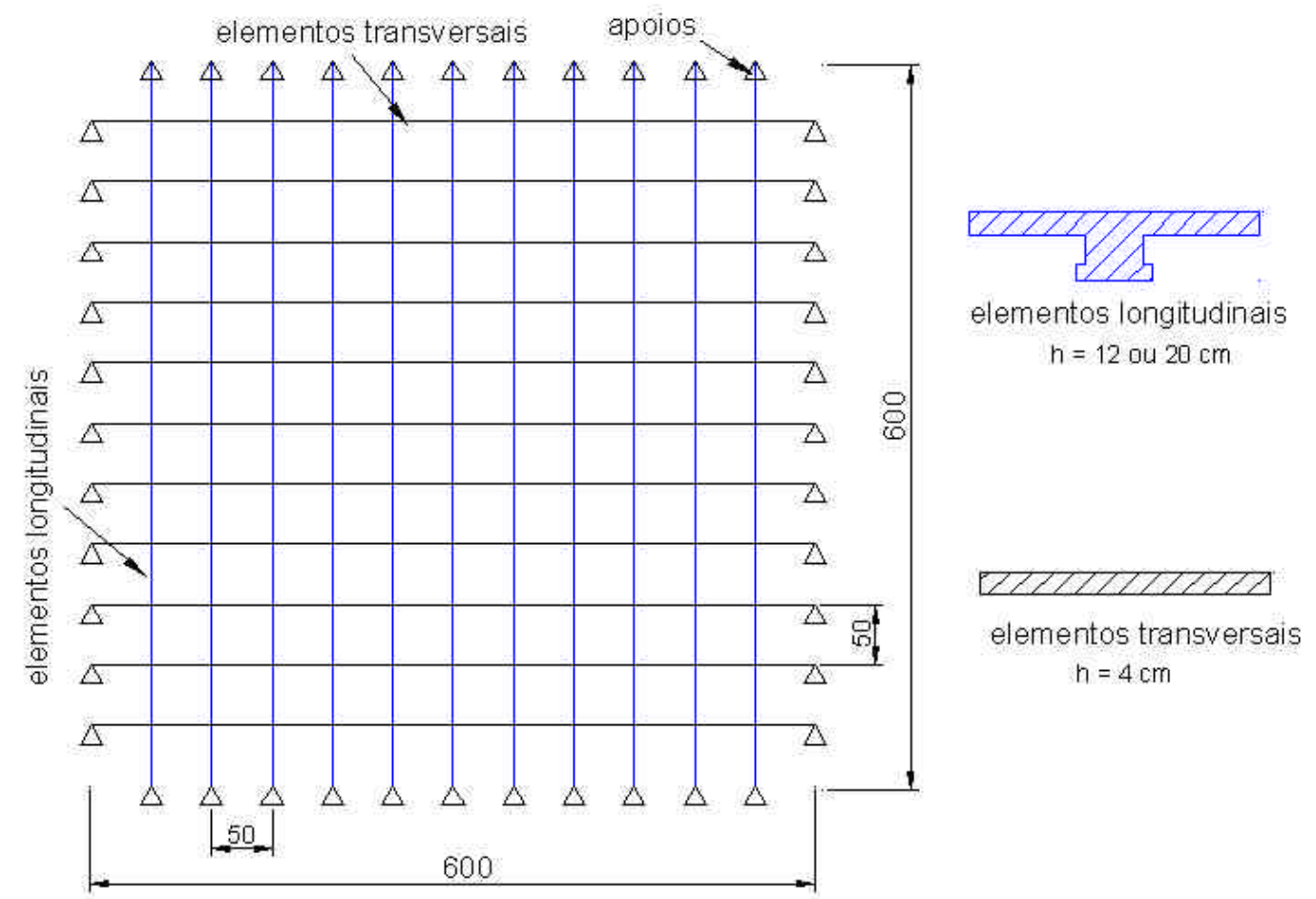

Fig.6.10 Grelha e os elementos constituintes laje nervurada unidirecional 
Apresenta-se nos gráficos a seguir o momento fletor na nervura longitudinal, segundo análise linear, para três considerações da rigidez à torção:

- rigidez à torção para o estádio I;

- $\quad$ rigidez à torção para o estádio II;

- rigidez à torção igual a zero

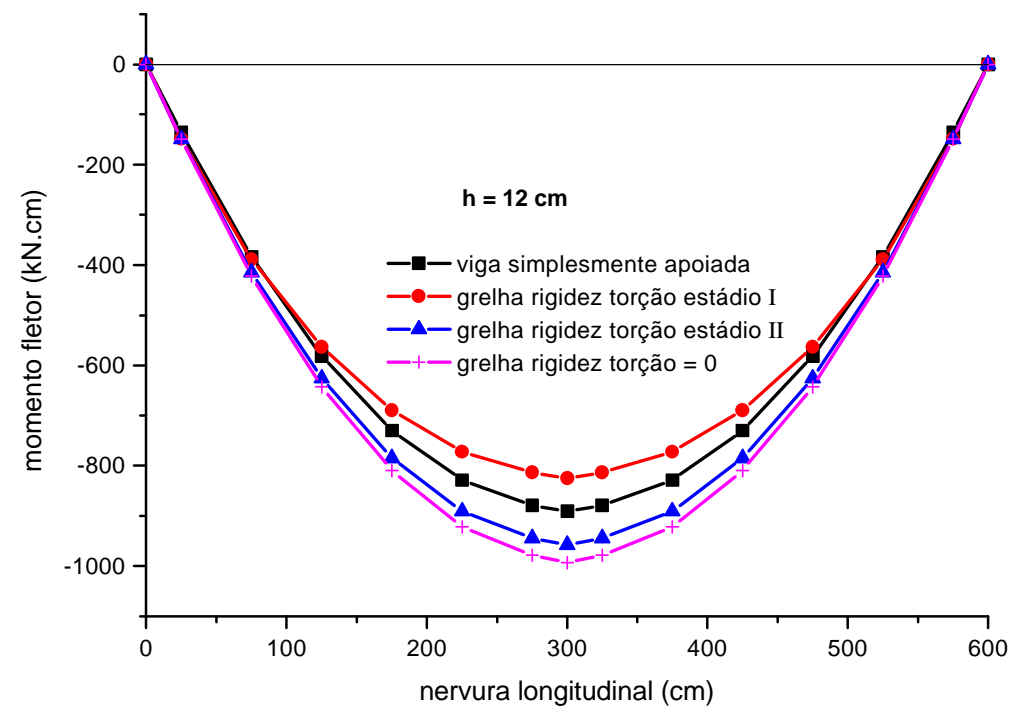

Fig.6.11 Diagrama de momento fletor $-\mathrm{h}=12 \mathrm{~cm}$

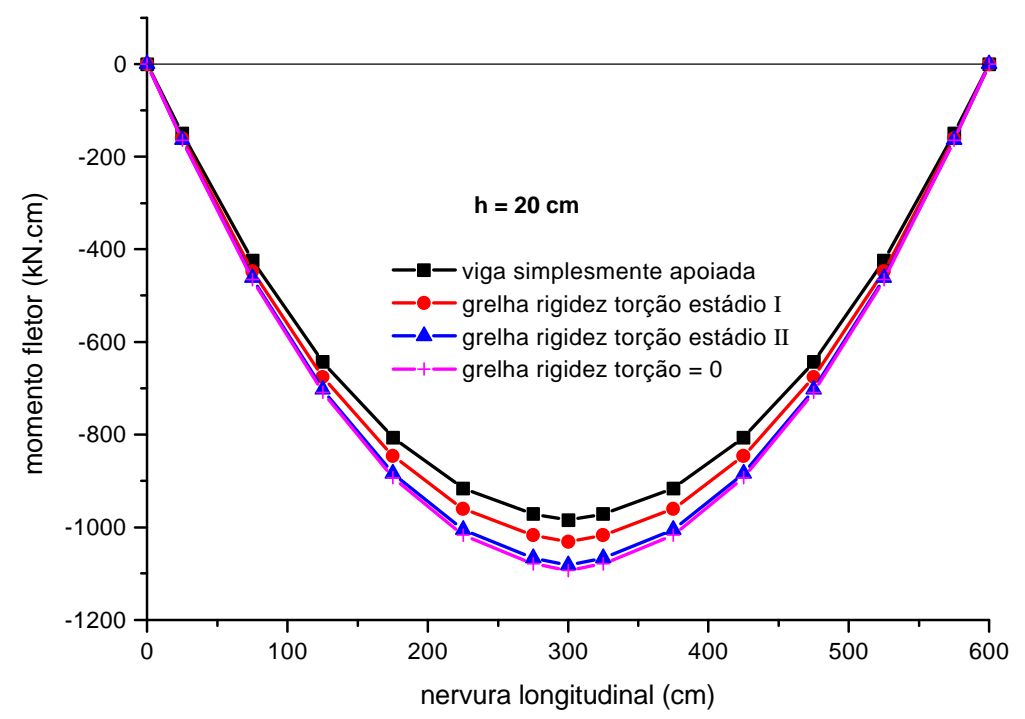

Fig.6.12 Diagrama de Momento Fletor $-\mathrm{h}=20 \mathrm{~cm}$ 
Nota-se que o máximo valor de momento fletor na nervura longitudinal calculada como grelha é maior do que o caso de se calcular como viga simplesmente apoiada. A princípio este resultado não era esperado, pois ao introduzir rigidez na direção transversal é esperado que o momento fletor na direção longitudinal diminua. Este resultado adverso ocorre devido à grande diferença de rigidez existente entre as nervuras longitudinais e transversais.

Para verificar a influência da rigidez à flexão da nervura transversal no valor de momento fletor da nervura longitudinal apresenta-se nos gráficos a seguir, através de análise linear, a variação do máximo momento fletor que ocorre na nervura longitudinal em função da variação do momento de inércia à flexão da nervura transversal. Para esta análise considera-se um valor desprezível para a rigidez à torção, pois se pretende analisar somente a influência da rigidez à flexão. Adotam-se dois tipos de grelha, a com formato quadrado $(6,0 \mathrm{~m} \times 6,0 \mathrm{~m})$ e a retangular $(12,0 \mathrm{~m} \times 6,0 \mathrm{~m})$, sendo que nesta as nervuras longitudinais (c/ vigotas pré-moldadas) são dispostas no menor vão.

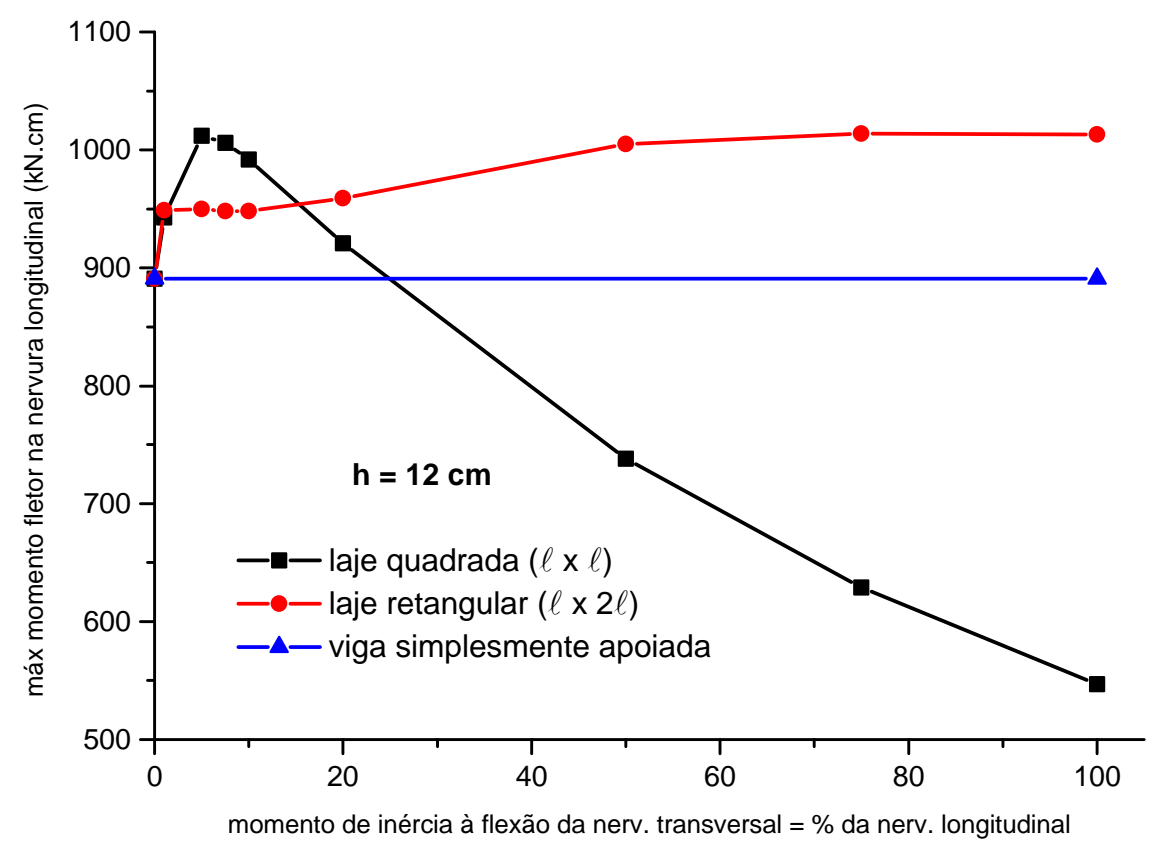

Fig.6.13 Variação do máximo momento fletor na nervura longitudinal em função da rigidez da nervura transversal $-\mathrm{h}=12 \mathrm{~cm}$ 


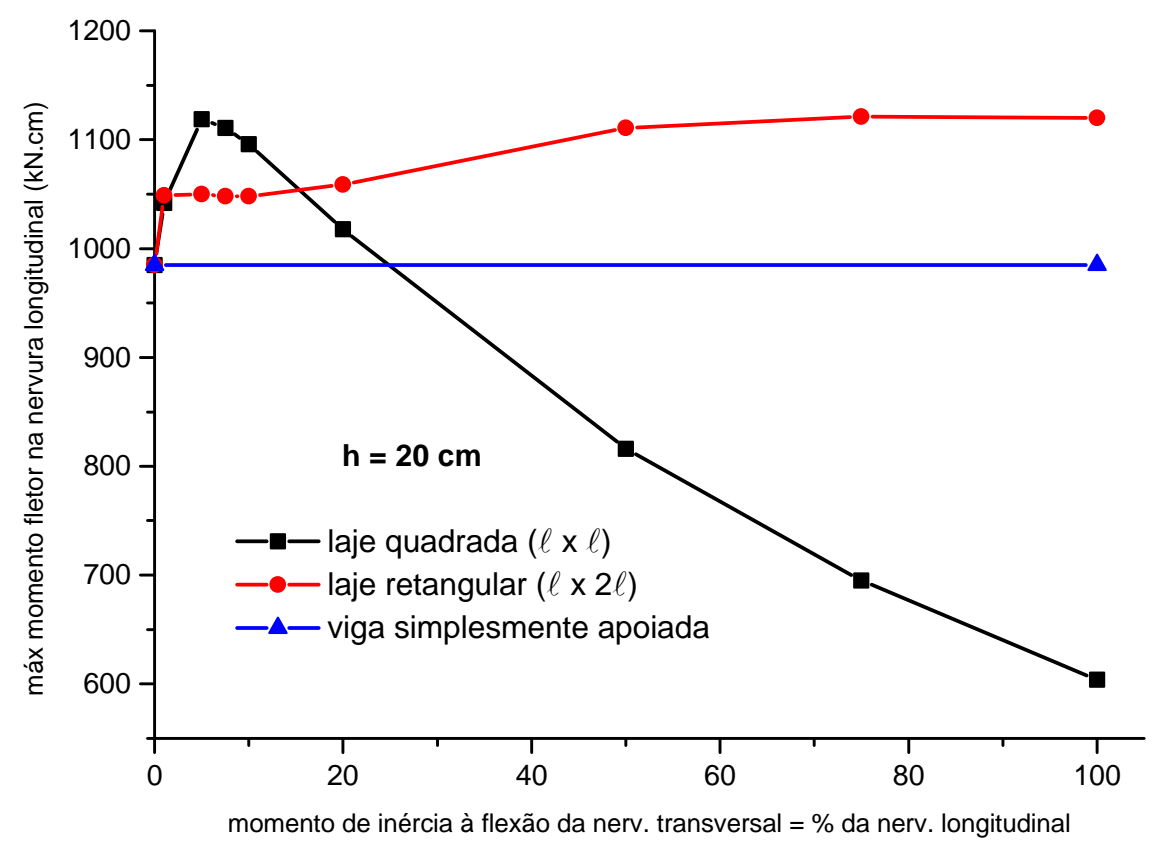

Fig.6.14 Variação do máximo momento fletor na nervura longitudinal em função da rigidez da nervura transversal $-\mathrm{h}=20 \mathrm{~cm}$

Para uma melhor verificação da influência da rigidez das nervuras transversais nos valores de momento fletor, apresentam-se nas figuras 6.15 a 6.18, os diagramas de momento fletor, via tela gráfica do ANSYS ${ }^{\circledR}$, para a grelha retangular (12,0 m x 6,0 m). Nestes, consideram-se a inércia à flexão na direção transversal igual a $0,10,50$ e 100 por cento da inércia à flexão na direção longitudinal. 


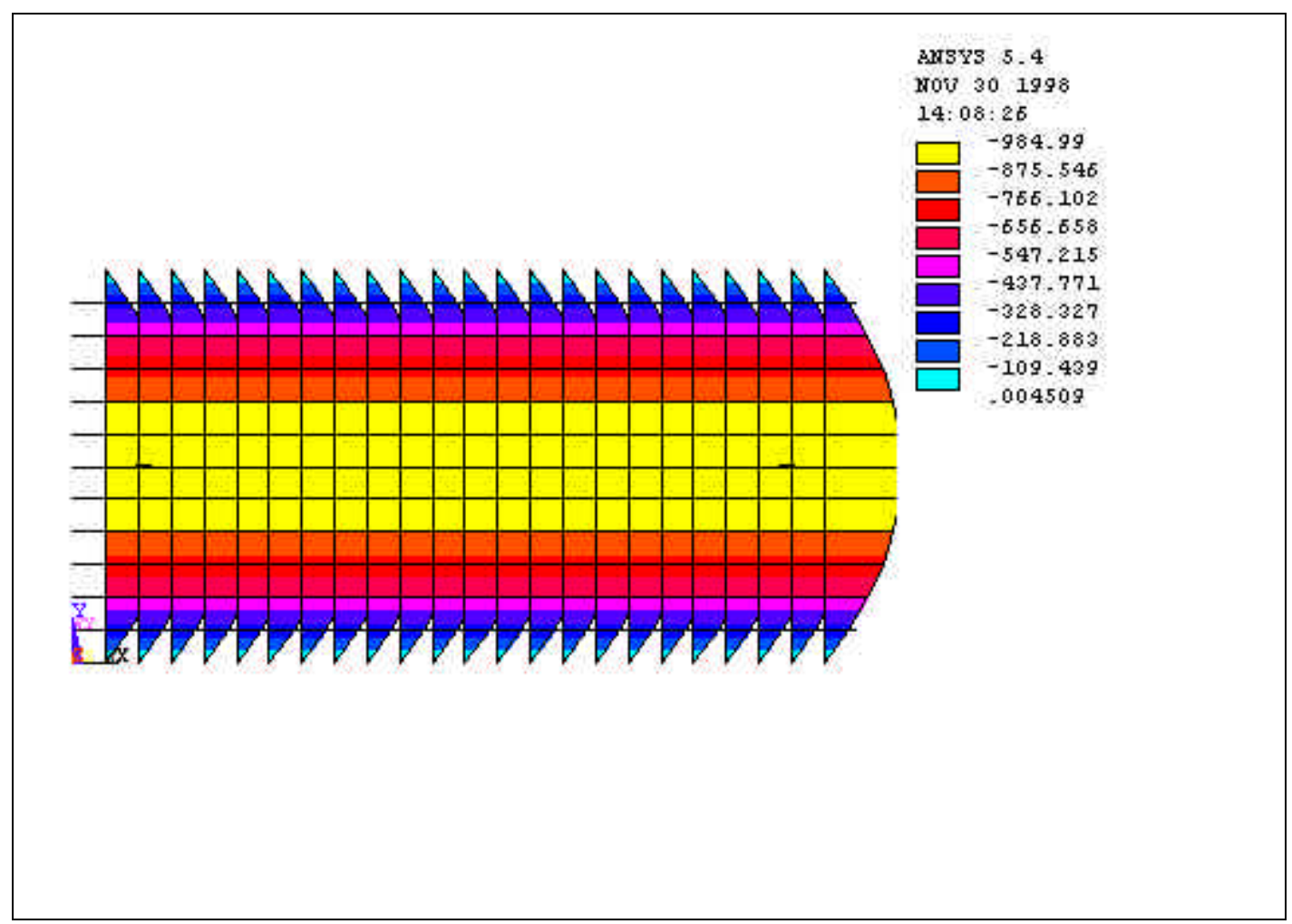

Fig.6.15 Diagrama de momento fletor-inércia à flexão transversal igual a $0 \%$ da inércia à flexão longitudinal

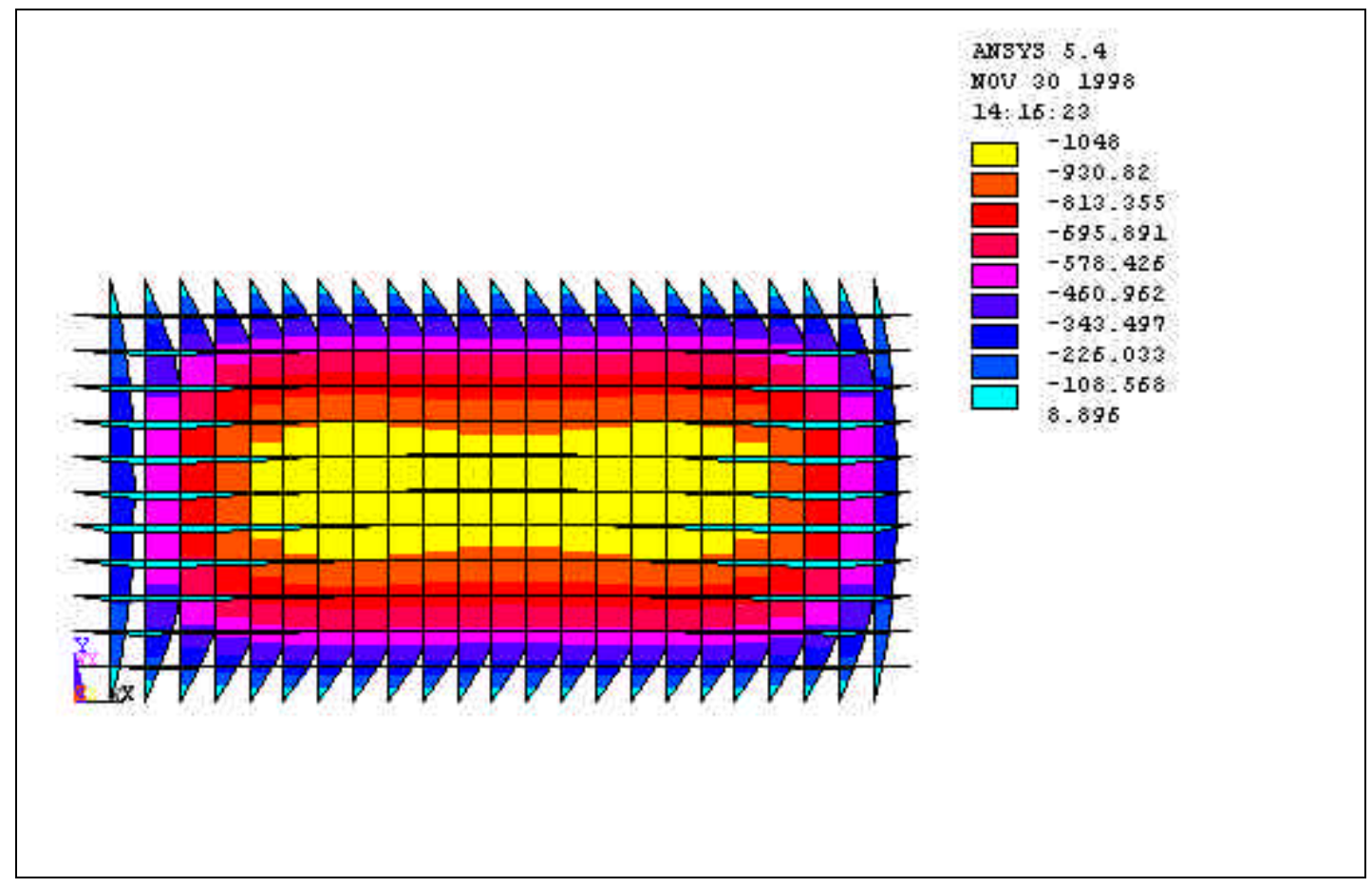

Fig.6.16 Diagrama de momento fletor-inércia à flexão transversal igual a $10 \%$ da inércia à flexão longitudinal 


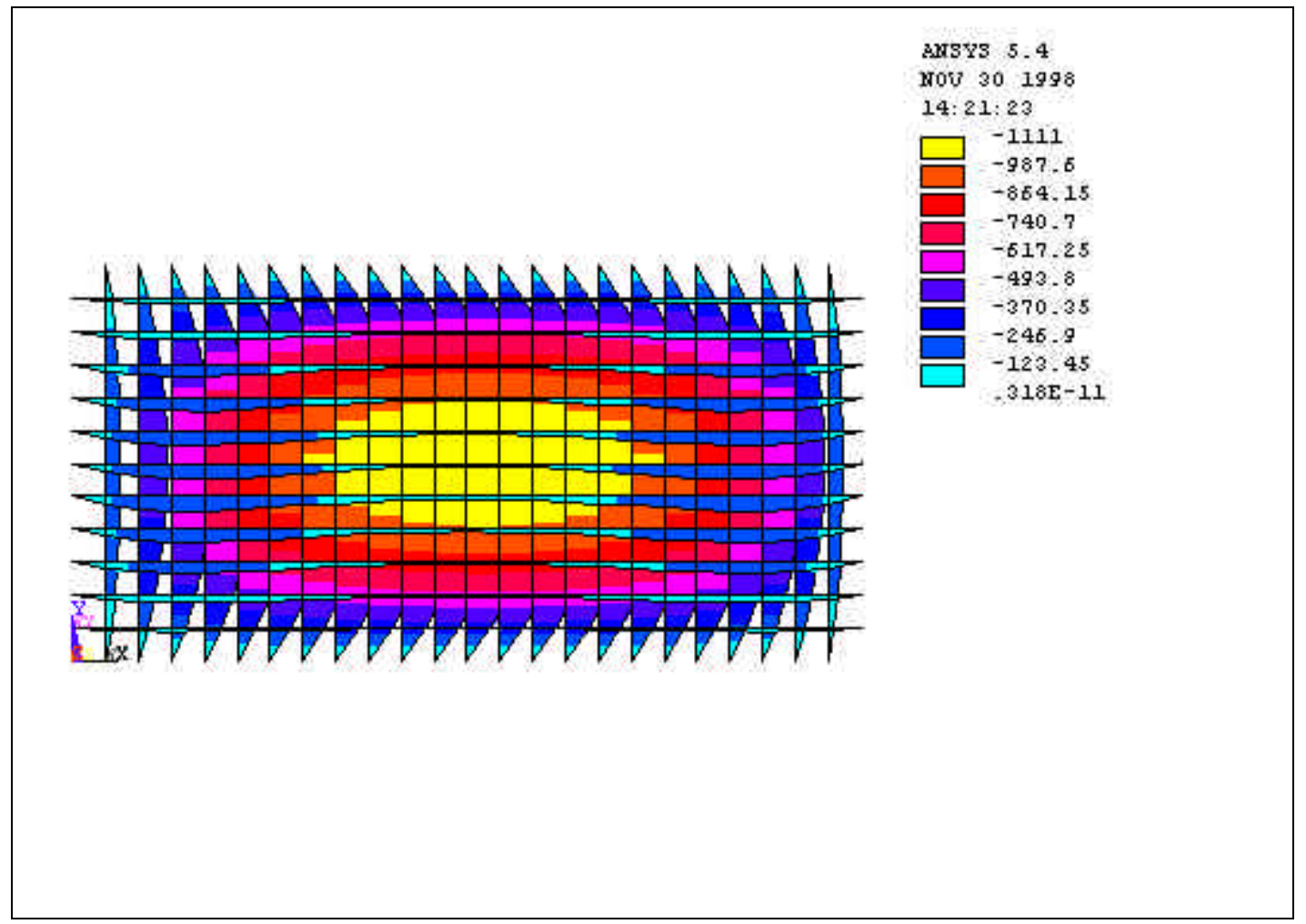

Fig.6.17 Diagrama de momento fletor- inércia à flexão transversal igual a $50 \%$ da inércia à flexão longitudinal

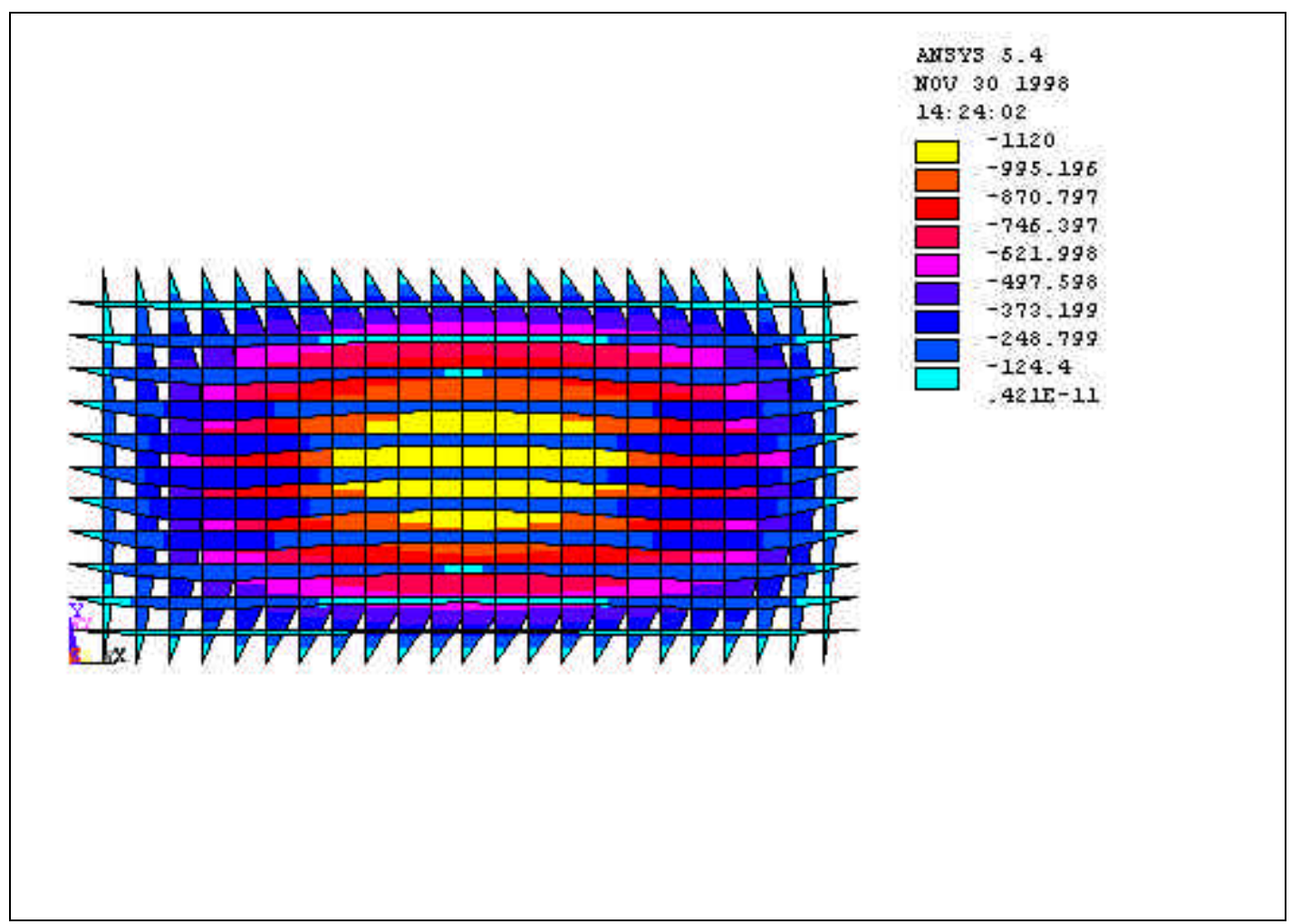

Fig.6.18 Diagrama de momento fletor- inércia à flexão transversal igual a $100 \%$ da inércia à flexão longitudinal 
Na seqüência de estudo do modelo de grelha isolada, apresenta-se a análise não-linear para a laje pré-moldada $(\mathrm{h}=12$ e $20 \mathrm{~cm})$, com dimensões em planta iguais a $(6,0 \mathrm{~m} \times 6,0 \mathrm{~m})$ e $(12,0 \mathrm{~m} \times 6,0 \mathrm{~m})$, sendo considerados os seguintes arranjos:

- Laje unidirecional;

- Laje unidirecional com nervuras transversais, chamadas de "nervuras de travamento";

- Laje bidirecional.

As dimensões das nervuras longitudinal e transversal são as apresentadas nas figuras 6.1 e 6.2 , respectivamente.

Nas lajes unidirecionais, ocorre a colaboração da capa de concreto na direção transversal (fig.6.19). Na análise não linear, como descrito em 3.5.2, as barras da grelha transversal que representam a capa de concreto também têm a sua rigidez (à flexão e à torção) reduzida a partir do início de fissuração. Em função da geometria e da resistência à tração do concreto determina-se o momento de fissuração $\left(M_{r}\right)$, sendo igual a 44,0 kN.cm.

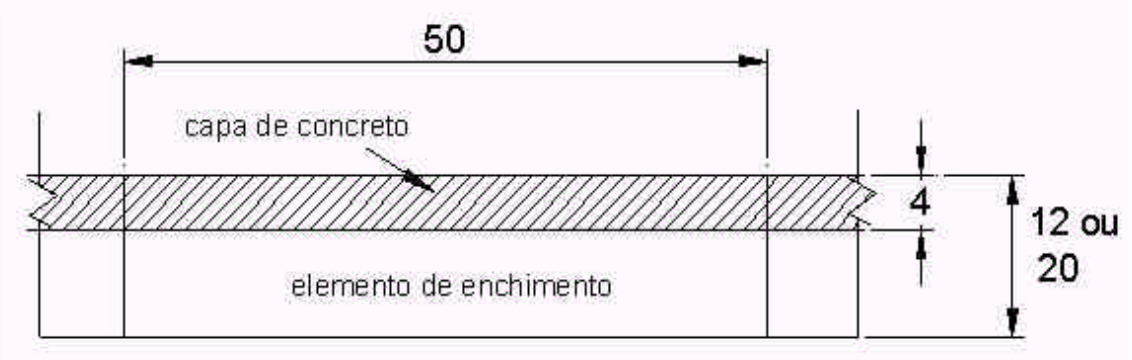

Fig.6.19 Contribuição da capa de concreto na direção transversal

Para as lajes unidirecionais com nervuras transversais, adotam-se 2 nervuras. As localizações destas nervuras transversais são vistas na figura 6.20 
$6,0 \mathrm{~m} \times 6,0 \mathrm{~m}$

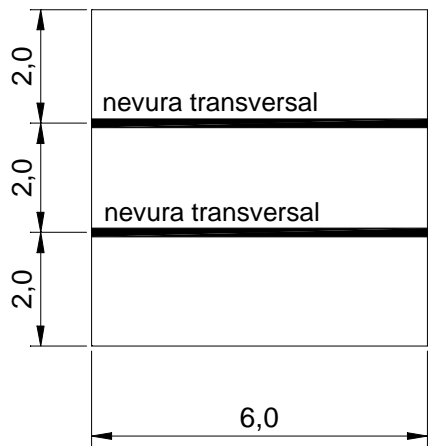

$12,0 \mathrm{~m} \times 6,0 \mathrm{~m}$

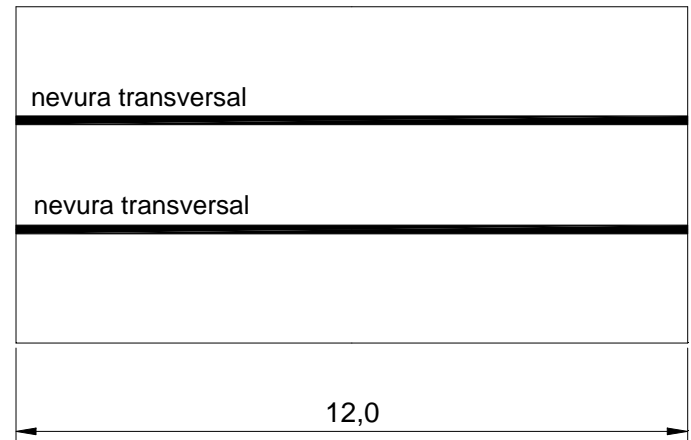

Fig.6.20 Nervuras transversais "nervura de travamento" da laje unidirecional

Como foi visto no início desta análise, a rigidez à flexão das nervuras influenciam na determinação dos momentos fletores atuantes nos elementos da grelha e também vimos que em função da razão entre a rigidez à flexão longitudinal e transversal em uma grelha pode-se ter momentos maiores do que os obtidos como nervuras simplesmente apoiadas. Devido a isso, e também como é comumente realizado, considera-se para o dimensionamento o mesmo valor da armadura calculada como nervura simplesmente apoiada nas lajes unidirecionais e nas lajes unidirecionais com nervuras transversais.

Para a armadura da nervura transversal "nervura de travamento" das lajes unidirecionais, dimensiona-se em função do máximo momento fletor obtido através de análise linear da grelha, considerando a rigidez a torção do estádio II. Os resultados são apresentados na tabela abaixo:

Tabela 6.7 Nervura transversal - momento fletor e dimensionamento

\begin{tabular}{|c|c|c|c|c|}
\hline laje $6 \mathrm{~m} \times 6 \mathrm{~m}$ & \multicolumn{2}{|c|}{ máx. momento fletor $(\mathrm{kN} . \mathrm{cm})$} & \multicolumn{2}{|c|}{ área de aço $(\mathrm{cm} 2)$} \\
\hline altura $(\mathrm{cm})$ & $\mathrm{h}=12$ & $\mathrm{~h}=20$ & $\mathrm{~h}=12$ & $\mathrm{~h}=20$ \\
\hline nervura transversal & 574 & 705 & 1,57 & 1,05 \\
\hline \hline laje $12 \mathrm{~m} \times 6 \mathrm{~m}$ & máx. momento fletor $(\mathrm{kN} . \mathrm{cm})$ & \multicolumn{2}{|c|}{ área de aço $(\mathrm{cm} 2)$} \\
\hline altura $(\mathrm{cm})$ & $\mathrm{h}=12$ & $\mathrm{~h}=20$ & $\mathrm{~h}=12$ & $\mathrm{~h}=20$ \\
\hline nervura transversal & 417 & 530 & 1,12 & 0,78 \\
\hline
\end{tabular}


$\mathrm{Na}$ laje bidirecional, em função de análise linear da grelha, e considerando a rigidez a torção do estádio II, obtêm-se os valores máximos de momento fletor na tabela 6.8 .

Tabela 6.8 Máximo momento fletor e área de aço da laje bidirecional

\begin{tabular}{|c|c|c|c|c|}
\hline laje $6 \mathrm{~m} \times 6 \mathrm{~m}$ & \multicolumn{2}{|c|}{ máx. momento fletor $(\mathrm{kN} . \mathrm{cm})$} & \multicolumn{2}{|c|}{ área de aço $(\mathrm{cm} 2)$} \\
\hline altura $(\mathrm{cm})$ & $\mathrm{h}=12$ & $\mathrm{~h}=20$ & $\mathrm{~h}=12$ & $\mathrm{~h}=20$ \\
\hline nervura longitudinal & 754 & 814 & 2,11 & 1,21 \\
\hline nervura transversal & 365 & 529 & 1,23 & 0,88 \\
\hline \hline laje $12 \mathrm{~m} \times 6 \mathrm{~m}$ & $\mathrm{máx}$. momento fletor $(\mathrm{kN} . \mathrm{cm})$ & \multicolumn{2}{|c|}{ área de aço (cm2) } \\
\hline altura $(\mathrm{cm})$ & $\mathrm{h}=12$ & $\mathrm{~h}=20$ & $\mathrm{~h}=12$ & $\mathrm{~h}=20$ \\
\hline nervura longitudinal & 1055 & 1255 & 3,09 & 1,9 \\
\hline nervura transversal & 211 & 286 & 0,69 & 0,47 \\
\hline
\end{tabular}

Apresenta-se na tabela 6.9, apenas para comparações, os valores de momento fletor calculados para a laje bidirecional, segundo as tabelas de BARES (1972). Os valores de momento nestas tabelas são função da relação entre os vãos, da condição de apoio dos bordos da laje (apoiado, engastado ou livre) e do valor do carregamento distribuído. Nesta tabela pode-se notar as grandes diferenças de valores de momento fletor entre 0 modelo de grelha e as tabelas de BARES.

Tabela 6.9 Momento fletor calculado segundo BARES, e comparação com valores obtidos pela grelha bidirecional.

\begin{tabular}{|c|c|c|c|c|c|c|}
\hline \multirow{3}{*}{$\begin{array}{c}\text { laje } \\
6 \mathrm{~m} \times 6 \mathrm{~m} \\
\text { altura }(\mathrm{cm})\end{array}$} & \multicolumn{4}{|c|}{ máx. momento fletor (kN.cm) } & \multirow{2}{*}{\multicolumn{2}{|c|}{ diferença \% }} \\
\hline & \multicolumn{2}{|c|}{ BARES } & \multicolumn{2}{|c|}{ Grelha } & & \\
\hline & $h=12$ & $\mathrm{~h}=20$ & $h=12$ & $h=20$ & $\mathrm{~h}=12$ & $\mathrm{~h}=20$ \\
\hline nervura longitudinal & 640 & 752 & 754 & 814 & 15,1 & 7,6 \\
\hline nervura transversal & 640 & 752 & 365 & 529 & 43,0 & 29,7 \\
\hline laje & \multicolumn{4}{|c|}{ máx. momento fletor (kN.cm) } & \multirow{2}{*}{\multicolumn{2}{|c|}{ diferença \% }} \\
\hline $12 \mathrm{~m} \times 6 \mathrm{~m}$ & \multicolumn{2}{|c|}{ BARES } & \multicolumn{2}{|c|}{ Grelha } & & \\
\hline altura (cm) & $h=12$ & $h=20$ & $h=12$ & $h=20$ & $\mathrm{~h}=12$ & $\mathrm{~h}=20$ \\
\hline nervura longitudinal & 1498 & 1762 & 1055 & 1255 & 29,6 & 28,8 \\
\hline nervura transversal & 478 & 704 & 211 & 286 & 55,9 & 59,4 \\
\hline
\end{tabular}


Considera-se o carregamento nos nós da grelha, em função da área de influência em 21 incrementos de carga. Sendo o incremento 15 referente à atuação de todo o carregamento e o incremento $21 \mathrm{com}$ a atuação do carregamento de cálculo, ou seja, o valor de peso próprio + sobrecarga multiplicado pelo coeficiente de majoração das cargas igual a 1,4.

Apresenta-se nas tabelas 6.10 e $\mathbf{6 . 1 1}$ os valores de momento fletor utilizados para o dimensionamento das nervuras e os valores de momento fletor obtidos através da análise não-linear.

Tabela 6.10 Momento fletor utilizado para o dimensionamento e o obtido pela análise não linear - nervura longitudinal $-\mathrm{h}=12 \mathrm{~cm}$.

\begin{tabular}{|c|c|c|c|c|c|c|}
\hline \multirow{3}{*}{$\begin{array}{c}\text { modelos } \\
\text { de laje } \\
\text { pré-moldada }\end{array}$} & \multicolumn{2}{|c|}{ grelha $6 \mathrm{~m} \times 6 \mathrm{~m}$} & \multirow{3}{*}{$\begin{array}{c}\text { diferença } \\
\%\end{array}$} & \multicolumn{2}{|c|}{ grelha $12 \mathrm{~m} \times 6 \mathrm{~m}$} & \multirow{3}{*}{$\begin{array}{c}\text { diferença } \\
\%\end{array}$} \\
\hline & \multicolumn{2}{|c|}{ momento fletor kN.cm } & & \multicolumn{2}{|c|}{ momento fletor kN.cm } & \\
\hline & dimensionamento & análise não-linear & & dimensionamento & análise não-linear & \\
\hline unidirecional & 891 & 815 & 8,5 & 891 & 913 & 2,5 \\
\hline unidir.c/ nerv. transv. & 891 & 742 & 16,7 & 891 & 940 & 5,5 \\
\hline bidirecional & 754 & 669 & 11,3 & 1055 & 972 & 7,9 \\
\hline
\end{tabular}

Tabela 6.11 Momento fletor utilizado para o dimensionamento e o obtido pela análise não linear - nervura longitudinal - laje $\mathrm{h}=20 \mathrm{~cm}$.

\begin{tabular}{|c|c|c|c|c|c|c|}
\hline \multirow{3}{*}{$\begin{array}{c}\text { modelos } \\
\text { de laje } \\
\text { pré-moldada }\end{array}$} & \multicolumn{2}{|c|}{ grelha $6 \mathrm{~m} \times 6 \mathrm{~m}$} & \multirow{3}{*}{$\begin{array}{c}\text { diferença } \\
\%\end{array}$} & \multicolumn{2}{|c|}{ grelha $12 \mathrm{~m} \times 6 \mathrm{~m}$} & \multirow{3}{*}{$\begin{array}{c}\text { diferença } \\
\%\end{array}$} \\
\hline & \multicolumn{2}{|c|}{ momento fletor kN.cm } & & \multicolumn{2}{|c|}{ momento fletor kN.cm } & \\
\hline & dimensionamento & análise não-linear & & dimensionamento & análise não-linear & \\
\hline unidirecional & 985 & 958 & 2,7 & 985 & 996 & 1,1 \\
\hline unidir.c/ nerv. transv. & 985 & 861 & 12,6 & 985 & 1048 & 6,4 \\
\hline bidirecional & 814 & 668 & 17,9 & 1255 & 1118 & 10,9 \\
\hline
\end{tabular}

Nas figuras 6.21 e 6.22 mostram-se as variações do máximo momento fletor em função do carregamento, para as lajes unidirecionais e bidirecionais.

Os diagramas de carga $\mathrm{x}$ deslocamentos, para as lajes $\mathrm{e}$ comparações com a nervura simplesmente apoiada, são vistos nas figuras 6.23 a 6.26 . 


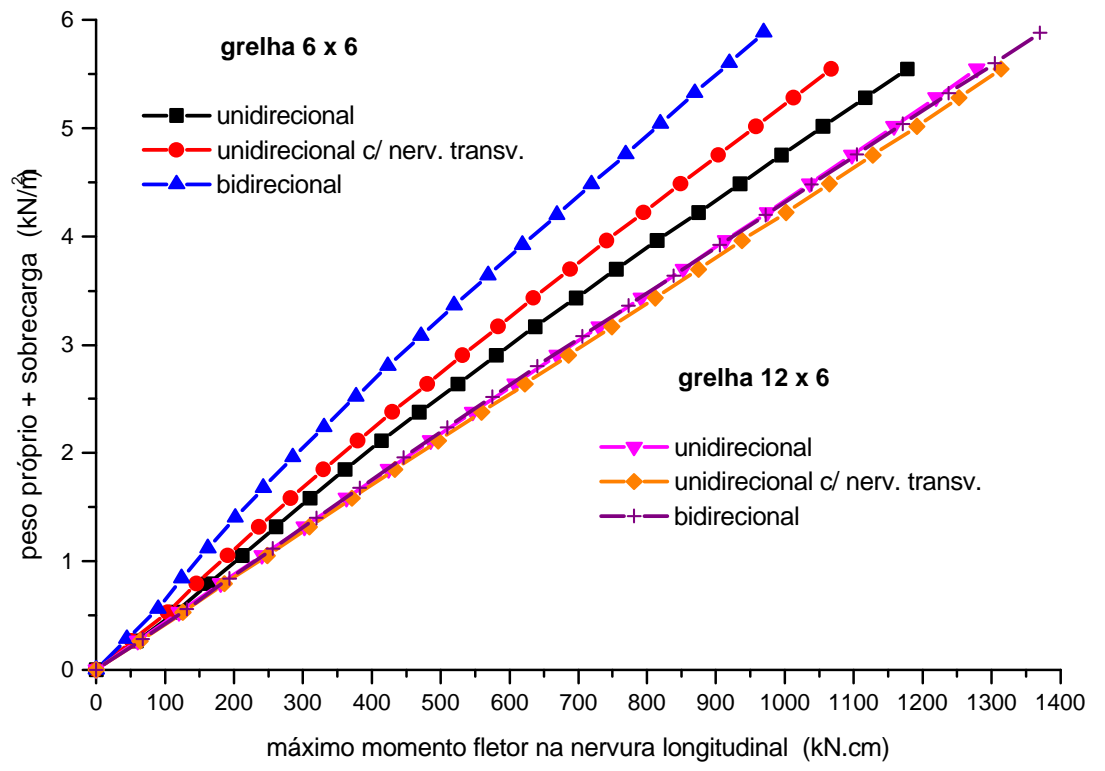

Fig.6.21 Carregamento x máximo momento fletor $-\mathrm{h}=12 \mathrm{~cm}$

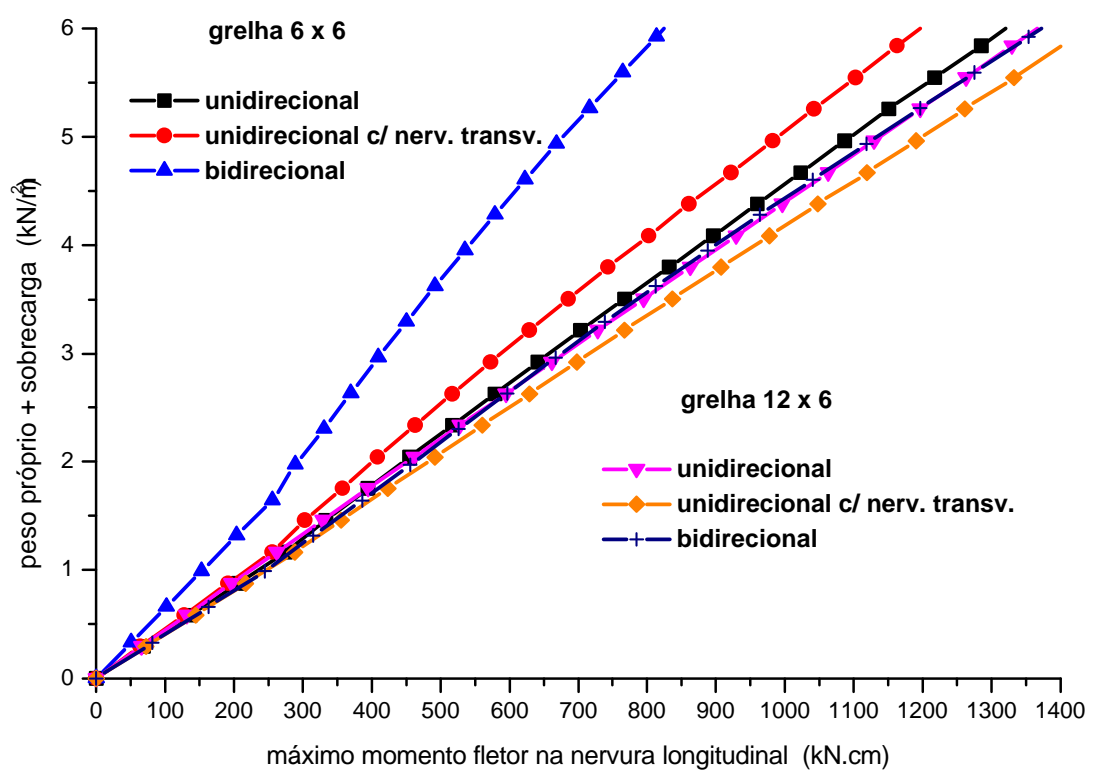

Fig. 6.22 Carregamento $x$ máximo momento fletor $-\mathrm{h}=20 \mathrm{~cm}$ 


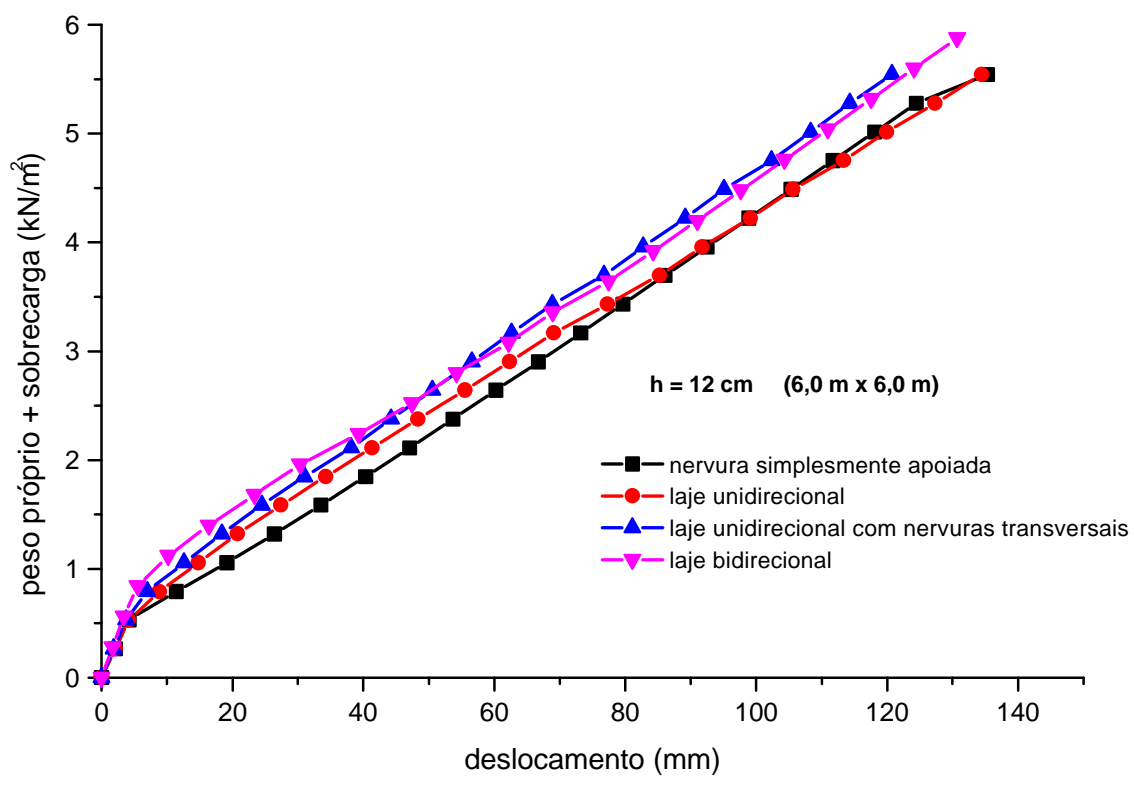

Fig.6.23 Carregamento $x$ deslocamento $-\mathrm{h}=12 \mathrm{~cm}(6,0 \mathrm{~m} \times 6,0 \mathrm{~m})$

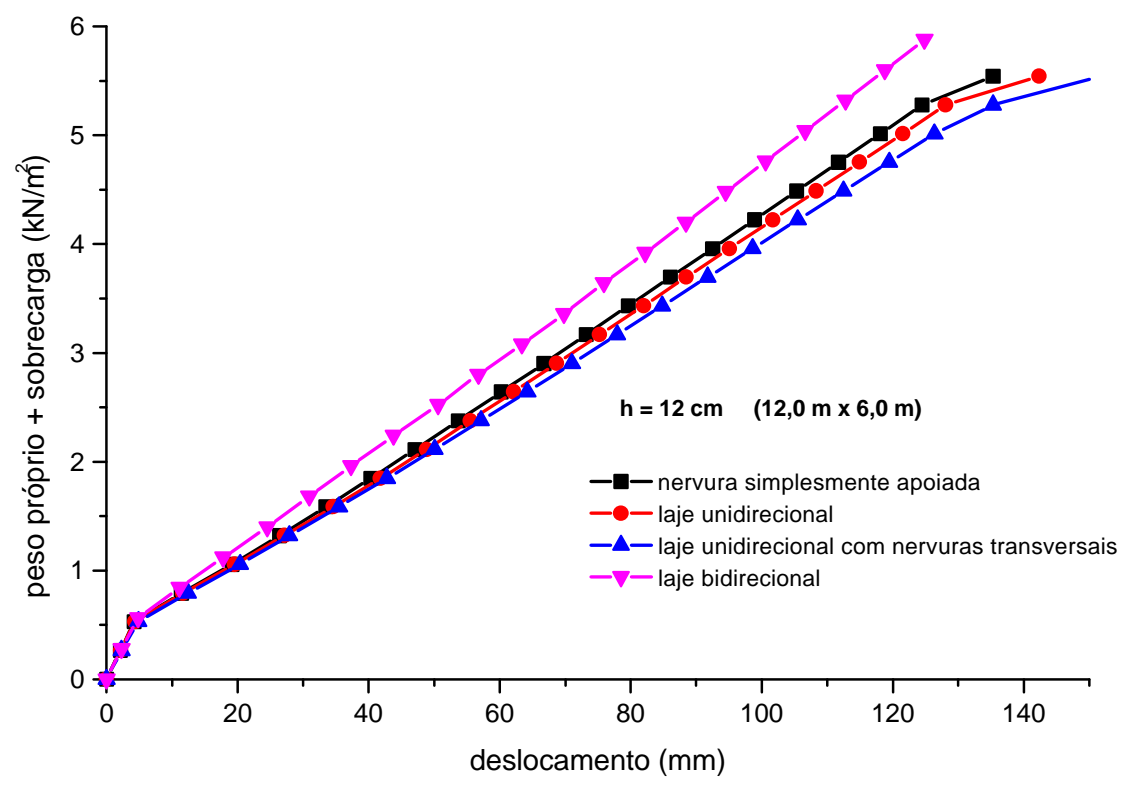

Fig.6.24 Carregamento $x$ deslocamento $-\mathrm{h}=12 \mathrm{~cm}(12,0 \mathrm{~m} \times 6,0 \mathrm{~m})$ 


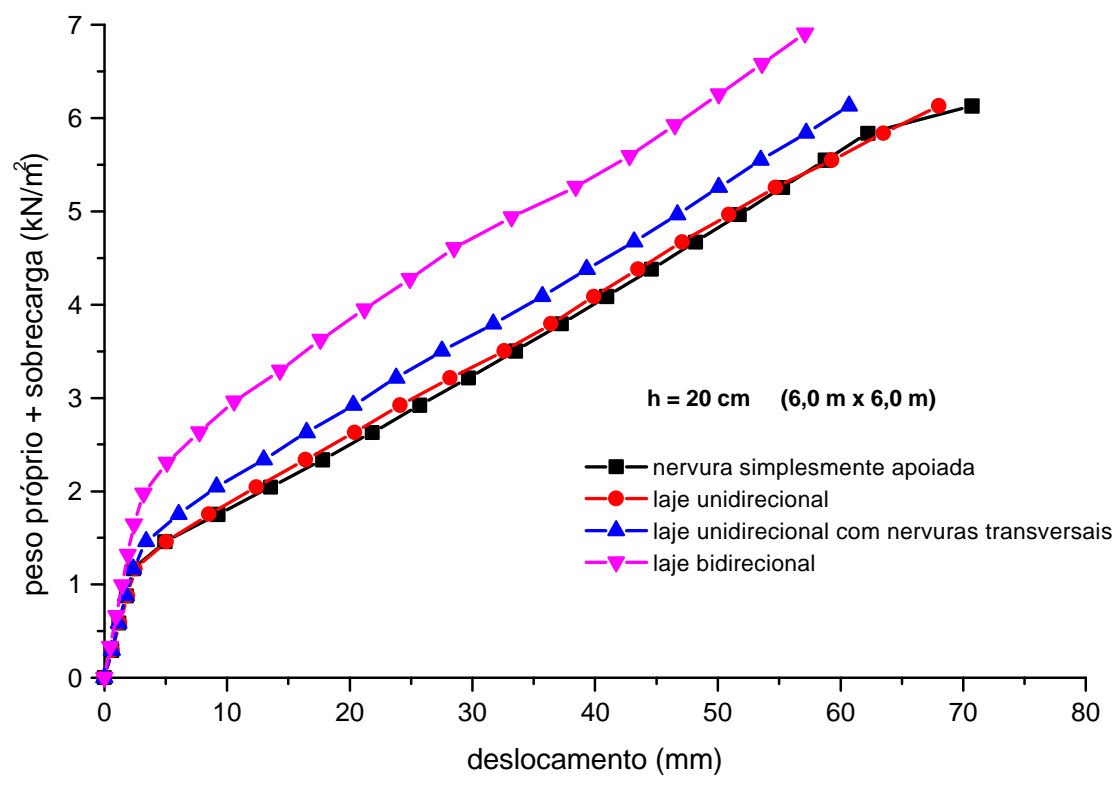

Fig.6.25 Carregamento $x$ deslocamento $-h=20 \mathrm{~cm} \quad(6,0 \mathrm{~m} \times 6,0 \mathrm{~m})$

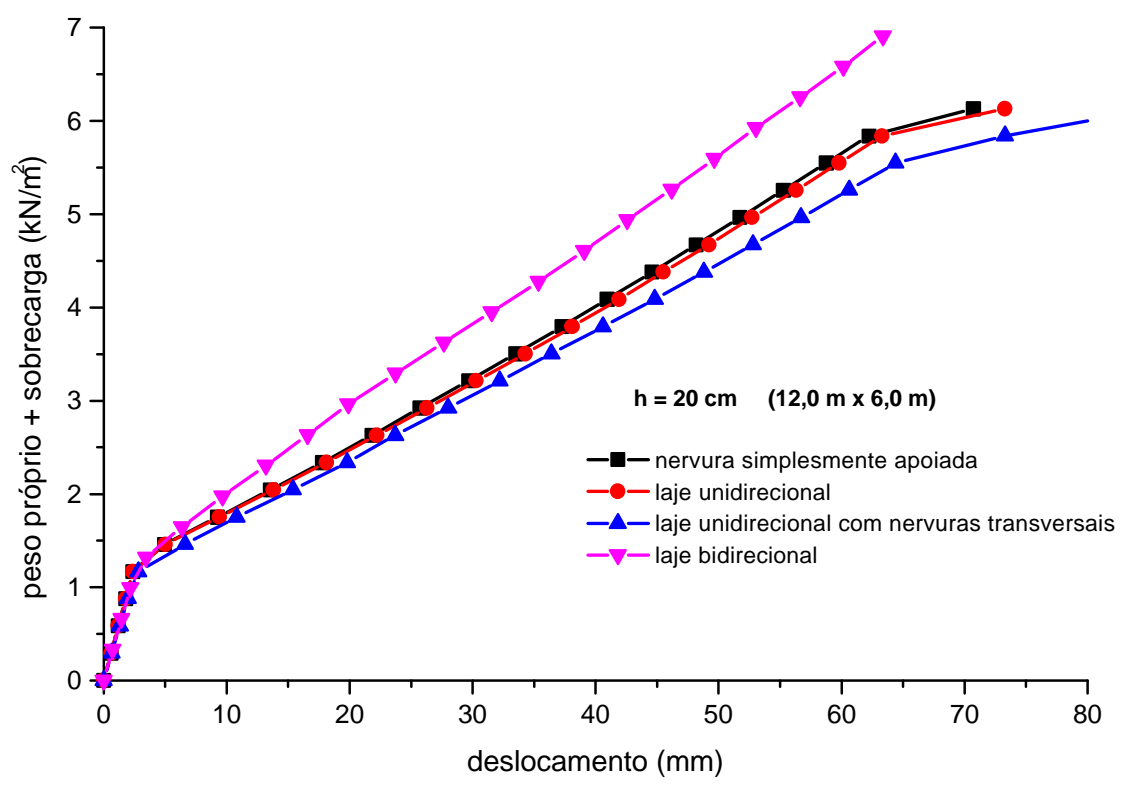

Fig.6.26 Carregamento $x$ deslocamento $-h=20 \mathrm{~cm}(12,0 \mathrm{~m} \times 6,0 \mathrm{~m})$ 
A reação de apoio destas lajes depende do tipo de laje (unidirecional, bidirecional) e também do formato em planta (quadrado, retangular). Usualmente nestas lajes, além dos valores de sobrecarga distribuído pela área da laje, têm-se também cargas linearmente distribuídas (alvenaria) sendo que o mais indicado é calcular a reação de apoio e também outros parâmetros (momento fletor, deslocamentos) utilizando-se um programa feito para computador que faça análises mediante grelha ou elementos finitos.

Apresentam-se a seguir, na tabela 6.12, os valores médios da parcela do carregamento total que é a reação de apoio das nervuras longitudinais, ou seja, das nervuras que contêm a vigota pré-moldada. Estes valores foram obtidos através das análises linear e não-linear, com altura igual a 12 e a 20 $\mathrm{cm}$ e decorrentes apenas de carregamentos distribuídos por área.

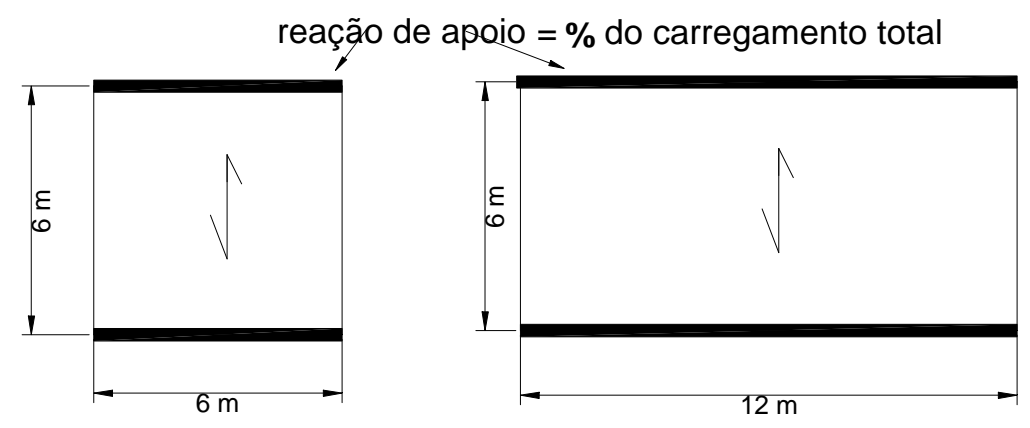

Fig.6.27 Reação de apoio das nervuras longitudinais $(6 \mathrm{~m} \times 6 \mathrm{~m}$ e $12 \mathrm{~m} \times 6 \mathrm{~m})$

Tabela 6.12 Reação de apoio das nervuras longitudinais - Parcela (\%) do carregamento total.

\begin{tabular}{|c|c|c|c|c|}
\hline \multicolumn{5}{|c|}{ reação de apoio das nervuras longitudinais - \% do carregamento total } \\
\hline \multirow{3}{*}{$\begin{array}{l}\text { modelos } \\
\text { de laje } \\
\text { pré-moldada }\end{array}$} & \multicolumn{2}{|c|}{ grelha $6 \mathrm{~m} \times 6 \mathrm{~m}$} & \multicolumn{2}{|c|}{ grelha $12 \mathrm{~m} \times 6 \mathrm{~m}$} \\
\hline & \multicolumn{2}{|c|}{ altura da laje } & \multicolumn{2}{|c|}{ altura da laje } \\
\hline & $\mathrm{h}=12 \mathrm{~cm}$ & $\mathrm{~h}=20 \mathrm{~cm}$ & $\mathrm{~h}=12 \mathrm{~cm}$ & $\mathrm{~h}=20 \mathrm{~cm}$ \\
\hline unidirecional & 83 & $\overline{90}$ & 85 & 91 \\
\hline unidir.c/ nerv. transv. & 73 & 76 & 80 & 82 \\
\hline bidirecional & 60 & 55 & 74 & 73 \\
\hline
\end{tabular}




\subsubsection{GRELHA ISOLADA COM A CONSIDERAÇÃO DAS VIGAS DE EXTREMIDADE}

Para analisar o grau de influência da rigidez à torção das vigas de extremidade nas lajes pré-moldadas considera-se, neste item, as vigas com dimensões $0,15 \mathrm{~m} \times 0,60 \mathrm{~m}$. É mostrada na figura 6.28 a grelha a ser utilizada nos arranjos seguintes.

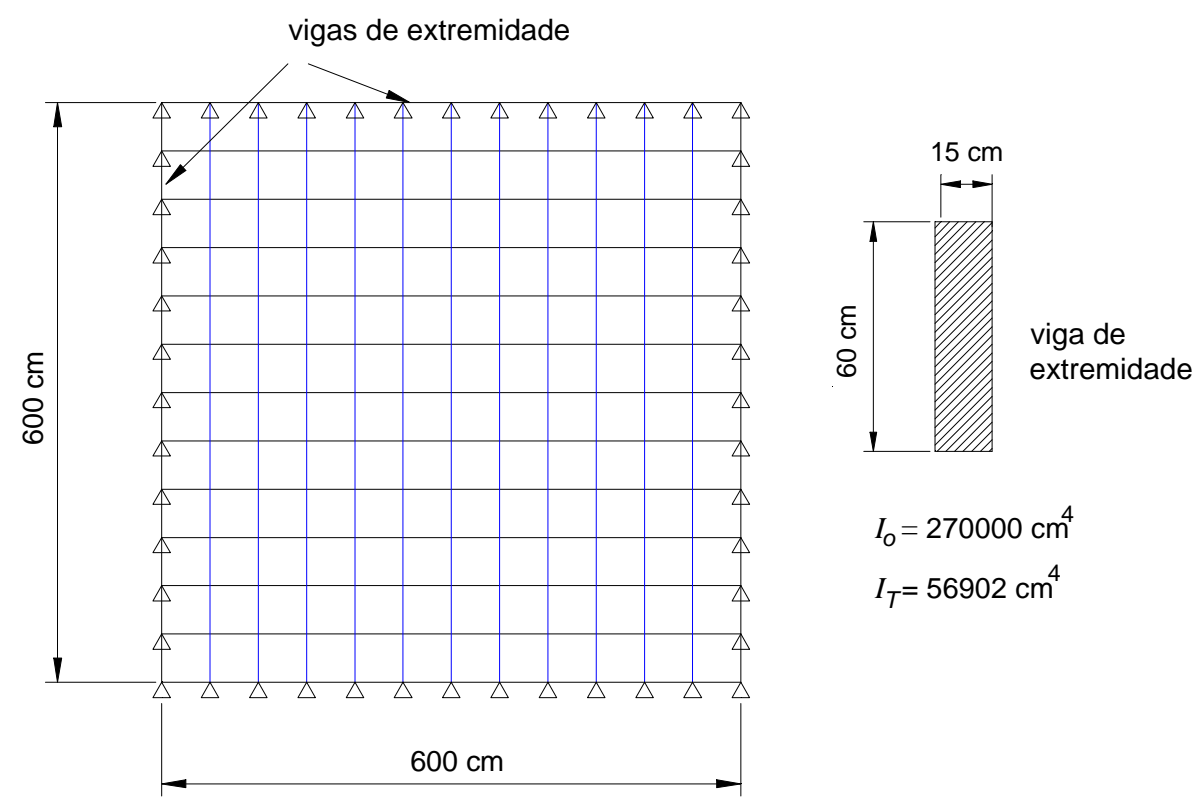

Fig.6.28 Grelha com vigas de extremidade

Os arranjos com a consideração das vigas de extremidade são:

- Laje pré-moldada unidirecional ( $h=12$ e $20 \mathrm{~cm}$ );

- Laje pré-moldada bidirecional ( $\mathrm{h}=12$ e $20 \mathrm{~cm}$ ).

Como visto na figura $\mathbf{6 . 2 8}$, consideram-se as vigas com deslocamentos impedidos, deste modo analisa-se somente a influência da rigidez à torção das vigas. A influência da deformação das vigas é vista na análise de grelhas contínuas. 
Mediante a análise elástico-linear, determinam-se os valores do máximo momento fletor negativo para as nervuras da laje e das vigas de extremidade.

Para verificar a influência da rigidez à torção nos valores de momento fletor, considera-se a rigidez à torção para o estádio $\mathrm{I}\left(0,3 . E_{C} \cdot I_{T}\right)$ e estádio II $\left(0,05 \cdot E_{c} \cdot I_{T}\right)$.

Tabela 6.13 Máximo momento fletor negativo nas nervuras da laje (kN.cm)

\begin{tabular}{|c|c|c|c|c|c|c|}
\hline \multirow{2}{*}{$\begin{array}{c}\text { rigidez à } \\
\text { à } \\
\text { Torção }\end{array}$} & \multicolumn{2}{|c|}{ laje unid. } & \multicolumn{4}{c|}{ laje bid. } \\
\cline { 2 - 7 } & \multicolumn{2}{|c|}{ nerv. long. } & \multicolumn{2}{|c|}{ nerv. long. } & \multicolumn{2}{|c|}{ nerv. transv. } \\
\cline { 2 - 7 } & estádio I & estádio II & estádio I & estádio II & estádio I & estádio II \\
\hline $\mathrm{h}=12 \mathrm{~cm}$ & 373 & 153 & 311 & 126 & 252 & 122 \\
\hline $\mathrm{h}=20 \mathrm{~cm}$ & 183 & 30 & 164 & 39 & 160 & 40 \\
\hline
\end{tabular}

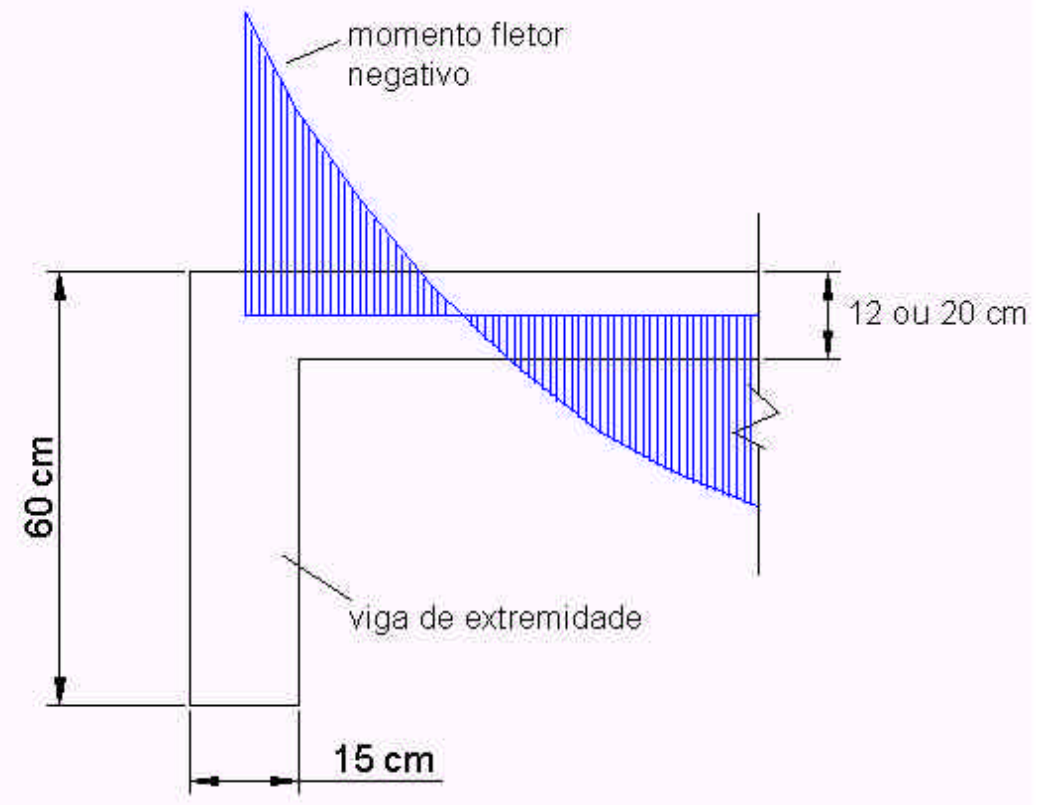

Fig.6.29 Momento fletor negativo

Pode-se notar na tabela 6.13 as diferenças de valores de momento fletor negativo nas nervuras, em função da rigidez à torção adotada.

Em função da altura da laje também ocorrem diferenças, há um maior engastamento das nervuras com $12 \mathrm{~cm}$ de altura nas vigas de extremidade do que para as nervuras $\mathrm{com} 20 \mathrm{~cm}$ de altura. $\mathrm{O}$ valor do momento fletor 
negativo na nervura com $12 \mathrm{~cm}$ de altura é superior a nervura com altura igual a $20 \mathrm{~cm}$. Quanto maior for a rigidez relativa entre a viga de extremidade e a nervura, maior será o engastamento da nervura na viga, como pode ser visto na tabela 6.13.

Para a consideração da rigidez das vigas de extremidade é necessário dimensionar a laje ao momento fletor negativo, sendo que para o seu dimensionamento existe dúvidas no valor do momento fletor a ser considerado, pois é função direta da rigidez à torção dos elementos, que geralmente é considerada como um valor reduzido.

Nesta análise considera-se o maior momento fletor negativo obtido na análise linear e dimensionam-se nervuras.

Considera-se a mesma armadura nas seções das nervuras submetidas ao momento fletor positivo, ou seja, das lajes unidirecionais e bidirecionais vistas em 6.3.2. Para a região de momento fletor negativo, indica-se os valores obtidos pelo dimensionamento na tabela 6.14.

Tabela 6.14 Dimensionamento das nervuras submetidas ao momento fletor negativo

\begin{tabular}{|c|c|c|c|c|}
\hline altura $(\mathrm{cm})$ & \multicolumn{2}{|c|}{$\mathrm{h}=12 \mathrm{~cm}$} & \multicolumn{2}{c|}{$\mathrm{h}=20 \mathrm{~cm}$} \\
\hline dimensionamento & $\begin{array}{c}\text { momento negativo } \\
\mathrm{kN} . \mathrm{cm}\end{array}$ & $\begin{array}{c}\mathrm{As} \\
\mathrm{cm} 2\end{array}$ & $\begin{array}{c}\text { momento negativo } \\
\mathrm{kN} . \mathrm{cm}\end{array}$ & $\begin{array}{c}\text { As } \\
\mathrm{cm} 2\end{array}$ \\
\hline nervura longitudinal & 373 & $1,14 / 0,35^{*}$ & 183 & 0,27 \\
\hline nervura transversal & 252 & $0,97 / 0,35^{*}$ & 160 & 0,27 \\
\hline
\end{tabular}

* O dimensionamento da nervura resulta em armadura dupla: $A_{S} / A_{s 2}$

Quando houver a necessidade de armadura dupla na nervura submetida ao momento fletor negativo, esta armadura de compressão pode ser a mesma da obtida pelo dimensionamento ao momento fletor positivo, desde que satisfaçam as recomendações de ancoragem.

Nesta análise não-linear com vigas de extremidade considera-se a rigidez à torção destas vigas com valor constante ao longo do carregamento. 
Deste modo, adota-se, na primeira análise, a rigidez à torção do estádio I e na segunda, a rigidez à torção do estádio II. Com isso, obtêm-se duas curvas.

Os demais elementos da grelha (elementos longitudinais e transversais) mantêm o mesmo procedimento, ou seja, possuem rigidez à flexão e à torção variáveis em função do momento fletor atuante.

Nas figuras 6.30 e 6.31, mostra-se, para as lajes unidirecionais, a variação do máximo momento fletor negativo ao longo do carregamento em função da rigidez à torção das vigas de extremidade.

Apresenta-se a seguir nas figuras 6.32 a 6.35 os valores de deslocamento em função do carregamento, obtidos através da análise nãolinear para os modelos de grelha com vigas de extremidade e comparações com os valores obtidos sem a consideração das vigas de extremidade.

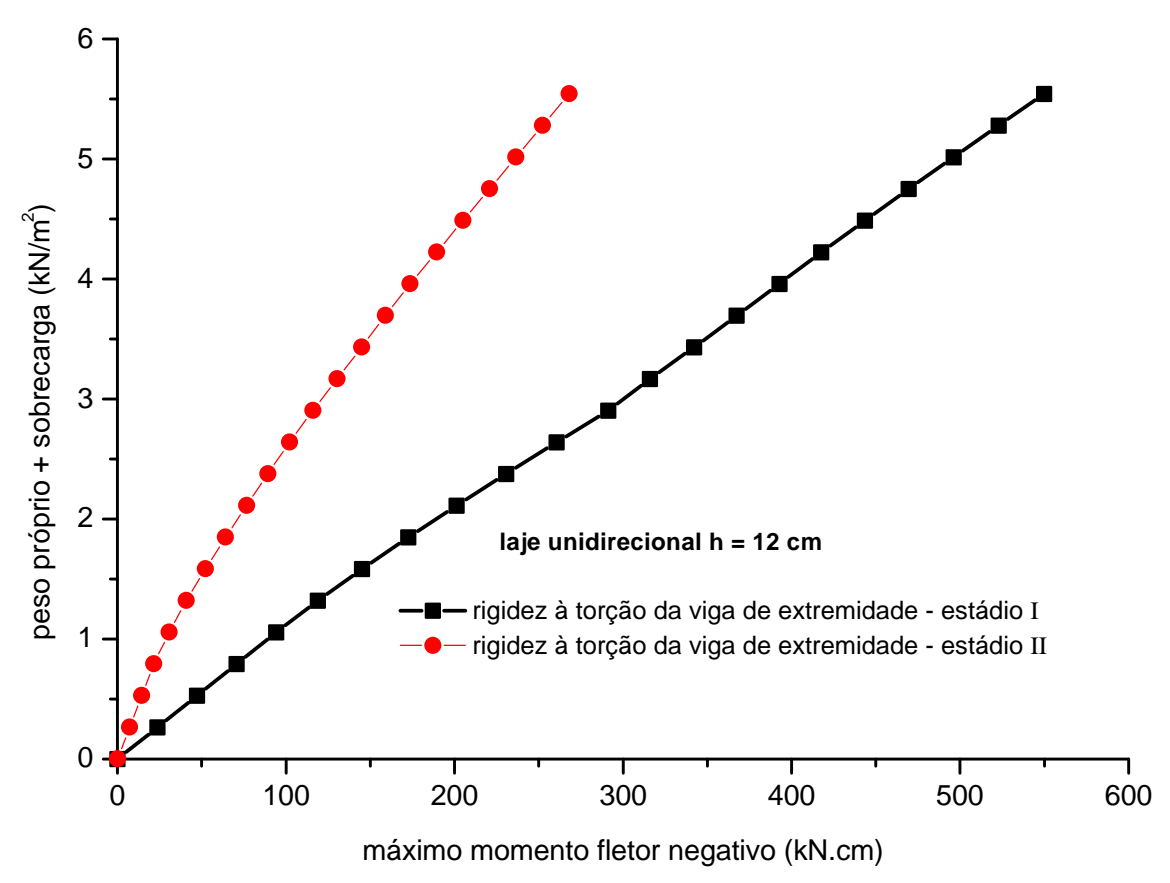

Fig.6.30 Carregamento x máximo momento fletor negativo laje unidirecional $-\mathrm{h}=12 \mathrm{~cm}$ 


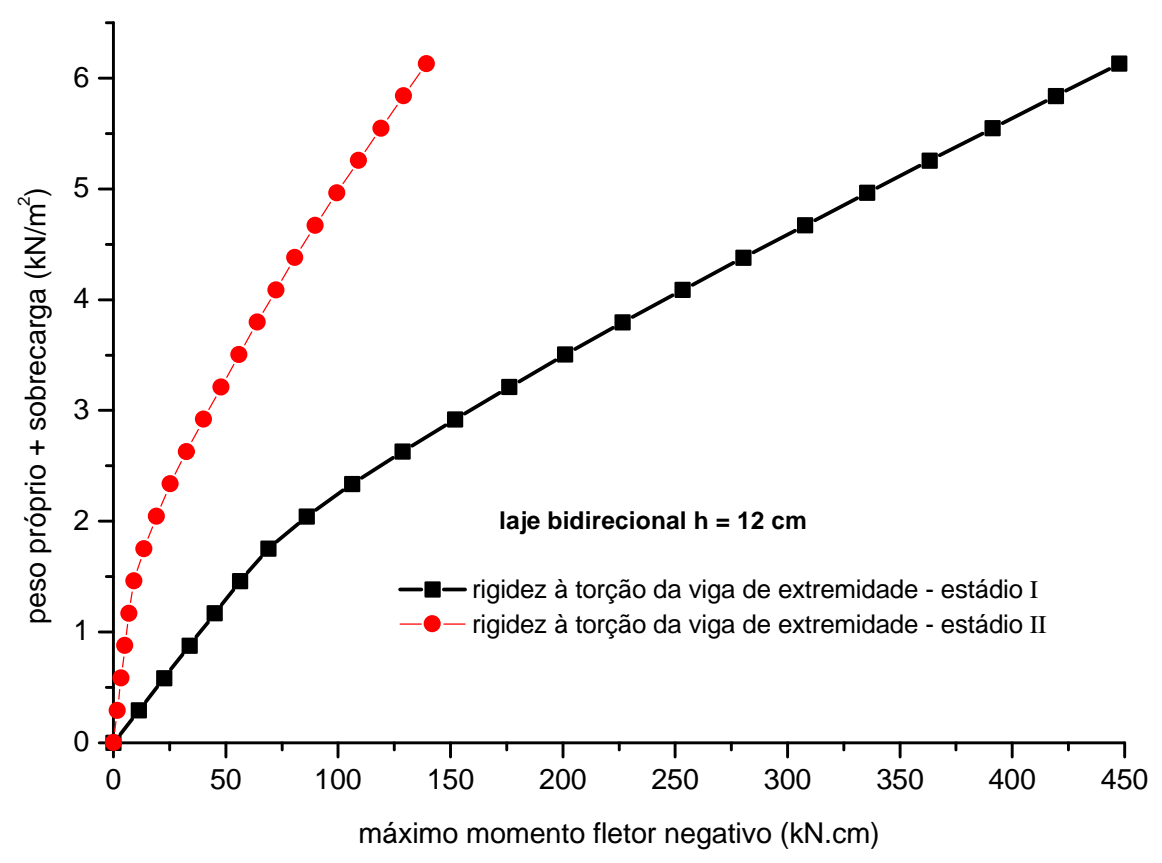

Fig.6.31 Carregamento x máximo momento fletor negativo laje unidirecional $-\mathrm{h}=20 \mathrm{~cm}$

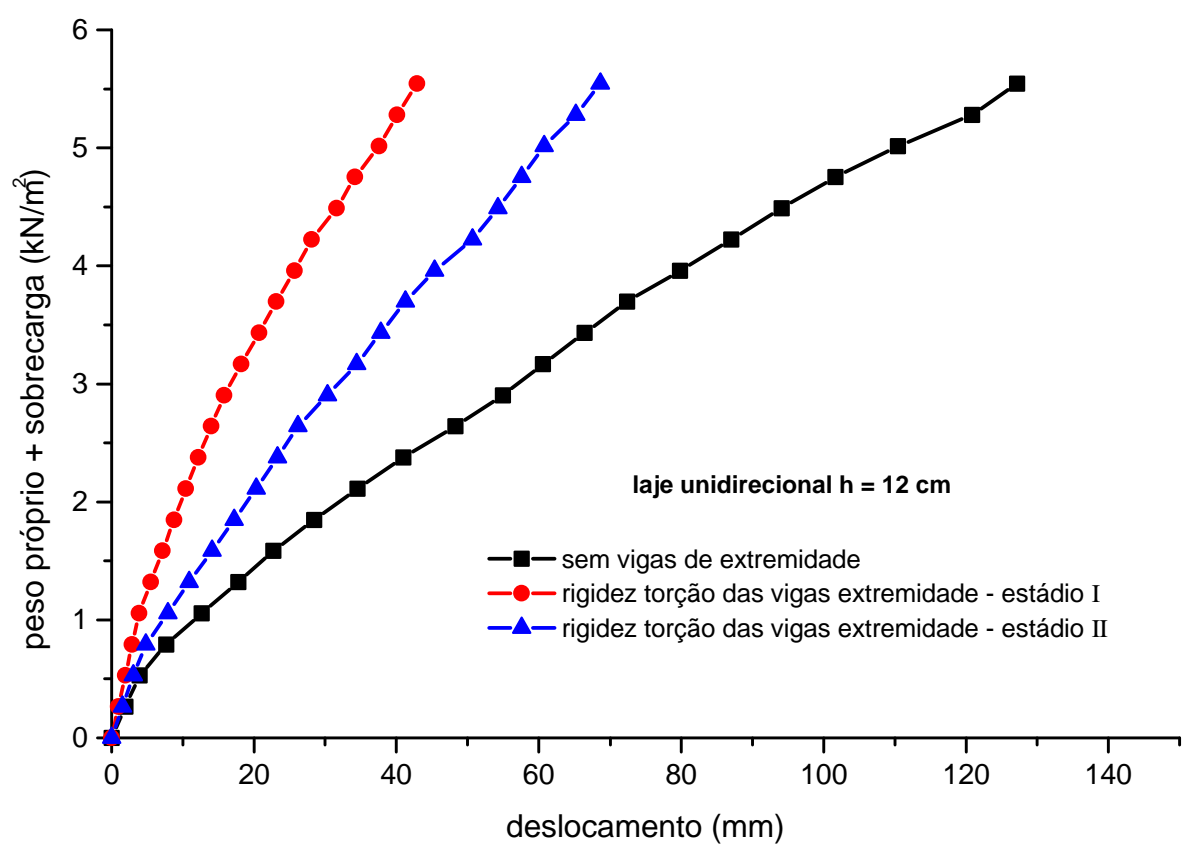

Fig.6.32 Carregamento $x$ deslocamento laje unidirecional $-\mathrm{h}=12 \mathrm{~cm}$ 


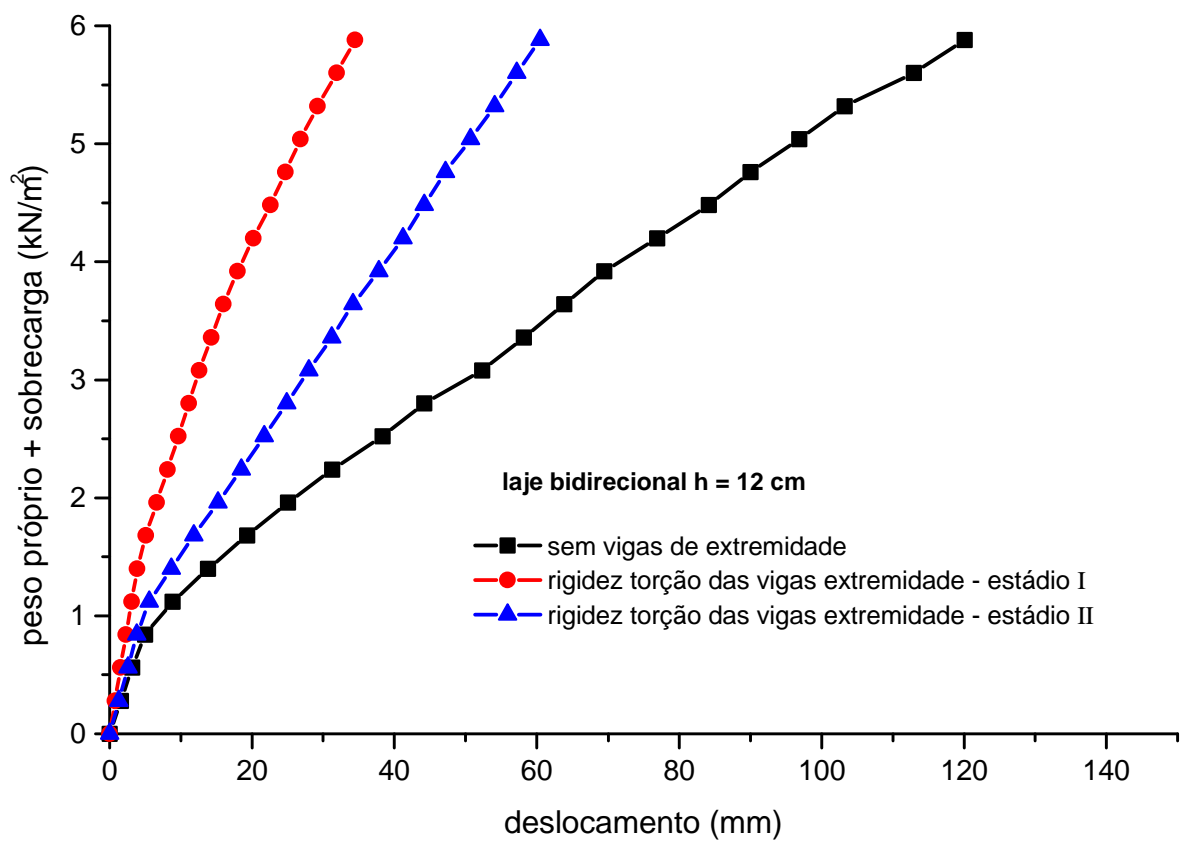

Fig.6.33 Carregamento $x$ deslocamento

laje bidirecional $-\mathrm{h}=12 \mathrm{~cm}$

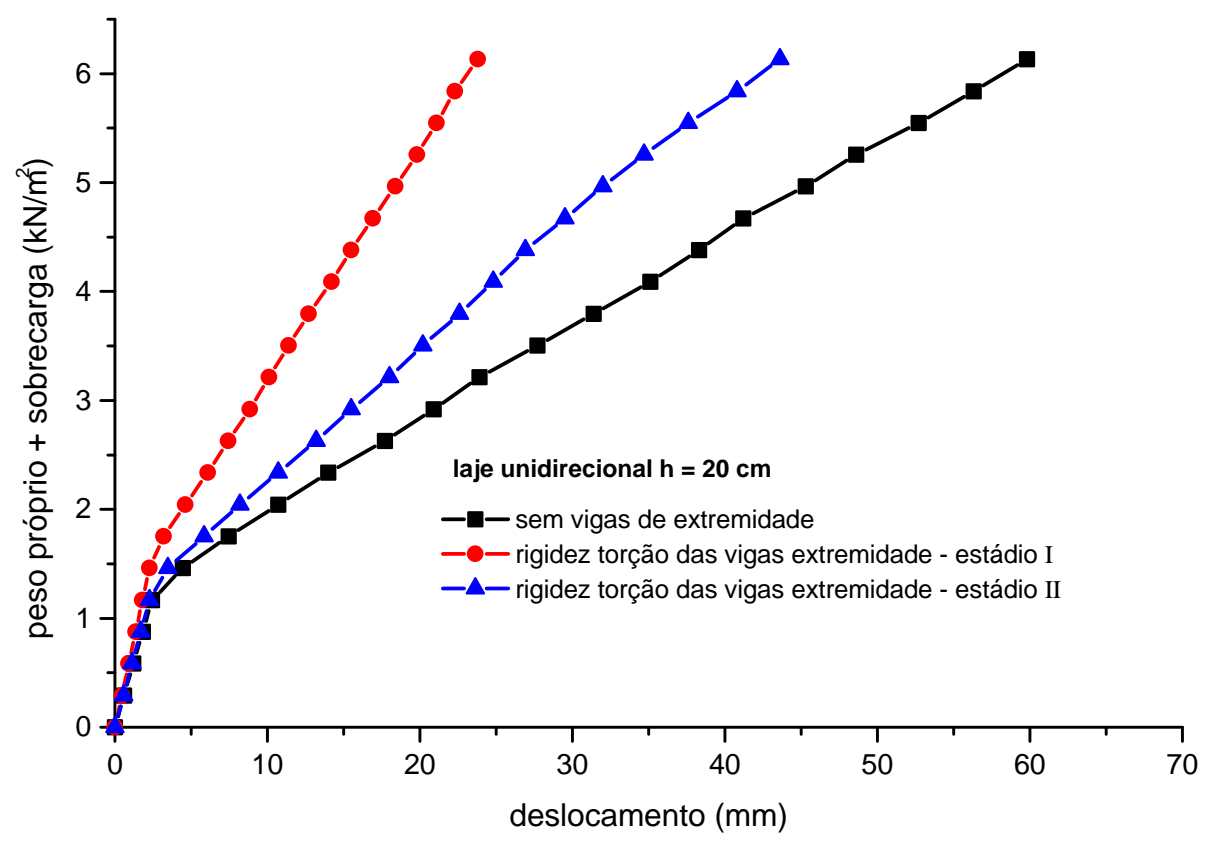

Fig.6.34 Carregamento $x$ deslocamento laje unidirecional $-\mathrm{h}=20 \mathrm{~cm}$ 


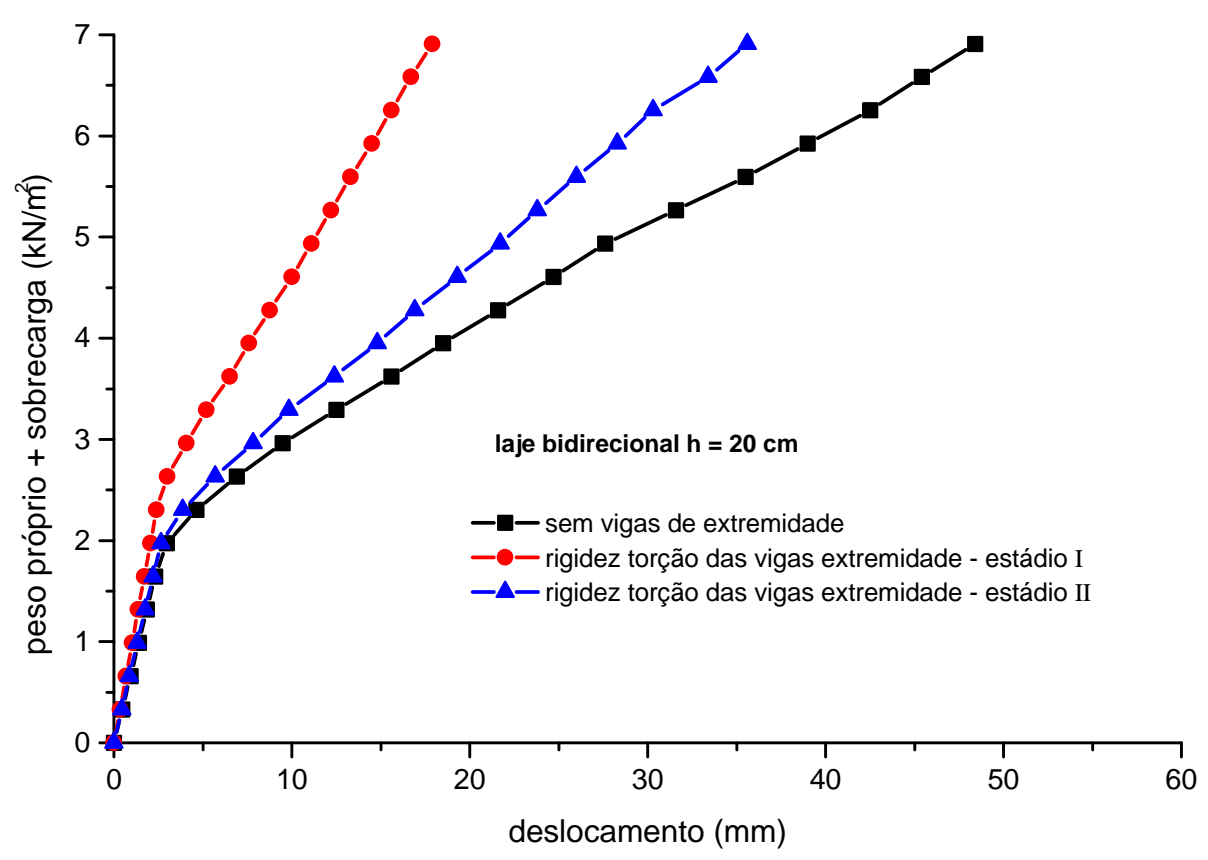

Fig.6.35 Carregamento $x$ deslocamento laje bidirecional $-\mathrm{h}=20 \mathrm{~cm}$

\subsubsection{GRELHA CONTÍNUA}

Como visto na análise das vigas isoladas e contínuas, o parâmetro principal é a rigidez à flexão dos elementos. Para a análise das grelhas, além da influência da rigidez à flexão há também a influência da rigidez à torção dos elementos constituintes da grelha (nervuras, vigas de extremidade).

Para a modelagem da grelha contínua, existem muitas variáveis envolvidas, sendo que a principal é continuidade entre as nervuras, sendo esta função da capacidade da estrutura absorver momentos fletores negativos na "ligação" entre lajes adjacentes.

Nesta análise, portanto, verifica-se a continuidade entre lajes através do modelo de grelha para as lajes unidirecionais com altura igual a 12 e a 
20 cm. Verifica-se, também, a influência da consideração ou não da deformabilidade da viga central de apoio das lajes (fig.6.36).

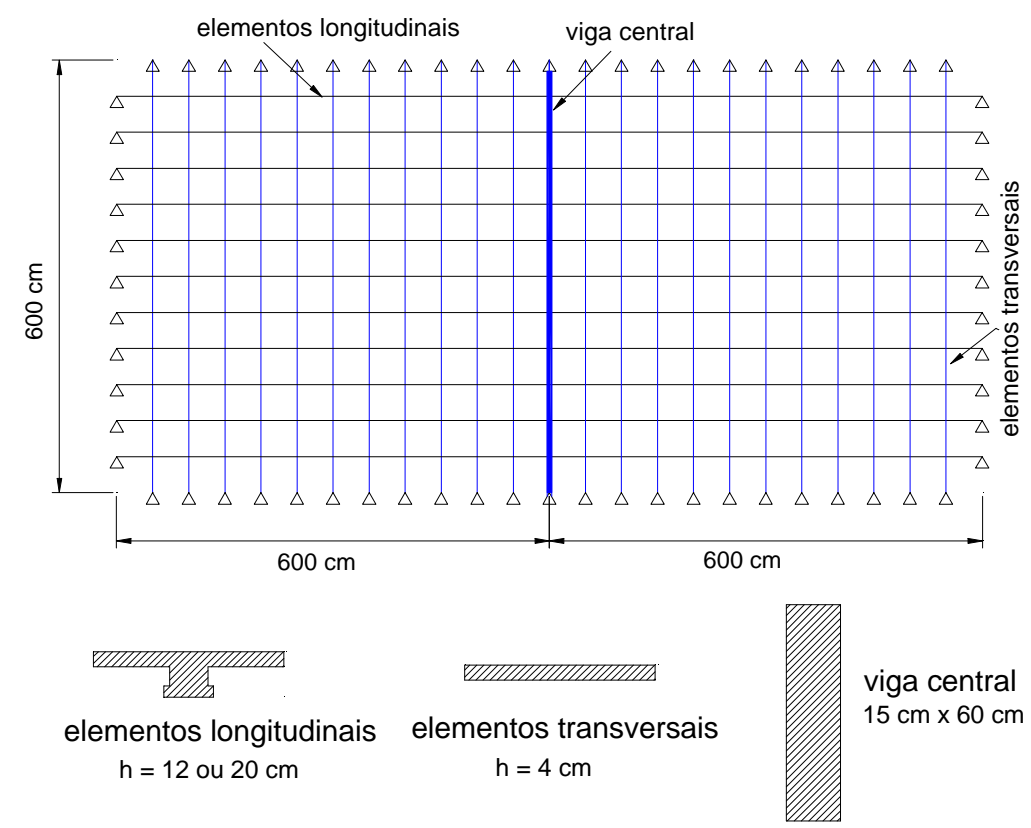

Fig.6.36 Grelha contínua

Determinam-se os valores de momento fletor através da análise linear (figura 6.37), considerando, para comparações, a rigidez à torção no estádio I e estádio II. Apresentam-se nas figuras 6.38 e 6.39 os valores de momento fletor obtidos na análise linear da grelha com comparações dos valores obtidos na viga contínua. 


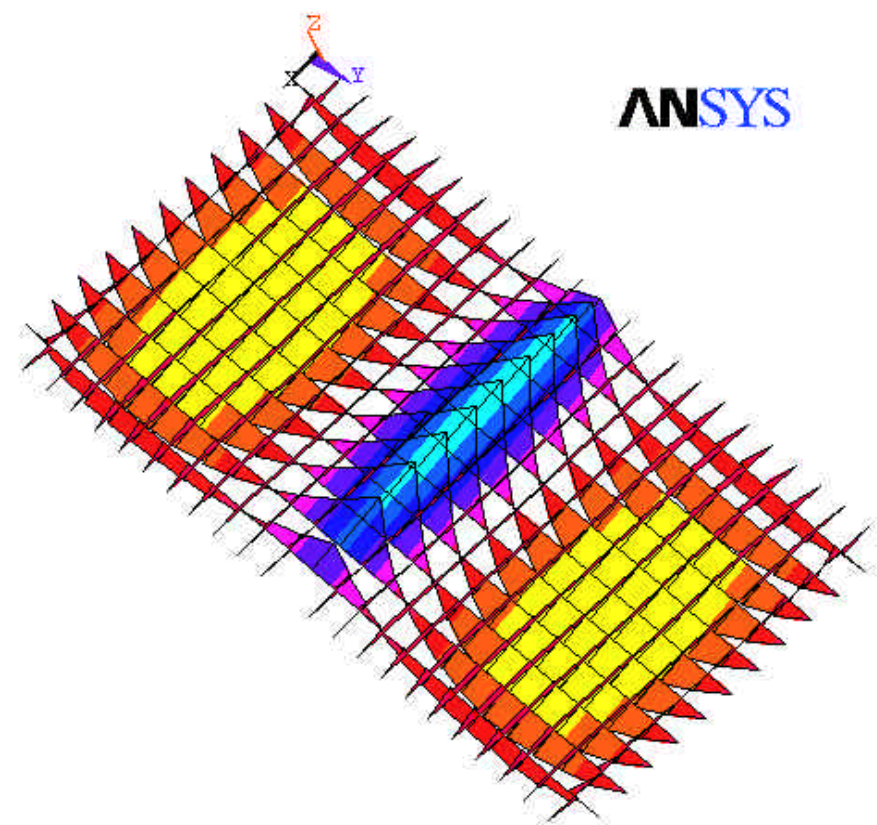

Fig.6.37 Diagrama de momento fletor - grelha contínua unidirecional

Através da análise linear, nota-se que praticamente não há diferenças em se considerar a rigidez à torção para o estádio I ou estádio II. Comparando-se os valores da viga contínua, há uma grande aproximação para a laje com altura igual a $12 \mathrm{~cm}$. Mas para a laje com altura igual a 20 $\mathrm{cm}$ há uma discrepância de cerca de $21 \%$ do valor do momento fletor negativo.

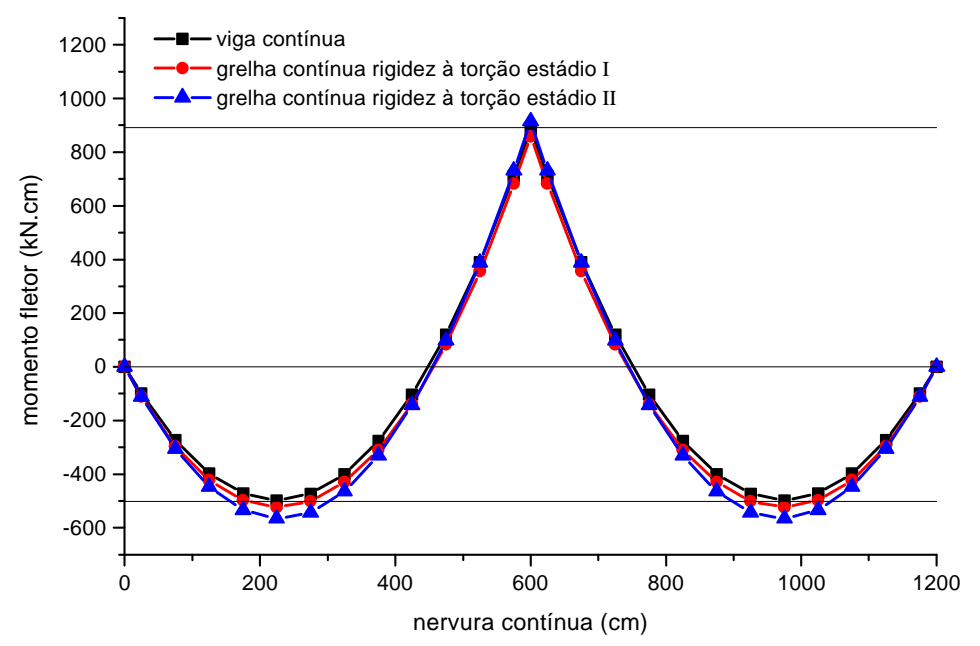

Fig.6.38 Diagrama de momento fletor - laje unidirecional - $\mathrm{h}=12 \mathrm{~cm}$ 


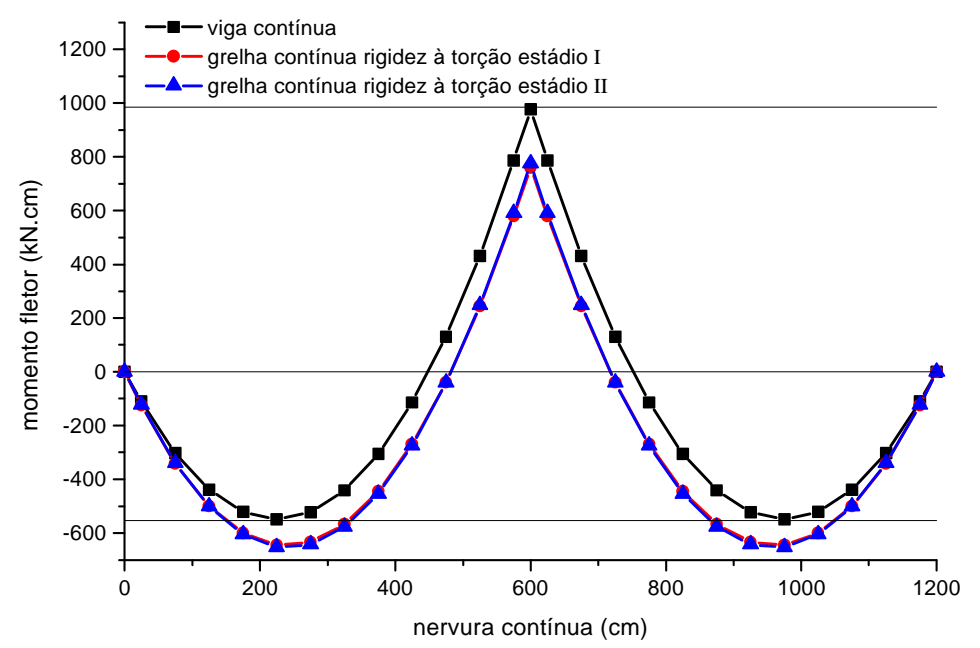

Fig.6.39 Diagrama de momento fletor - laje unidirecional $-\mathrm{h}=20 \mathrm{~cm}$

Para a análise não-linear da grelha contínua, considera-se o mesmo dimensionamento da viga contínua. Prevendo-se que ocorrerá redução do momento fletor negativo, principalmente devida à deformação da viga, considera-se na análise o dimensionamento referente à redução de $15 \mathrm{e}$ $50 \%$ do momento fletor negativo.

Nesta análise não linear adotam-se dois casos, um considerando o deslocamento da viga e outro com o deslocamento da viga impedido.

Para a viga central, é feito o dimensionamento da armadura com aço ( CA-50), em função do máximo momento fletor $(M)$ :

$$
\begin{aligned}
& \text { Laje } \mathrm{h}=12 \mathrm{~cm} \rightarrow M=13224 \mathrm{kN} . \mathrm{cm} \rightarrow \mathrm{A}_{\mathrm{s}}=9,27 \mathrm{~cm}^{2} \\
& \text { Laje } \mathrm{h}=20 \mathrm{~cm} \rightarrow M=14030 \mathrm{kN} . \mathrm{cm} \rightarrow \mathrm{A}_{\mathrm{s}}=10,21 \mathrm{~cm}^{2}
\end{aligned}
$$

Para verificar a redistribuição dos esforços, mediante a análise nãolinear, apresenta-se nas figuras 6.40 e 6.41 a variação do máximo momento fletor negativo para as grelhas representativas das lajes com altura igual a 12 e $20 \mathrm{~cm}$. 


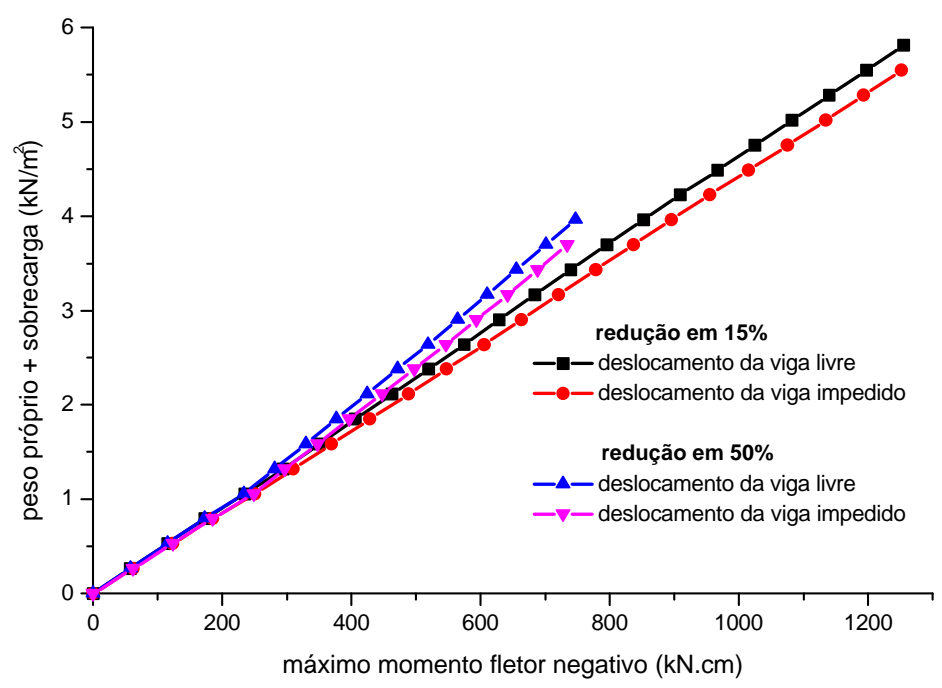

Fig.6.40 Variação do máximo momento fletor negativo $-\mathrm{h}=12 \mathrm{~cm}$

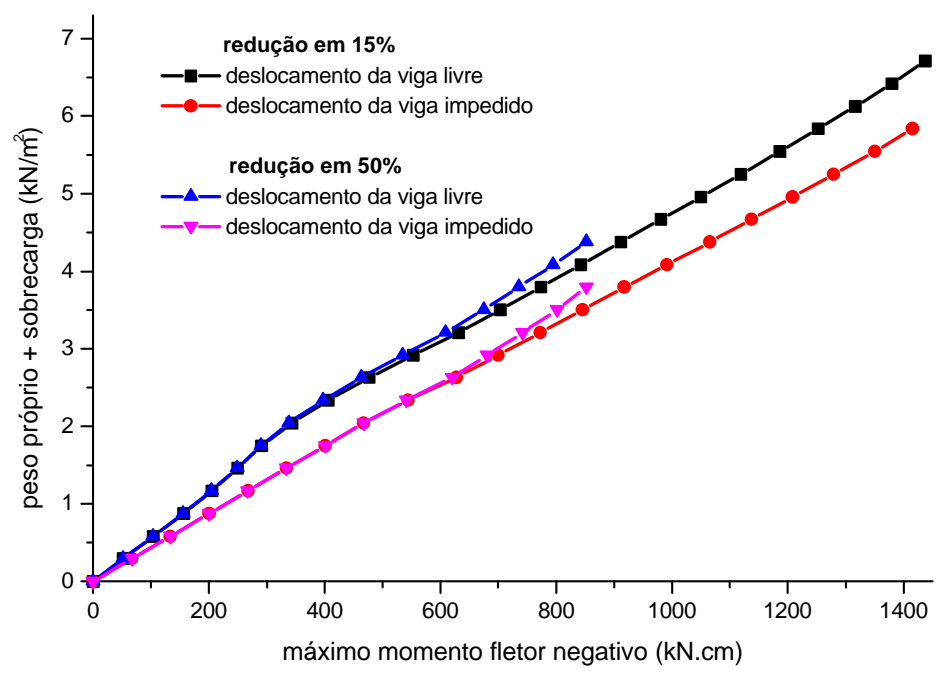

Fig.6.41 Variação do máximo momento fletor negativo - $\mathrm{h}=20 \mathrm{~cm}$

A seguir, na tabela 6.15 , mostram-se os valores de momento fletor negativo último através da análise não-linear em função do momento obtido pela análise linear. 
Tabela 6.15 Relação do momento negativo obtido pela análise não linear pelo momento negativo considerado para o dimensionamento da seção.

\begin{tabular}{|c|c|c|c|c|}
\hline \multirow{2}{*}{$\begin{array}{c}\text { altura } \\
\text { da laje }\end{array}$} & \multicolumn{1}{c|}{$\begin{array}{c}\text { \% redução: } \\
\text { (cm) }\end{array}$} & MNL./ 0,85. ML & \%0 \% redução: & MNL./ 0,5. ML \\
\cline { 2 - 5 } & livre & impedido & leslocamento da viga \\
\hline $\mathrm{h}=12$ & 1,13 & 1,18 & 1,67 & impedido \\
\hline $\mathrm{h}=20$ & 1,12 & 1,27 & 1,73 & 2,76 \\
\hline
\end{tabular}

MNL - Momento fletor negativo (análise não-linear)

$\mathrm{ML}$ - Momento fletor negativo (análise linear)

Nas figuras 6.42 e 6.43, apresentam-se as curvas de deslocamentos máximos das lajes unidirecionais contínuas mediante a análise não-linear. $O$ último ponto de cada diagrama refere-se a atuação do carregamento que atinge o Estado Limite Último ou momento fletor último da seção de concreto armado.

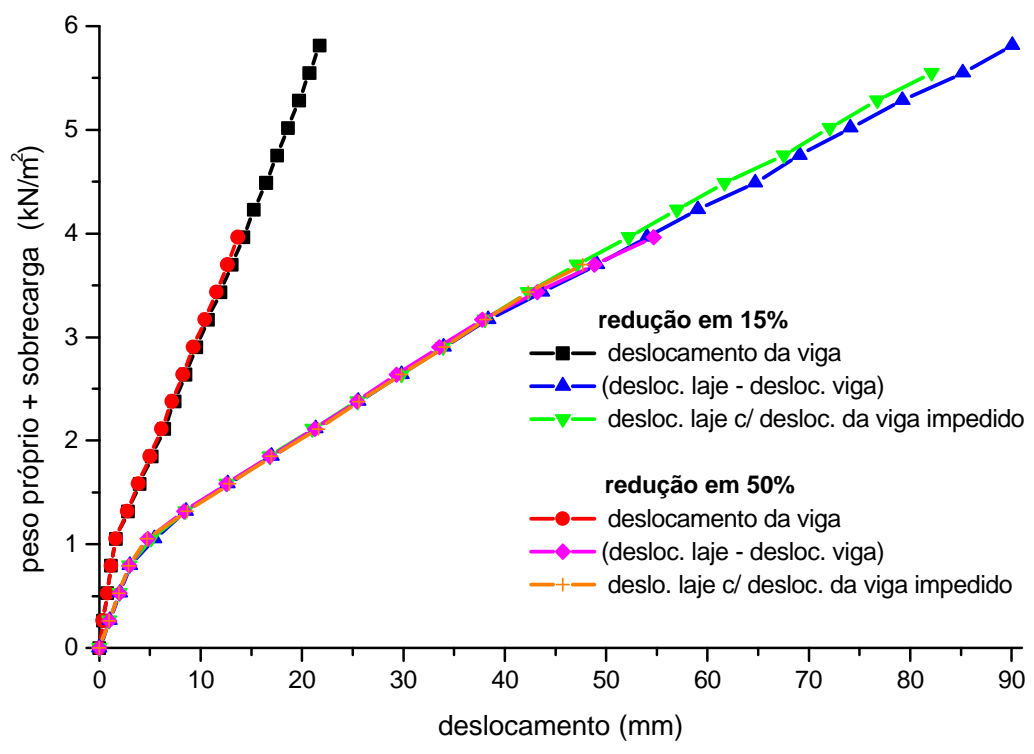

Fig.6.42 Carregamento $x$ deslocamento -grelha contínua - $h=12 \mathrm{~cm}$ 


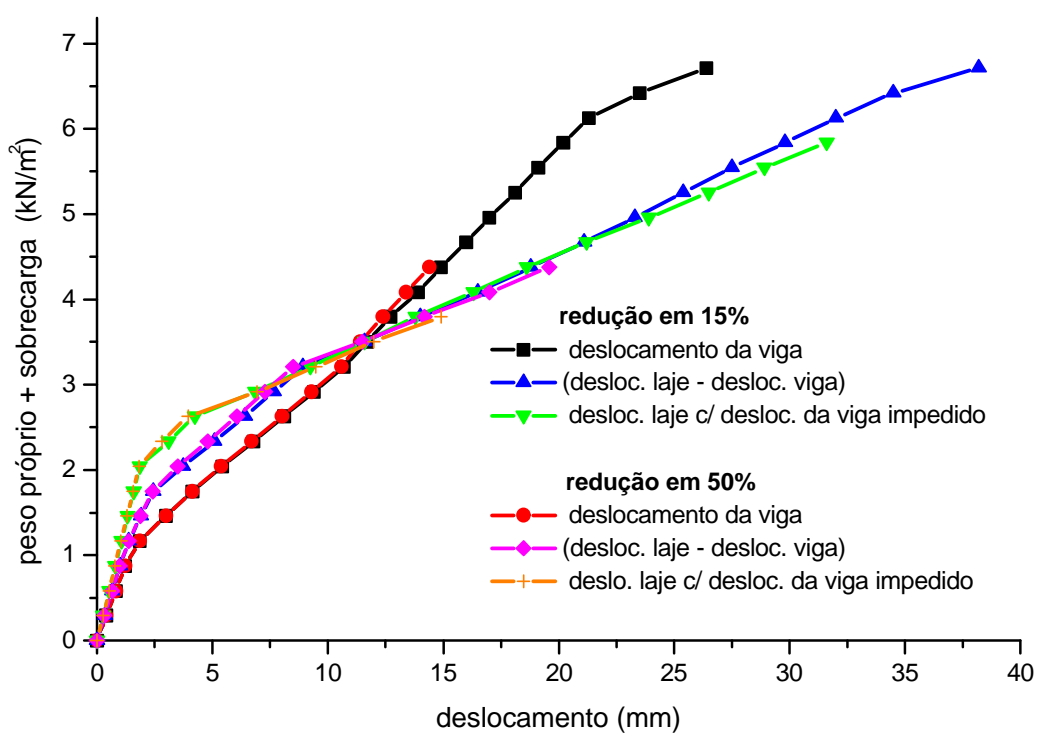

Fig.6.43 Carregamento $x$ deslocamento -grelha contínua - $\mathrm{h}=20 \mathrm{~cm}$

Neste estudo de grelha contínua, analisa-se a continuidade das nervuras formadas pelas vigotas pré-moldadas. A seguir, como complemento, apresenta-se a análise linear da grelha em que estas nervuras (nervuras principais), são dispostas em direções ortogonais, como pode ser visto na figura 6.44. As dimensões da viga central são as mesmas da análise anterior.

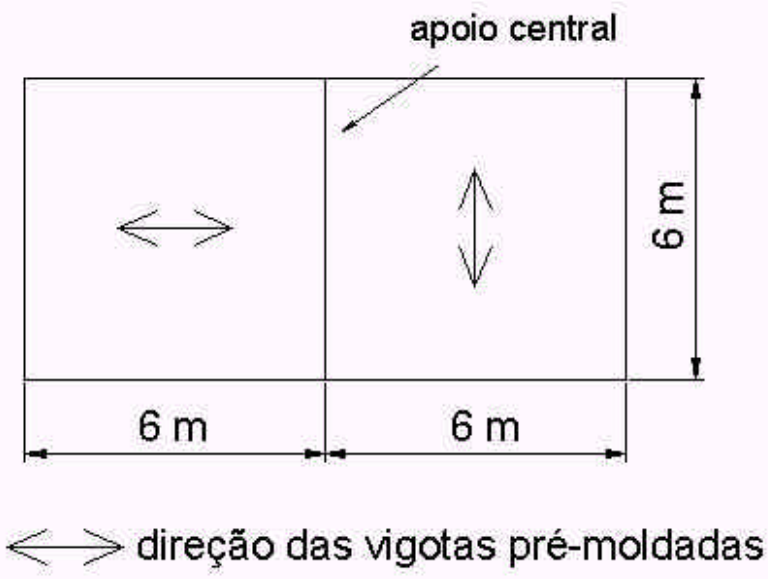

Fig.6.44 Laje unidirecional contínua - disposição das vigotas pré-moldadas em direções opostas 
Determinam-se os valores de momento fletor através da análise linear, considerando, para comparações, a rigidez à torção no estádio I e estádio II. São apresentados nas figuras 6.45 e 6.46 os valores de momento fletor nos elementos centrais da grelha, obtidos na análise linear.

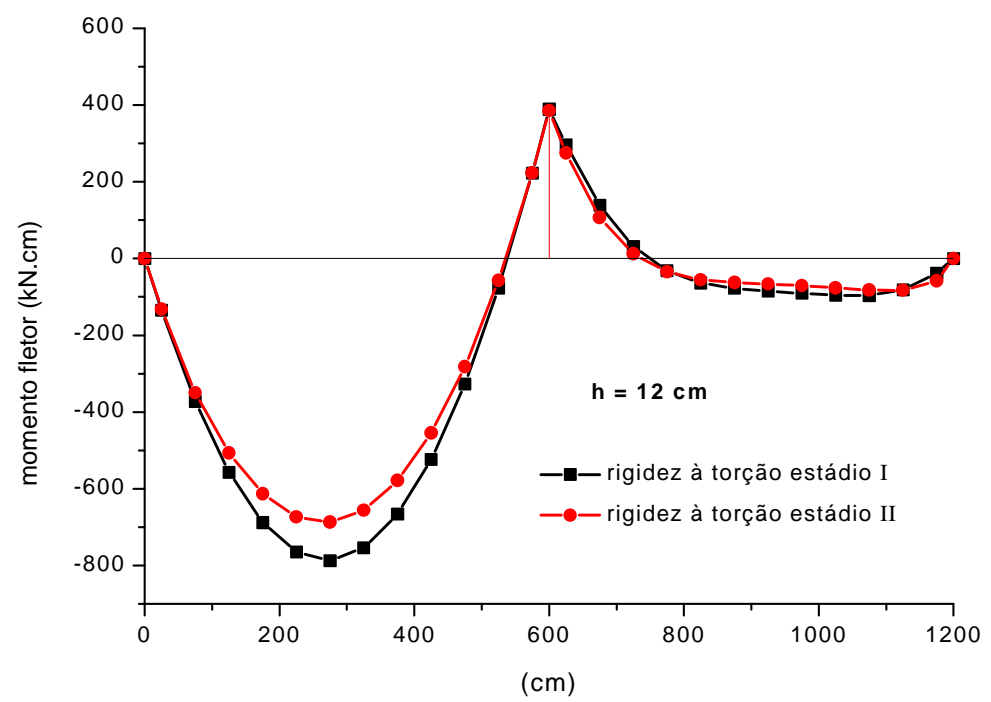

Fig.6.45 Diagrama de momento fletor - grelha contínua $-\mathrm{h}=12 \mathrm{~cm}$

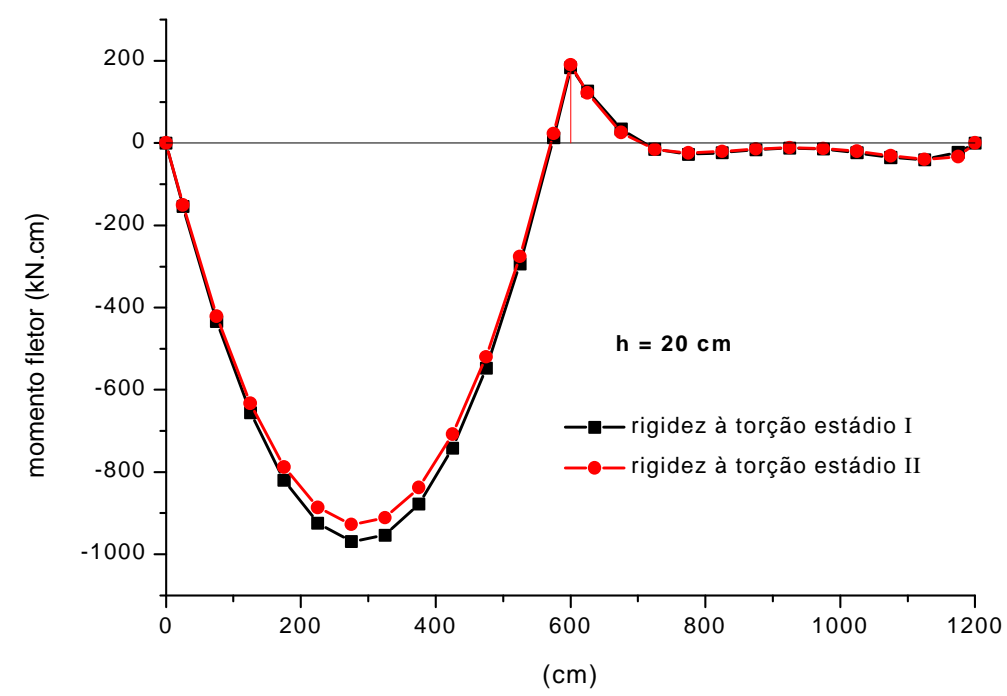

Fig.6.46 Diagrama de momento fletor - grelha contínua $-\mathrm{h}=20 \mathrm{~cm}$ 
Apresenta-se a seguir nas tabelas 6.16 e 6.17 os valores de deslocamento obtidos na análise linear e não-linear, em função das combinações freqüentes das ações $\left(F_{d}\right)$, sendo as ações:

a) para laje unidirecional

$F_{d(\mathrm{~h}=12)}=2,56 \mathrm{kN} / \mathrm{m}^{2} \quad, \quad F_{d(\mathrm{~h}=20)}=2,98 \mathrm{kN} / \mathrm{m}^{2}$

b) laje bidirecional

$F_{d(\mathrm{~h}=12)}=2,80 \mathrm{kN} / \mathrm{m}^{2} \quad, F_{d(\mathrm{~h}=20)}=3,54 \mathrm{kN} / \mathrm{m}^{2}$

Para os arranjos considerados, tem-se que a flecha máxima em Estado Limite de Utilização é igual a $2 \mathrm{~cm}$.

Tabela 6.16 Flecha nas lajes com altura igual a $12 \mathrm{~cm}(\mathrm{em} \mathrm{cm})$

\begin{tabular}{|c|c|c|c|c|c|}
\hline \multirow{2}{*}{\multicolumn{2}{|c|}{ altura da laje igual a $12 \mathrm{~cm}$}} & \multirow{2}{*}{$\begin{array}{l}\text { formato } \\
\text { em planta }\end{array}$} & \multirow{2}{*}{$\begin{array}{c}\text { análise } \\
\text { não-linear }\end{array}$} & \multicolumn{2}{|c|}{ análise linear } \\
\hline & & & & rig. torção est. I & rig. torção est. II \\
\hline viga simplesmente apoiada & & * & 5,6 & 2,1 & * \\
\hline viga contínua & & * & 3.0 & 1.0 & * \\
\hline \multirow{2}{*}{\multicolumn{2}{|c|}{ laje unidirecional }} & $6,0 \mathrm{~m} \times 6,0 \mathrm{~m}$ & 5,2 & 2,1 & 2,4 \\
\hline & & $12,0 \times 6,0 \mathrm{~m}$ & 5,9 & 2,1 & 2,1 \\
\hline \multirow{2}{*}{\multicolumn{2}{|c|}{ laje unidirecional c/ nerv. transversais }} & $6,0 \mathrm{~m} \times 6,0 \mathrm{~m}$ & 4,7 & 1,9 & 2.1 \\
\hline & & $12,0 \times 6,0 \mathrm{~m}$ & 6,1 & 2,3 & 2,3 \\
\hline \multirow{2}{*}{\multicolumn{2}{|c|}{ laje bidirecional }} & $6,0 \mathrm{~m} \times 6,0 \mathrm{~m}$ & 5,4 & 1,8 & 2.0 \\
\hline & & $12,0 \times 6,0 \mathrm{~m}$ & 5,7 & 2,5 & 2,5 \\
\hline \multirow{2}{*}{$\begin{array}{c}\text { laje unidirecional com rigidez à torção } \\
\text { das vigas de extremidade: }\end{array}$} & estádio I & $6,0 \mathrm{~m} \times 6,0 \mathrm{~m}$ & 1,3 & 1.0 & 1,8 \\
\hline & estádio II & $6,0 \mathrm{~m} \times 6,0 \mathrm{~m}$ & 2,5 & * & * \\
\hline \multirow{2}{*}{$\begin{array}{c}\text { laje bidirecional com rigidez à torção } \\
\text { das vigas de extremidade: }\end{array}$} & estádio I & $6,0 \mathrm{~m} \times 6,0 \mathrm{~m}$ & 1,1 & 0,9 & 1,6 \\
\hline & estádio II & $6,0 \mathrm{~m} \times 6,0 \mathrm{~m}$ & 1,5 & * & * \\
\hline \multirow{2}{*}{$\begin{array}{l}\text { laje unidirecional continua com o } \\
\text { deslocamento da viga de apoio: }\end{array}$} & livre & $12,0 \times 6,0 \mathrm{~m}$ & 2,8 & * & * \\
\hline & impedido & $12,0 \times 6,0 \mathrm{~m}$ & 2,8 & 1,1 & 1,2 \\
\hline
\end{tabular}


Tabela 6.17 Flecha nas lajes com altura igual a $20 \mathrm{~cm}(\mathrm{em} \mathrm{cm})$

\begin{tabular}{|c|c|c|c|c|c|}
\hline \multirow{2}{*}{\multicolumn{2}{|c|}{ altura da laje igual a $20 \mathrm{~cm}$}} & \multirow{2}{*}{$\begin{array}{l}\text { formato } \\
\text { em planta }\end{array}$} & \multirow{2}{*}{$\begin{array}{l}\text { análise } \\
\text { não-linear }\end{array}$} & \multicolumn{2}{|c|}{ análise linear } \\
\hline & & & & rig. torção est. I & rig. torção est. II \\
\hline viga simplesmente apoiada & & * & 2,7 & 0,6 & * \\
\hline viga contínua & & * & 0,7 & 0,3 & * \\
\hline \multirow{2}{*}{\multicolumn{2}{|c|}{ laje unidirecional }} & $6,0 \mathrm{~m} \times 6,0 \mathrm{~m}$ & 2,4 & 0,6 & 0,7 \\
\hline & & $12,0 \times 6,0 \mathrm{~m}$ & 2,6 & 0,6 & 0,6 \\
\hline \multirow{2}{*}{\multicolumn{2}{|c|}{ laje unidirecional c/ nerv. transversais }} & $6,0 \mathrm{~m} \times 6,0 \mathrm{~m}$ & 2.0 & 0,6 & 0,6 \\
\hline & & $12,0 \times 6,0 \mathrm{~m}$ & 2,8 & 0,6 & 0,7 \\
\hline \multirow{2}{*}{\multicolumn{2}{|c|}{ laje bidirecional }} & $6,0 \mathrm{~m} \times 6,0 \mathrm{~m}$ & 1,6 & 0,3 & 0,5 \\
\hline & & $12,0 \times 6,0 \mathrm{~m}$ & 2,7 & 0,5 & 0,8 \\
\hline \multirow{2}{*}{$\begin{array}{c}\text { laje unidirecional com rigidez à torção } \\
\text { das vigas de extremidade: }\end{array}$} & estádio I & $6,0 \mathrm{~m} \times 6,0 \mathrm{~m}$ & 0,9 & 0,5 & 0,6 \\
\hline & estádio II & $6,0 \mathrm{~m} \times 6,0 \mathrm{~m}$ & 1,6 & * & * \\
\hline \multirow{2}{*}{$\begin{array}{c}\text { laje bidirecional com rigidez à torção } \\
\text { das vigas de extremidade: }\end{array}$} & estádio I & $6,0 \mathrm{~m} \times 6,0 \mathrm{~m}$ & 0,6 & 0,8 & 0,5 \\
\hline & estádio II & $6,0 \mathrm{~m} \times 6,0 \mathrm{~m}$ & 1,2 & * & * \\
\hline \multirow{2}{*}{$\begin{array}{l}\text { laje unidirecional continua com o } \\
\text { deslocamento da viga de apoio: }\end{array}$} & livre & $12,0 \times 6,0 \mathrm{~m}$ & 0,8 & * & * \\
\hline & impedido & $12,0 \times 6,0 \mathrm{~m}$ & 0,7 & 0,3 & 0,3 \\
\hline
\end{tabular}

\subsubsection{ANÁLISE DOS RESULTADOS}

$\mathrm{Na}$ análise linear das lajes, segundo a analogia de grelha, 2 parâmetros foram observados. O primeiro é referente à rigidez à torção dos elementos, que, quando considerados, como é de se esperar, reduzem o valor do momento fletor. Pela falta de estudos específicos da capacidade destas lajes em oferecerem a rigidez à torção e também pela sua não obrigatoriedade para o equilíbrio estrutural, esta rigidez geralmente é desprezada desprezada.

O segundo parâmetro é referente à rigidez à flexão das barras transversais da grelha. Segundo os gráficos das figuras 6.13 e 6.14 nota-se que, para painéis de laje com formato quadrado, a rigidez à flexão na direção transversal reduz o valor de momento fletor na direção longitudinal. Mas somente a partir de um certo valor da rigidez transversal; pois para valores pequenos, ocorre o aumento do máximo momento fletor na direção longitudinal maior até mesmo do que os valores obtidos mediante análise em modelos de viga bi-apoiada.

Para painéis de laje com formato retangular, com a relação entre os lados próximos de 2, observa-se que a rigidez à flexão na direção 
transversal não diminui o momento fletor na direção longitudinal, pelo contrário, aumenta. Nos diagramas vistos nas figuras 6.15 a 6.18 pode-se notar o comportamento do momento fletor na direção transversal para este formato de laje. Nota-se que ao caminhar para o meio do vão, praticamente não há momento fletor nas nervuras transversais, ou seja, não há contribuição para reduzir o momento fletor na direção longitudinal.

A adoção de lajes bidirecionais para lajes com a relação entre vãos próximos ou maiores que 2 torna-se pouco interessante.

A determinação dos valores de momento fletor para as lajes bidirecionais de acordo com as tabelas, como, por exemplo, BARES (1972), utilizadas para lajes maciças acarretam diferenças maiores de que 50\%. Isto ocorre pelo fato de que as lajes bidirecionais executadas com vigotas prémoldadas resultam em seções transversais distintas entre as direções longitudinais e transversais da laje. A seção constituída pela vigota prémoldada terá maior inércia à flexão do que a seção na outra direção, pois a seção da nervura na direção transversal possui menor altura devido ao processo executivo utilizado. A determinação dos momentos fletores fazendo a analogia da laje pré-moldada bidirecional com a laje maciça tornase aceitável desde que se tenha valores próximos de rigidez nas duas direções como ocorre, por exemplo, em lajes nervuradas bidirecionais moldadas no local.

Comparando os deslocamentos entre os arranjos de nervura simplesmente apoiada (modelo de viga), laje unidirecional com e sem nervuras transversais e laje bidirecional (modelos de grelha) tem-se que:

a) Os deslocamentos obtidos através dos arranjos de laje unidirecional com e sem nervura de travamento, são próximas dos valores obtidos no modelo de viga. Prevalecendo o comportamento unidirecional; 
b) Nota-se a pouca redução dos deslocamentos com a consideração das "nervuras de travamento" nas lajes unidirecionais. A princípio, portanto, pode-se desprezá-la. Porém, esta análise foi feita considerando apenas carregamentos distribuídos. Com a introdução de carregamentos adicionais, como por exemplo, paredes, as "nervuras de travamento" desempenham um importante papel, que é o de reduzir os deslocamentos relativos entre as nervuras vizinhas com carregamentos diferentes;

c) Para os modelos de laje bidirecional, como é esperado, ocorre uma boa redução dos deslocamentos (comparados com modelos de laje unidirecional) para a altura da laje igual a $20 \mathrm{~cm}$ e formato em planta quadrada $(6 \mathrm{~m} \times 6 \mathrm{~m})$, há uma redução dos deslocamentos da ordem de $40 \%$. Mas para a altura de laje igual a $12 \mathrm{~cm}$ é observado deslocamento próximo das lajes unidirecionais (lembrando que a laje bidirecional tem maior peso próprio);

d) À medida que aumenta a relação entre os vãos, e sendo dispostas as vigotas pré-moldadas no menor vão, existe uma maior aproximação dos arranjos de laje unidirecional com o modelo de viga bi-apoiada. Nas lajes bidirecionais, aumenta-se o deslocamento aproximando-se dos modelos de viga bi-apoiada. Confirma-se, portanto a pouca eficiência de lajes bidirecionais para painéis de laje com relação entre vãos iguais ou próximos a 2;

e) Em termos de momento fletor, tem-se em geral, que os valores determinados pela análise não-linear são menores do que os valores utilizados para o dimensionamento. Atenção especial deve ser dada às lajes retangulares com relação entre vãos próximos de 2, pois, como é visto nas tabela 6.10 e 6.11, existe um maior momento atuante do que o admitido no dimensionamento (nervura simplesmente apoiada); 
f) Como pode ser visto nas Tabelas 6.16 e 6.17, os valores de deslocamentos obtidos segundo a análise não-linear são na maior parte dos casos superiores ao valor da flecha admissível de $2 \mathrm{~cm}$. Salienta-se, também que nesta análise não está sendo considerado os efeitos da retração e deformação lenta do concreto. Nota-se, portanto, a grande importância da análise dos deslocamentos nestas lajes.

As vigas de extremidade exercem influência nos valores de momento fletor nas lajes, sendo função da sua rigidez à torção. Como pode ser visto nas figuras 6.30 e 6.31, que mostram o máximo momento fletor negativo nas nervuras das lajes unidirecionais para a rigidez à torção das vigas de extremidade no estádio I e II.

Em arranjos com vigas de extremidade, a princípio, a idéia original era fazer a análise não-linear da grelha, considerando a variação da rigidez à torção em todos os elementos, como foi feito para as grelhas sem vigas de extremidade.

A variação da rigidez à torção, como comentado em 3.4, é função do momento fletor atuante no elemento, e não em função do momento de torção. Deste modo, a rigidez à torção das vigas de extremidade será função do momento fletor atuante.

Considerou-se, portanto, esta hipótese. Mas para isto, teve-se que apoiar as vigas apenas nas suas extremidades para que a mesma pudesse ser solicitada ao momento fletor, ou seja, deixá-la com o deslocamento vertical livre.

A análise não-linear com esta consideração não foi satisfatória, visto que a mesma foi influenciada pela deformação da viga e o mais importante, que é a simplificação adotada para a determinação do estádio de comportamento à torção dos elementos.

Devido a isto, a anállise de grelhas com vigas de extremidade foi realizada considerando a rigidez destas vigas constantes, sendo obtidas duas curvas, uma para a rigidez das vigas de extremidade para o estádio I e 
a outra para a rigidez no estádio II. Esta mesma consideração foi feita na análise teórico-experimental da laje bidirecional do capítulo 5.

Através dos diagramas das figuras 6.32 a 6.35 vemos que com a contribuição da rigidez à torção das vigas existe uma grande redução dos deslocamentos. A redução dos deslocamentos é maior para a laje com altura igual a $12 \mathrm{~cm}$, pois como é de se esperar, a influência será maior, quanto maior for a relação entre a rigidez à torção das vigas de extremidade com a das nervuras da laje.

Nesta análise obtêm-se duas curvas de deslocamento, sendo estas curvas de referência limitantes, ou seja, espera-se que o deslocamento real da estrutura esteja compreendido entre estas curvas.

A análise da continuidade através do modelo de grelha, do mesmo modo que para o modelo de viga nos mostram que:

a) A principal vantagem da consideração da continuidade é a expressiva redução dos deslocamentos se comparados com os valores obtidos em modelos isolados. Nesta análise obtém-se redução de deslocantos da ordem de 50 e $70 \%$ para as lajes com altura igual a 12 e 20 $\mathrm{cm}$, respectivamente;

b) Com imposições de valores de momento fletor negativo menor do que os obtidos segundo a análise linear, nota-se na análise não-linear que não ocorre esta redução, ou seja, há pouca redistribuição de esforços;

c) Neste arranjo foi possível avaliar a influência da deformabilidade da viga, sendo maior na laje com altura igual a $20 \mathrm{~cm}$. Ou seja, há uma redução de 10 a $14 \%$ do momento fletor negativo comparado com o modelo de viga indeslocável;

d) A influência da deformabilidade da viga, nos valores de máximo deslocamento da laje pode ser vista na laje com altura igual a $20 \mathrm{~cm}$ (figura 
6.43). Esta influi no início de fissuração dos elementos submetidos ao momento fletor negativo, entretanto, a diferença é pequena e ocorre apenas em um trecho da curva;

e) Em casos onde não se tem a continuidade entre as nervuras, ou seja, quando estas são dispostas em direções opostas, nota-se que ocorre a interação da nervura com a capa de concreto, surgindo momento fletor negativo. Nota-se nos diagramas das figuras 6.45 e 6.46 que quanto menor a diferença de rigidez entre a nervura e a capa de concreto, maior será o valor de momento negativo devido à continuidade entre os elementos;

Neste caso, tem-se que para a altura de laje igual a $12 \mathrm{~cm}$, o valor do momento fletor negativo é da ordem de $50 \%$ do momento fletor positivo, e para a laje com altura igual a $20 \mathrm{~cm}$, o momento fletor negativo representa $20 \%$ do valor do momento fletor positivo. 


\section{CONSIDERAÇÕES FINAIS E CONCLUSÕES}

Neste trabalho procurou-se fazer uma avaliação do comportamento estrutural geral das lajes nervuradas treliçadas. Esta avaliação mostrou particularidades e parâmetros que definem ou influem no comportamento estrutural destas lajes.

O modelo teórico adotado para as análises foi avaliado através de comparações entre valores experimentais, sendo que nestas obteve-se as principais conclusões:

a) A adoção da relação momento $x$ curvatura do CEB-90, para a análise não-linear em modelos de vigas bi-apoiadas, resultou em uma boa aproximação com os valores experimentais. A formulação de BRANSON para estes modelos também foi satisfatória, sendo este um bom modelo para avaliar as flechas em serviço. Este modelo não expressa o aumento do deslocamento devido ao escoamento.

b) $\mathrm{Na}$ análise teórica-experimental dos painéis de laje com telas soldadas através de modelos de vigas contínuas têm-se que para as lajes com baixa taxa de armadura ocorre discrepância entre os valores de deslocamento teóricos com experimentais. Admite-se que isto ocorra devido 
à estimativa da resistência média à tração por flexão do concreto, que influi no valor de início de fissuração. Para taxas de armadura maiores há uma melhor aproximação dos valores. Segundo a análise não-linear, mediante 0 carregamento incremental, é observado que a variação do momento fletor é praticamente linear, ou seja, não há redistribuição de esforços, pois do mesmo modo que ocorre a diminuição da rigidez em elementos submetidos ao momento fletor negativo, ocorre o mesmo para os elementos submetidos ao momento fletor positivo.

c) No estudo das lajes pré-moldada, visto segundo a análise teóricaexperimental através de um ensaio de laje pré-moldada e modelo de grelha, têm-se boas aproximações entre os valores de deslocamentos. Nesta análise podemos notar a influência da rigidez à torção das nervuras. Sendo um parâmetro determinante para se estimar o deslocamento. Neste modelo, com a consideração da rigidez à torção constante do estádio II a diferença entre os valores de deslocamento teórico e experimental é de 170\%, confirmando a grande influência deste parâmetro. Embora se trate de apenas um modelo de laje e também somente um tipo (laje bidirecional) pode-se concluir que em termos de cálculo de deslocamentos, o modelo alcança valores satisfatórios.

Com base nas simulações numéricas, procurou-se considerar diferentes tipos e dimensões da laje pré-moldada, segundo os modelos de viga e de grelha. Nesta análise teórica, as principais conclusões são:

a) Segundo os modelos de grelha, conclui-se que para a determinação dos esforços solicitantes e reação de apoio é conveniente que se utilizem programas de análise estrutural para considerar a interação entre os elementos. Para lajes unidirecionais, há uma grande aproximação dos esforços calculados com modelo de grelha e vigas bi-apoiadas, podendo-se considerar este método mais simplificado de determinação de esforços. Mas para as lajes bidirecionais, a consideração de tabelas (como por exemplo, 
BARES) para a determinação dos esforços só poderá ser feita se as nervuras longitudinais e transversais tiverem as dimensões ou rigidezes iguais ou próximas. Lembrando que ao utilizar as tabelas de BARES é feita uma analogia da laje nervurada com a laje maciça.

b) Os valores de deslocamentos obtidos nas lajes unidirecionais são muito próximos dos valores obtidos nas vigas bi-apoiadas, prevalecendo 0 comportamento unidirecional. A adoção de nevuras transversais influi muito pouco na distribuição dos esforços e nos valores de deslocamentos, sendo, portanto, considerados apenas como disposições construtivas. Lembrando que estas nervuras desempenham um importante papel, que é o de reduzir os deslocamentos relativos entre as nervuras vizinhas com carregamentos diferentes, como por exemplo, paredes apoiadas sobre as nervuras.

c) Para as lajes bidirecionais, ocorre, como esperado, redução dos deslocamentos. Mas nota-se uma expressiva redução somente para a laje com a altura igual a $20 \mathrm{~cm}$ (redução de $40 \%$, comparada com a laje unidirecional). Conclui-se que a eficiência das lajes bidirecionais será função da maior diferença entre a altura total da laje com a altura da capa de concreto.

d) O formato em planta da laje influi no comportamento estrutural, sendo mais expressivo nas lajes bidirecionais, ou seja, para a relação de lados próxima a 2, os valores máximos de momento fletor nas nervuras com menor vão são cerca de $50 \%$ maiores do que os valores obtidos com a laje com dimensões em planta iguais. Os deslocamentos são também maiores, à medida que aumenta a relação entre os lados da laje.

e) Como conclusão da consideração das vigas de extremidade tem-se que estas influem na distribuição dos valores de momento fletor na nervura e nos deslocamentos. Sendo esta influência função da rigidez à torção da 
viga, da altura da laje e da existência de armadura (dimensionada para o momento fletor negativo) posicionada na capa de concreto, sob a nervura.

$\mathrm{Na}$ análise teórica nota-se que para a laje com altura igual a $12 \mathrm{~cm}$ há uma maior influência da viga de extremidade, isto ocorre pelo fato de que a relação entre a rigidez da nervura com a rigidez da viga é menor do que para a nervura com altura igual a $20 \mathrm{~cm}$.

g) $\mathrm{Na}$ análise da continuidade, através do modelo de viga e grelha contínua, obtém-se pouca redistribuição de esforços. Ou seja, os valores de momento fletor obtidos pela análise não-linear são próximos dos obtidos pela análise não-linear. Segundo esta análise, conclui-se que os valores de momento fletor a serem considerados devem ser iguais aos obtidos através da análise linear, pois do mesmo modo que ocorre a diminuição da rigidez em elementos submetidos ao momento fletor negativo, ocorre o mesmo para os elementos submetidos ao momento fletor positivo.

Devido à reduzida seção de concreto na seção submetida ao momento fletor negativo, o seu dimensionamento pode resultar em armadura dupla. A armadura de compressão poderá ser disposta sobre a base de concreto da vigota treliçada. A consideração da armadura da vigota como armadura de compressão, só poderá ser feita se for possível estabelecer a continuidade entre a armadura das vigotas adjacentes.

Para vigotas contínuas sob apoio intermediário deformável, obtém-se a redução do momento fletor negativo, sendo este valor, função das dimensões da viga de apoio da laje, que a caracteriza como uma viga pouco ou muito deformável. Esta redução, a princípio, pode ser desconsiderada.

h) Até mesmo em casos onde a continuidade ocorre entre uma nervura e a capa de concreto obtém-se valores expressivos de momento fletor negativo através da análise linear. Nesta análise o efeito da continuidade é maior para a laje com altura igual a $12 \mathrm{~cm}$. Os resultados indicam que quanto menor a diferença entre a altura da laje e a altura da 
capa de concreto, maior será o efeito da continuidade entre lajes com este tipo de disposição das vigotas.

Verifica-se, portanto, a importância da adoção da armadura negativa nas regiões próximas ao apoio até mesmo quando não há arranjos com disposições paralelas ou contínuas das vigotas.

i) A reação de apoio da laje nervurada pré-moldada, como pode ser visto na tabela 6.11 do capítulo 6 , depende do arranjo estrutural adotado, sendo, portanto, de fundamental importância a determinação através de modelos que consideram a interação entre a rigidez dos diversos elementos estruturais. Nesta análise teórica, a reação de apoio das nervuras longitudinais, expressa por parcela do carregamento distribuído foi de 83 a $91 \%$ para a laje unidirecional; 73 a $82 \%$ para a laje unidirecional com "nervuras de travamento" e de 55 a $74 \%$ para a laje bidirecional.

A análise segundo a analogia de grelha para as lajes nervurada é, sem dúvida, um bom modelo, pois representa muito bem a interação dos elementos e o mais importante que é a facilidade de analisar os esforços e deslocamentos. Recomenda-se o uso deste modelo em análises de lajes nervuradas.

Como complementação ou modificação do modelo teórico para futuros trabalhos, está no modo de considerar a variação da rigidez à torção. Ou seja, considerá-la variável em função do momento de torção presente na nervura.

Sugere-se também a implementação de modelos não-lineares mais complexos, substituindo-se o modelo de carregamento incremental por modelos de análise não-linear incremental-iterativa.

Sugere-se a avaliação da capacidade de rotação plástica das seções submetidas, principalmente ao momento fletor negativo. Deste modo, além da verificação do estado limite último em função das hipóteses de cálculo na 
ruína do concreto armado (domínios de deformação), verifica-se o valor da rotação última da seção.

Em termos de análises experimentais, sugerem-se ensaios de modo a verificar a variação da rigidez à torção dos elementos constituintes da laje e das vigas de extremidade. Nestes pode-se avaliar o grau de influência da rigidez à torção nos esforços e deslocamentos.

Sugerem-se ensaios em painéis pré-moldados unidirecionais com apoios na extremidade e um apoio central (estudo da continuidade). Nesta analise pode se avaliar o grau de redistribuição de esforços devido ao comportamento não-linear, e também de verificar a capacidade resistente da nervura submetida ao momento fletor negativo (colaboração do concreto comprimido da vigota pré-moldada e a solidarização do concreto moldado no local com a vigota).

Para finalizar ressalta-se a importância de uma adequada análise estrutural nas lajes, principalmente no que diz respeito às deformações, que em muitos casos é o fator limitante. Esta análise torna-se fundamental em arranjos com grandes vãos e/ou com carregamentos de alvenaria sob a laje. 


\section{ANEXO A}

DETERMINAÇÃO DOS MOMENTOS E CURVATURAS DE ESCOAMENTO DO AÇO OU PLASTIFICAÇÃO DO CONCRETO E DO ESTADO LIMITE ÚLTIMO

\section{A.1 CONSIDERAÇÕES INICIAIS}

A determinação dos momentos e curvaturas em uma dada seção transversal de concreto armado, permite o uso do modelo do CEB-90 (1991), apresentadas no capítulo 2. Para facilitar a determinação destes valores, desenvolve-se uma rotina de cálculo em FORTRAN (chamada de RIGIDEZ), de acordo com as equações a seguir.

Por se tratar do estudo do comportamento do elemento, os valores de resistência considerado nos diagramas tensão-deformação do concreto e do aço são valores médios indicados por $f_{c m}$ (resistência média à compressão do concreto) e $f_{y m}$ (resistência média à tração do aço).

O diagrama do concreto, relativo à compressão, é admitido de acordo com a NBR-6118 (1982), figura A.1. 


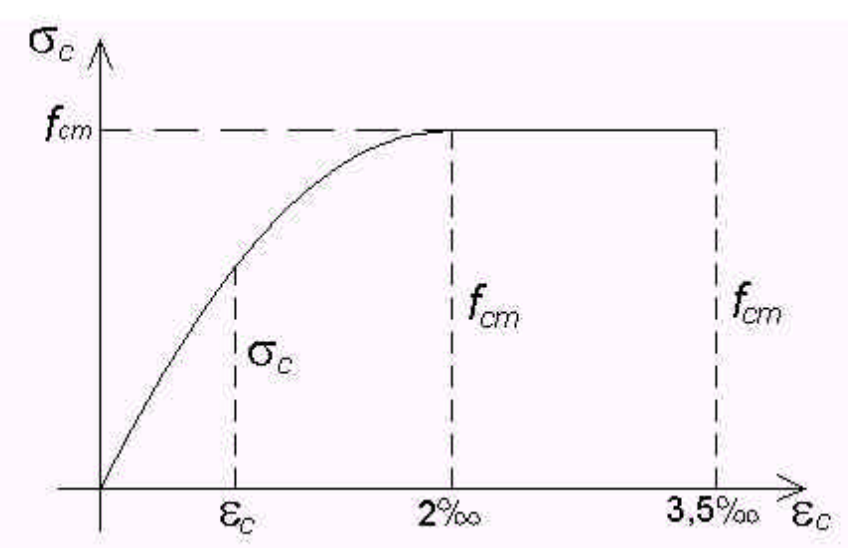

Fig. A.1 Diagrama tensão-deformação do concreto

O valor da tensão no concreto $\left(\sigma_{c}\right)$ para valores menores que a deformação $\left(\varepsilon_{c}\right)$ igual a $2 \%$ pode ser obtido mediante a equação vista em SANTOS (1983):

$$
\sigma_{c}=f_{c m}\left(\varepsilon_{c}-\frac{\varepsilon_{c}^{2}}{4}\right)
$$

Para o aço tem-se a distinção entre aço classe $A$ e classe $B$. A NBR-6118 permite simplificar o diagrama, adotando o diagrama da figura A.2, típico de material elasto-plástico perfeito, referente ao aço classe $A$.

Seja $\varepsilon_{s y}$ a deformação específica ou convencional correspondente ao início do escoamento, a tensão no aço $\left(\sigma_{s}\right)$ para deformação menor do que $\varepsilon_{s y}$ é calculada:

$$
\sigma_{s}=E_{s} \varepsilon_{s}
$$

Aço classe A: $\varepsilon_{s y}=\frac{f_{y m}}{E_{s}} \quad$ sendo,

$E_{s}$ - Módulo de elasticidade do aço $=210 \mathrm{GPa}$ 


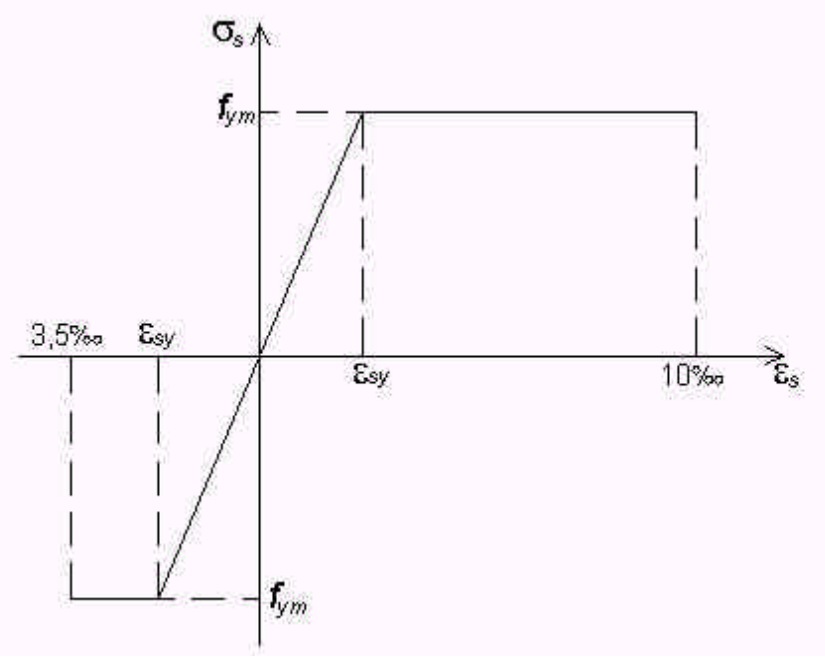

Fig. A.2 Diagrama tensão-deformação do aço classe A

Para o aço classe B (figura A.3) permite-se um diagrama simplificado composto de três trechos; um trecho linear, um trecho curvo entre 0,7 $f_{y m}$ e o ponto correspondente à resistência de escoamento convencional $f_{y m}$ e um patamar deste ponto em diante.

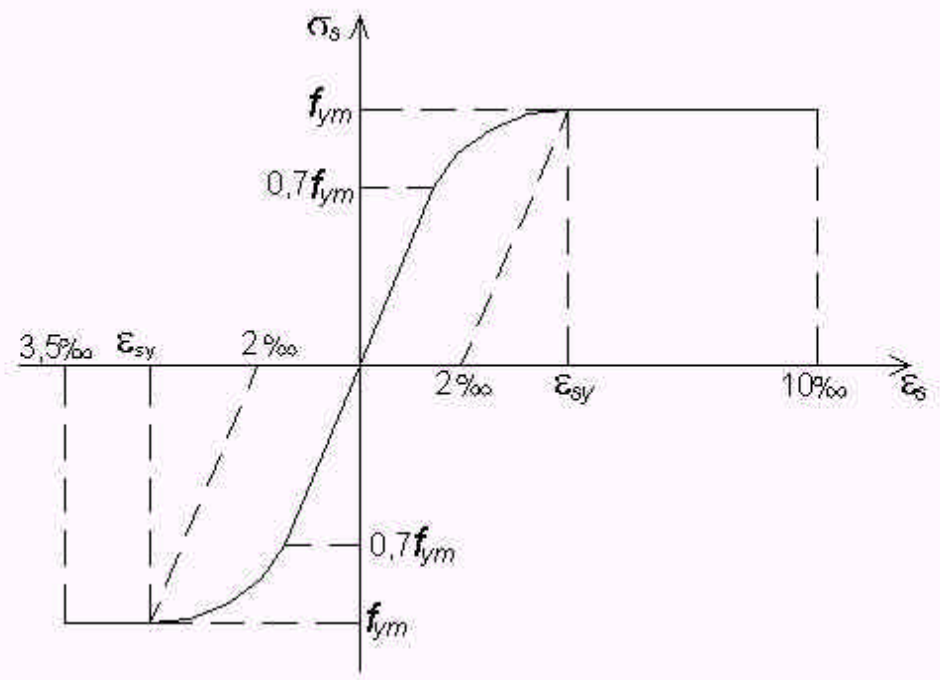

Fig. A.3 Diagrama tensão-deformação do aço classe B

O valor da tensão no aço $\left(\sigma_{s}\right)$ menor que $0,7 f_{y m}$ é calculado mediante a equação (01), para a tensão compreendida entre $0,7 f_{y m}$ e $f_{y m}$ esta pode ser obtida pela equação: 


$$
\sigma_{s}=\frac{f_{y m}}{2}\left[1,4-\frac{45 f_{y m}}{E_{s}}+\sqrt{\left(\frac{45 f_{y m}}{E_{s}}-1,4\right)^{2}-4\left(0,49-45 \varepsilon_{s y}\right)}\right]
$$

Agora, para o cálculo da deformação em função da tensão tem-se:

$$
\varepsilon_{s}=\frac{\sigma_{s}}{E_{s}}+\frac{1}{45}\left(\frac{\sigma_{s}}{f_{y m}}-0,7\right)^{2}
$$

$$
\text { Aço classe B: } \varepsilon_{s y}=\frac{f_{y m}}{E_{s}}+2 \%
$$

\section{A.2 - MOMENTO DE ESCOAMENTO OU PLASTIFICAÇÃO E CURVATURAS}

A princípio, em função da seção transversal, da resistência dos materiais constituintes e da taxa ou localização da armadura, não se sabe se ocorre o escoamento da armadura ou a plastificação do concreto. Para este estudo tem-se dois tipos de seção transversal, a retangular e a com seção "T". A seguir apresenta-se as equações de equilíbrio utilizadas na determinação do momento e também da curvatura.

\section{a) Seção Retangular}

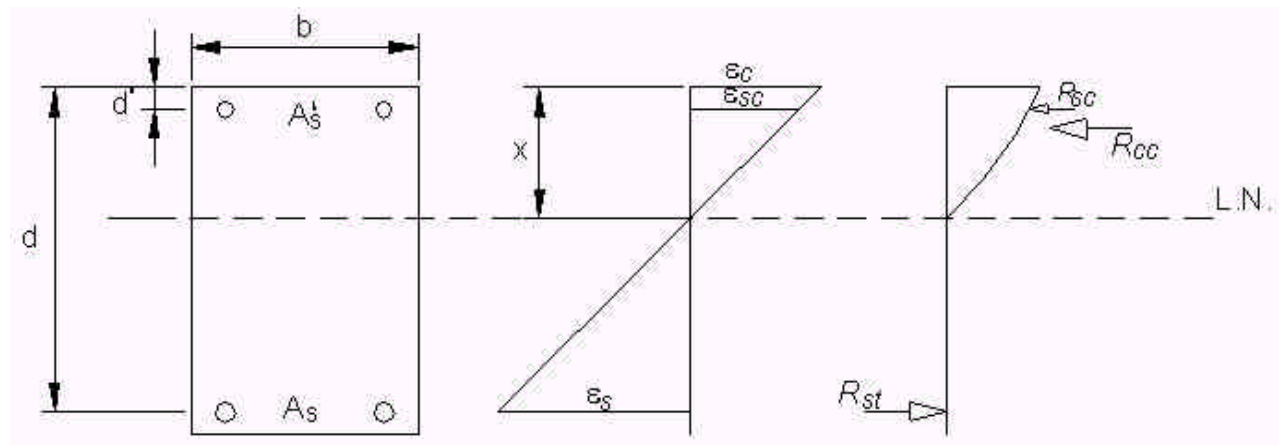

Fig. A.4 Escoamento ou plastificação - seção retangular 

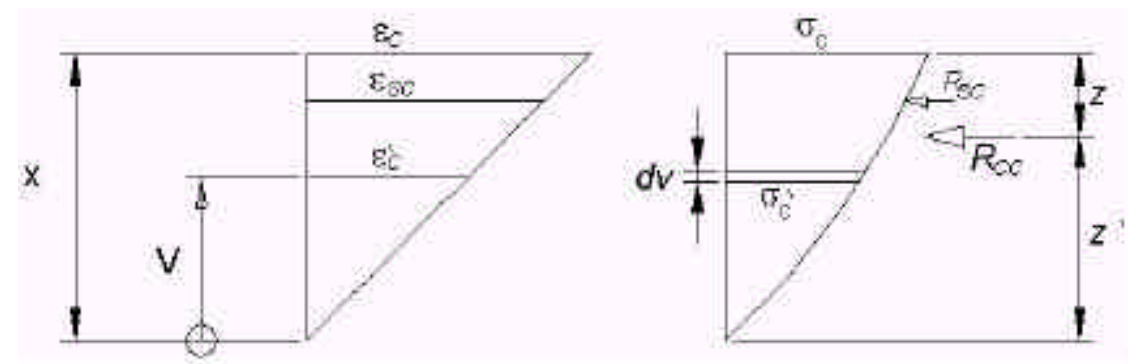

Fig. A.5 Localização da posição de $R_{c c}$

O momento de escoamento ou plastificação $\left(M_{y}\right)$ é calculado fazendo-se a equação de equilíbrio:

$$
\begin{aligned}
& R_{c c}+R_{s c}-R_{s t}=0 \\
& M_{y}=R_{c c}\left(d-z_{G}\right)+R_{s c}\left(d-d^{\prime}\right)
\end{aligned}
$$

sendo, $\quad R_{s t}=A_{s} \sigma_{s} \quad ; \quad R_{s c}=A_{s} \sigma_{s c}$

$R_{c c}$ - Resultante do concreto comprimido

$R_{s c}$ - Resultante da armadura comprimida

$R_{s t}$ - Resultante da armadura tracionada

$z_{G}$ - Localização do centro de gravidade do concreto comprimido

$A_{s}$ - Área de aço tracionada

$A_{s}$ ' - Área de aço comprimida

$\sigma_{s c}$ - Tensão na armadura comprimida

\section{b) Seção "T"}

Para o cálculo da seção "T", de acordo com a figura A.7 calcula-se como uma seção retangular de largura $b$ descontando as áreas sem concreto. 
Denomina-se $R_{c c f}$ a resultante que será descontada e $z_{G f}$ a posição do centro de gravidade da atuação de $R_{c c f}$.

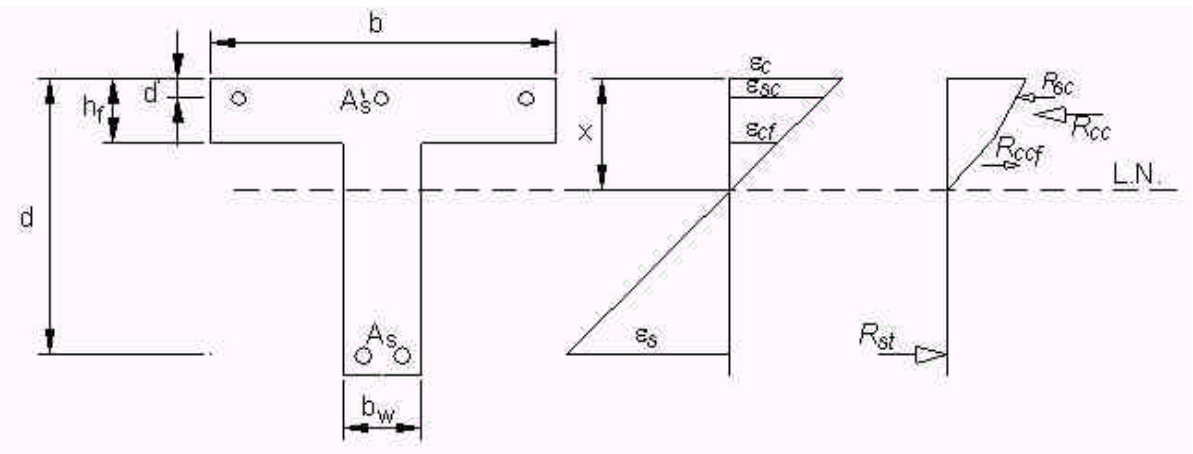

Fig. A.6 Escoamento ou plastificação - seção "T"

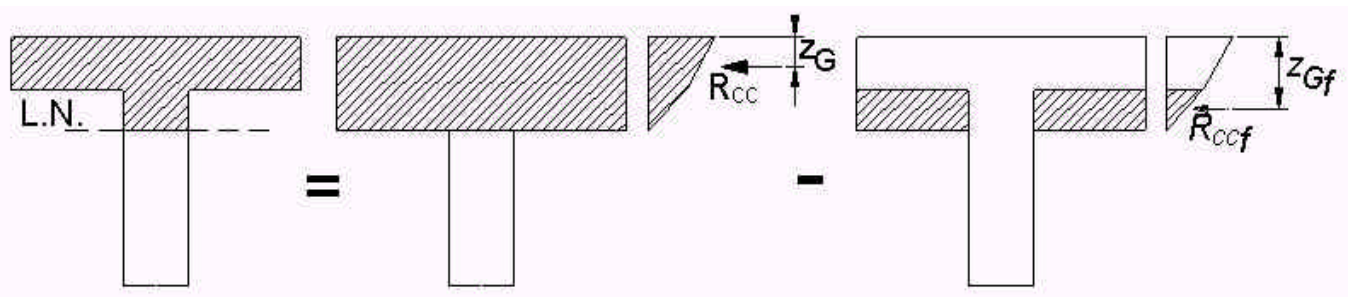

Fig.A.7 Determinação da resultante do concreto para seção "T"

Fazendo-se a equação de equilíbrio:

$$
\begin{aligned}
& R_{c c}+R_{s c}-R_{c c f}-R_{s t}=0 \\
& M_{y}=R_{c c}\left(d-z_{G}\right)+R_{s c}\left(d-d^{\prime}\right)-R_{c c f}\left(d-z_{G f}\right)
\end{aligned}
$$

\section{A.2.1 - ESCOAMENTO DO AÇO}

\section{a) Seção retangular}


Como tem-se o escoamento do aço, a tensão no aço tracionado $\sigma_{s y}$ correspondente a deformação específica ou convencional $\varepsilon_{s y}$ é igual a $f_{y m}$.

A critério do usuário, pode-se definir a tensão de início de escoamento do aço entre $0,7 f_{y m}$ e 1,0 $f_{y m}$ para o aço classe B.

A deformação do concreto $\left(\varepsilon_{c}\right)$ e do aço comprimido $\left(\varepsilon_{s c}\right)$ pode ser obtida de acordo com a compatibilidade de deformações:

$$
\frac{\varepsilon_{c}}{x}=\frac{\varepsilon_{s y}}{d-x}=\frac{\varepsilon_{s c}}{x-d^{\prime}}
$$

De acordo com a figura A.5:

$$
\begin{aligned}
& \varepsilon_{c}^{\prime}=\varepsilon_{c} \frac{v}{x} \quad ; \quad R_{c c}=b \int_{0}^{x} \sigma_{c}^{\prime} d v \\
& \sigma_{c}^{\prime}=f_{c m}\left(\varepsilon_{c}^{\prime}-\frac{\varepsilon_{c}^{\prime 2}}{4}\right)=f_{c m}\left(\varepsilon_{c} \frac{v}{x}-\frac{\varepsilon_{c}^{2} v^{2}}{4 x^{2}}\right) \\
& \text { obtendo, } \quad R_{c c}=b \cdot f_{c m}\left(\frac{\varepsilon_{c} x}{2}-\frac{\varepsilon_{c}^{2} x}{12}\right)
\end{aligned}
$$

Procuremos o centro de gravidade da área vista na figura A.5, de modo a localizar a posição de $R_{c c}$.

$$
\begin{aligned}
& \text { area. } z_{G}^{\prime}=\int_{0}^{x} \sigma_{c}^{\prime} v d v \quad ; \quad \text { area }=f_{c m}\left(\frac{\varepsilon_{c} x}{2}-\frac{\varepsilon_{c}^{2} x}{12}\right) ; \quad z_{G}=x-z_{G}^{\prime} \\
& \text { resultando, } \quad z_{G}=x-\frac{x\left(16-3 \varepsilon_{c}\right)}{24-4 \varepsilon_{c}}
\end{aligned}
$$




\section{b) Seção "T"}

Analogamente à seção retangular temos para $0 \quad R_{c c}$ e $Z_{G}$ as equações 02 e 03 respectivamente. Para o $R_{c c f}$ e $z_{G f}$.

$$
\begin{aligned}
& R_{c c f}=\left(b-b_{w}\right) \int_{0}^{x-h_{f}} f_{c m}\left(\varepsilon_{c} \frac{v}{x}-\frac{\varepsilon_{c}^{2} v^{2}}{4 x^{2}}\right) d v \quad \text { resultando, } \\
& R_{c c f}=\left(b-b_{w}\right) f_{c m}\left(\frac{\varepsilon_{c}\left(x-h_{f}\right)^{2}}{2 x}-\frac{\varepsilon_{c}^{2}\left(x-h_{f}\right)^{3}}{12 x^{2}}\right) \\
& \text { area }_{f} \cdot z_{G f}^{\prime}=\int_{0}^{x-h_{f}} \sigma_{c}^{\prime} v d v ; \quad \text { area }_{f}=f_{c m}\left(\frac{\varepsilon_{c}\left(x-h_{f}\right)^{2}}{2 x}-\frac{\varepsilon_{c}^{2}\left(x-h_{f}\right)^{3}}{12 x^{2}}\right)
\end{aligned}
$$

sendo $z_{G f}=x-z_{G f}^{\prime}$,

$$
z_{G f}=x-\frac{\frac{\varepsilon_{c}\left(x-h_{f}\right)^{3}}{3 x}-\frac{\varepsilon_{c}^{2}\left(x-h_{f}\right)^{4}}{16 x^{2}}}{\frac{\varepsilon_{c}\left(x-h_{f}\right)^{2}}{2 x}-\frac{\varepsilon_{c}^{2}\left(x-h_{f}\right)^{3}}{12 x^{2}}}
$$

Em função do valor da posição da linha neutra $x$, a curvatura $\left(1 / r_{y}\right)$ devida a atuação do momento que causa o escoamento da armadura é:

$$
\frac{1}{r_{y}}=\frac{\varepsilon_{s y}}{d-x}
$$




\section{A.2.2 - PLASTIFICAÇÃO DO CONCRETO}

A determinação do momento de plastificação do concreto pode ser feita aqui, em função da deformação do mesmo. De acordo com o gráfico da figura A.1 observa-se que para valores acima de $2 \%$ o concreto já se encontra no patamar de plastificação, ao adotar este valor como referente ao início do escoamento estar-se-à desconsiderando a perda de rigidez que ocorre para valores de tensão a partir de 0,5 $f_{c m}$. Devido a isto, a deformação que causa o início de plastificação do concreto será variável de acordo com a escolha pessoal, sendo que com isto pode-se analisar os resultados com a consideração de deformações diferentes. Portanto, a tensão no concreto $\sigma_{c}$ é correspondente a deformação escolhida para a plastificação $\varepsilon_{c p}$. A deformação no aço tracionado e comprimido é obtida de acordo com a compatibilidade de deformações:

$$
\frac{\varepsilon_{c p}}{x}=\frac{\varepsilon_{s}}{d-x}=\frac{\varepsilon_{s c}}{x-d^{\prime}}
$$

\section{a) Seção Retangular}

Analogamente ao escoamento do aço obtemos as equações:

$$
\begin{aligned}
& R_{c c}=b \cdot f_{c m}\left(\frac{\varepsilon_{c p} x}{2}-\frac{\varepsilon_{c p}^{2} x}{12}\right) \\
& z_{G}=x-\frac{x\left(16-3 \varepsilon_{c p}\right)}{24-4 \varepsilon_{c p}}
\end{aligned}
$$


b) Seção "T"

Do mesmo modo que a seção retangular tem-se para o $R_{c c}$ e $z_{G}$ as equações 04 e 05 respectivamente. Analogamente, para $R_{c c f}$ e $z_{G f}$ :

$$
\begin{gathered}
R_{c c f}=\left(b-b_{w}\right) f_{c m}\left(\frac{\varepsilon_{c p}\left(x-h_{f}\right)^{2}}{2 x}-\frac{\varepsilon_{c p}^{2}\left(x-h_{f}\right)^{3}}{12 x^{2}}\right) \\
z_{G f}=x-\frac{\frac{\varepsilon_{c p}\left(x-h_{f}\right)^{3}}{3 x}-\frac{\varepsilon_{c p}^{2}\left(x-h_{f}\right)^{4}}{16 x^{2}}}{\frac{\varepsilon_{c p}\left(x-h_{f}\right)^{2}}{2 x}-\frac{\varepsilon_{c p}^{2}\left(x-h_{f}\right)^{3}}{12 x^{2}}}
\end{gathered}
$$

Em função do valor da posição da linha neutra $x$, a curvatura $\left(1 / r_{y}\right)$ devida a atuação do momento que causa a plastificação do concreto é:

$$
\frac{1}{r_{y}}=\frac{\varepsilon_{c p}}{x}
$$

\section{A.3 - MOMENTO E CURVATURA PARA O ESTADO LIMITE ÚLTIMO}

A princípio não sabe-se em que domínio encontra-se um certo elemento estrutural que terá seu comportamento analisado. Neste mesmo programa, em função das resistências do aço e do concreto, das características geométricas da seção transversal e da área de aço, calculase o domínio que satisfaz as equações de equilíbrio. Calcula-se com isso o momento último da seção e a curvatura.

Os limites da posição da Linha Neutra $x_{\text {lim }}$ para cada domínio são função da altura útil ( $d$ ) e para o limite do domínio 3 é função também da deformação específica ou convencional correspondente ao escoamento do aço $\varepsilon_{s y}$. Os limites são: 


$$
\begin{aligned}
& x_{2 a, \lim }=0,1667 . d-\text { limite entre o domínio } 2 \mathrm{a} \text { e } 2 \mathrm{~b} \\
& x_{2 b, \lim }=0,259 . d \quad-\text { limite entre o domínio } 2 \mathrm{~b} \text { e } 3 \\
& x_{3, \lim }=3,5 d /\left(3,5+\varepsilon_{s y}\right) \quad \text { - limite entre o domínio } 3 \text { e } 4
\end{aligned}
$$

De modo análogo ao visto no momento de escoamento e plastificação, tem-se duas seções transversais, a seção retangular e seção "T". As equações de equilíbrio e de determinação dos momentos é também semelhantes. Serão indicadas para cada domínio as resultantes, o momento e curvatura último.

O momento último para a seção retangular e para a seção "T" é calculado de acordo com as equações a seguir:

$$
\begin{aligned}
& \text { seção retangular }-M_{u}=R_{c c}\left(d-z_{G}\right)+R_{s c}\left(d-d^{\prime}\right) \\
& \text { seção "T" - } M_{u}=R_{c c}\left(d-z_{G}\right)+R_{s c}\left(d-d^{\prime}\right)-R_{c c f}\left(d-z_{G f}\right)
\end{aligned}
$$

\section{A.3.1 - SUB-DOMÍNIO 2a ( $\varepsilon_{c} \leq 2 \%$; $\varepsilon_{s}=10 \%$ )}

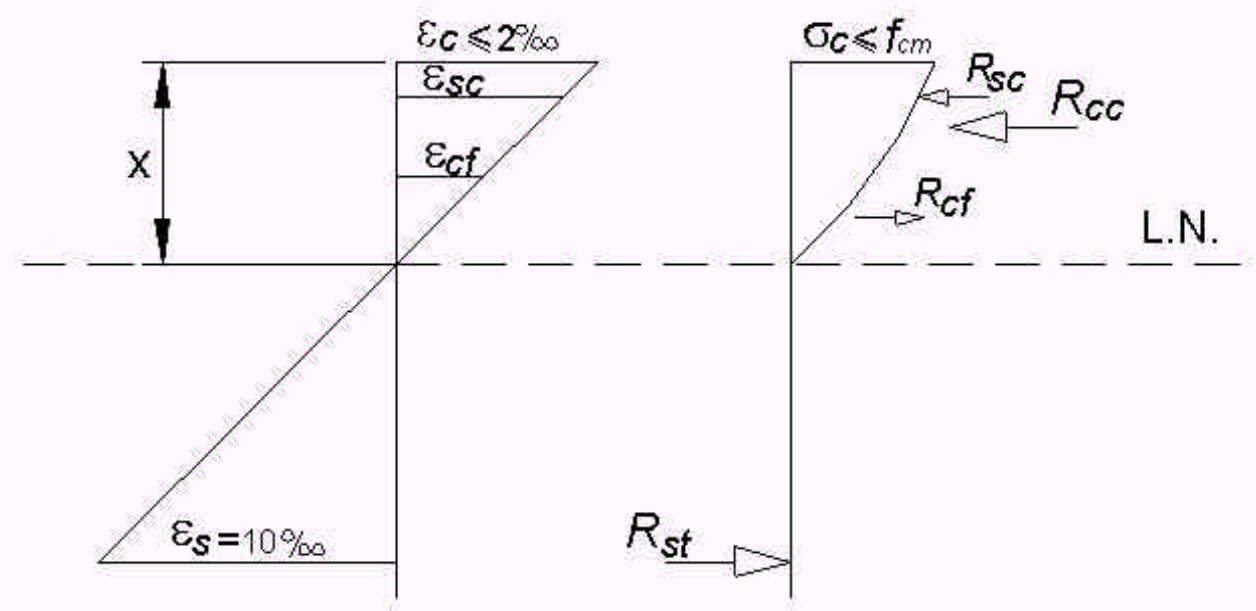

Fig.A.8 Sub-domínio $2^{a}$ 


$$
\begin{array}{rlrl}
\text { deformações: } & \varepsilon_{s}=10 \% 0 & \varepsilon_{c}=\frac{x \cdot 10 \% 0}{d-x} \\
\varepsilon_{s c}=\frac{\left(x-d^{\prime}\right) \cdot 10 \% 0}{d-x} & \varepsilon_{c f}=\frac{(x-h f) \cdot 10 \%}{d-x}
\end{array}
$$

\section{a) Seção retangular}

$$
\begin{aligned}
& R_{c c}=b \cdot f_{c m}\left(\frac{\varepsilon_{c} x}{2}-\frac{\varepsilon_{c}^{2} x}{12}\right) \\
& z_{G}=x-\frac{x\left(16-3 \varepsilon_{c}\right)}{24-4 \varepsilon_{c}}
\end{aligned}
$$

\section{b) Seção "T"}

Equações (06) e (07) para $R_{c c}$ e $z_{G}$.

$$
\begin{gathered}
R_{c c f}=\left(b-b_{w}\right) f_{c m}\left(\frac{\varepsilon_{c}\left(x-h_{f}\right)^{2}}{2 x}-\frac{\varepsilon_{c}^{2}\left(x-h_{f}\right)^{3}}{12 x^{2}}\right) \\
z_{G f}=x-\frac{\frac{\varepsilon_{c}\left(x-h_{f}\right)^{3}}{3 x}-\frac{\varepsilon_{c}^{2}\left(x-h_{f}\right)^{4}}{16 x^{2}}}{\frac{\varepsilon_{c}\left(x-h_{f}\right)^{2}}{2 x}-\frac{\varepsilon_{c}^{2}\left(x-h_{f}\right)^{3}}{12 x^{2}}}
\end{gathered}
$$

Em função do valor da posição da linha neutra $x$, a curvatura $\left(1 / r_{u}\right)$ no sub-domínio 2a é:

$$
\frac{1}{r_{u}}=\frac{10 \% 0}{d-x}
$$


A.3.2 - SUB-DOMÍNIO $2 b\left(2 \% \circ<\varepsilon_{c}<3,5 \%\right.$; $\varepsilon_{s}=10 \%$ o

$$
\begin{array}{lll}
\text { deformações: } & \varepsilon_{s}=10 \% \text { oo } & \varepsilon_{c}=\frac{x \cdot 10 \% 0}{d-x} \\
\varepsilon_{s c}=\frac{\left(x-d^{\prime}\right) \cdot 10 \% 0}{d-x} & \varepsilon_{c f}=\frac{(x-h f) \cdot 10 \% 0}{d-x}
\end{array}
$$

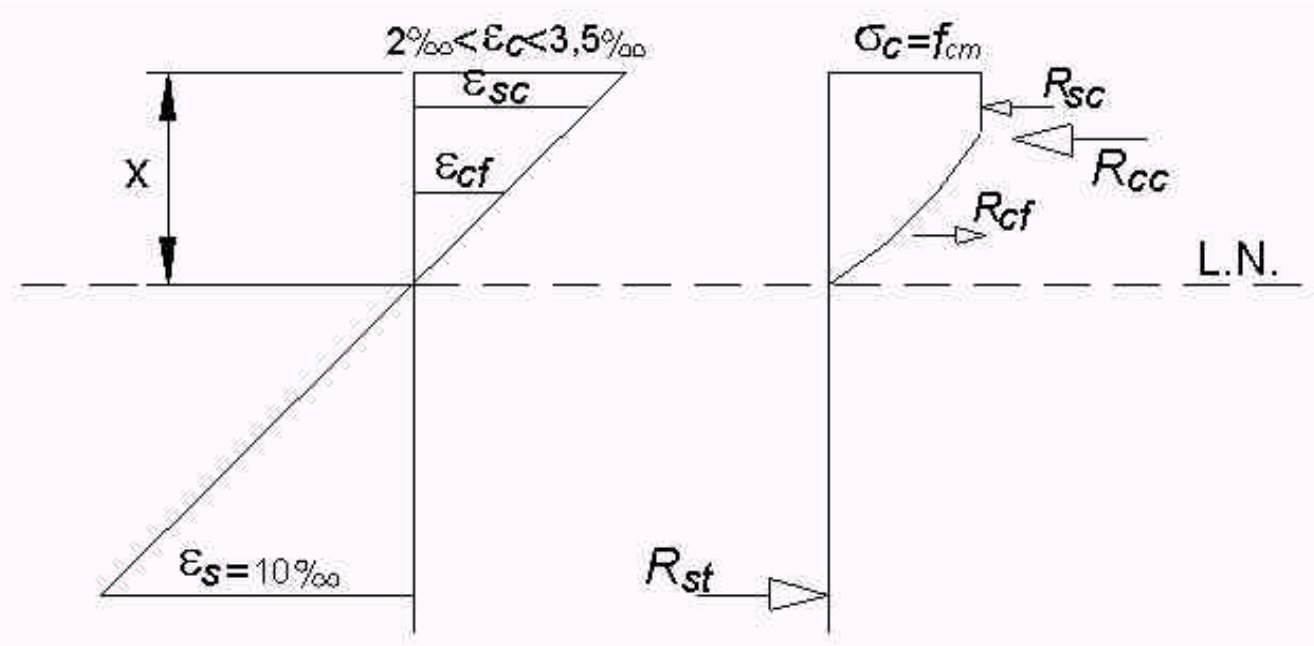

Fig.A.9 Sub-domínio $2 b$

a) Seção retangular
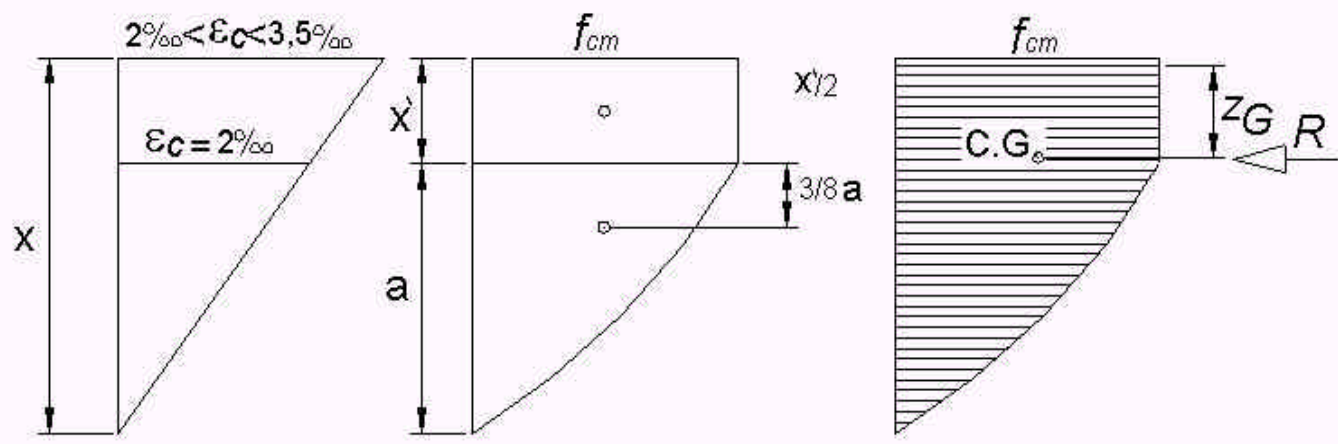

Fig.A.10 Localização da posição de $R_{c c}$ 


$$
\begin{aligned}
& x^{\prime}=(6 x-d) / 5 ; \quad a=(d-x) / 5 \\
& R_{c c}=b \cdot f_{c m} x^{\prime}+b \frac{2}{3} f_{c m} \cdot a \\
& z_{G}=\left[f_{c m} \frac{b \cdot x^{\prime 2}}{2}+b \cdot f_{c m} \frac{2}{3} a\left(\frac{3}{8} a+x^{\prime}\right)\right] / R_{c c}
\end{aligned}
$$

\section{b) Seção "T"}

$R_{c c}$ e $z_{G}$, equações (10) e (11)

Para a seção "T" duas situações podem ocorrer:

a) $\varepsilon_{\text {cf }} \leq 2 \%$

$R_{c c f}$ e $z_{G f}$, equações (08) e (09)

b) $\varepsilon_{\text {cf }}>2 \%$
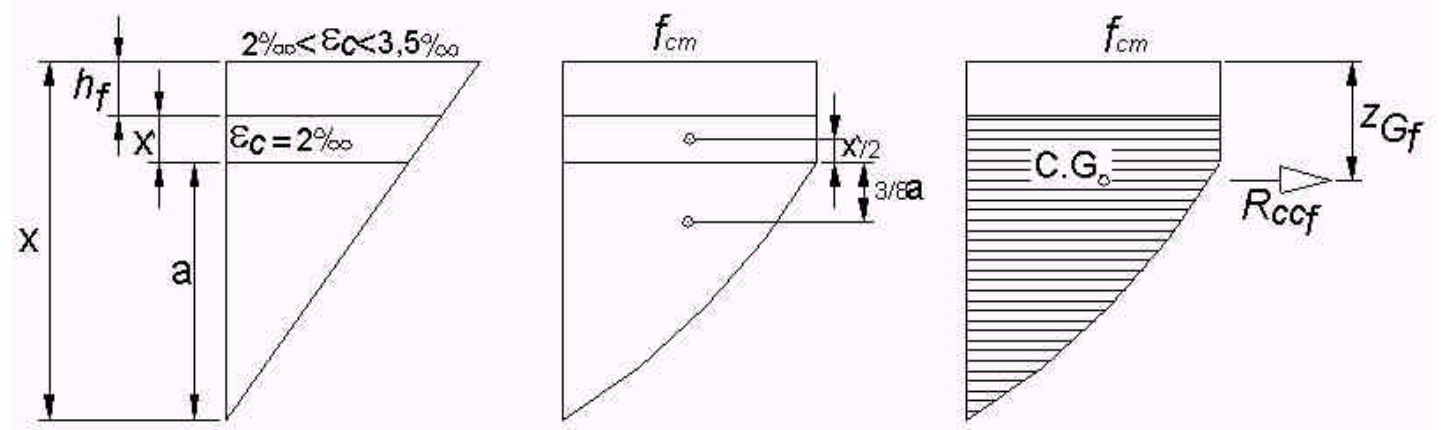

Fig.A.11 Localização da posição de $R_{c c f}$

$R_{c c f}$ e $z_{G f}$, equações:

$$
x^{\prime}=\left(6 x-d-5 h_{f}\right) / 5 \quad ; \quad a=(d-x) / 5
$$




$$
\begin{aligned}
& R_{c c f}=\left(b-b_{w}\right) f_{c m} x^{\prime}+\left(b-b_{w}\right) \frac{2}{3} f_{c m} \cdot a \\
& z_{G f}=\left[f_{c m} \frac{\left(b-b_{w}\right) x^{\prime 2}}{2}+\left(b-b_{w}\right) f_{c m} \frac{2}{3} a\left(\frac{3}{8} a+x^{\prime}+h_{f}\right)\right] / R_{c c f}
\end{aligned}
$$

A curvatura $\left(1 / r_{u}\right)$ no sub-domínio $2 b$ é:

$$
\frac{1}{r_{u}}=\frac{10 \% 0}{d-x}
$$

A.3.3 - DOMÍNIO 3 ( $\varepsilon_{\mathrm{c}}=3,5 \%$; $\varepsilon_{\mathrm{sy}} \leq \varepsilon_{\mathrm{s}} \leq 10 \%$ o $)$

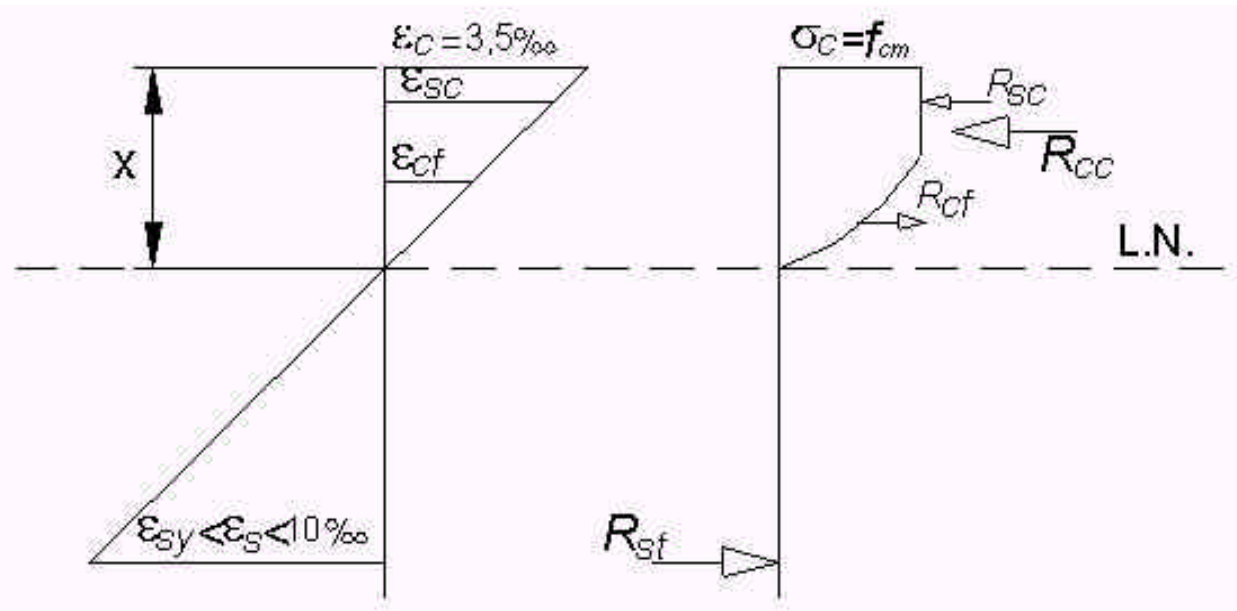

Fig.A.12 Domínio 3

deformações:

$$
\begin{array}{cc}
\varepsilon_{c}=3,5 \% o & \varepsilon_{s}=\frac{3,5 \% 0(d-x)}{x} \\
\varepsilon_{s c}=\frac{3,5 \% 0\left(x-d^{\prime}\right)}{x} & \varepsilon_{c f}=\frac{3,5 \%\left(x-h_{f}\right)}{x}
\end{array}
$$




\section{a) Seção retangular}
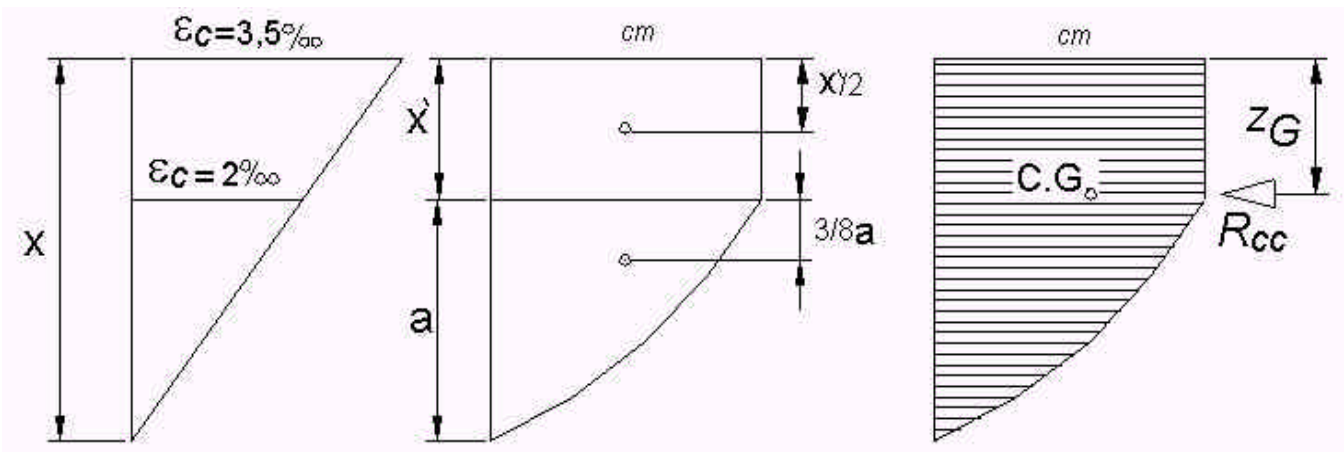

Fig.A.13 Localização da posição de $R_{c c}$

$$
\begin{aligned}
& \qquad a=\frac{4}{7} x \quad ; \quad x^{\prime}=\frac{3}{7} x \\
& R_{c c}=b \cdot f_{c m} x^{\prime}+b \frac{2}{3} f_{c m} a \\
& z_{G}=\left[b \cdot f_{c m} \frac{x^{\prime 2}}{2}+b \cdot f c m \frac{2}{3} a\left(x^{\prime}+\frac{3}{8} a\right)\right] / R_{c c}
\end{aligned}
$$

b) Seção "T"

$R_{c c}$ e $z_{G}$, equações (14) e (15)

b.1) $\varepsilon_{\mathrm{cf}} \leq 2 \%$

$R_{c c f}$ e $z_{G f}$, equações (08) e (09)

b.2) $\varepsilon_{\mathrm{cf}}>2 \%$ 
ANEXO A

165
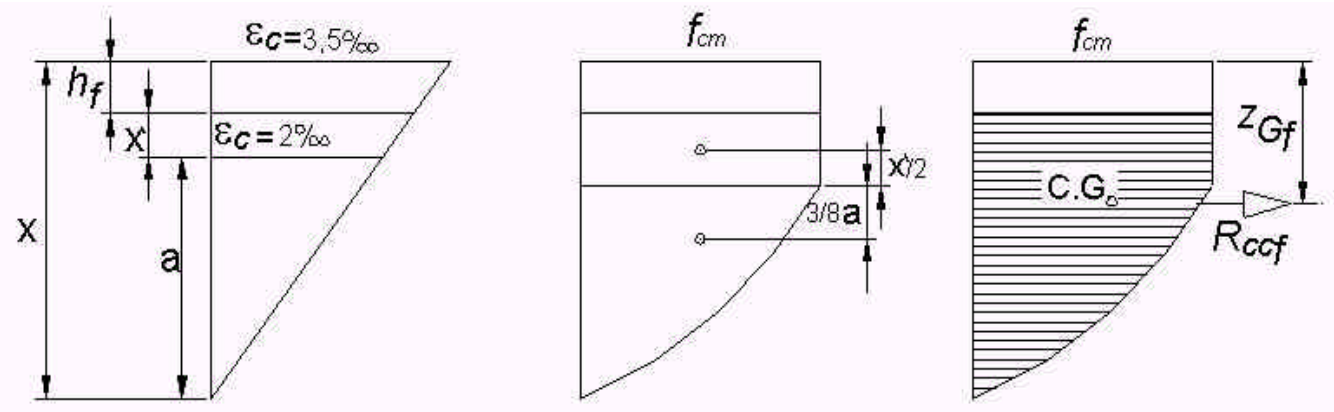

Fig.A.14 Localização da posição de $R_{c c f}$

$a=\frac{4}{7} x \quad ; \quad x^{\prime}=\frac{3}{7} x-h_{f}$

$R_{c c f} \mathrm{e} z_{G f}$, equações (12) e (13)

A curvatura $\left(1 / r_{u}\right)$ no domínio 3 é:

$$
\frac{1}{r_{u}}=\frac{3,5 \% 0}{x}
$$

A.3.4 - DOMÍNIO $4\left(\varepsilon_{\mathrm{c}}=3,5 \%\right.$; $\left.\varepsilon_{\mathrm{s}}<\varepsilon_{\mathrm{sy}}\right)$

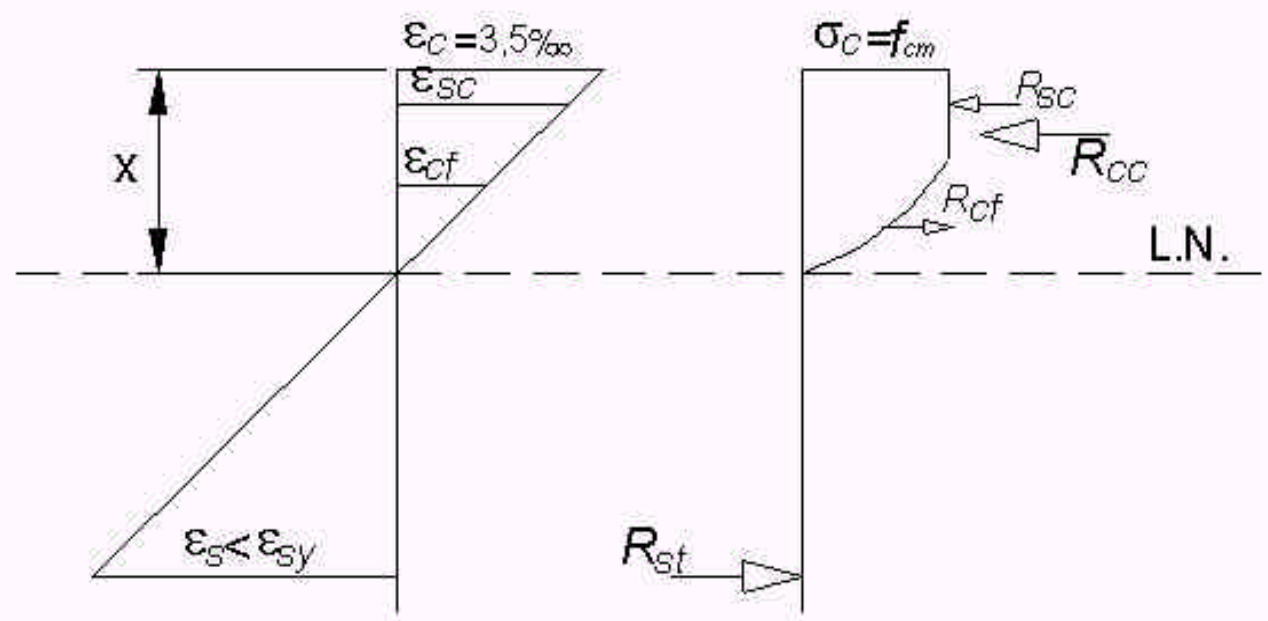

Fig.A.15 Domínio 4 


$$
\begin{array}{lll}
\text { deformações: } & \varepsilon_{c}=3,5 \% \text { oo } & \varepsilon_{s}=\frac{3,5 \%(d-x)}{x} \\
\varepsilon_{s c}=\frac{3,5 \% 00\left(x-d^{\prime}\right)}{x} & \varepsilon_{c f}=\frac{3,5 \%\left(x-h_{f}\right)}{x}
\end{array}
$$

\section{a) Seção Retangular}

$R_{c C}$ e $z_{G}$, equações (14) e (15)

\section{b) Seção " $T$ "}

$R_{c c}$ e $z_{G}$, equações (14) e (15)

b.1) $\varepsilon_{\mathrm{cf}} \leq 2 \% \mathrm{o}$

$R_{c c f}$ e $z_{G f}$, equações (08) e (09)

b.2) $\varepsilon_{\mathrm{cf}}>2 \%$

$$
a=\frac{4}{7} x \quad ; \quad x^{\prime}=\frac{3}{7} x-h_{f}
$$

$R_{c c f}$ e $z_{G f}$, equações (12) e (13)

Em função do valor da posição da linha neutra $x$, a curvatura $\left(1 / r_{u}\right)$ no domínio 4 é:

$$
\frac{1}{r_{u}}=\frac{3,5 \% 0}{x}
$$




\section{ANEXO B}

\section{DETERMINAÇÃO DA RIGIDEZ À FLEXÃO DO ESTÁDIO II, MEDIANTE A HOMOGENEIZAÇÃO DA SEÇÃO E DA RELAÇÃO MOMENTO-CURVATURA}

Neste exemplo numérico deseja-se comparar os valores de rigidez à flexão para o estádio II, de acordo com a homogeneização da seção e em função da relação momento curvatura obtida através das equações de equilíbrio.

Apresenta-se a seguir na figura B.1 a seção transversal de uma viga retangular e de uma nervura formada pela vigota pré-moldada e concreto de capeamento.

As características gerais destes elementos são:

$$
\begin{aligned}
& f_{c m}=20 \mathrm{MPa} ; \quad f_{c t m}=2,2 \mathrm{MPa}(\mathrm{CEB}-90) \\
& E_{c}=27088 \mathrm{MPa} \text { e } E_{c s}=23025 \mathrm{MPa} \quad(\mathrm{CEB}-90) \\
& \alpha=210000 \mathrm{MPa} / 27088 \mathrm{MPa}=7,8 \\
& f_{y m}=500 \mathrm{MPa}(\mathrm{CA}-50 \mathrm{~A})-\text { viga } \\
& f_{y m}=600 \mathrm{MPa}(\mathrm{CA}-60 \mathrm{~B})-\text { nervura }
\end{aligned}
$$



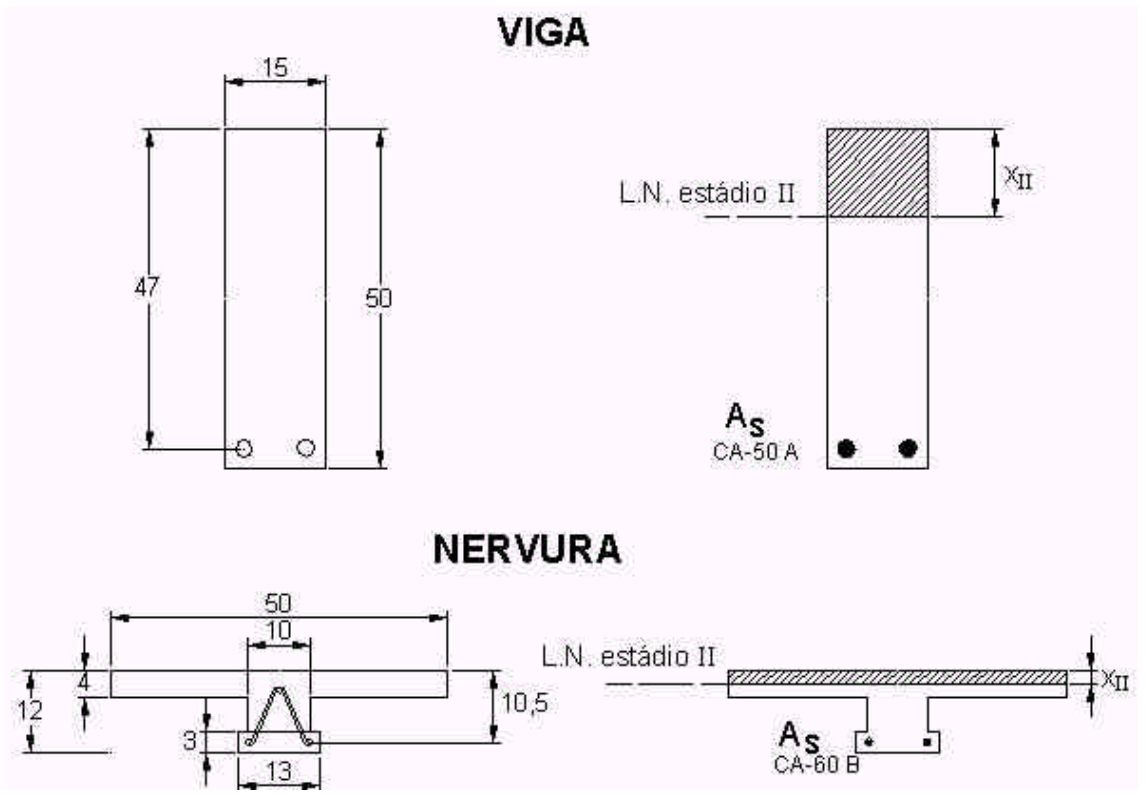

Fig.B.1 Seção transversal da viga e da nervura

a) Viga:

Adotam-se dois valores de deformação para considerar o início de plastificação do concreto $\left(\varepsilon_{c p}\right)$.

$$
\varepsilon_{c p}=1,5 \% \text { e } 2 \%
$$

b) Nervura:

Considera-se o início de plastificação do concreto com a deformação igual a $1,5 \%$, sendo o início de escoamento do aço os valores de tensão $\left(\sigma_{\text {sy }}\right)$ igual a:

$$
\sigma_{s y}=0,7 f_{y m}, 0,85 f_{y m} \text { e } 1,0 f_{y m} .
$$

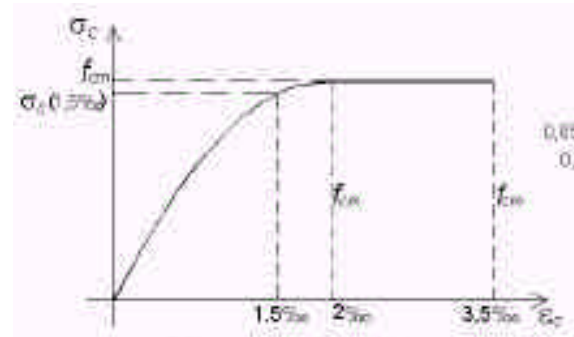

diagrama ten concreto

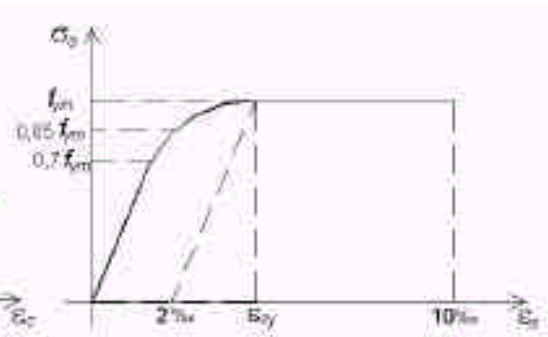

diagrama tensăo $x$ deforma ço açO CA-6DB

Fig.B.2 Diagrama tensão $x$ deformação do concreto e do aço 
Utilizando-se o programa RIGIDEZ, desenvolvido em linguagem FORTRAN, montam-se as tabelas B.1 e B.2, referentes à hipótese a) e b) respectivamente, onde se pode analisar a influência da variação da área de aço (taxa de armadura) e do valor do início de plastificação do concreto ou escoamento do aço. Compara-se a rigidez obtida pela homogeneização da seção e pela curvatura, sendo:

$$
\operatorname{RIGIDEZ}(1)=E_{c s} \mathrm{I}_{\mathrm{II}} \quad ; \quad \operatorname{RIGIDEZ}(2)=\frac{M_{y}}{\frac{1}{r_{y}}}
$$

De acordo com a figura B.3, observa-se que a diferença entre os métodos utilizados, para este caso, é maior para altas taxas de armadura da viga. Com a consideração do início de plastificação do concreto igual a 1,5 $\%$, tem-se uma melhor aproximação com a rigidez calculada pela homogeneização da seção.

Para a nervura, aço classe B, figura B.4, tem-se uma melhor aproximação com a rigidez calculada pela homogeneização da seção a tensão de escoamento compreendida entre a 0,7 e 0,85 $f_{y m}$.

Define-se que o aço entra em escoamento ou o concreto entra em plastificação a partir do estádio II puro, por isso, de acordo com a definição, o valor da linha neutra calculada para o estádio II deve ser o mesmo para o calculado pelo $M_{y}$. Com o cálculo da rigidez em função das curvaturas esta igualdade ocorre.

Para as análises a seguir, tem-se, portanto dois caminhos. Com isso, para cada modelo teórico mostra-se os dois processos e analisa-se a compatibilidade esperada entre ambos.

Para a entrada da rigidez no estádio II, nos "macros" do ANSYS ${ }^{\circledR}$, para a análise não-linear de uma estrutura necessita-se dos valores de $E_{c S} \mathrm{e}$ $\mathrm{I}_{\text {II. }}$ Para o processo da homogeneização isto é direto, para o segundo, divide-se a RIGIDEZ(2) por $E_{c s}$ e tem-se um III equivalente: 


$$
\left.I_{\mathrm{II}} \text { (equivalente }\right)=\frac{M_{y}}{\frac{1}{r_{y}} E_{c s}}=\frac{R \operatorname{IGIDEZ}(2)}{E_{c s}}
$$

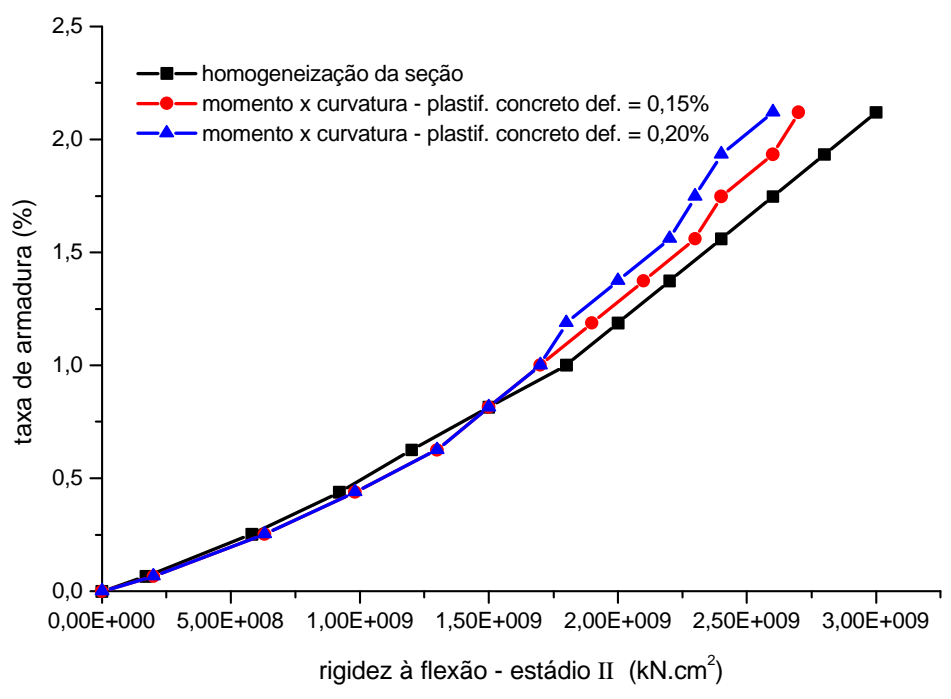

Fig. B.3 Taxa de armadura x rigidez à flexão viga com aço CA-50

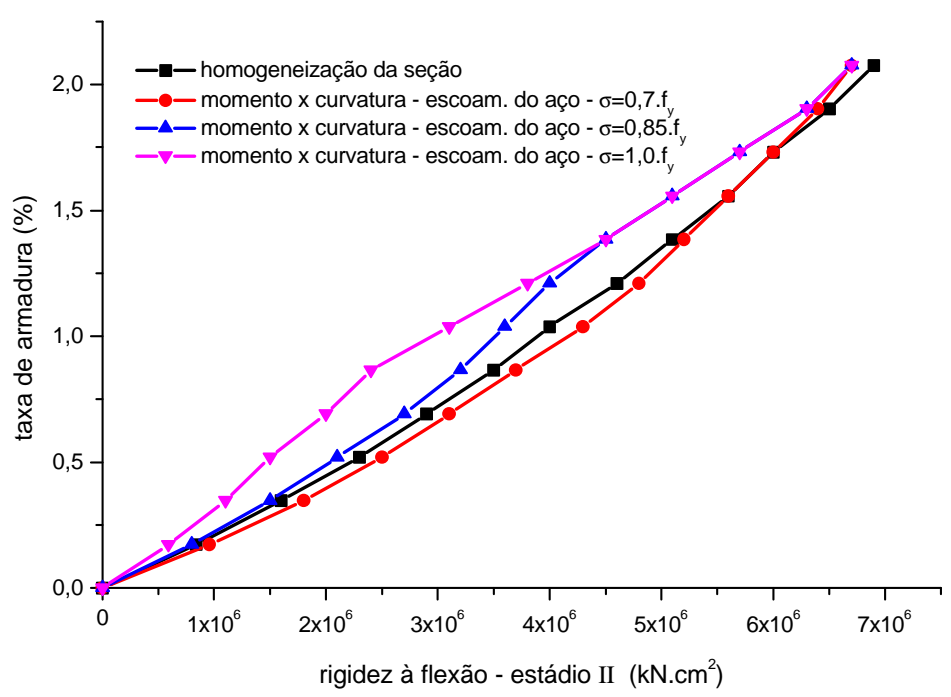

Fig.B.4 Taxa de armadura $x$ rigidez à flexão nervura com aço CA-60 
Tabela B.1 Características geométricas e mecânicas da viga retangular

\begin{tabular}{|c|c|c|c|c|c|c|c|c|c|c|c|c|}
\hline área de aço & 0,50 & 1,90 & 3,30 & 4,70 & 6,10 & 7,50 & 8,90 & 10,30 & 11,70 & 13,10 & 14,50 & 15,90 \\
\hline taxa de armadura (\%) & 0,07 & 0,25 & 0,44 & 0,63 & 0,81 & 1,00 & 1,19 & 1,37 & 1,56 & 1,75 & 1,93 & 2,12 \\
\hline $\mathrm{XI}_{\mathrm{I}}$ & 25,10 & 25,37 & 25,64 & 25,90 & 26,15 & 26,40 & 26,64 & 26,88 & 27,11 & 27,34 & 27,56 & 27,77 \\
\hline II & 157888 & 162397 & 166795 & 171086 & 175274 & 179362 & 183355 & 187254 & 191064 & 194787 & 198427 & 201987 \\
\hline $\mathrm{X}_{\mathrm{II}}$ & 4,69 & 8,70 & 11,10 & 12,91 & 14,38 & 15,64 & 16,74 & 17,71 & 18,59 & 19,39 & 20,13 & 20,81 \\
\hline III & 7497 & 25032 & 40012 & 53362 & 65496 & 76660 & 87021 & 96697 & 105781 & 114344 & 122443 & 130127 \\
\hline $\mathrm{Mr}$ & 2092,4 & 2176,1 & 2259,5 & 2342,6 & 2425,5 & 2508,1 & 2590,5 & 2672,6 & 2754,5 & 2836,2 & 2917,6 & 2998,7 \\
\hline RIGIDEZ (1) estádio II & $1,7 \mathrm{E}+08$ & $5,8 \mathrm{E}+08$ & $9,2 \mathrm{E}+08$ & $1,2 \mathrm{E}+09$ & $1,5 \mathrm{E}+09$ & $1,8 \mathrm{E}+09$ & $2,0 \mathrm{E}+09$ & $2,2 \mathrm{E}+09$ & $2,4 \mathrm{E}+09$ & $2,6 \mathrm{E}+09$ & $2,8 \mathrm{E}+09$ & $3,0 \mathrm{E}+09$ \\
\hline \multicolumn{13}{|c|}{ Início de plastificação do concreto - deformação = 1,5 / 1000} \\
\hline ESCOAM. OU PLASTIF. & ARMAD & ARMAD & ARMAD & ARMAD & ARMAD & CONCR & CONCR & CONCR & CONCR & CONCR & CONCR & CONCR \\
\hline My & 1128,17 & 4122,91 & 6973,42 & 9709,27 & 12340,27 & 13197,62 & 13884,33 & 14471,01 & 14980,81 & 15430,16 & 15829,59 & 16188,77 \\
\hline $1 /$ ry & 0,00006 & 0,00007 & 0,00007 & 0,00008 & 0,00008 & 0,00008 & 0,00007 & 0,00007 & 0,00007 & 0,00006 & 0,00006 & 0,00006 \\
\hline$X_{y}$ & 5,54 & 10,47 & 13,57 & 16,02 & 18,12 & 19,59 & 20,84 & 21,95 & 22,93 & 23,81 & 24,61 & 25,35 \\
\hline TENSAO CONCR. & 0,59 & 1,13 & 1,47 & 1,70 & 1,87 & 1,88 & 1,88 & 1,88 & 1,88 & 1,88 & 1,88 & 1,88 \\
\hline DEF. CONCR. & 0,32 & 0,68 & 0,97 & 1,23 & 1,49 & 1,50 & 1,50 & 1,50 & 1,50 & 1,50 & 1,50 & 1,50 \\
\hline TENSAO As & 50,00 & 50,00 & 50,00 & 50,00 & 50,00 & 44,08 & 39,53 & 35,96 & 33,07 & 30,68 & 28,65 & 26,91 \\
\hline DEF. As & 2,38 & 2,38 & 2,38 & 2,38 & 2,38 & 2,10 & 1,88 & 1,71 & 1,57 & 1,46 & 1,36 & 1,28 \\
\hline RIGIDEZ (2) estádio II & $2,0 \mathrm{E}+08$ & $6,3 \mathrm{E}+08$ & $9,8 \mathrm{E}+08$ & $1,3 \mathrm{E}+09$ & $1,5 \mathrm{E}+09$ & $1,7 \mathrm{E}+09$ & $1,9 \mathrm{E}+09$ & $2,1 \mathrm{E}+09$ & $2,3 \mathrm{E}+09$ & $2,4 \mathrm{E}+09$ & $2,6 \mathrm{E}+09$ & $2,7 \mathrm{E}+09$ \\
\hline \multicolumn{13}{|c|}{ Início de plastificação do concreto - deformação $=2,0 / 1000$} \\
\hline ESCOAM. OU PLASTIF. & ARMAD & ARMAD & ARMAD & ARMAD & ARMAD & ARMAD & CONCR & CONCR & CONCR & CONCR & CONCR & CONCR \\
\hline My & 1128,17 & 4122,91 & 6973,42 & 9709,27 & 12340,27 & 14858,56 & 16884,75 & 17564,28 & 18151,67 & 18666,80 & 19122,65 & 19530,51 \\
\hline $1 /$ ry & 0,00006 & 0,00007 & 0,00007 & 0,00008 & 0,00008 & 0,00009 & 0,00009 & 0,00009 & 0,00008 & 0,00008 & 0,00008 & 0,00008 \\
\hline$X y$ & 5,54 & 10,47 & 13,57 & 16,02 & 18,12 & 20,04 & 21,73 & 22,85 & 23,85 & 24,74 & 25,55 & 26,29 \\
\hline TENSAO CONCR. & 0,59 & 1,13 & 1,47 & 1,70 & 1,87 & 1,97 & 2,00 & 2,00 & 2,00 & 2,00 & 2,00 & 2,00 \\
\hline DEF. CONCR. & 0,32 & 0,68 & 0,97 & 1,23 & 1,49 & 1,77 & 2,00 & 2,00 & 2,00 & 2,00 & 2,00 & 2,00 \\
\hline TENSAO As & 0,00 & 0,00 & 0,00 & 0,00 & 0,00 & 0,00 & 0,00 & 0,00 & 0,00 & 0,00 & 0,00 & 0,00 \\
\hline DEF. As & 2,38 & 2,38 & 2,38 & 2,38 & 2,38 & 2,38 & 2,33 & 2,11 & 1,94 & 1,80 & 1,68 & 1,58 \\
\hline RIGIDEZ (2) estádio II & $2,0 \mathrm{E}+08$ & $6,3 \mathrm{E}+08$ & $9,8 \mathrm{E}+08$ & $1,3 \mathrm{E}+09$ & $1,5 \mathrm{E}+09$ & $1,7 \mathrm{E}+09$ & $1,8 \mathrm{E}+09$ & $2,0 \mathrm{E}+09$ & $2,2 \mathrm{E}+09$ & $2,3 \mathrm{E}+09$ & $2,4 \mathrm{E}+09$ & $2,6 \mathrm{E}+09$ \\
\hline MOM. ÚLTIMO & $\mathrm{DOM} 2 \mathrm{~A}$ & DOM2A & DOM2B & DOM2B & DOM3 & $\mathrm{DOM} 3$ & DOM3 & $\mathrm{DOM} 3$ & $\mathrm{DOM} 3$ & $\mathrm{DOM} 3$ & DOM4 & DOM4 \\
\hline $\mathrm{Mu}$ & 1150,2 & 4265,0 & 7251,1 & 10079,3 & 12741,8 & 15216,2 & 17523,6 & 19662,3 & 21633,2 & 23436,9 & 24323,1 & 24736,7 \\
\hline $1 / \mathrm{ru}$ & 0,00023 & 0,00024 & 0,00026 & 0,00027 & 0,00028 & 0,00023 & 0,00019 & 0,00017 & 0,00015 & 0,00013 & 0,00012 & 0,00012 \\
\hline$\underline{\mathrm{Xu}}$ & 2,87 & 5,84 & 8,09 & 10,28 & 12,56 & 15,44 & 18,32 & 21,21 & 24,09 & 26,97 & 28,50 & 29,24 \\
\hline TENSAO CONCR. & 1,09 & 1,83 & 2,00 & 2,00 & 2,00 & 2,00 & 2,00 & 2,00 & 2,00 & 2,00 & 2,00 & 2,00 \\
\hline DEF. CONCR. & 0,65 & 1,42 & 2,08 & 2,80 & 3,50 & 3,50 & 3,50 & 3,50 & 3,50 & 3,50 & 3,50 & 3,50 \\
\hline TENSAO As & 50,00 & 50,00 & 50,00 & 50,00 & 50,00 & 50,00 & 50,00 & 50,00 & 50,00 & 50,00 & 47,73 & 44,66 \\
\hline DEF. As & 10,00 & 10,00 & 10,00 & 10,00 & 9,60 & 7,15 & 5,48 & 4,26 & 3,33 & 2,60 & 2,27 & 2,13 \\
\hline
\end{tabular}


Tabela B.2 Características geométricas e mecânicas da nervura

\begin{tabular}{|c|c|c|c|c|c|c|c|c|c|c|c|c|}
\hline área de aço & 0,50 & 1,00 & 1,50 & 2,00 & 2,50 & 3,00 & 3,50 & 4,00 & 4,50 & 5,00 & 5,50 & 6,00 \\
\hline taxa de armadura (\%) & 0,17 & 0,35 & 0,52 & 0,69 & 0,87 & 1,04 & 1,21 & 1,38 & 1,56 & 1,73 & 1,90 & 2,08 \\
\hline $\mathrm{X}_{\mathrm{I}}$ & 3,98 & 4,05 & 4,12 & 4,20 & 4,27 & 4,34 & 4,40 & 4,47 & 4,53 & 4,59 & 4,66 & 4,72 \\
\hline II & 3305 & 3448 & 3588 & 3725 & 3858 & 3989 & 4117 & 4242 & 4364 & 4484 & 4601 & 4716 \\
\hline $\mathrm{X}_{\mathrm{II}}$ & 1,20 & 1,66 & 2,00 & 2,27 & 2,50 & 2,70 & 2,88 & 3,05 & 3,20 & 3,34 & 3,47 & 3,60 \\
\hline III & 366 & 686 & 979 & 1252 & 1508 & 1752 & 1983 & 2205 & 2417 & 2620 & 2817 & 3006 \\
\hline $\mathrm{Mr}$ & 108,8 & 114,5 & 120,3 & 126,0 & 131,7 & 137,4 & 143,0 & 148,7 & 154,3 & 159,9 & 165,4 & 171,0 \\
\hline RIGIDEZ (1) estádio II & $8,4 \mathrm{E}+05$ & $1,6 \mathrm{E}+06$ & $2,3 \mathrm{E}+06$ & $2,9 \mathrm{E}+06$ & $3,5 \mathrm{E}+06$ & $4,0 \mathrm{E}+06$ & $4,6 \mathrm{E}+06$ & $5,1 \mathrm{E}+06$ & $5,6 \mathrm{E}+06$ & $6,0 \mathrm{E}+06$ & $6,5 \mathrm{E}+06$ & $6,9 \mathrm{E}+06$ \\
\hline \multicolumn{13}{|c|}{ Início de escoamento do aço - tensão $=0,7$ fy } \\
\hline ESCOAM. OU PLASTIF. & ARMAD & ARMAD & ARMAD & ARMAD & ARMAD & ARMAD & ARMAD & ARMAD & ARMAD & ARMAD & ARMAD & CONCR \\
\hline My & 210,31 & 412,79 & 610,15 & 803,45 & 992,84 & 1179,53 & 1362,96 & 1542,91 & 1720,49 & 1896,41 & 2070,18 & 2230,93 \\
\hline $1 /$ ry & 0,00022 & 0,00023 & 0,00025 & 0,00026 & 0,00027 & 0,00028 & 0,00029 & 0,00030 & 0,00030 & 0,00031 & 0,00032 & 0,00033 \\
\hline Xy & 1,42 & 1,97 & 2,38 & 2,72 & 3,01 & 3,28 & 3,51 & 3,73 & 3,94 & 4,13 & 4,33 & 4,52 \\
\hline TENSAO CONCR. & 0,58 & 0,82 & 1,00 & 1,15 & 1,29 & 1,40 & 1,51 & 1,60 & 1,68 & 1,75 & 1,82 & 1,88 \\
\hline DEF. CONCR. & 0,31 & 0,46 & 0,59 & 0,70 & 0,80 & 0,91 & 1,01 & 1,10 & 1,20 & 1,30 & 1,40 & 1,50 \\
\hline TENSAO As & 42,00 & 42,00 & 42,00 & 42,00 & 42,00 & 42,00 & 42,00 & 42,00 & 42,00 & 42,00 & 42,00 & 41,76 \\
\hline DEF. As & 2,00 & 2,00 & 2,00 & 2,00 & 2,00 & 2,00 & 2,00 & 2,00 & 2,00 & 2,00 & 2,00 & 1,99 \\
\hline RIGIDEZ (2) estádio II & $9,6 \mathrm{E}+05$ & $1,8 \mathrm{E}+06$ & $2,5 \mathrm{E}+06$ & $3,1 \mathrm{E}+06$ & $3,7 \mathrm{E}+06$ & $4,3 \mathrm{E}+06$ & $4,8 \mathrm{E}+06$ & $5,2 \mathrm{E}+06$ & $5,6 \mathrm{E}+06$ & $6,0 \mathrm{E}+06$ & $6,4 \mathrm{E}+06$ & $6,7 \mathrm{E}+06$ \\
\hline
\end{tabular}

\begin{tabular}{|c|c|c|c|c|c|c|c|c|c|c|c|c|}
\hline \multicolumn{13}{|c|}{ Início de escoamento do aço - tensão $=0,85$ fy } \\
\hline ESCOAM. OU PLASTIF. & ARMAD & ARMAD & ARMAD & ARMAD & ARMAD & ARMAD & ARMAD & CONCR & CONCR & CONCR & CONCR & CONCR \\
\hline My & 256,21 & 503,61 & 744,52 & 979,88 & 1210,55 & 1437,08 & 1658,95 & 1863,44 & 1983,67 & 2088,04 & 2171,07 & 2230,93 \\
\hline $1 /$ ry & 0,00032 & 0,00034 & 0,00035 & 0,00037 & 0,00038 & 0,00040 & 0,00041 & 0,00042 & 0,00039 & 0,00036 & 0,00035 & 0,00033 \\
\hline$X y$ & 1,31 & 1,84 & 2,23 & 2,56 & 2,85 & 3,12 & 3,36 & 3,60 & 3,88 & 4,12 & 4,34 & 4,52 \\
\hline TENSAO CONCR. & 0,75 & 1,05 & 1,27 & 1,44 & 1,59 & 1,71 & 1,81 & 1,88 & 1,88 & 1,88 & 1,88 & 1,88 \\
\hline DEF. CONCR. & 0,42 & 0,62 & 0,79 & 0,95 & 1,09 & 1,24 & 1,38 & 1,50 & 1,50 & 1,50 & 1,50 & 1,50 \\
\hline TENSAO As & 51,00 & 51,00 & 51,00 & 51,00 & 51,00 & 51,00 & 51,00 & 50,65 & 48,45 & 46,32 & 44,11 & 41,76 \\
\hline DEF. As & 2,93 & 2,93 & 2,93 & 2,93 & 2,93 & 2,93 & 2,93 & 2,87 & 2,56 & 2,32 & 2,13 & 1,99 \\
\hline RIGIDEZ (2) estádio II & $8,0 \mathrm{E}+05$ & $1,5 \mathrm{E}+06$ & $2,1 \mathrm{E}+06$ & $2,7 \mathrm{E}+06$ & $3,2 \mathrm{E}+06$ & $3,6 \mathrm{E}+06$ & $4,0 \mathrm{E}+06$ & $4,5 \mathrm{E}+06$ & $5,1 \mathrm{E}+06$ & $5,7 \mathrm{E}+06$ & $6,3 \mathrm{E}+06$ & $6,7 \mathrm{E}+06$ \\
\hline
\end{tabular}


Tabela B.2 Características geométricas e mecânicas da nervura (continuação)

\begin{tabular}{|c|c|c|c|c|c|c|c|c|c|c|c|c|}
\hline \multicolumn{13}{|c|}{ Início de escoamento do aço - tensão $=0,1$ fy } \\
\hline ESCOAM. OU PLASTIF. & ARMAD & ARMAD & ARMAD & ARMAD & CONCR & CONCR & CONCR & CONCR & CONCR & CONCR & CONCR & CONCR \\
\hline My & 303,60 & 596,40 & 882,56 & 1161,74 & 1403,65 & 1574,04 & 1726,95 & 1863,44 & 1983,67 & 2088,04 & 2171,07 & 2230,93 \\
\hline $1 /$ ry & 0,00052 & 0,00055 & 0,00057 & 0,00059 & 0,00057 & 0,00051 & 0,00045 & 0,00042 & 0,00039 & 0,00036 & 0,00035 & 0,00033 \\
\hline Xy & 1,13 & 1,60 & 1,97 & 2,29 & 2,61 & 2,97 & 3,30 & 3,60 & 3,88 & 4,12 & 4,34 & 4,52 \\
\hline TENSAO CONCR. & 1,00 & 1,37 & 1,62 & 1,79 & 1,88 & 1,88 & 1,88 & 1,88 & 1,88 & 1,88 & 1,88 & 1,88 \\
\hline DEF. CONCR. & 0,59 & 0,88 & 1,12 & 1,35 & 1,50 & 1,50 & 1,50 & 1,50 & 1,50 & 1,50 & 1,50 & 1,50 \\
\hline TENSAO As & 60,00 & 60,00 & 60,00 & 60,00 & 58,76 & 55,68 & 53,03 & 50,65 & 48,45 & 46,32 & 44,11 & 41,76 \\
\hline DEF. As & 4,86 & 4,86 & 4,86 & 4,86 & 4,53 & 3,81 & 3,28 & 2,87 & 2,56 & 2,32 & 2,13 & 1,99 \\
\hline RIGIDEZ (2) estádio II & $5,9 \mathrm{E}+05$ & $1,1 \mathrm{E}+06$ & $1,5 \mathrm{E}+06$ & $2,0 \mathrm{E}+06$ & $2,4 \mathrm{E}+06$ & $3,1 \mathrm{E}+06$ & $3,8 \mathrm{E}+06$ & $4,5 \mathrm{E}+06$ & $5,1 \mathrm{E}+06$ & $5,7 \mathrm{E}+06$ & $6,3 \mathrm{E}+06$ & $6,7 \mathrm{E}+06$ \\
\hline MOM. ÚLTIMO & DOM2A & DOM2A & DOM2A & DOM2B & DOM2B & DOM2B & DOM2B & DOM3 & DOM3 & DOM3 & DOM3 & DOM4 \\
\hline $\mathrm{Mu}$ & 306,1 & 604,9 & 895,5 & 1179,3 & 1454,1 & 1720,8 & 1977,6 & 2224,2 & 2460,2 & 2687,6 & 2905,5 & 3091,7 \\
\hline $1 / \mathrm{ru}$ & 0,00103 & 0,00107 & 0,00111 & 0,00115 & 0,00119 & 0,00123 & 0,00127 & 0,00118 & 0,00105 & 0,00094 & 0,00086 & 0,00078 \\
\hline $\mathrm{Xu}$ & 0,82 & 1,19 & 1,50 & 1,78 & 2,06 & 2,34 & 2,63 & 2,97 & 3,34 & 3,71 & 4,08 & 4,49 \\
\hline TENSAO CONCR. & 1,34 & 1,74 & 1,94 & 2,00 & 2,00 & 2,00 & 2,00 & 2,00 & 2,00 & 2,00 & 2,00 & 2,00 \\
\hline DEF. CONCR. & 0,85 & 1,28 & 1,66 & 2,04 & 2,44 & 2,87 & 3,33 & 3,50 & 3,50 & 3,50 & 3,50 & 3,50 \\
\hline TENSAO As & 60,00 & 60,00 & 60,00 & 60,00 & 60,00 & 60,00 & 60,00 & 60,00 & 60,00 & 60,00 & 60,00 & 59,38 \\
\hline DEF. As & 10,00 & 10,00 & 10,00 & 10,00 & 10,00 & 10,00 & 10,00 & 8,89 & 7,52 & 6,42 & 5,51 & 4,69 \\
\hline
\end{tabular}

$A_{S}$ - Área de aço $\left(\mathrm{cm}^{2}\right)$

$X_{I}, X_{I I}$ - posição da linha neutra para os estádios I e II (cm)

$I_{I}, I_{I I}$ - momento de inércia à flexão para os estádios I e II $\left(\mathrm{cm}^{4}\right)$

$M_{r}, M_{y}, M_{u}$ - momento de início de fissuração, de escoamento ou plastificação e último (kN.cm)

Rigidez à flexão estádio II $\left(\mathrm{kN} . \mathrm{cm}^{2}\right)$;

Tensão no concreto e na armadura $\left(\mathrm{kN} / \mathrm{m}^{2}\right)$; Deformação no concreto e na armadura (/1000) 


\section{BIBLIOGRAFIA}

\section{REFERÊNCIAS BIBLIOGRÁFICAS}

ÁLVARES M.S. (1993). Estudo de um modelo de dano para o concreto: formulação, identificação paramétrica e aplicação com o emprego do método dos elementos finitos; São Carlos. Dissertação (Mestrado) Escola de Engenharia de São Carlos, Universidade de São Paulo.

ASSOCIAÇÃO BRASILEIRA DE NORMAS TÉCNICAS (1982). NBR-6118: Projeto e execução de obras de concreto armado. Rio de Janeiro.

ASSOCIAÇÃO BRASILEIRA DE NORMAS TÉCNICAS (1989). NBR-7197: Projeto de estruturas de concreto protendido. Rio de Janeiro.

BARES, R. ; MASSONNET, C. (1966). Le calcul des grillages de poutres et dalles orthotropes. Paris, Dunod Editeor.

BORGES, J.U.A. (1997). Critérios de projeto de lajes nervuradas com vigotas pré-fabricadas. São Paulo. Dissertação (Mestrado) Escola Politécnica da Universidade de São Paulo.

BRANSON D.E. (1963). Instantaneous and time-dependent deflections of simple and continuos reinforced concrete beams. Alabama Highway Department, Bureau of Public Roads. Part 1.(HPR Report n.7). 
CARVALHO, R.C. (1994). Análise não-linear de pavimentos de concreto através da analogia de grelha. São Carlos. Tese ((Doutorado) - Escola de Engenharia de São Carlos , Universidade de São Paulo.

COMITE EURO-INTERNATIONAL DU BETON (1991). CEB-FIP model code 1990. Bulletin d'Information, n.203.

DI PIETRO, J.E. Projeto, execução e produção de lajes com vigotas prémoldadas de concreto. Florianópolis, 1993,99p. Dissertação (Mestrado) - Universidade Federal de Santa Catarina

ESPANHA. Ministério de Fomento (1997). EF-96 - Instruccion para el proyecto y la ejecucion de forjados unidireccionales de hormigon armado o protensado.

ESTUDO experimental da ancoragem de telas soldadas em lajes de concreto (1996). São Carlos, Departamento de Engenharia de Estruturas - Escola de Engenharia de São Carlos, Universidade de São Paulo.

FRANCA, A.B.M ; FUSCO, P.B (1997). As lajes nervuradas na moderna construção de edifícios. São Paulo, AFALA/ABRAPEX.

HAMBLY, E.C. (1991). Bridge deck behavior. 2.ed. London, Chapman and Hall.

LAJES DO FUTURO(1998).Construção, São Paulo, n.2616, p.16-19, março.

LEONHARDT, F.; MÖNNIG, E. (1979). Construções de concreto. Rio de Janeiro, Interciência. v.1.

LEONHARDT, F.; MÖNNIG, E. (1981). Construções de concreto. Rio de Janeiro, Interciência. v.4. 
LIMA, J.C.O. (1993). Sistema treliçado global. 4.ed. Campinas, Mediterrânea. (Boletim técnico).

MUNIZ. C. E. (1991). Mais competitivas: lajes treliçadas. Revista IBRACON, v.1, n.1, p.19-21, julho, agosto.

SANTOS, L. M. (1983). Cálculo de concreto armado. 2.ed. São Paulo, LMS. v.1.

TAKEYA,T. et alii (1985). Recomendações para o projeto e a execução da estrutura em lajes-cogumelo pertencentes à UBS do plano metropolitano de saúde. Relatório. São Carlos, EESC. USP, 31p.

\section{BIBLIOGRAFIA COMPLEMENTAR}

ASSOCIAÇÃO BRASILEIRA DE NORMAS TÉCNICAS (1980). NBR-6120 Cargas para o cálculo de estruturas de edificações. Rio de Janeiro.

BARBOZA, A.S.R. (1992). Contribuição à análise estrutural de sistemas lajes-vigas de concreto armado mediante analogia de grelha. São Carlos. Dissertação (Mestrado) - Escola de Engenharia de São Carlos, Universidade de São Paulo.

BOCHI JR., C.F. (1995). Lajes nervuradas de concreto armado: projeto e execução. São Carlos. Dissertação (Mestrado) - Escola de Engenharia de São Carlos, Universidade de São Paulo.

CAIXETA, P.D. (1998). Contribuição de lajes mistas pré-fabricadas com vigas treliçadas. Campinas. Dissertação (Mestrado) - Faculdade de Engenharia Civil - Universidade Estadual de Campinas.

CORRÊA M.R.S. (1991). Aperfeiçoamento de modelos usualmente empregados no projeto de sistemas estruturais de edifícios. São Carlos. Tese (Doutorado) - Escola de Engenharia de São Carlos, Universidade de São Paulo. 
DINIZ, H. (1988). Lajes com armação em treliça. 2.ed. São Paulo, Vieira de Campos.

ESPANHA. Ministério de Fomento (1988). EF-88 - Instruccion para el proyecto y la ejecucion de forjados unidireccionales de hormigon armado o protensado.

FIGUEIREDO, Filho R.S. (1989). Sistemas estruturais de lajes sem vigas: subsídios para o projeto e execução. São Carlos. Tese (Doutorado) Escola de Engenharia de São Carlos, Universidade de São Paulo.

GASPAR, R. (1997). Análise da segurança estrutural das lajes préfabricadas na fase de construção. São Paulo. Dissertação (Mestrado) - Escola Politécnica da Universidade de São Paulo.

PEREIRA, V. F. (1998) Manual de projeto de lajes pré-moldadas treliçadas. São Paulo, Associação dos fabricantes de laje de São Paulo.

QUIROGA, A.F.S. (1983). Calculo de estructuras de puentes de hormigon. Madrid, Rueda. v.1.

SANCHES, R. F. (1998). Cálculo de esforços e deslocamentos em pavimentos de edifícios, considerando-se modelos próprios para o concreto armado. São Carlos. Dissertação (Mestrado) - Escola de Engenharia de São Carlos, Universidade de São Paulo.

SOUZA, V.C.M. ; DA CUNHA, A.J.P (1994). Lajes em concreto armado e protendido. Niteroi, EDUFF. v.1. 